\title{
LATE CRETACEOUS GEOLOGY OF TARANAKI BASIN, NEW ZEALAND
}

\author{
by \\ Glenn Paul Thrasher
}

Submitted in fullfilment of the requirements

for the degree of

Doctor of Philosophy in Geology

Victoria University of Wellington

1992 


\section{LATE CRETACEOUS GEOLOGY OF TARANAKI BASIN,} NEW ZEALAND

Glenn Paul Thrasher

Victoria University of Wellington, 1992

\section{ABSTRACT}

Taranaki Basin is a large sedimentary basin located along the western side of New Zealand, which contains all of this countries present petroleum production. The basin first formed as the late-Cretaceous Taranaki Rift, and the first widespread sediments are syn-rift deposits associated with this continental rifting. The Taranaki Rift was an obliquely extensional zone which transferred the movement associated with the opening of the New Caledonia Basin southward to the synchronous Tasman Sea oceanic spreading. Along the rift a series of small, en-echelon basins opened, controlled by high-angle normal and strike-slip faults. These small basins presently underlie the much larger Taranaki Basin. Since the initial rift phase, Taranaki Basin has undergone a complex Cenozoic history of subsidence, compression, additional rifting, and minor strike-slip faulting, all usually involving reactivation of the late-Cretaceous rift-controlling faults.

One of the late-Cretaceous rift basins is the Pakawau Basin. Rocks deposited in this basin outcrop in Northwest Nelson as the Pakawau Group. Data from the outcrop and from wells drilled in the basin allow the Pakawau Group to be divided into two formations, the Rakopi Formation and the North Cape Formation, each with recognizable members. The Rakopi Formation (new name) is a sequence of terrestrial strata deposited by fans and meandering streams in an enclosed basin. The North Cape Formation is a transgressive sequence of marine, paralic and coastal-plain strata deposited in response to regional flooding of the rift. The coal-measure strata of the Rakopi Formation are organic rich, and are potential petroleum source rocks where buried deeply enough. In 
contrast, the marine portions of the North Cape Formation contain almost no organic matter and cannot be considered a potential source rock. Sandy facies within both formations have petroleum reservoir potential.

The Rakopi and North Cape formations can be correlated with strata intersected by petroleum exploration wells throughout Taranaki Basin, and all syn-rift sediments can be assigned to them. The Taranaki Rift was initiated about 80 $\mathrm{Ma}$, as recorded by the oldest sediments in the Rakopi Formation. The transgression recorded in the North Cape Formation propagated southwards from about 72 to $70 \mathrm{Ma}$, and the Taranaki Rift remained a large marine embayment until the end of the Cretaceous about 66.5 Ma. Shortly thereafter, a Paleocene regression caused the southern portions of Taranaki Basin to revert to terrestrial (Kapuni Group) sedimentation.

The two distinct late Cretaceous sedimentary sequences of the Rakopi and North Cape formations can be identified on seismic reflection data, and the basal trangressive surface that separates them has been mapped throughout the basin. This horizon essentially marks the end of sedimentation in confined, terrestrial subbasins, and the beginning of Taranaki Basin as a single, continental-margin-related basin. Isopach maps show the Rakopi Formation to be up to $3000 \mathrm{~m}$ thick, and confined to fault- controlled basins. The North Cape Formation is up to $1500 \mathrm{~m}$ thick, and was deposited in a large north-south embayment, open to the New Caledonia basin to the northwest. This embayment was predominantly a shallow-marine feature, with shoreline and lower coastal plain facies deposited around its perimeter. 


\section{ACKNOWLEDGMENTS}

This project was conducted jointly at the Research School of Earth Sciences, Victoria University of Wellington and DSIR Geology \& Geophysics, Lower Hutt. Both organizations provided financial and overhead support.

Project supervision was provided by Dr. J.D. Collen of the Geology Department of the Research School. Additional scientific support was provided by Dr. J.M. Beggs of the Petroleum Section of DSIR Geology \& Geophysics. The scientific guidance and editorial support of both contributed greatly to this thesis.

Numerous individuals at both Victoria University and DSIR Geology \& Geophysics contributed greatly to this project. In particular June Cahill, and Gael Cuttress of DSIR Geology \& Geophysics provided invaluable technical assistance. Mike Wizevich of Victoria University assisted in field work in Northwest Nelson, and provided much sedimentological guidance, especially with the onshore North Cape Formation and the Otimataura Conglomerate. Paleontological examination of numerous samples, and assistance with the interpretation of the results, was provided by Graeme Wilson and Ian Raine of DSIR Geology \& Geophysics. The staff of GECO-NZ, in particular Peter Brown, helped in the production of the maps included as enclosures. The staff of Wiltshire Geological Services supplied digital wireline-log data. Sue Pye provided editorial support.

A long list of people have provided valuable discussions and insights during this project, these include Peter King, Pat Suggate, Simon Nathan, Jim McDougall, Rick Herzer, Richard Sykes, and Richard Cook. A number of people associated with the petroleum exploration industry have also given their support in this project, in particular the exploration staffs of ARCO New Zealand and of Shell Todd Oil Services. All these people are sincerely thanked for their assistance.

Note: All interpreted seismic reflection profiles used in this study are on open file with the Institute of Geological and Nuclear Sciences, Lower Hutt, as Petroleum Report 1795. 


\section{LATE CRETACEOUS GEOLOGY OF TARANAKI BASIN, NEW ZEALAND}

Abstract 2

Acknowledgements 4

Table of Contents 5

List of Figures $\quad 8$

List of Tables 9

List of Enclosures $\quad 10$

1. General information.

1.1 Introduction. 11

1.2 Geological history of Taranaki Basin. 13

1.3 Generalized stratigraphy of Taranaki Basin. 16

1.4 Contributions of the present study. 20

1.5 References. 23

2. Neogene deformation, and the present structural configuration of Taranaki Basin.

2.1 Chapter abstract. 27

2.2 Basin physiography. 28

2.3 Present distribution of syn-rift sediments. 30

2.4 Cenozoic deformation of the basin. 34

2.5 Pre-Neogene disposition of the eastern margin of the basin. 40

2.6 Conclusions. 46

2.7 References. 47

3. Tectonics of the Taranaki Rift.

3.1 Chapter abstract. $\quad 52$

3.2 Introduction. 52

3.3 Late Cretaceous physiography. 53

3.4 Lateral offset across the Taranaki Rift. 58 
3.5 Detachment faulting in the Taranaki Rift.

3.6 Relationship of the Taranaki Rift to the New Caledonia Basin and the Tasman Sea.

3.7 References. 66

4. Geology and petroleum potential of the Pakawau Basin, Northwest Nelson.

4.1 Chapter abstract. 70

4.2 Introduction. 70

4.3 Previous geologic investigations. 73

4.4 Stratigraphy of the Pakawau Basin. 81

4.5 Well and outcrop correlation. 89

4.6 Structure of the Pakawau Basin. 94

4.7 Deformation history. 103

4.8 Sedimentation in the Pakawau Basin. 108

4.9 Petroleum source potential of the Pakawau Basin. 116

4.10 Reservoir potential of the Pakawau Basin. 127

4.11 References.

5. Subsurface geophysical mapping of late Cretaceous sequences, Taranaki Basin.

5.1 Chapter abstract. 139

5.2 Introduction. 140

5.3 Data interpretation. 141

5.4 Depth conversion. 150

5.5 Map production. 155

5.6 Conclusions. 155

5.7 References. 156

6. Subsurface stratigraphy of late Cretaceous rocks, Taranaki Basin.

6.1 Chapter abstract. 158

6.2 Introduction. 159 
6.3 Late Cretaceous stratigraphy of Taranaki Basin. 160

6.4 Well correlation. 165

6.5 Wireline-log correlation. 172

6.6 Chronostratigraphic correlation. 173

6.7 Geochemical correlation. 180

6.8 Conclusions. 185

6.9 References. 187

7. Seismic facies mapping of late Cretaceous sequences, Taranaki Basin.

7.1 Chapter abstract. 193

7.2 Seismic facies mapping. 194

7.3 Lower late-Cretaceous seismic unit. 195

7.4 Upper late-Cretaceous seismic unit. 201

7.5 Seismic reflection evidence for eustatic fluctuations. 209

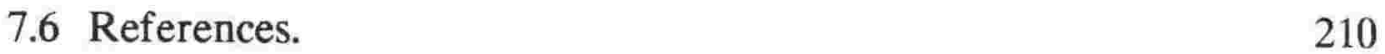

8. Late Cretaceous Paleogeography of Taranaki Basin.

8.1 Chapter abstract. 212

8.2 Introduction. 212

8.3 Late Cretaceous climate. 213

8.4 Paleogeography of the Rakopi Formation. 215

8.5 Paleogeography of the North Cape Formation. 216

8.6 Conclusions. 218

8.7 References. 218

Appendices.

1. Subsurface maps of the Taranaki Basin region, New Zealand. Glenn P. Thrasher and June P. Cahill. New Zealand Geological Survey report G-142, 1990.

2. Unpublished paleontological data used in this study. 
Figures.

1.1 Generalized physiographic diagram, Taranaki Basin. 15

1.2 Generalized stratigraphic diagram, Taranaki Basin. 17

2.1 Location diagram for seismic reflection profiles. 31

2.2 Seismic reflection profile 81-NM-210A. 32

2.3 Seismic reflection profile HF-510. 33

2.4 Neogene deformation, Taranaki Basin. 36

2.5 Seismic reflection profile TNZ-81-619. 39

2.6 Seismic reflection profile HF-18. 42

2.7 Seismic reflection profile P116-81-06. 43

3.1 Wells penetrating late Cretaceous sediments. 54

3.2 Generalized late Cretaceous isopach map. $\quad 56$

3.3 Rose diagram of late Cretaceous fault trends. 59

3.4 Portion of seismic reflection profile TNZ-630. 62

4.1 Generalized geology of Northwest Nelson. 72

4.2 Comparative stratigraphic columns, Northwest Nelson. 75

4.3 Lithologic log of the Rakopi Borehole. 77

4.4 Measured section from the Mangarakau locality. 85

4.5 Geologic cross-section A-A'.

4.6 Geologic cross-section B-B'

4.7 Structural contours on top Eocene, Pakawau Basin. 95

4.8 Structural contours on top Cretaceous, Pakawau Basin. 96

4.9 Structural contours on top Rakopi Formation, Pakawau Basin. 97

4.10 Structural contours on seismic basement, offshore. 98

4.11 Structural contours on basement, Northwest Nelson, onshore. 100

4.12 Paleocene-Eocene Isopach map, Pakawau Basin. 102

4.13 Seismic reflection profile CS-6. 104

4.14 Detail of Seismic reflection profile CS-6. 105

4.15 Lower late-Cretaceous isopach map, Pakawau Basin. $\quad 110$

4.16 Rakopi Formation paleogeography, Pakawau Basin. 111 
4.17 Upper late-Cretaceous isopach map, Pakawau Basin. 112

4.18 Latest Cretaceous paleogeography, Pakawau Basin. 115

4.19 S2 vs. TOC, Cape Farewell-1 well. 119

$4.20 \mathrm{HI}$ vs. OI, Cape Farewell-1 well. 120

4.21 Vitrinite reflectance vs. depth, Cape Farewell-1 well. 124

4.22 Plot of $T_{\max }$ vs. depth, Cape Farewell-1 well. 126

5.1 Seismic reflection profile and well location diagram. 142

5.2 Seismic reflection profile P116-81-20. 144

5.3 Seismic reflection profile HZT-111. 145

5.4 Seismic refleciton profile 81-B-01. 147

5.5 Velocity spectrum, seismic reflection profile, 81-B-01. 149

5.6 Thickness vs. interval-travel-time, lower late-Cretaceous. 153

5.7 Thickness vs. interval-travel-time, upper late-Cretaceous. 154

6.1 Stratigraphy of late Cretaceous sediments. 161

7.1 Rakopi Formation isopach map, Taranaki Basin. 196

7.2 Likely extent, Taniwha Formation, Taranaki Basin. 198

7.3 Rakopi Formation paleogeography, Taranaki Basin. 200

7.4 Block diagram of continental half-graben. 202

7.5 Eustatic sequence, seismic reflection profile 81-B-01. 203

7.6 Mid North Cape Formation paleogeography. 206

7.7 Upper North Cape Formation paleogeography. 207

7.8 North Cape Formation isopach map. 208

Tables.

3.1 Open-file wells intersecting Cretaceous sediments. 55

4.1 Rock-Eval pyrolsis data, Cape Farewell-1. 118

4.2 Rakopi Formation, relative lithologic abundance. 122

5.1 Seismic travel-time data for Cretaceous sediments. 152

6.1 Total-Organic-Carbon data for late Cretaceous sediments. 183 
Enclosures.

2.1 Regional cross-sections.

4.1 Southern Whanganui Inlet well correlations.

5.1 Reflection time isochron on mid late-Cretaceous horizon.

5.2 Isopach of lower late-Cretaceous sediments.

5.3 Isopach of upper late-Cretaceous sediments.

5.4 Structure contours on mid late-Cretaceous horizon.

6.1 Lithostratigrapic well correlation, Taranaki Basin.

6.2 Wireline-log well correlation, Taranaki Basin.

6.3 Chronostratigraphic correlation, Taranaki Basin.

6.4 Geochemical correlation, Taranaki Basin.

A.1 Structural contours on top Eocene.

A.2 Isopach of Cretaceous sediments.

A.3 Structural contours on top Cretaceous.

A.4 Structural contours on seismic basement.

A.5 Well and seismic profile location map. 


\section{CHAPTER 1: GENERAL INFORMATION}

\subsection{Introduction}

This study examines the late Cretaceous tectonic and sedimentary history of Taranaki Basin. Taranaki Basin is a large, mostly offshore, sedimentary basin located along the western side of New Zealand. This basin is moderately well explored for hydrocarbons, with most major structures, both onshore and offshore, having been drilled. In spite of this exploration, the basin's early tectonic and sedimentary history is poorly understood.

The general tectonic model for the formation of Taranaki Basin used by most researchers and petroleum explorers is that expressed by Pilaar and Wakefield in 1978:

\footnotetext{
"Late Cretaceous to Eocene normal block faulting created local fault angle depressions or 'half grabens.' .... This earlier tectonic phase of 'stress controlled' normal faulting ceased prior to the Oligocene and represents the initial rifting and foundering phase of this part of the New Zealand western continental shelf."
}

In 1982, Knox published a benchmark paper on Taranaki Basin in which he identified two Late Cretaceous to early Tertiary fault trends: north-south and northeast-southwest. The northeast-southwest trend he identified as extending southwestwards into the west of the South Island. The details of these trends have continued to elude explorers, however, because of the thickness of sedimentary cover, poor seismic reflection data, and lack of stratigraphic control from within the deeper portions of the basin.

By 1988 the concept of a distinct late Cretaceous history for Taranaki Basin was beginning to appear in scientific literature. King and Robinson (1988) published 
a series of paleogeographic maps for the basin, including one for the "latest Cretaceous (65 Ma)", showing the basin as a large, north-facing embayment with a few large north-south elongated, fault-controlled islands. The overall structure was one of "basement grabens and depressions due to crustal attenuation and/or cooling" along the margins of Tasman Sea rifting. The details of this tectonism were sketchy, however. The first detailed study of the Cretaceous tectonics of Taranaki Basin was presented by Thrasher (1990), and forms part of the research reported in this study.

The investigation of early-basin sedimentation followed a similar history to that of the tectonics. Initially the late Cretaceous was believed to be composed entirely of terrestrial Pakawau Group sediments resting on an eroded basement. The discussions of Pilaar and Wakefield (1978), Knox (1982), Palmer (1985), Nathan and others (1986) and Shell Oil Company (1987) are all based on this "coal measure" assumption. During the 1980's, however, a few exploration wells in the basin intersected marine sediments of late Cretaceous age. This was noted by both Purcell (1986) and King and Robinson (1988) as indicating a late Cretaceous marine transgression into the basin. Also in 1988, King proposed the name "Tahi Group" for these late Cretaceous marine sediments. However, the distribution and sedimentary environments of the Pakawau and Tahi groups were not investigated in any detail.

The hydrocarbons discovered to date within Taranaki Basin were shown by Cook (1987) to have a terrestrial organic origin. Johnston and others (1989) suggested the most likely source rocks in the basin were the deeply buried terrestrial rocks of the late Cretaceous Pakawau Group. These syn-rift rocks also exhibit structure, reservoir and trap characteristics worthy of consideration for future exploration. The examination of the rifting history of the basin, and the syn-rift sedimentation, is an important step in the exploration of the basin. 


\subsection{Geological history of Taranaki Basin}

Taranaki Basin is a large sedimentary basin located along the western side of New Zealand. The basin is mostly offshore, and underlies much of the continental shelf west of the North Island. New Zealand's only commercial discoveries of hydrocarbons have been within this basin. Because Taranaki Basin is almost entirely a subsurface feature, the history of geologic knowledge of the area is short, although rudimentary exploration began last century and hydrocarbon production in the basin has been continuous since 1866 (Katz 1988). Modern knowledge of the basin really begins with the 1955 discovery of the Kapuni Field, on the southern side of the Taranaki Peninsula. This discovery proved the basin to contain sediments as old as Eocene, and as thick as $3.5 \mathrm{~km}$. The basin was formally named in 1967, in an article by Cope and Reed which stated:

\footnotetext{
"West of the Taranaki Fault, Eocene (or older) sediments rest on basement and they are overlain by an almost complete succession of Cenozoic deposits up to the Recent Egmont Volcanics. The term Taranaki Basin is proposed for this sedimentation area covering the peninsular part of the Province. Based on the present interpretation, this basin probably extends beneath the North and South Taranaki Bights but the western boundary is as yet unknown."
}

The acquisition of considerable seismic reflection data since that 1967 article has allowed subsurface mapping of the basin (for example, Shell Oil Company 1987, Thrasher and Cahill 1990). Taranaki Basin is now known to be a predominantly north-south subsurface feature. The present basin is bounded to the east by the Taranaki Fault, a major late-Paleogene to Neogene reverse fault which vertically offsets basement by more than five kilometres. To the west the basement gradually shallows onto the Challenger Plateau, an oceanic 
bathymetric high. The northern and southern limits of the basin are not clearly defined. To the south the basin merges with the numerous small basins of the northwestern South Island, while to the northwest it merges with the bathyal New Caledonia Basin.

The present study will show that the basin first formed as a late Cretaceous transcurrent rift along the Gondwanaland margin. This eastern edge of Gondwanaland was a belt of terranes accreted during Mesozoic convergent tectonics (Sporli 1987, Bradshaw 1989). Following this initial rifting, subsidence continued throughout the Cretaceous and into the early Tertiary. Since the rift phase, the basin has undergone a complex history of subsidence, compression and additional extension. This post-rifting period has been documented by King and Thrasher (in press). Major physiographic features of the basin are shown on Figure 1.1.

Post-rift tectonic activity in the basin began in the late-Oligocene, when a dramatic increase in subsidence in the eastern portions of the basin is documented. This subsidence is believed to have been foreland basin development associated with transpression along the Taranaki Fault Zone (King and Thrasher in press). Basement on the eastern side of the fault overthrust basin sediments during the Miocene, to form the eastern margin of the basin. The amount of shortening associated with this thrust is unknown, and is one of the more interesting problems of Taranaki Basin geology. Associated with westdirected thrusting of basement across the Taranaki Fault are thin-skinned overthrusts soling within the Paleogene section (Hoolihan and Yang 1991, King and Thrasher in press). These "sled-runner" structures have been a major exploration target of the last decade.

About $10 \mathrm{Ma}$, the region of major compression shifted south, and the "Southern Zone" became a region of major structural inversion of older normal faults. Many of the most spectacular anticlinal features in the basin were formed by this compression during the last 10 million years. The compression led to 


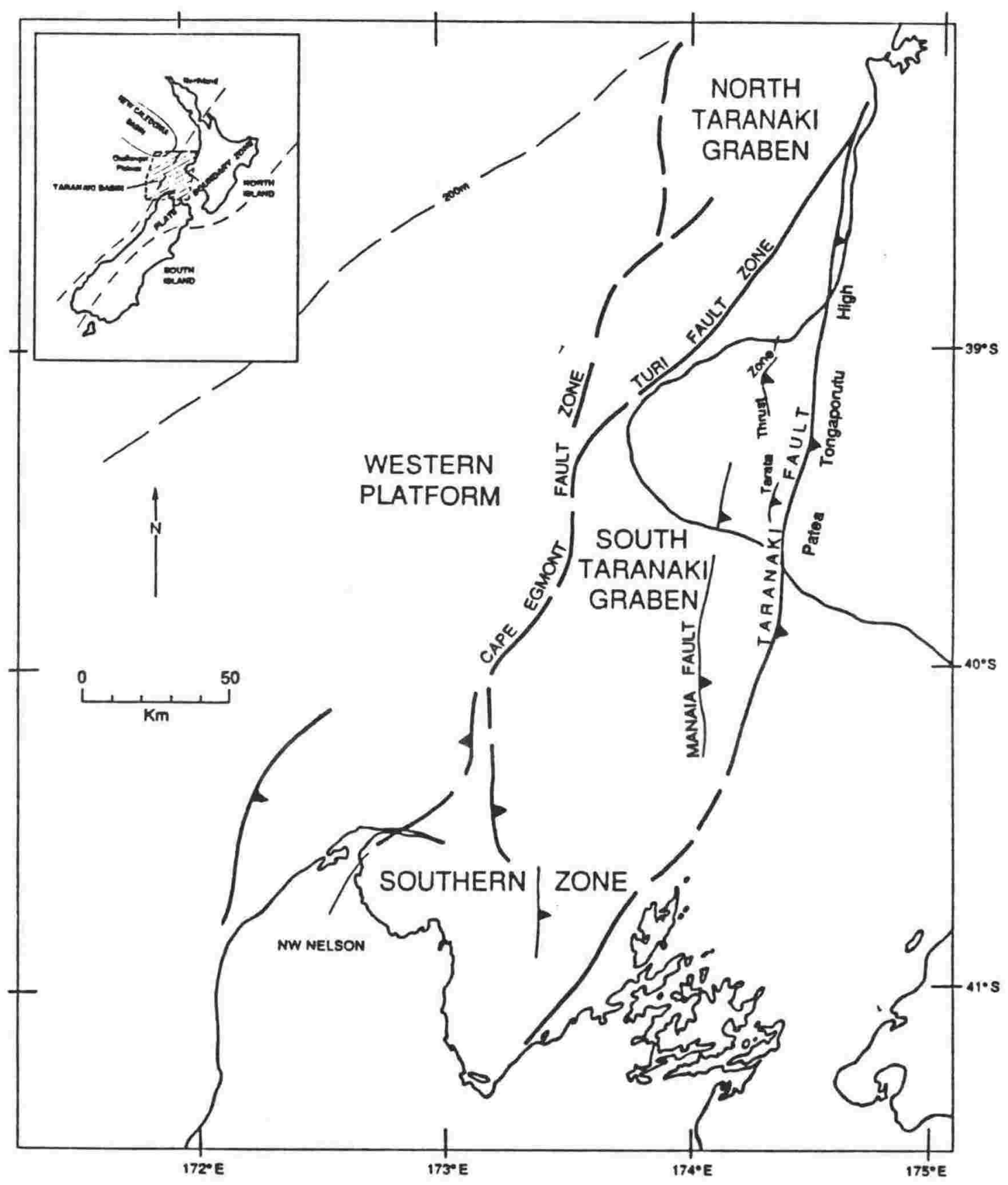

Figure 1.1 Generalized physiographic diagram, Taranaki Basin. After King and Thrasher (in press). 
considerable uplift and erosion in the south, and a subsequent increase in sedimentation in the northern and western portions of the basin. The same period has hence been one of very high sedimentation rates, which have caused the progradation of the continental shelf to the northwest as a series of giant, clinoform-bounded, sediment wedges.

Complicating this pattern of uplift, erosion and progradation has been the subsidence of the North and South Taranaki grabens due to back-arc rifting (with associated volcanism) and flexure. The present configuration of the basin, which is dominated by the stable Western Platform, the subsiding Taranaki Graben, and the Taranaki Fault Zone, is a combined result of the tectonic processes of the last 100 million years. However, the architecture of the basin is in large part controlled by the tectonic trends of the late Cretaceous rift phase.

\subsection{Generalized stratigraphy of Taranaki Basin}

Several authors have reviewed the general stratigraphy of Taranaki Basin in recent years. The most significant of these are Pilaar and Wakefield (1978), Knox (1982), Palmer (1985), King and Robinson (1988), King (1988), and King and Thrasher (in press). Each of these compilations was based on an updating of previous authors, taking into account the results of more recent drilling. Because Taranaki Basin is a large area (about $100,000 \mathrm{~km}^{2}$ ) with a complicated structural history, the lateral variability in sedimentary environments requires a complex stratigraphic system. The post-Cretaceous stratigraphic nomenclature used in the present study is adapted from that of King and Thrasher (in press). That stratigraphic nomenclature is summarized in Figure 1.2. The present study attempts to clarify the Cretaceous portion of this stratigraphic system, but there is potential for further rationalization, especially in the Paleocene and Eocene. 


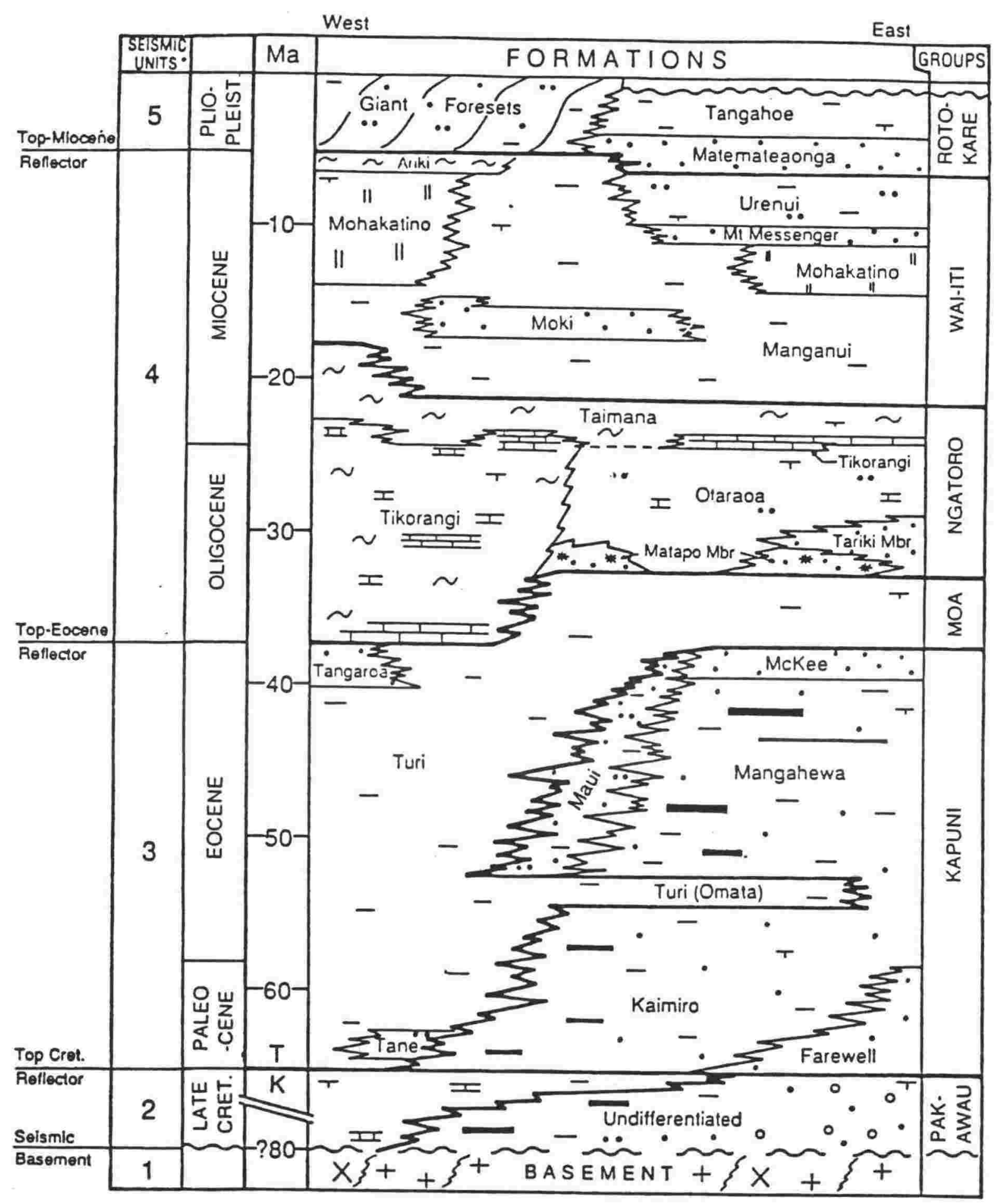

Figure 1.2 Taranaki Basin stratigraphic column (adapted from King and Thrasher in press). Cretaceous stratigraphy is refined in Ch. 6.

* See text for description of numbered seismic units. 
The composition of basement underlying Taranaki Basin sedimentary sequences is poorly known. Because the sedimentary cover on basement is very thick, up to $9 \mathrm{~km}$, the only information on basement rock type is from sparse onshore outcrops around the periphery of the basin, from the exploration wells that have reached basement, and inference from sesimic reflection, magnetic and gravity data. In general, the subsurface distribution of basement rock types proposed by Wodzicki (1974) has been confirmed by more recent studies (Mortimer and others 1991). The Taranaki Fault Zone appears to be a crustal contact between basement rocks with an upper-crustal, late Palaeozoic to Jurassic, metasedimentary origin on the eastern side and lower-crustal, mainly Palaeozoic, Gondwana continental rocks to the west (Mills 1991). Therefore, basement under Taranaki Basin is generally expected to be igneous and higher-grade metamorphic rocks (Thrasher 1990).

Taranaki Basin sedimentation can be subdivided into four main phases. The first phase is the late Cretaceous and Paleocene rifting, and associated transgression. The late Cretaceous portion of this phase is represented by the Pakawau Group, which includes terrestrial and transgressive marine sedimentary rocks, and is the focus of the present study.

The second sedimentary phase within Taranaki Basin is the Paleocene and Eocene transgressive sequence deposited in response to regional post-rift subsidence. This phase is represented by the terrestrial Kapuni Group and its marine equivalent, the Moa Group. By the end of the Eocene the fine-grained, terrigenous sediments of the Moa Group covered most of the basin, and the physiography of the rift no longer controlled sedimentation to any significant degree.

The culmination of this inundation, combined with renewed tectonic subsidence during the Oligocene, resulted in the third sedimentary phase, represented by the Ngatoro Group carbonate deposition. The basin was largely submerged, with substantial portions at bathyal depths. The Ngatoro Group tends to be 
thin, except in the more proximal, eastern portions of the basin where coarse shelf carbonates were deposited.

The fourth sedimentary phase is the regressive progradation of the shelf across the basin in the Neogene. This phase is represented by the marine, terrigenous deposits of the Wai-iti Group and the overlying Rotokare Group, whose strata form a thick sequence of fine-grained rocks over much of the basin. The division between the Wai-iti and Rotokare groups is based on a widespread unconformity which resulted from a significant change in tectonic style. The Rotokare Group had much the higher sedimentation rate of the two; it represents only the last five million years of the basin's history, but can be greater than two kilometres thick.

Thrasher (1988) proposed a system for seismic reflection mapping in the basin based on the stratigraphy outlined above. He proposed four basin-wide reflectors for subsurface mapping, and five seismic-stratigraphic units. In that system the reflectors, which are illustrated on the stratigraphic column of figure 1.2, are: seismic basement; top Cretaceous (top Pakawau Group); top Eocene (approximately base Ngatoro Group); and top Miocene (unconformity between the Wai-iti Group and the Rotokare Group).

This sequence of reflectors divides the stratigraphy into 5 seismic stratigraphic units (noted on Figure 1.2) as follows:

1. Pre-late Cretaceous basement.

2. Late-Cretaceous rift-controlled sediments.

3. Paleocene-Eocene regional transgressive sediments.

4. Oligocene-Miocene hiatal and regressive sediments.

5. Pliocene-Pleistocene regressive sediments.

These seismic reflectors and units are based in large part on the accumulated experience of several years of seismic reflection mapping in Taranaki Basin by 
numerous petroleum and government researchers. In particular the Shell, BP and Todd consortium were instrumental in formulating a seismic stratigraphic system which is applicable throughout the basin (for example, Shell Oil Company 1987). The subsurface maps of the basin prepared by Thrasher and Cahill (1990), which provide the framework for the present study, were prepared using these seismically defined units.

\subsection{Contributions of the present study}

Because Taranaki Basin has had a history of petroleum exploration, the basin is now covered by a grid of seismic reflection profiles and has been penetrated by many petroleum exploration wells. New Zealand law requires that the results of all petroleum exploration, including seismic and well results, be lodged with the New Zealand Government. These data become available to the public once a period of confidentiality, at most 5 years, expires. Petroleum exploration data is curated and released to the public by DSIR Geology \& Geophysics, as "Petroleum Reports" (PR's).

The initial phase of the project of which the present study is part involved the interpretation of a large volume of seismic reflection data, under the close supervision of the author, by the staff of the New Zealand Geological Survey (now DSIR Geology \& Geophysics). This interpretation made use of 22,000 line kilometres of seismic reflection data, and was tied to 47 open-file petroleum exploration wells in the basin. Details of the interpretation methods used, including identification of reflectors, depth conversion, and preparation of final maps are presented as Appendix 1: Subsurface maps of the Taranaki Basin, New Zealand, by Thrasher and Cahill (1990). 
The maps produced as a part of Thrasher and Cahill which are of immediate interest in understanding late Cretaceous tectonics and sedimentation are included as enclosures A.1 to A.5. These maps are:

A.1 Structural contours on top Eocene.

A.2 Isopach of Cretaceous sediments.

A.3 Structural contours on top Cretaceous.

A.4 Structural contours on seismic basement.

A.5 Well and seismic profile location map.

This study makes extensive use of these subsurface maps. It is important that readers be familiar with the methods used in this mapping, and with the various seismic horizons interpreted throughout the basin. Therefore, readers are recommended to familiarize themselves with Appendix 1, and the corresponding maps.

The mapping discussed above identified regions where late Cretaceous sedimentary rocks are present in the basin (Enclosure A.2). Chapter 2 of the present study examines the structural configuration of Taranaki Basin and determines that the distribution of late Cretaceous rocks has not been significantly altered since deposition. Therefore, study of their present distribution will provide details of the late Cretaceous tectonic and sedimentary history of the basin.

In Chapter 3 the present distribution of late Cretaceous rocks is examined to ascertain the tectonic controls on late Cretaceous sedimentation, and to develop a model for the formation of the Taranaki Rift. This rift was an obliquely extensional zone which transferred the opening of the New Caledonia Basin through the present Taranaki Basin and along the west coast of the South Island. The transcurrent motion formed the series of en echelon basins which presently underlie Taranaki Basin. 
Portions of one of these basins, the Pakawau Basin, outcrop in the Pakawau region of Northwest Nelson. This outcrop, and the subsurface portions of the Pakawau Basin, are examined in Chapter 4, as a model of late Cretaceous, riftcontrolled sedimentation. In Chapter 4, the Pakawau Basin is shown to have a two-part sedimentary history: the lower late-Cretaceous rocks in the basin were deposited in a terrestrial environment, and have high organic contents; whereas the upper late-Cretaceous rocks in the basin were deposited in a marine to paralic environment, and are very poor in organic material. This twopart stratigraphy is interpretable throughout the Pakawau Basin, including the subsurface and offshore portions. Offshore, both petroleum exploration wells and seismic reflection data record the late Cretaceous transgression which resulted in this two-part stratigraphy.

The subdivision of the late Cretaceous sedimentary sequence into two seismically mappable units represents an important contribution to the knowledge of Taranaki Basin. Chapter 5 of the present study presents a Taranaki Basin-wide seismic-reflection interpretation of the two seismic reflection units documented in the Pakawau Basin. This interpretation utilizes the same data set and methods as the seismic reflection maps introduced above.

Chapter 6 documents the subsurface stratigraphy of the late Cretaceous rocks of Taranaki Basin. This chapter uses lithologic, paleontologic, wireline log, and geochemical data from petroleum exploration wells to detail the stratigraphy of the two seismic reflection units mapped in Chapter 5. The two-part stratigraphy documented for the Pakawau Basin is shown to be present throughout the series of late Cretaceous basins underlying Taranaki Basin. The lower seismic unit corresponds to terrestrial sedimentation, while the upper seismic unit corresponds to marine and paralic sedimentation. Several distinct depositional environments, ranging from terrestrial debris-fans to marine shelf deposits, can be determined from the well data. 
In Chapter 7, the techniques of seismic facies mapping are utilized to develop paleogeographic maps of the Taranaki Basin at three times during the late Cretaceous. In particular, the marine transgression which flooded the rift system during the latest Cretaceous is documented, as are eustatic cycles. Chapter 8 provides further evidence on the paleogeography of the Taranaki Rift, and on late Cretaceous climate, as well as concluding remarks.

Each chapter is intended to cover a single topic, and be essentially independent of other chapters; thus each chapter has an independent abstract and reference list. Although some references are listed in more than one chapter, for the most part the chapters refer to substantially different literature. However, to avoid redundant figures, many figures appear only once, but are cross-referenced in later chapters.

This study provides documentation on the process of rifting of a continental margin, on the response of a depositional system to the drowning of a continental rift, and on the possible relationship of the New Caledonia Basin to the opening of the Tasman Sea. Such study of continental rifting is only possible because of the large amount of petroleum exploration data available from the basin, and the implications of these observations to petroleum exploration in Taranaki Basin are discussed.

\subsection{References}

Bradshaw, J.D. 1989: Cretaceous geotectonic patterns in the New Zealand region. Tectonics $8(4): 803-820$.

Cook, R.A. 1987: The geology and geochemistry of the crude oils and source rocks of western New Zealand, PhD thesis, Victoria University of Wellington. 
Cope, R.N.; Reed, J.J. 1967: The Cretaceous paleogeology of the Taranaki-Cook Strait area. Australasian Institute of Mining and Metallurgy Proceedings, No. 222: 63-72.

Hoolihan, K.; Yang, J. 1991: Eocene to Recent structural history of onshore Taranaki, with reference to the main play styles. Programme and Abstracts, 1991 New Zealand Oil Exploration Conference: 36.

Johnston, J.H.; Collier, R.J.; Collen, J.D. 1989: Where is the source for the Taranaki Basin oils? Geochemical markers suggest it is the very deep coals and shales. In: Ministry of Commerce (1990), 1989 New Zealand Oil Exploration Conference Proceedings: 288-296.

Katz, H.R. 1988: A historical review of petroleum exploration in New Zealand. Energy Exploration and Exploitation 6(2): 89-103.

King, P.R. 1988: Well summary Sheets, offshore Taranaki. New Zealand Geological Survey Report G127.

King, P.R.; Robinson, P.H. 1988: An overview of Taranaki region geology, New Zealand. Energy Exploration and Exploitation 6(3): 213-232.

King, P.R.; Thrasher, G.P. (in press): Post-Eocene development of the Taranaki Basin, New Zealand: convergent overprint of a passive margin. American Association of Petroleum Geologists memoir 53, chapter 11.

Knox, G.J. 1982: Taranaki Basin, structural style and tectonic setting. New Zealand Journal of Geology and Geophysics 25(2): 125-140.

Mills, C. 1990: Gravity expression of the Patea-Tongaporutu High and subsequent model for the Taranaki Basin margin. In: Ministry of Commerce (1990), 1989 New Zealand Oil Exploration Conference Proceedings: 191-200. 
Mortimer, N.; Beggs, J.M.; Davy, B.; Tulloch, A.J.; Thrasher, G.P. 1991: Geometry of basement terranes beneath the Taranaki and Wanganui Basins. Abstract in: Geological Society of New Zealand miscellaneous publications 59A.

Nathan, S.; Anderson, H.J.; Cook, R.A.; Herzer, R.H.; Hoskins, R.H.; Raine, J.I.; Smale, D. 1986: Cretaceous and Cenozoic sedimentary basins of the West Coast region, South Island, New Zealand. New Zealand Geological Survey basin studies 1 .

Palmer, J.A. 1985: Pre-Miocene lithostratigraphy of Taranaki Basin, New Zealand. New Zealand Journal of Geology and Geophysics 28(2): 197-216.

Pilaar, W.F.H.; Wakefield, L.L. 1978: Structural and stratigraphic evolution of the Taranaki Basin, offshore North Island, New Zealand. The APEA Journal, Vol. 10: 93-101.

Purcell, P.G. 1986: The coal basins of Western New Zealand--an introduction. In: Glenie, R.C. (ed.) Proceedings of the second south-eastern Australia oil exploration symposium. Petroleum Exploration Society of Australia: 319-330.

Shell Oil Company 1987: Seismic sequences as applied to basin- fill analysis: Taranaki Basin, New Zealand. In: Bally, A.W. (ed.): Atlas of seismic stratigraphy. American Association of Petroleum Geologists, Studies in geology No. 27: 53-71.

Sporli, K.B. 1987: Development of the New Zealand microcontinent. In: J. Monger, J. Franchateau (eds): Circum-Pacific orogenic belts and the evolution of the Pacific Ocean basin. American Geophysical Union, Geodynamics Series, Vol. 18: 115-132. 
Thrasher, G.P. 1988: The interpretation of seismic reflection data from the Western Platform region of Taranaki Basin. Energy Exploration and Exploitation 6(2): 136-150.

Thrasher, G.P. 1990: Tectonics of the Taranaki Rift. In: Ministry of Commerce (1990), 1989 New Zealand Oil Exploration Conference Proceedings: 124-133.

Thrasher, G.P.; Cahill, J.P. 1990: Subsurface maps of the Taranaki Basin region, New Zealand. New Zealand Geological Survey report G-142 (copy in Appendix 1)

Wodzicki, A. 1974: Geology of the pre-Cenozoic basement of the Taranaki-Cook Strait-Westland area, New Zealand, based on recent drillhole data. New Zealand Journal of Geology and Geophysics 17(4): 747-757. 
CHAPTER 2: $\quad$ NEOGENE DEFORMATION, AND THE PRESENT STRUCTURAL CONFIGURATION OF TARANAKI BASIN

\subsection{Chapter abstract}

Taranaki Basin can be subdivided into five physiographic units, each with a distinctive structural style and history. Although the Western Platform has undergone no significant internal deformation since the cessation of rifting in the region at about the end of the Cretaceous, the North and South Taranaki grabens are regions of Tertiary extension and the Southern Zone is a region of Tertiary shortening. The Eastern Taranaki High is a large basement ridge forming the eastern edge of the basin.

Neogene dip-slip motion of a few kilometres along the major fault systems in the basin accounts for the deformation associated with the formation of the North Taranaki Graben, South Taranaki Graben, and Southern Zone. Less than $5 \mathrm{~km}$ of extension is required for the formation of the two grabens, and a similar amount of shortening is required for the deformation observed in the Southern Zone. The Cape Egmont Fault Zone has undergone some dextral wrench motion during the Neogene, but only a few kilometres of lateral motion is indicated by the observed fault patterns.

The Taranaki Fault Zone, along the eastern margin of the basin, may have accommodated some dip-slip and wrench motion, but the nature and magnitude of this motion is difficult to estimate. Today this fault marks the abrupt and absolute edge of the basin. There is little evidence that the basin was ever much larger than it is today, and the pre-Neogene eastern margin of the basin was probably steep, and near the present Eastern Taranaki High. 
Because the observed deformation within the basin is small (a few kilometres) compared with the dimensions of the basin (hundreds of kilometres), the present distribution of late Cretaceous, syn-rift sequences can be taken as approximating their original distribution. Therefore, the study of the nature and present distribution of those sequences in order to understand the early history of the basin is justified.

\subsection{Basin physiography}

Taranaki Basin is generally subdivided into four structural units. Following general usage, King and Robinson (1988) labelled these four units Western Platform, Southern Zone, Northern Taranaki Graben, and Southern Taranaki Graben (Figure 1.1). A fifth structural unit is necessary to fully describe the structural configuration of the basin: the subsurface basement high which bounds the eastern edge of the basin. Various names for this block are in common usage along its length. North of the Taranaki Peninsula it is often called the Herangi High. Onshore along the eastern side of the peninsula it is referred to as the Patea-Tongaporutu High. South of the peninsula, Anderton (1981) referred to the feature as the D'Urville High. In the present study, it will be referred to as the "Eastern Taranaki High".

Enclosure 2.1 displays three structural cross-sections through the basin. The first is across the northern part of the study area, extending from the Challenger Plateau, across the Western Platform and Northern Taranaki Graben and onto the Eastern Taranaki High. The second crosses the central part of the study area, extending from the Challenger Plateau across the Western Platform and Southern Taranaki Graben and onto the Eastern Basement High. The final one crosses the southern part of the study area, extending from the Western Platform across the Southern Zone and onto the Eastern Taranaki High. 
The Western Platform is a broad region of relatively simple structure which has been tectonically quiescent since the end of the Cretaceous. This contrasts markedly with the Southern Zone, where post-Oligocene compression has resulted in the reactivation of rift-related normal faults to form a series of eversion anticlines truncated by a widespread angular unconformity. The Southern Taranaki Graben is an area of Pliocene through Pleistocene crustal downwarp and down-to-the-east normal faulting, probably linked closely with the formation of the Southern Wanganui Basin (King and Thrasher in press). The Northern Taranaki Graben is a region of late-Miocene through Pliocene extension, with related middle- to late-Miocene volcanism.

Two major fault zones control the present structure in the basin: the Cape Egmont Fault Zone and the Taranaki Fault Zone. The Cape Egmont Fault Zone is a system of en echelon faults extending from about $40^{\circ} \mathrm{S}$, south of the Maui Field, to beyond the northern edge of the study area $\left(38^{\circ} \mathrm{S}\right)$. South of this, the Western Platform is separated from the Southern Zone by a series of mainly reverse faults, with up to $2500 \mathrm{~m}$ of reverse motion. In the north, where the Cape Egmont Fault Zone separates the Western Platform from the Northern and Southern Taranaki grabens, the faults are all normal, with up to $2000 \mathrm{~m}$ of down-to-the-east throw. These relationships are most easily observed at the top-Eocene structural level (Enclosure A.1). The Cape Egmont Fault Zone is discussed in more detail in Section 2.4.

The mainly-Miocene Taranaki Fault Zone separates the basin from the Eastern Basement High. This fault zone is actually a continuous fault for most of the $400 \mathrm{~km}$ length of the basin, and only in the southern regions does it display any en echelon character. Section 2.5 includes a more detailed discussion of the Taranaki Fault Zone.

The aim of this study is to investigate the tectonic and sedimentary history of the syn-rift sequences within Taranaki Basin. The only source of information readily available to do this is the present distribution and configuration of these 
rocks. Therefore, it is necessary to ascertain the extent of post-rift removal, deformation and translation of the late-Cretaceous sedimentary sequence.

\subsection{Present distribution of syn-rift sediments}

Throughout the basin the syn-rift rock sequence is in normal sedimentary contact with the underlying basement rocks, and onlaps basement highs. The transition from syn-rift to post-rift sedimentation is conformable almost everywhere, with immediate post-rift sediments overtopping most residual basement highs. In two major regions of the basin the transition from syn-rift to post-rift sedimentation is not a normal sedimentary progression: in Northwest Nelson, where the Pakawau Subbasin has been uplifted, unroofed, and is today exposed; and in the southern end of the Manaia Anticline, where the syn-rift sequence was uplifted and exposed during the Miocene, and is now unconformably overlain with Pliocene and Pleistocene sediments.

Enclosure A.2 is an isopach map of the Cretaceous sedimentary sequence. Cretaceous strata are shown to be in two depositional settings: firstly, as a thin (generally less than $1000 \mathrm{~m}$ ) unit underlying much of the western portion of the basin (Figure 2.2 illustrates this setting), and, secondly, as much thicker (up to $4000 \mathrm{~m}$ ) deposits in isolated, fault-controlled, subbasins (Figure 2.3).

Seismic interpretation suggests that fault-controlled sedimentation continued into the Paleocene in two settings: firstly, many of the faults controlling very thick accumulations of Cretaceous sediments continued to be active, probably due to differential compaction of underlying syn-rift sediments, allowing for localized Paleocene depocentres (Figure 2.3); secondly, extension, with concurrent subsidence, continued along the eastern side of the basin and gave rise to thick, syn-rift sedimentation along the Manaia trend in the Paleocene. 


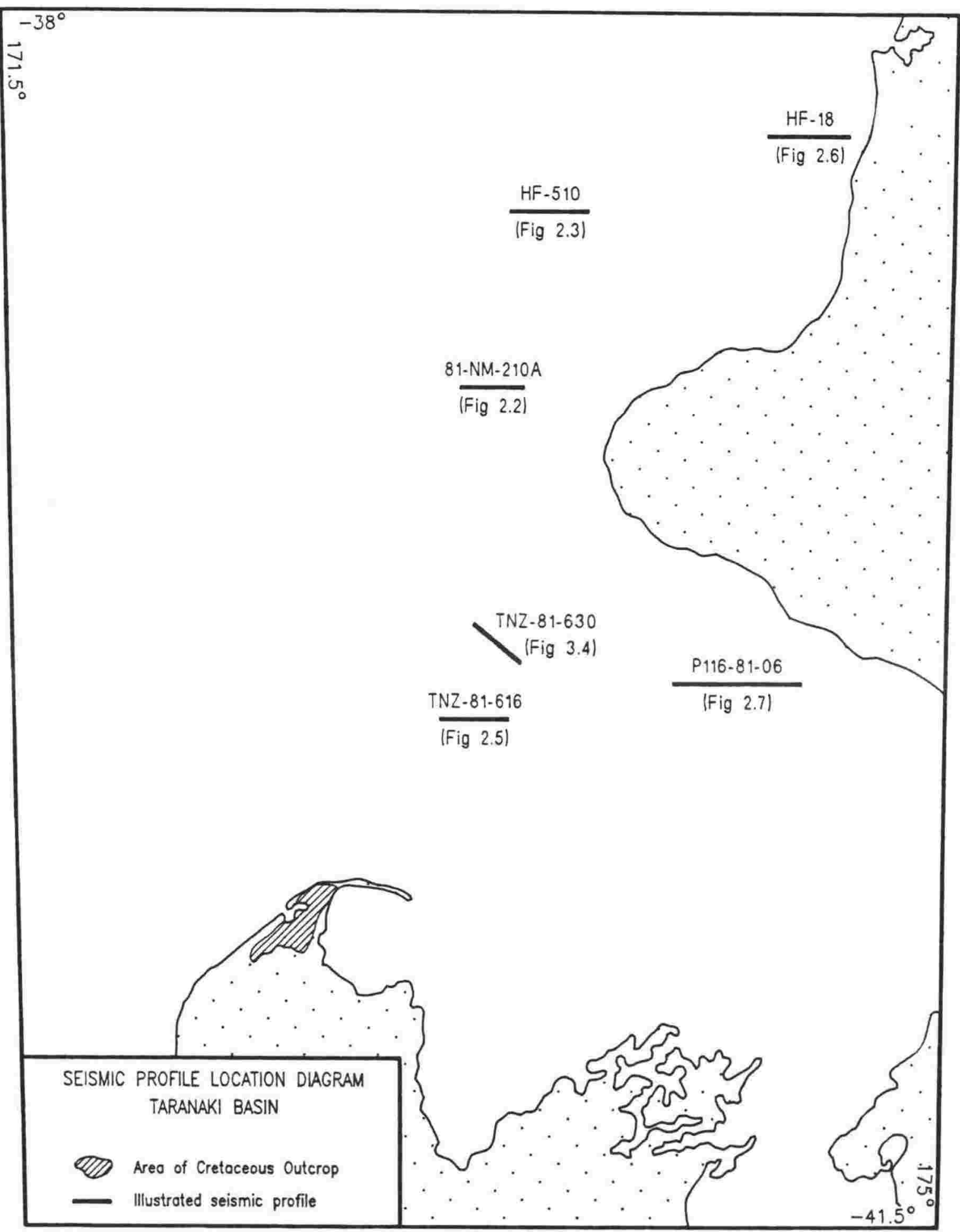

Figure 2.1 Location diagram for seismic reflection profiles illustrated in chapters 2 and 3. 


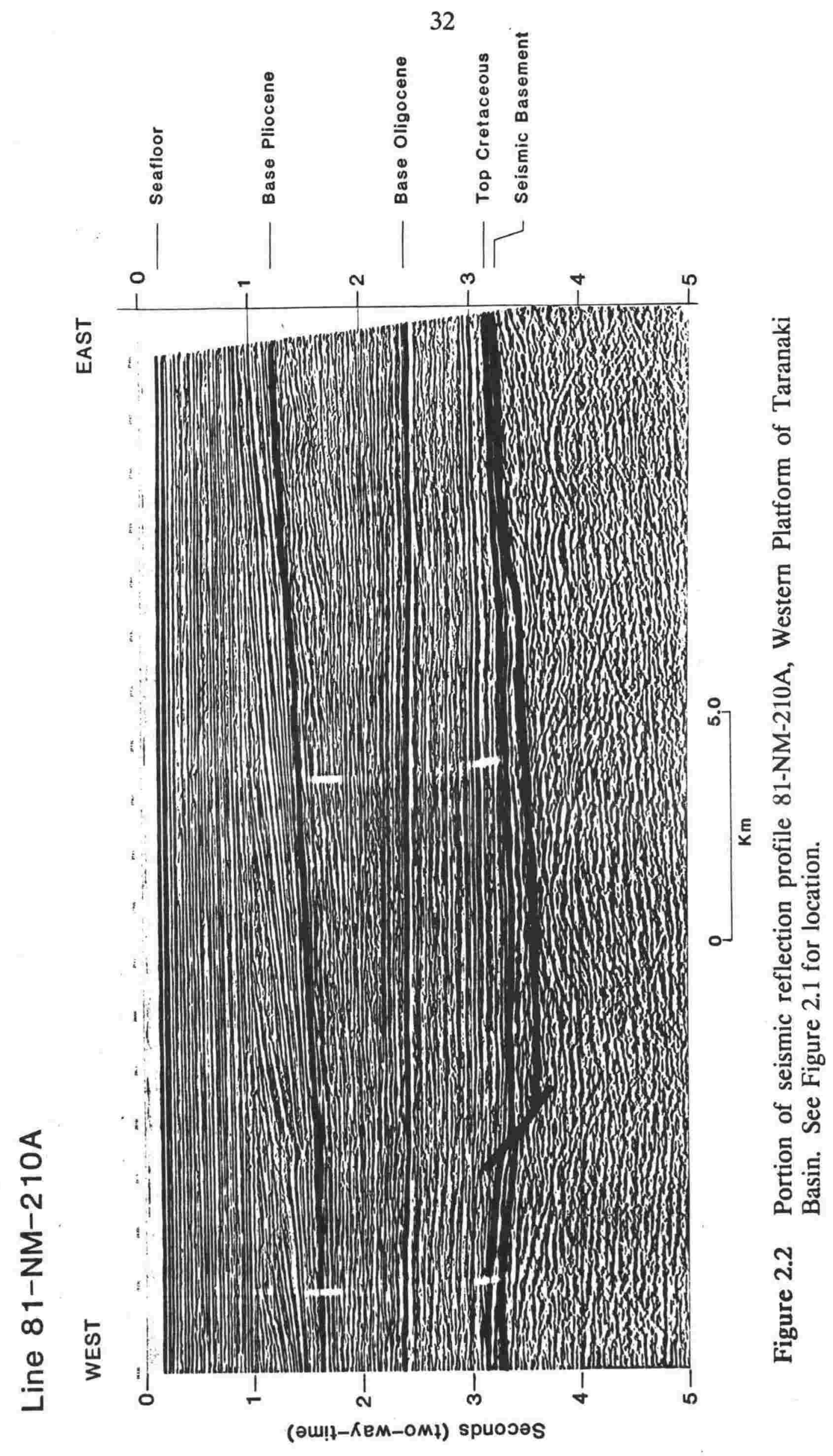




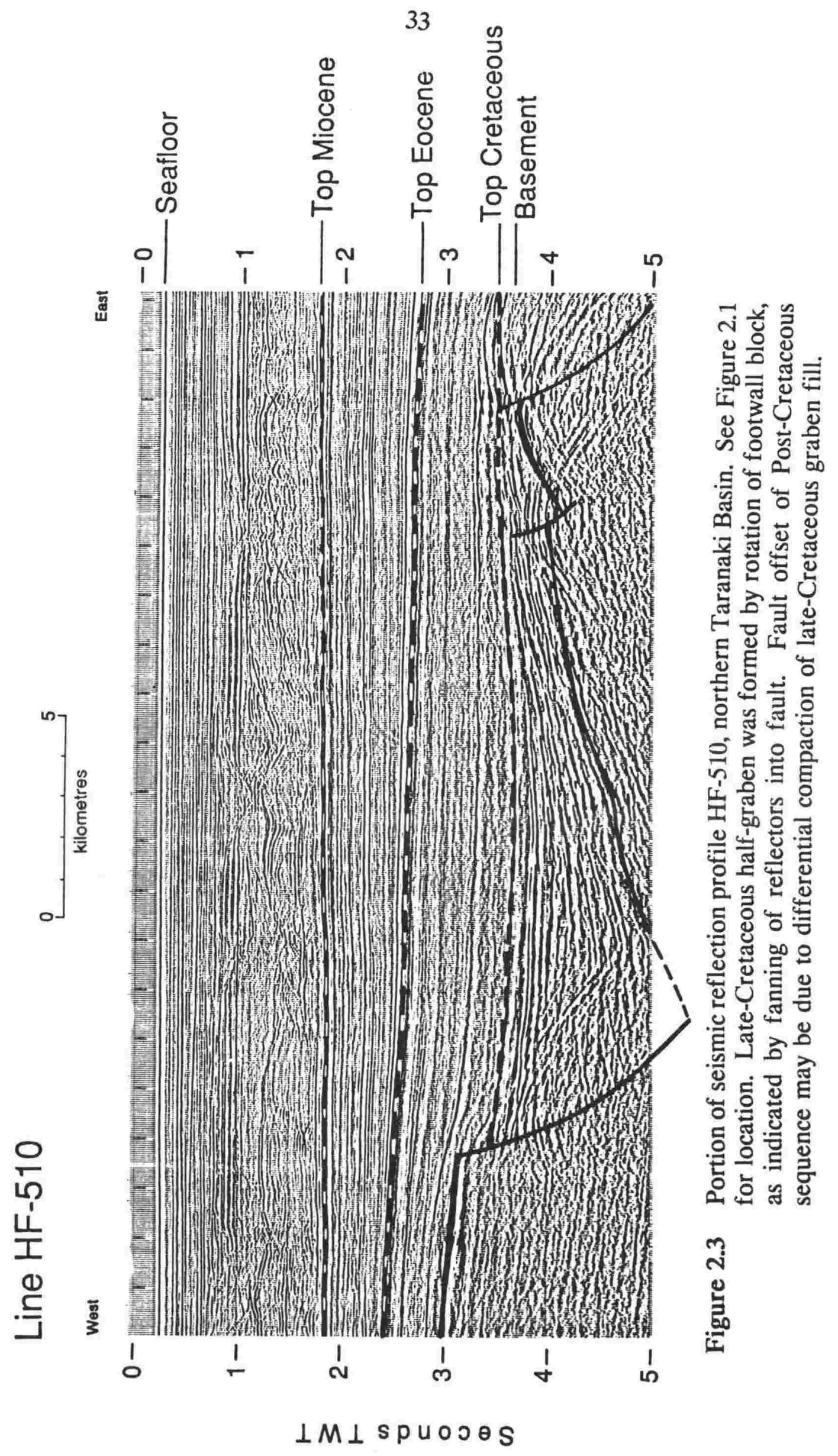




\subsection{Cenozoic deformation of the basin}

King and Thrasher (in press) demonstrate that following initial rifting the Taranaki Basin developed throughout the Paleogene as a passive margin, and that most post-rift deformation in the basin has occurred in the Neogene. Examination of the Neogene deformation can therefore indicate the amount of post-depositional deformation that the syn-rift sedimentary sequence has been subjected to. The top-Eocene seismic marker has been mapped throughout the basin (see Appendix 1 and Enclosure A.1), and makes a convenient horizon to use in estimating post-Eocene deformation.

On Enclosure A.1, the top-Eocene horizon is folded into a series of anticlines in the Southern Zone and along the eastern edge of the basin, indicating compression and consequent shortening. The North and South Taranaki Grabens are mainly normal-fault controlled features, indicating extension of those regions. The smooth, widely-spaced contours of the western half of the map indicate no significant deformation of the horizon there since the Eocene. These same factors are also demonstrated by the cross sections (Enclosure 2.1).

A numerical estimate of the amount of compression and extension required to deform this horizon to its present shape can be obtained by bed-length balancing a series of seismic reflection transects across the deformed regions. This is done by selecting seismic reflection profiles which are oriented approximately orthogonal to the observed deformation, and which have been interpreted for the top-Eocene reflector, and measuring the length of that horizon. The difference between the measured length of the top-Eocene reflector and the length of the profile is the amount of shortening or extension accommodated along the profile.

Section balancing has been done for several seismic reflection traverses in Taranaki, using sections interpreted for the preparation of the regional maps discussed in Appendix 1. The results are shown in Figure 2.4. Nine traverses, 
some involving multiple seismic profiles oriented end-to-end, have been computed. These traverses do not extend significantly onto the Western Platform, where there has been little Neogene deformation, or across the Taranaki Fault, where seismic profiles may not be recording the total amount of deformation.

Four of the balanced profiles are across the extensional regions of the North and South Taranaki Grabens. These show that the Neogene extension required to form the grabens increases from south to north in the study area. No extension is apparent south of the southernmost end of the large Maui structure (part of which is the Maui Gas Field). Just east of the Maui Field, about one kilometre of extension is measured. North of the Taranaki Peninsula about 2 kilometres is measured, and by the northern edge of the map, west of Kawhia Harbour, about 3 kilometres of extension is measured.

Slightly more compression is required to form the anticlinal structures of the southern zone. Five profiles were balanced in this region, one of which is about 30 degrees from orthogonal and indicates about 7 kilometres of shortening, compared with a nearby orthogonal measurement of $4 \mathrm{~km}$. About $3 \mathrm{~km}$ of shortening is required in the vicinity of the Kupe South Field. All of these values, for both shortening and extension, are small compared to the length of the traverses measured, which ranged from 15 to $170 \mathrm{~km}$ long, and very small compared with the $300 \mathrm{~km}$ width of the study area.

The extension of the grabens is predominantly a Pliocene and younger phenomenon. In comparison the Southern Zone compression is predominantly late Miocene. In the vicinity of the Maui Field, the present extension is reversing compressional motion previously associated with the Cape Egmont Fault Zone in this region (Thrasher 1990a). The North and South Taranaki Grabens appear to be a rotational opening of a graben system propagating southwards and progressively replacing the Southern Zone compression with extension. 


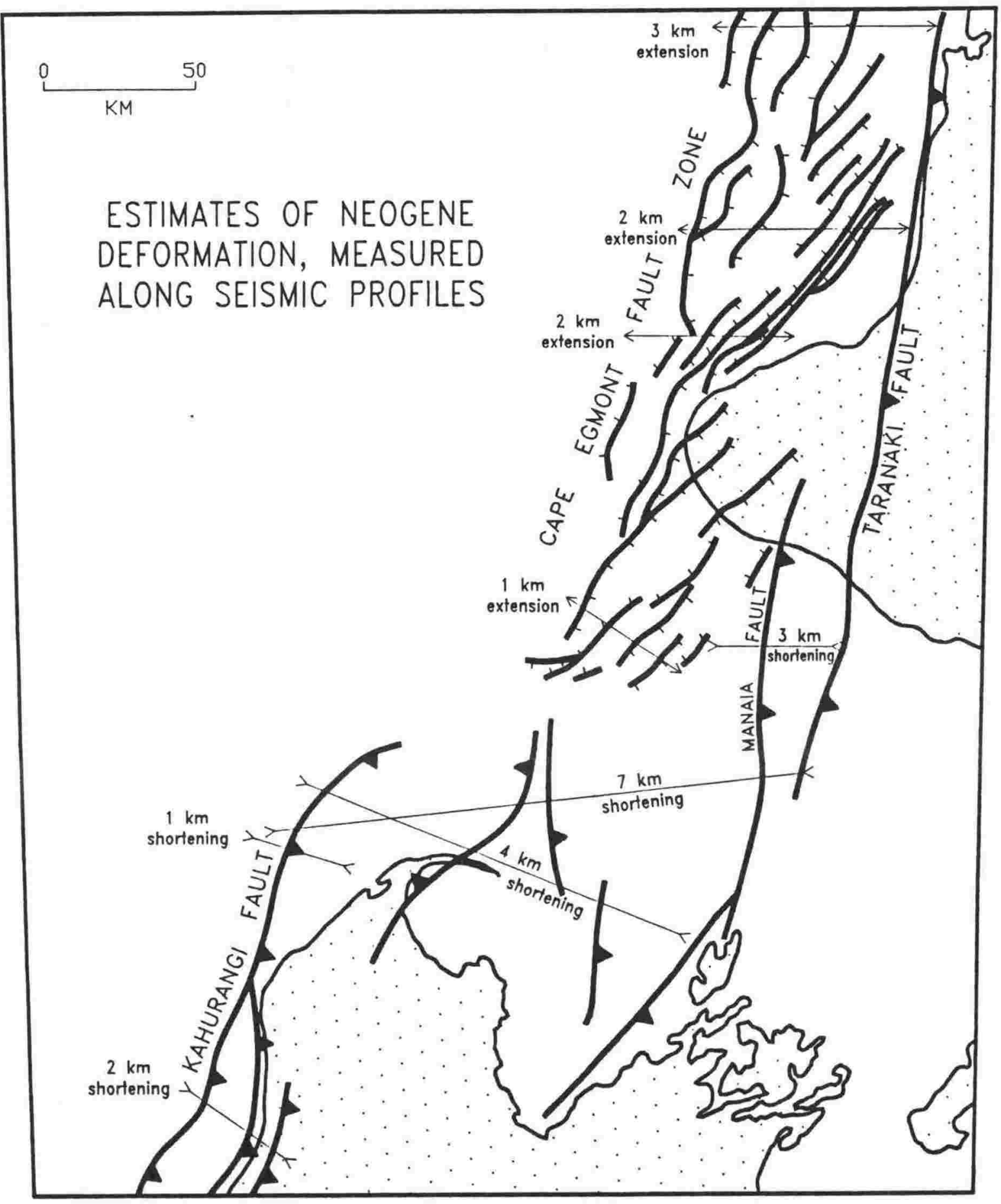

Figure 2.4 Neogene deformation measured along seismic reflection profiles. 
Pilaar and Wakefield (1978) suggested a right-lateral, first-order wrench fault system, located between a north-south shear couple, to explain the present distribution of faults within the basin. Knox (1982) continued this model, although pointing out that it was "applicable in a simple case where undeformed sediments overlying a basement fault undergo deformation for the first time." Most of the Tertiary faulting in the basin, such as the Cape Egmont Fault Zone, is reactivating Cretaceous normal faults. These faults are probably aligned in response to the early-rift stress regime. A wide range of possible late-Tertiary stress orientations could have led to their reactivation. Many faults in the basin appear to have multiple phases of late-Tertiary reactivation, often involving changes in throw. The right-lateral model of Pilaar and Wakefield (1978) does not appear to explain this changing stress field during the late Tertiary, or explain the orientation and reverse throw of the Taranaki Fault Zone.

On the top-Eocene structure map (Enclosure A.1), the Cape Egmont Fault Zone appears as a series of en echelon, discontinuous fractures. If this en echelon fault system formed in response to strike-slip motion of basement rocks underlying the sedimentary sequence, which seems probable, then the experimental work of Naylor and others (1986) may be applicable. That study documents the progressive formation of faults in sandbox models of sedimentary sequences overlying basement wrench offsets. Their results show that for lateral basement offsets of more than about half the sediment overburden thickness, a continuous, through-going fault system develops in the sedimentary sequence. En echelon faulting, as a series of Riedel shears and first-order splays, occurs when wrench-fault offset is less than about one-half the sediment thickness.

Sediment thickness over the Cape Egmont Fault Zone is generally less than six kilometres. Assuming vertical offsets in basement and lateral changes in sediment thickness do not significantly affect the formation of late-Tertiary faults, then the en echelon configuration of the Cape Egmont Fault Zone is well explained as a set of Riedel shears and first order splays formed in response to right-lateral basement wrench motion of no more than a few kilometres. This 
is of the same magnitude as the late-Tertiary vertical motions along this fault system.

Most of the motion on the Cape Egmont Fault Zone is Pliocene and younger (Thrasher 1991). Miocene volcanic edifices in the subsurface of northern Taranaki straddle the fault zone and are vertically offset by the normal motion of the faults. They do not have significant lateral offset (Thrasher 1991). Because any late-Tertiary shear has been minor (less than a few $\mathrm{km}$ ), the fault zone should be considered a mainly-extensional feature.

The only major fault systems within the basin that do not appear to be reactivated, or controlled by, older faults are the Turi Fault Zone, north of the Taranaki Peninsula, and the reverse faulting within and immediately north of Tasman Bay. The Turi Fault Zone does not appear to significantly affect the thickness of the Cretaceous sediments across the faults, and therefore must have little strike-slip motion on it. Onshore, to the east of the Turi Fault Zone, faults with a similar trend and age (and presumably continuous with the Turi Fault Zone) do not appear to have significant strike-slip offset (Smith and others 1987).

In Tasman Bay, within the Southern Zone of compression, Thrasher (1989) has shown the faulting to be Miocene dip-slip, which is unlikely to have accommodated significant strike-slip motion, although differences in trend and timing on different fault sets indicate a changing stress field through the Miocene. The conclusion that the motion on the major reverse faults of this region has been dominantly dip-slip is based on the observation that the isopach of Paleocene-Eocene sediment is uniform across the faults and that although sinuous, the faults maintain remarkably uniform dip and throw for their entire lengths of up to $100 \mathrm{~km}$.

Most of the anticlinal structures of the Southern Zone are formed by compressional reactivation of rift-related normal faults. Figure 2.5 is a seismic 


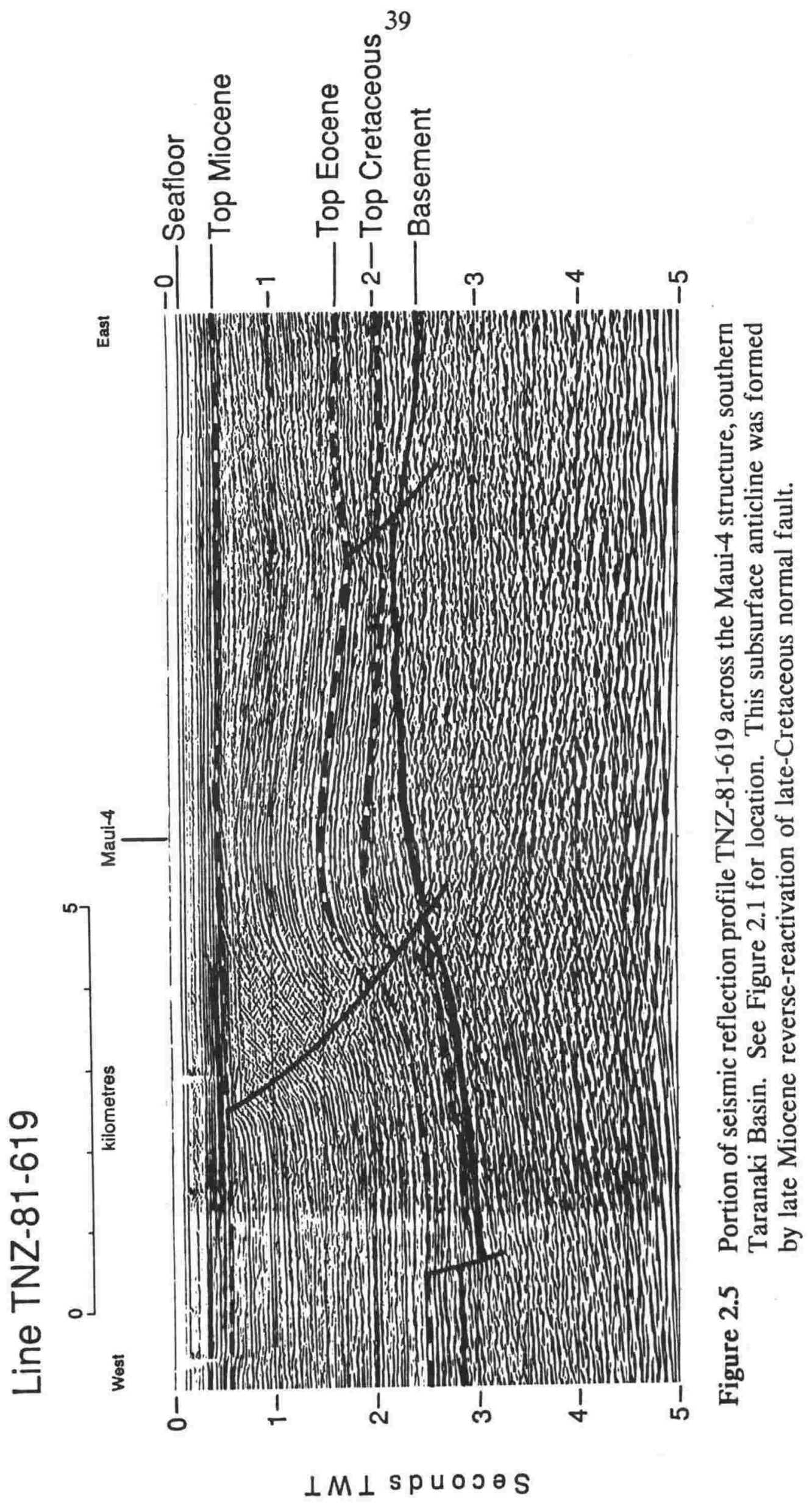


reflection profile across the Maui-4 structure showing the typical form of these structures. Harding (1985) refers to this type of structure as "positive structural inversion", and considers them to be the result of dip-slip compression, without significant wrench motion.

\subsection{Pre-Neogene disposition of the eastern margin of the basin}

As previously mentioned, the Taranaki Fault Zone forms the eastern margin of Taranaki Basin. The amount and style of deformation associated with this fault zone is one of the major problems facing any attempt to understand the early history of the basin, as it abruptly terminates the syn-rift and passive-margin sequences deposited in Taranaki Basin prior to the Oligocene.

There is considerable evidence that Oligocene sediments were once widespread east of the Taranaki Fault Zone. Oligocene outliers rest on basement at Picton and Otaihanga (north of Wellington) (Grant-Taylor 1978). These outliers are well indurated and must have been deeply buried prior to late-Neogene uplift and exposure. In the north, on the eastern flanks of the Herangi High, Oligocene sediments of the Te Kuiti Group onlap basement over a considerable area (Schofield 1978, Kear and Schofield 1959). The oldest sediment encountered in any petroleum exploration well on the Eastern Taranaki High is also Oligocene, resting on basement, in exploration well Puniwhakau-1 (St. John 1965) inland from Mt. Egmont. Oligocene sediments must thus have been widespread over the present Eastern Taranaki High prior to the Neogene tectonic episode which resulted in the uplift and erosion of the high.

This evidence for Oligocene sedimentation contrasts starkly with the lack of evidence for Cretaceous-through-Eocene sediments over the Eastern Taranaki High, which are thick and widespread immediately to the west of the Taranaki Fault Zone. Within the Eocene sequence penetrated by the petroleum exploration well Awakino-1, just west of the fault zone, significant recycled 
Mesozoic pollen (mostly Jurassic) have been observed (Hoskins and Morgans 1985; and D. Mildenhall, pers. com.). These recycled pollen indicate the nearby exposure of Kawhia Syncline-related basement rocks; the same rocks that are today adjacent to this portion of the basin (Hay 1967). The margin of the basin must have been fairly steep to have exposed basement in proximity to this portion of the basin, which contains over 4 kilometres of pre-Neogene sediments.

The only possible pre-Oligocene sediments related to the Eastern Taranaki High and immediately adjacent to Taranaki Basin are a few small, fault-bounded outcrops of Eocene coal measures near Nelson city (Johnston 1981). The relationship of these outcrops to Taranaki Basin is unclear, but they are small remnants which have been caught-up within the faults. Their original location and relationship with the basement blocks which bound them has not been ascertained. It seems unlikely that significant Taranaki Basin syn-rift and passive-margin sediments ever occupied the region immediately east of the Taranaki Fault Zone.

The amount by which the Eastern Taranaki High has overridden the original eastern extent of the basin cannot be definitively determined. Seismic reflection profiles do indicate that the Taranaki Fault is reverse and that Taranaki Basin sedimentary sequences extend east of the leading edge of the basement overthrust. The pre-fault sedimentary sequence, including the syn-rift sediments, can be imaged under the leading edge of the basement overthrust eastward until they are truncated by the thrust. East of this, basement is juxtaposed against basement, and there is no evidence of any sedimentary section. Figures 2.6 and 2.7 are portions of seismic profiles which cross the fault zone. Figure 2.6 is in the extreme north of the study area, while Figure 2.7 is in the south. The steepness of the reverse faults and the generally small amount of forethrust deformation in the sedimentary sequence make it seem unlikely that the basement block has moved a substantial distance westward over the basin. The reverse fault heave of basement over the late Cretaceous 


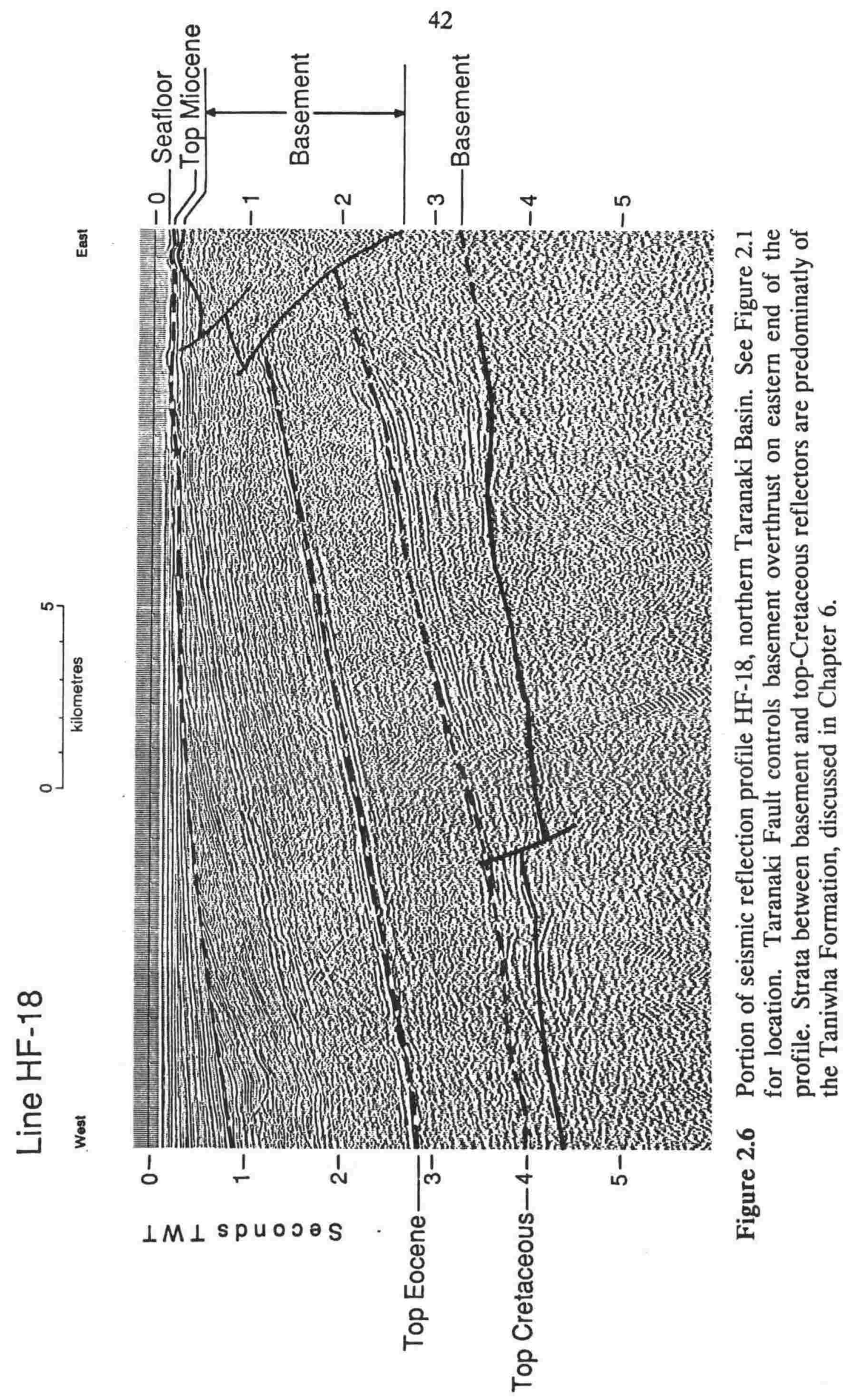




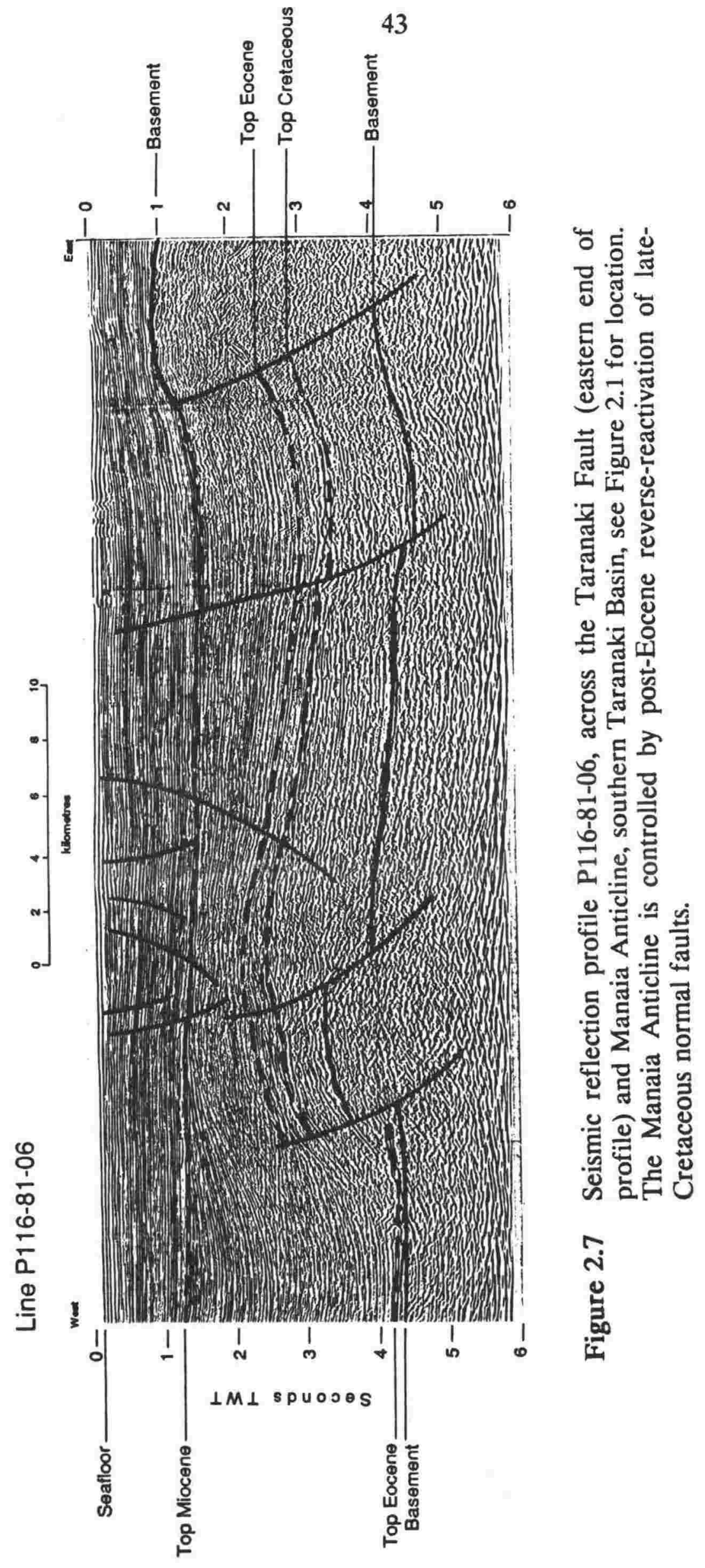


sedimentary sequence is less than $5 \mathrm{~km}$ on figures 2.6 and 2.7 , and reaches a maximum of about $10 \mathrm{~km}$ under the northern portion of the Taranaki Peninsula. Considerably more shortening could have been accommodated on sub-parallel faults within the basement block. Stern (1990) suggested, based on comparison of a deep seismic reflection line from southern Taranaki Basin with similar data from the Pyrenees, that the Taranaki Fault Zone may have accommodated up to $100 \mathrm{~km}$ of shortening, but this cannot be verified using the sedimentary record of Taranaki Basin.

On Figure 2.6 the Cretaceous section is shown to thicken eastward, into the Taranaki Fault. This suggests that a west-dipping normal fault may have controlled the the original eastern edge of the basin. This possible fault control of the basin margin has been alluded to by Thrasher (1990b), King (1990), Mills (1990) and King and Thrasher (in press), but the details continue to be elusive. Oversteepening of this margin, through a series of imbricate thrust faults in basement, is sugested by King (1990), Mills (1990) and King and Thrasher (in press) as a possible mechanism for the transition from west-dipping normal fault to east-dipping reverse fault. However, this mechanism is difficult to reconcile with the lack of deformation of the sedimentary sequence being truncated by the fault, as oversteepening would have put the basin fill under compression.

The model suggested by Thrasher (1990b) calls for the Taranaki Basin to have been originally bounded on the east by the upper plate of a large east-dipping detachment fault in basement. During Tertiary compression, this detachement reactivated as a reverse fault and the upper plate was pushed back over the sedimentary fill of the basin.

In reviewing the Taranaki/Manaia Fault systems, McDougall and Thrasher (1991) presented evidence that the Taranaki Fault has probably not undergone major strike slip movement during its Oligocene through Miocene phase of movement. They concluded that lateral motion on the fault system is probably 
less than $5 \mathrm{~km}$. Stern (1990) also considered Taranaki Fault Zone motion as largely dip-slip, based on the interpretation of a deep-seismic-reflection profile.

However, large amounts of Neogene wrench motion could have been accommodated on sub-parallel faults within the basement block which forms the Eastern Taranaki High. McQuillan (1977) considered North Wanganui Basin sedimentation, on the upthrown side of the fault zone, to have been controlled by wrench faulting, and King (1990) presented plate tectonic evidence which called for substantial transpression on this boundary of the Taranaki Basin.

Overall, it appears that the Taranaki Fault has probably not uplifted, laterally offset, or overthrust a significant portion of the late Cretaceous sedimentary sequence of Taranaki Basin. The original eastern edge of the basin may have been only a few kilometres east of the present fault truncation of the syn-rift sequence. The evidence that this eastern side of the basin was not covered by sediment until the Oligocene indicates that the original basin boundary along this side must have been quite steep, allowing for the transition from several kilometres of pre-Oligocene sediment west of the basin margin to Oligocene sediments resting on basement east of the basin margin.

The composition of basement underlying Taranaki Basin sedimentary sequences is poorly known. The only information comes from sparse onshore outcrops around the periphery of the basin and from the few exploration wells that have reached basement. In general, the subsurface distribution of basement rock types proposed by Wodzicki (1974) has been confirmed by more recent drilling (Mortimer and others 1991). The Taranaki Fault appears to be the crustal contact between basement rocks with an upper-crustal, Paleozoic to Mesozoic, meta-sedimentary affinity on the eastern side and lower-crustal, Gondwana continental rocks to the west. Hence, basement under Taranaki Basin generally is expected to be igneous and high-grade metamorphic rocks. 
This basement contact across the Taranaki Fault indicates that the fault is one of the fundamental boundaries in the geologic framework of New Zealand. The origin of this contact is unknown, but clearly polyphase. It may represent a suture zone formed during obduction of material onto the Gondwana continental margin, which has been reactivated. In 1972, Waterhouse and Norris published a model for the Rangitata Orogeny which would require that this contact be such a suture ("Fyfe's Line" in their Figure 4).

Another possibility is that the Taranaki Fault is a pre-rift, middle-Cretaceous wrench fault. The thickening of the lowest sedimentary sequences toward the fault may be entirely within the pre-rift "Taniwha Formation" (discussed in chapters 6 and 7). It is possible that the deposition of these rocks was controlled by a strike-slip, or even compressional, fault system active during the middle of the Cretaceous (Clarence to Raukumara epochs), and located immediately east of the present Taranaki Fault. Such a fault system may have included the Manganui Fault, a major, probably Cretaceous and possibly strikeslip fault within basement rocks in the Awakino area (Campbell and Raine 1989).

\subsection{Conclusions}

There is no convincing evidence for any substantial (more than a few km) post-Cretaceous strike-slip motion on any faults within the basin. The present distribution of pre-Tertiary sediments within the basin can be taken to approximate, within a few kilometres, their position of deposition relative to the basin. Therefore, the isopach map of Cretaceous sediments can be assumed to represent the original distribution of Cretaceous deposits in the basin. There are a few exceptions, the most important of which is along the eastern margin, where the Taranaki Fault has replaced a steep basin margin which was probably very near the present location of the fault. 
Another exception is the southern end of the Manaia Anticline, which extends south from the Kupe South region, and is controlled by the Manaia Fault. This anticline was a Cretaceous rift-related graben, which was everted during the Miocene, and deeply eroded. The Tahi- 1 well was drilled into the eroded remains of the original Cretaceous section, and encountered marine strata overlying non-marine strata (Palmer 1984). The original extent of late Cretaceous sedimentation southward along the graben axis cannot be estimated.

One last exception is the breached anticline, exposing a core of Cretaceous sediments, which occupies the Pakawau region of Northwest Nelson, on the South Island (Bishop 1971). This anticline is formed by reverse motion on the Wakamarama Fault, which has everted a large Cretaceous basin of Taranakirelated rift origin. It is the most southerly extent of syn-rift sedimentation in the study area, and the only subbasin which is exposed in outcrop. The geology of this outcropping sequence is documented in Chapter 4.

\subsection{References}

Anderton, P.W. 1981: Structure and evolution of the South Wanganui Basin, New Zealand. New Zealand Journal of Geology and Geophysics 24(1): 39-63.

Bishop, D.G. 1971: Sheet S1, S3 and part S4, Farewell-Collingwood (1st Edition) "Geological map of New Zealand" 1:63 360. Department of Scientific and Industrial Research, Wellington, New Zealand.

Campbell, H.J.; Raine, J.I. 1989: Biostratigraphic evidence for the Manganui Fault, near Awakino, southwest Auckland. Journal of the Royal Society of New Zealand 19(1): 43-53. 
Grant-Taylor, T.L. 1978: Southwest Wellington and Northeast Marlborough. In Suggate, R.P.; Stevens, G.R.; Te Punga M.T., eds., The Geology of New Zealand, Vol. 2: 470-471.

Harding, T.P. 1985: Seismic characteristics and identification of negative flower structures, positive flower structures, and positive structural inversion. The American Association of Petroleum Geologists Bulletin, Vol. 69: 582-600.

Hay, R.F. 1967: Geological map of New Zealand 1:250 000, sheet 7 (1st ed.), Taranaki. Department of Scientific and Industrial Research, Wellington, New Zealand.

Hoskins, R.H.; Morgans, H.E.G. 1985: Reconnaissance biostratigraphy of Awakino-1 offshore oil well. New Zealand Geological Survey report PAL 98.

Johnston, M.R. 1981: Sheet O27AC Dun Mountain (1st. ed.). Geological map of New Zealand 1:50 000. Map (1 sheet) and notes (40 p.). New Zealand Department of Scientific and Industrial Research, Wellington, New Zealand.

Kear, D.; Schofield, J.C. 1959: Te Kuiti Group. New Zealand Journal of Geology and Geophysics 2(4): 685-717.

King, P.R. 1990: Polyphase evolution of the Taranaki Basin, New Zealand: changes in sedimentary and structural style. In: Ministry of Commerce (1990), 1989 New Zealand Oil Exploration Conference Proceedings: 134-150.

King, P.R.; Robinson, P.H. 1988: An overview of Taranaki region geology, New Zealand. Energy Exploration and Exploitation 6(3): 213-232.

King, P.R.; Thrasher, G.P. (in press): Post-Eocene development of the Taranaki Basin, New Zealand: convergent overprint of a passive margin. American Association of Petroleum Geologists, memoir 53, chapter 11. 
Knox, G.J. 1982: Taranaki Basin, structural style and tectonic setting. New Zealand Journal of Geology and Geophysics 25(2): 125-140.

McDougall, J.; Thrasher G.P. 1991: Cenozoic Tectonics of the southeastern Taranaki Basin. Abstract in: Geological Society of New Zealand miscellaneous publications 59A: 88 .

McQuillan, H. 1977: Hydrocarbon potential of the North Wanganui Basin, New Zealand. The APEA Journal, Vol. 87: 4109-4125.

Mills, C. 1990: Gravity expression of the Patea-Tongaporutu High and subsequent model for the Taranaki Basin margin. In: Ministry of Commerce (1990), 1989 New Zealand Oil Exploration Conference Proceedings: 191-200.

Mortimer, N.; Beggs, J.M.; Davy, B.; Tulloch, A.J.; Thrasher, G. 1991: Geometry of basement terranes beneath the Taranaki and Wanganui Basins. Abstract in: Geological Society of New Zealand miscellaneous publications 59A: 97.

Naylor, M.A.; Mandl, G.; Sijpesteijn C.H.K. 1986: Fault geometries in basement-induced wrench faulting under different initial stress states. Journal of Structural Geology 8(7): 737-752.

Palmer, J. 1984: Tahi-1 well completion report. Unpublished open-file petroleum report 1030, filed at DSIR Geology and Geophysics, Lower Hutt.

Pilaar, W.F.H.; Wakefield, L.L. 1978: Structural and stratigraphic evolution of the Taranaki Basin, offshore North Island, New Zealand. The APEA Journal, Vol. 10: 93-101. 
St. John, D.H. 1965: Puniwhakau-1 (n120/02 (R20/01)) exploration well resume. Unpublished open-file petroleum report 455, filed at DSIR Geology and Geophysics, Lower Hutt.

Schofield, J.C. 1978: Auckland, South Auckland, and Coromandel Range. In Suggate, R.P.; Stevens, G.R.; Te Punga M.T., eds., The Geology of New Zealand, Vol. 2: 449-456.

Smith, G.O.; Fleming, T.L.; Van Nieuwenhuise, R.E. 1987: Geological and Geophysical evaluation of PPL 38087 North Taranaki Basin, New Zealand. Unpublished open-file petroleum report 1243, filed at DSIR Geology and Geophysics, Lower Hutt.

Stern, T. 1990: The application of deep seismic reflection profiling to petroleum exploration: an example from the South Taranaki Basin. In: Ministry of Commerce (1990), 1989 New Zealand Oil Exploration Conference Proceedings: 42-54.

Thrasher, G.P. 1989: Miocene faulting in Tasman Bay, New Zealand. Research notes, 1989, New Zealand Geological Survey Record 40.

Thrasher, G.P. 1990a: The Maui Field and the exploration potential of southern Taranaki; a few unanswered questions. Petroleum Exploration in New Zealand News, July 1990: 26-30.

Thrasher, G.P. 1990b: Tectonics of the Taranaki Rift. In: Ministry of Commerce (1990), 1989 New Zealand Oil Exploration Conference Proceedings: 124-133.

Thrasher, G.P. 1991: Evolution of the Cape Egmont Fault Zone, Taranaki Basin, New Zealand. Geological Society of Australia, Abstracts 30: 174-175. 
Waterhouse, J.B., \& Norris, G., 1972: Paleobotanical solution to a granite conundrum: Hawks Crag Breccia of New Zealand and the tectonic evolution of the Southwest Pacific. Geoscience and man, 4: 1-15.

Wodzicki, A. 1974: Geology of the pre-Cenozoic basement of the Taranaki-Cook Strait-Westland area, New Zealand, based on recent drillhole data. New Zealand Journal of Geology and Geophysics 17(4): 747-757. 


\section{CHAPTER 3: TECTONICS OF THE TARANAKI RIFT}

\subsection{Chapter abstract}

Recent seismic mapping of the Taranaki region has revealed the structure of the earliest sedimentary sequences within Taranaki Basin. The basin first formed as the "Taranaki Rift", a zone of late Cretaceous (Haumurian) extension synchronous with oceanic spreading within the Tasman Sea. The rift was an obliquely extensional zone which probably transferred the opening of the New Caledonia Basin southward into the Tasman Basin. Along the rift, a series of small basins oriented northeast-southwest were formed. Most of these basins were controlled by high angle normal faulting on one side only (generally the western side). The rotation on these controlling faults indicates that they probably become sub-horizontal detachment faults within basement.

Since initial rifting, the basin has undergone a complex history of further subsidence, compression and additional rifting, usually involving reactivation of the Cretaceous rift-controlling faults. Hence the tectonics of the earliest rift phase still influences the architecture of the basin.

\subsection{Introduction}

Taranaki Basin is a predominantly north-south, subsurface feature. The present basin is bounded to the east by the Taranaki Fault, a major reverse fault which vertically offsets basement by more than five kilometres. To the west the basement gradually shallows onto the Challenger Plateau, an oceanic bathymetric high. The northern and southern limits of the basin are not well defined. To the north and northwest the basin merges with the bathyal New Caledonia Basin, while to the south it merges with the numerous small basins of the northwestern South Island. 
The objective of this chapter is to develop a tectonic model for the late Cretaceous history of Taranaki Basin, based upon seismic reflection mapping, and upon the limited well and outcrop information available from Cretaceous sequences within the basin.

Only 12 petroleum exploration wells have penetrated Cretaceous strata in Taranaki Basin (Figure 3.1). Completion reports for these wells are now open-file, and their references are listed in Table 3.1. Most have penetrated only Haumurian (Maastrichtian: latest Cretaceous) section, but rocks of Clarence (Albian to Cenomanian: middle Cretaceous) age occur in Te Ranga-1 (Shell BP and Todd 1986). These Clarence-age rocks are considered in the present study to constitute a pre-rift sequence, and no strata older than Haumurian age are identified as having a rift association. The stratigraphy and interpretation of the Cretaceous sedimentary rocks will be discussed in detail in Chapter 6.

\subsection{Late Cretaceous physiography}

Figure 3.2 is an isopach map of Cretaceous sediments in Taranaki Basin, simplified from Enclosure A.2. As discussed in Chapter 2, Cretaceous strata are preserved in two depositional settings: firstly, as a thin (generally less than 1000 m) unit underlying much of the western portion of the basin (the Western Platform of Pilaar and Wakefield 1978), and, secondly, as much thicker (up to $4000 \mathrm{~m}$ ) deposits in isolated, fault-controlled, basins.

Many of these basins lie in a zone about $50 \mathrm{~km}$ wide and $400 \mathrm{~km}$ long aligned NE-SW between Albatross Point on the North Island and the northwest corner of the South Island. Another group of small basins is concentrated in the northern part of map area, where Taranaki Basin merges with the New Caledonia Basin. These northern subbasins are mostly controlled by major 


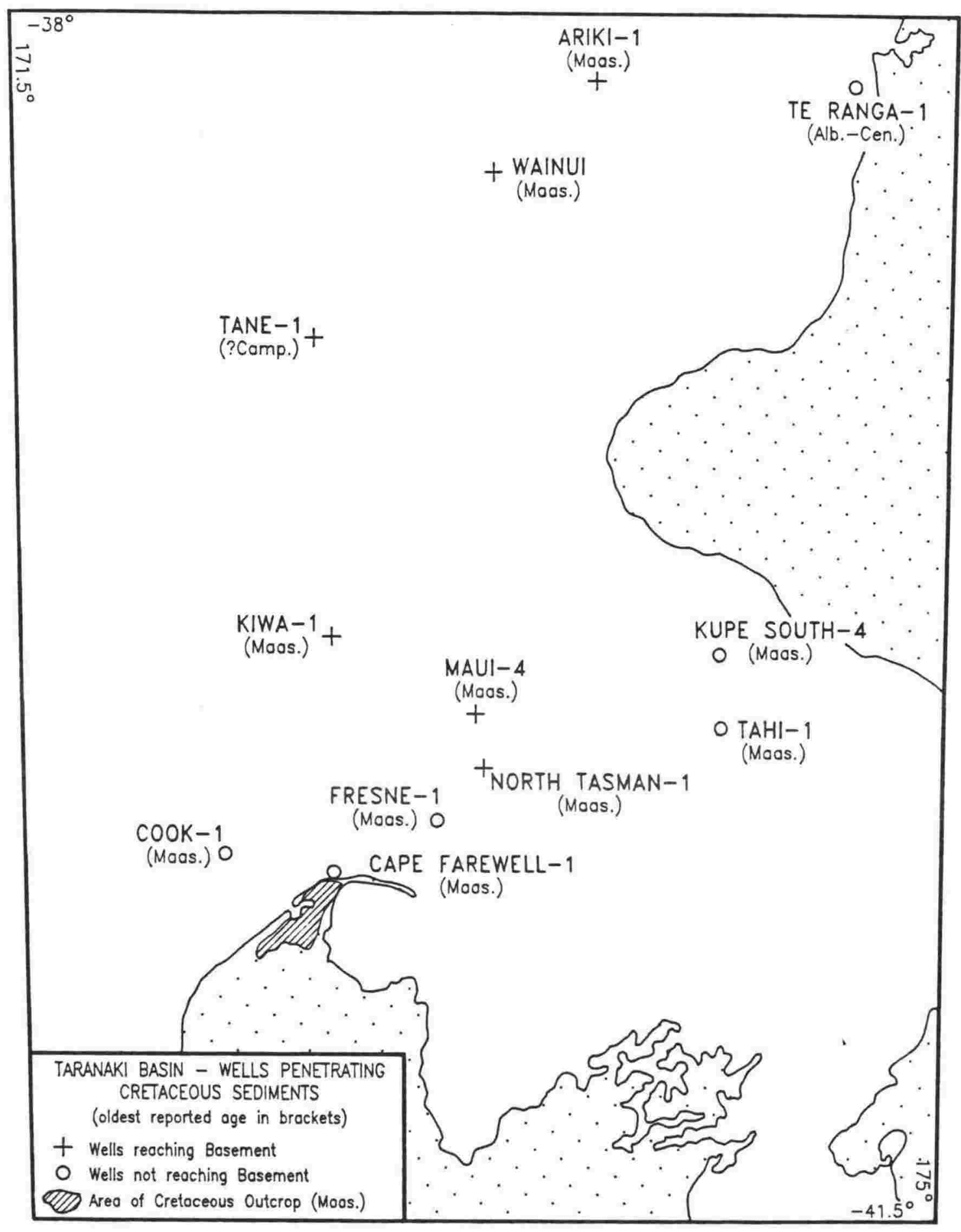

Figure 3.1 Location of wells penetrating Cretaceous sedimentary sequences of the Taranaki Rift. 
TABLE 3.1 Open-file wells intersecting Cretaceous sediments

Well Name

Ariki-1

Cape Farewell-1

Cook-1

Fresne-1

Kiwa-1

Kupe South-4

Maui-4

North Tasman-1

Tahi-1

Tane-1

Te Ranga-1

Wainui-1
Company

Date PR\#

Shell BP \& Todd Oil Services $\quad 1984 \quad 1038$

Petrocorp Exploration

$1987 \quad 1234$

N.Z. Aquitaine Petroleum

$1970 \quad 513$

N.Z. Aquitaine Petroleum

$1976 \quad 674$

Shell BP \& Todd Oil Services

$1982 \quad 880$

TCPL Resources

$1989 \quad 1483$

Shell BP \& Todd Oil Services

$1970 \quad 543$

Aquitaine(Australia and NZ) $\quad 1979 \quad 736$

Petrocorp Exploration

19841030

Shell BP \& Todd Oil Services

$1977 \quad 698$

Shell BP \& Todd Oil Services

19861197

Shell BP \& Todd Oil Services $\quad 1982 \quad 869$

Note: "PR\#" refers to Petroleum Report number of well-completion report lodged on open-file with DSIR Geology and Geophysics, Lower Hutt. 
CRETACEOUS ISOPACH (M)

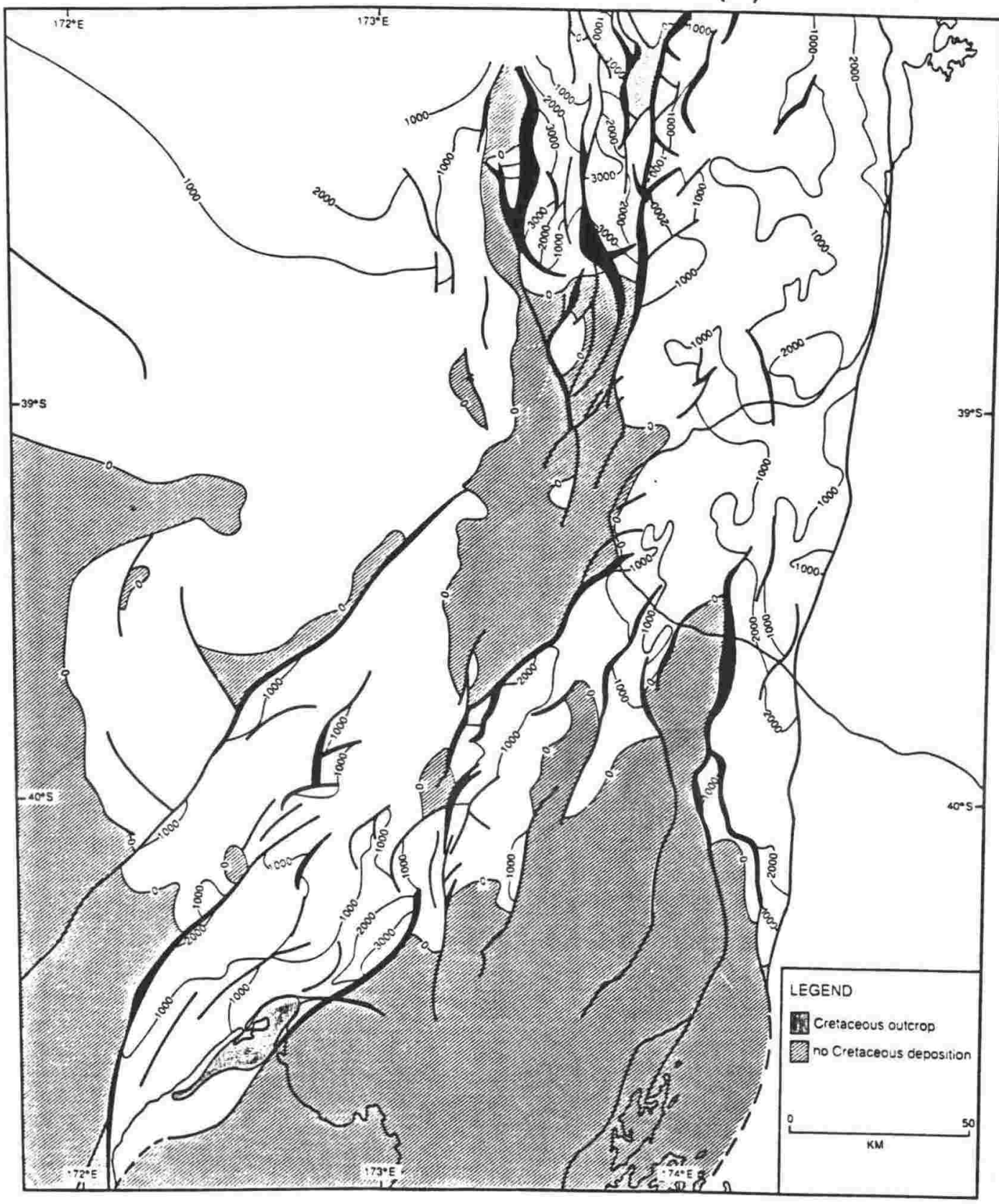

Figure 3.2 Generalized isopach map of late Cretaceous sediments, Taranaki Basin. Contour interval $1000 \mathrm{~m}$. 
north-south, down-to-the-east, normal faults. Another Cretaceous basin is the north-south graben lying between the Manaia and Taranaki faults in the southeast of the Taranaki Basin. Together, these basins form a subsurface physiographic link connecting the eastern end of the New Caledonia Basin to the mountainous terrain of the western South Island.

The en echelon grouping of a series of small, fault-controlled basins to form a major physiographic lineation in continental crust is generally recognised as an indication of continental rifting. Rosendahl (1987) reviewed the extensive and, as he phrased it, "confusing and misleading," literature on continental rift architecture, and proposed a uniform system for rift nomenclature. Within this system, which views rifts as continental-scale features, the Taranaki Basin lateCretaceous subbasins would constitute a "rift zone"; a morphologically obvious rift trend with a length of 500 to $700 \mathrm{~km}$, and end boundaries which usually coincide with major offsets, kinks or changes in a larger system. Rosendahl (1987) applied this terminology to East Africa, and concluded that the Malawi, Rukwa, Tanganyika, Albert, Gregory and Turkana rifts are all "rift zones" and part of the larger continental-scale East African Rift System.

The late Cretaceous subbasins of the Taranaki region, as shown on Figure 3.2, constitute the Taranaki Rift, a rift zone which has its northern termination at the eastern end of the New Caledonia Basin. The southern termination of the Taranaki Rift has been subsequently obscured by the Tertiary compressional tectonic features of the South Island. The larger scale rift system of which the Taranaki Rift is part includes the New Caledonia Basin to the north, and probably the Tasman Sea spreading system south and west of the South Island, and will be examined in more detail later.

There is no evidence of rift-related volcanism associated with the Taranaki Rift. There are no anomalies on seismic reflection data that can be ascribed to riftrelated volcanics and late Cretaceous sedimentary sequences are not known to incorporate volcanic detritus or clastics that cannot be attributed to erosion from 
volcanogenic basement rocks. Although many continental rifts do contain volcanic rocks within the rift-fill sequence (referred to as "wet" by Rosendahl 1987), some continental rifts are "dry" and have little or no associated volcanic activity (Rosendahl 1987).

\subsection{Lateral offset across the Taranaki Rift}

The Taranaki Rift is a portion of a continental-scale reorganization of crustal blocks. The lateral motion between crustal blocks across the rift can be derived from the geometry of the faults which were formed during rift activity. On the isopach map of the Cretaceous interval (Figure 3.2, simplified from Enclosure A2) the faults which control Cretaceous sedimentation have two predominant orientations: many are oriented roughly north-south, while another major set is oriented northeast-southwest (Figure 3.3).

Withjack and Jamison (1986) have published an account of research which used clay models and analytical results to investigate the deformation produced by oblique rifting. Their results indicated that the rose-diagram pattern depicted on Figure 3.3 should be produced by an oblique rift that combines extension with left-lateral shear. If this interpretation is applied to the Taranaki Rift, then the northeast-southwest faults should parallel the rift trend and have sinistral offset. The north-south faults should be oriented about $30^{\circ}$ from the rift trend and be predominantly normal faults. The isopach map does indicate that the north-south faults do have greater normal offset than those oriented northeastsouthwest.

The clay-model results of Withjack and Jamieson (1986) have been more recently tested using sand-silicone models by Tron and Brun (1991). The results of Tron and Brun essentially confirm those of Withjack and Jamieson, except for slightly more uncertainty in the determination of rift separation from fault 


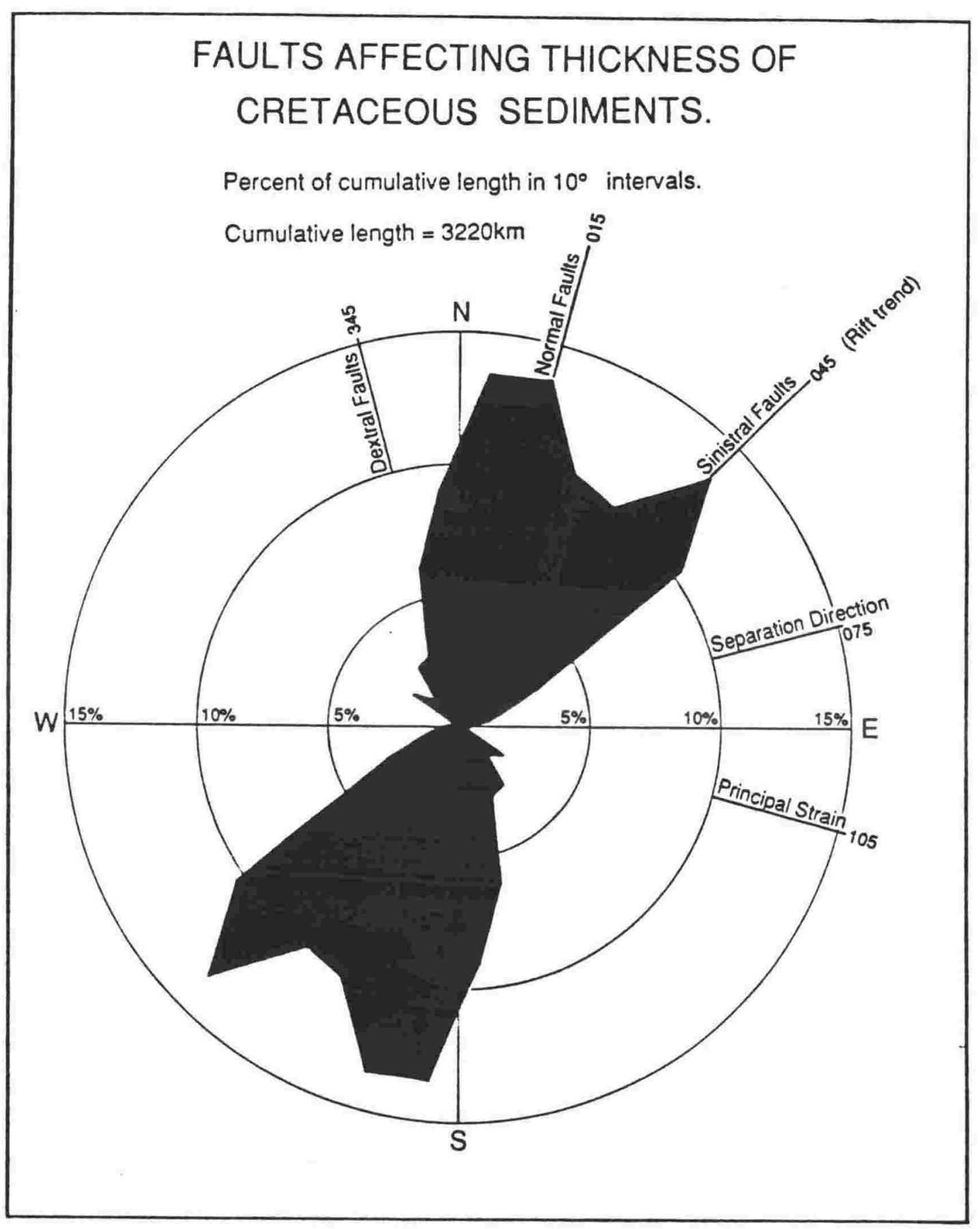

Figure 3.3 Rose diagram of faults affecting the thickness of Cretaceous sediments in Taranaki Basin. See text for explanation. 
trends, and the observation of mixed-mode motion (dip-slip and strike-slip) on most rift-related faults. Mixed-mode motion is inferred for many Taranaki Rift faults, judging from the normal throw on most of the probable strike-slip (northeast-southwest) faults.

Predictions of the Withjack and Jamison rifting model are indicated in Figure 3.3. These predictions include the suggestions that a set of subordinate dextral faults should be present, oriented at about $345^{\circ}$, that the principal strain in the rift system should be oriented at about $105^{\circ}$ and that the separation direction across the rift should be about $075^{\circ}$.

There is evidence for only a few faults in the Taranaki Rift with a northwest-southeast trend. Wodzicki (1974) showed that the basement grain under Taranaki is expected to be north-south to northeast-southwest. These cross-cutting, and minor, faults may be hard to propagate across such a basement grain.

The principal strain direction of about $105^{\circ}$ is approximately that which would be expected from the isopach map. This east-west stretching of the region explains the general north-south trend of the basin.

The total offset along and across the Taranaki Rift is difficult to estimate. The rift-related normal faults are quite steep, and hence do not require large heaves to produce the observed dip-slip offsets. Summation of fault heaves depicted on the Cretaceous isopach map (Enclosure A.2) across the rift, along the principal strain direction, gives a total separation of about $10 \mathrm{~km}$. The principal strain direction is $60^{\circ}$ from the strike-slip fault trend, hence $10 \mathrm{~km}$ of across-rift strain requires about $20 \mathrm{~km}$ of along-rift strike-slip motion. 


\subsection{Detachment faulting in the Taranaki Rift}

The observation of late Cretaceous strike-slip motion within Taranaki Basin, and its comparison to a continental transform zone, bring up the possibility that the Taranaki Rift is not a rift at all, but a series of strike-slip basins along a master wrench fault. The subsurface character of wrench faults has been considered by Harding $(1985,1990)$, who established that the main criteria for identifying wrench faults systems is that they are controlled by a master fault which steepens with depth (Harding 1990). Figure 2.3 is a portion of a seismic reflection line perpendicular to one of the major north-south normal faults in the northern portion of the basin. Note that the Cretaceous sedimentary sequence fans into the fault-angle graben, indicating that the downthrown basement block has rotated along the normal fault. Etheridge and others (1988) show that such a rotation should sole out into a detachment fault at depth. Using the area cross-section balancing technique of Gibbs (1983), the detachment depth for this fault is at about $12 \mathrm{~km}$ below the Cretaceous surface, or about $18 \mathrm{~km}$ below present sea level.

The Maui-4 structure (Figure 4.2) is a compressive reactivation of a Cretaceous rotational fault-angle graben, indicating that under favourable compressional stress, extensional faults in Taranaki Basin can reactivate. Mainly-Miocene compressional reactivation of rift-related faults has formed many of the anticlinal structures of southern Taranaki Basin. In contrast, in the North Taranaki Graben late-Miocene through Recent extension has reactivated many of the rift-related faults as normal faults. Thrasher (1990a) observed that the South Taranaki Graben adjacent to the Maui Field is a post-Miocene extensional feature that is forming due to the extensional reactivation of a major late Miocene reverse fault, that is itself a compressional reactivation of a late Cretaceous rift-related fault. 

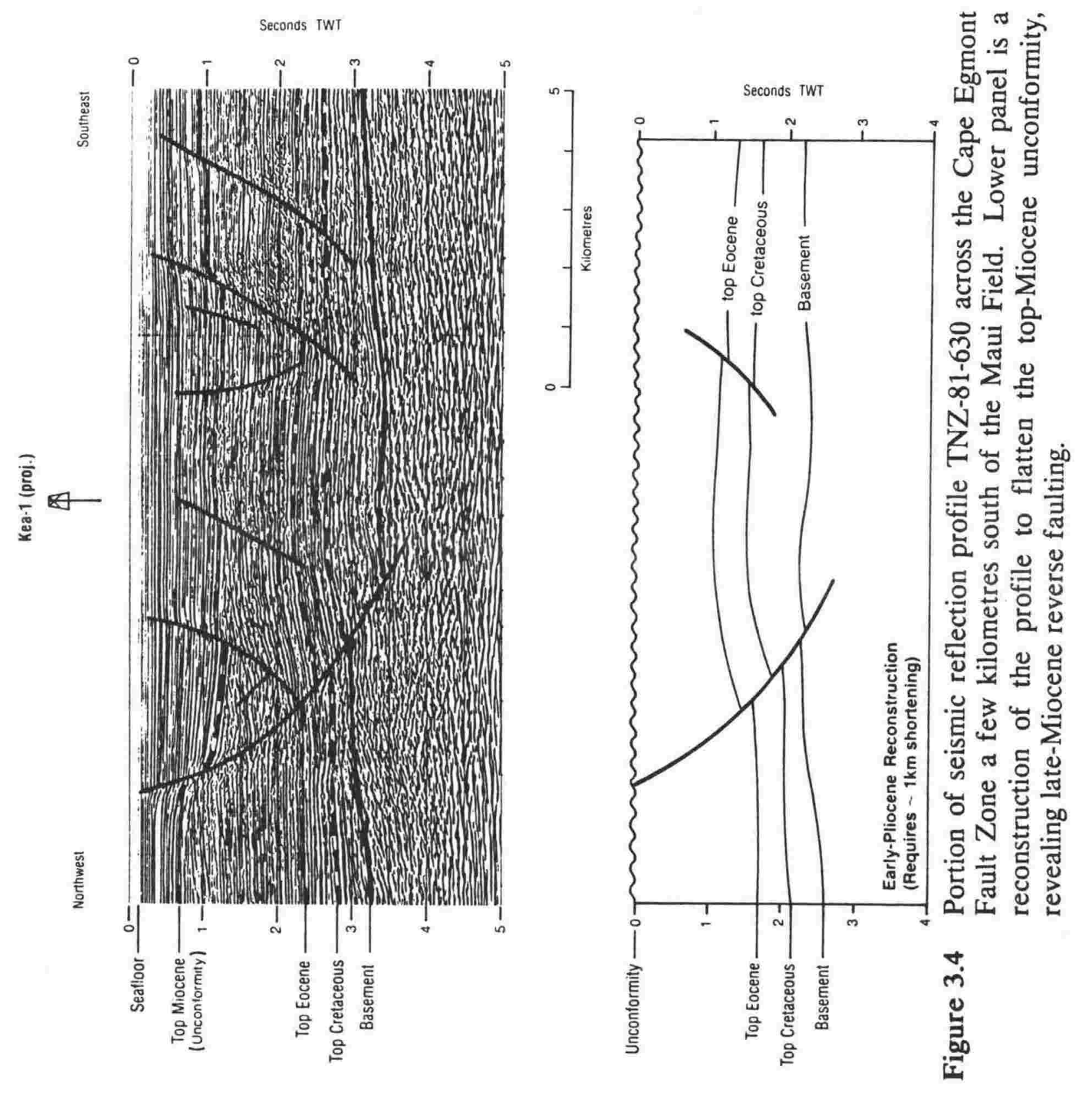
This repeated reactivation of late Cretaceous rift faulting is illustrated in Figure 3.4, a seismic reflection profile reproduced from Thrasher (1990a). Depth conversion of the seismic reflection profile allows this line to be reconstructed to previous geometries through bed-length balancing, a method discussed in Chapter 2. Doing so for this line reveals that the post-Miocene extension requires approximately $800 \mathrm{~m}$ of lateral motion along the profile (which is oriented at right angles to the anticipated extensional direction). The late Miocene shortening of the structure requires $400 \mathrm{~m}$ of lateral motion, and the late Cretaceous extensional requires $900 \mathrm{~m}$ of lateral motion.

The major basement fault which controls all three phases of structural activity on the Figure 3.4 cross section has a curvature which indicates it becomes horizontal in basement, as a detachment fault. Cross-sectional-area balancing (using the method of Gibbs 1983) applied to this profile indicates that for all three phases of fault motion the depth to detachment is approximately 8 to 9 $\mathrm{km}$ below the present-day surface. Therefore, it appears likely that all three tectonic phases are reactivating the same detachment surface. Vertical throw on the fault, both normal and reverse, is probably a consequence of horizontal motion on the detachment due to lateral extension or compression in the basement rocks. Reactivation of the original extensional grain of the basin indicates that the architecture of Taranaki Basin throughout the Tertiary has been controlled by the architecture inherited from the Taranaki Rift.

These observations that the extensional faults probably sole out into detachment surfaces within the upper crust is not consistent with a wrench fault interpretation for the Taranaki Rift. There is no indication of any throughgoing master wrench fault, or any faults that steepen with depth. The Taranaki Rift does appear to be an extensional rift, with detachment at upper crustal levels, but one that has accommodated sinistral motion. 


\subsection{Relationship of the Taranaki Rift to the New Caledonia Basin and the} Tasman Sea

The separation direction predicted by the fault-trend analysis discussed in Section 3.4 suggests that the present Challenger Plateau and western North Island were, during the Cretaceous, moving away from each other obliquely across the Taranaki Rift. One way to explain this motion is to assume that the New Caledonia Basin was opening at the same time and that the Taranaki Rift was a mechanism for transforming the New Caledonia rift motion southwards without propagating a rift through the present North Island. This can be verified by showing the New Caledonia Basin to be time-coincident with the Taranaki Rift, and that motion associated with that opening can be accomodated by the rift.

Using data from Deep Sea Drilling Project leg 21, Burns and Andrews (1972) suggested that the New Caledonia Basin was in existence by the end of the Cretaceous, and is therefore probably a Cretaceous feature. Uruski and Wood (1991) have recently presented an interpretation of geophysical data from the New Caledonia Basin, in which they conclude that the basin was most likely formed during the late Cretaceous, and that rift-related faulting ceased during the Paleocene. Therefore, the crustal thinning associated with the New Caledonia Basin was probably time-coincident with sea floor spreading in the Tasman Sea (82 to $60 \mathrm{Ma}$, according to Weissel and Hayes 1977). Uruski and Wood (1991) also concluded that New Caledonia Basin crustal thinning did not proceed as far as the formation of oceanic crust (hence only a few tens of kilometres of stretching) and that the principal rifting direction is roughly parallel to the rifting direction presented by Thrasher (1990b) for Taranaki Basin (which is the same as that presented in the present study). Uruski and Wood also point out that this is very similar to the rifting direction presented by Tulloch and Kimbrough (1989) for the West Coast of the South Island during the middle Cretaceous. 
The evidence of Uruski and Wood (1991) for the New Caledonia Basin, and that presented here for the Taranaki Basin, suggest that the two basins were active at the same time (Haumurian), and were time-coincident with oceanic spreading in the Tasman Sea. The New Caledonia Basin/Taranaki Rift system is not a failed rift which preceded breakup of Gondwana, but was an internal adjustment within the New Zealand/Lord Howe Rise continental block during Tasman Sea spreading. The Taranaki Basin may be a continental transform zone, with a fairly small offset, which joined the Tasman Sea with continental rifting in the New Caledonia Basin. Along the southwards projection of the Taranaki Rift, down the west coast of the South Island, lie the late Cretaceous through Paleocene basins of the Paparoa Trough and the South Westland Embayment (Nathan and others 1986). These basins contain late Cretaceous coal measures and sandstones very similar to the strata deposited in the basins along the Taranaki Rift (Nathan and others 1986), and may be the southern continuation of the rift to the Tasman Basin. The trend of the Taranaki Rift is approximately the same as that of fracture zones in the Tasman Sea (as portrayed in Weissel and Hayes 1977).

The observation that the New Caledonia Basin and the Taranaki Rift are timecoincident with Tasman Sea spreading is very significant. Most of the literature on continental rifting assumes that rifts are a precursor to oceanic spreading, and that rifts which do not proceed to the emplacement of oceanic crust have "failed". Thus an inactive continental rift is thought to be either a continental margin adjacent to oceanic crust, or, if surrounded by continental crust, a failed rift. The published models available for crustal structure, and fault style, in continental rifts consider seafloor spreading to be the natural end point of continental rifting (for example Rosendahl 1987; Falvey 1974; Tamsett 1984; Dunbar and Sawyer 1989; Morley 1989; Lister and others 1986, 1991; and many more).

Lister and others (1991) and Etheridge and others (1989) both use the Lord Howe Rise/New Caledonia Basin pair as an example of possible low-angle long- 
distance detachment during continental breakup, under the assumption (unsupported in both studies) that they are features which preceded Tasman Sea spreading. Wood (1991) described a newly-discovered basin, the Challenger Basin, on the southern edge of the Challenger Plateau and gave its most likely age as early or middle Cretaceous, on the assumption that the basin was a Tasman Sea precursor. However, the data presented by Wood (1991) would be explained just as well if the basin were a late Cretaceous feature whose development was coeval with Tasman Sea oceanic crustal emplacement.

Some Tasman Sea marginal basins, such as the Gippsland Basin of southeast Australia, were probably initated during the continental rifting that preceded the initiation of the Tasman Sea spreading. The New Caledonia Basin and the Challenger Basin may be such marginal basins. However, the premiss that failed continental rifting is a precursor of nearby seafloor spreading needs much better testing, especially considering that present models of rift and continental margin development are often applied to rifts and basins, such as the Taranaki Rift, which are coeval with seafloor spreading.

\subsection{References}

Burns, R.E., \& Andrews, J.E., 1972: Regional aspects of deep sea drilling in the Southwest Pacific. In: Davies, T.A. (ed), Initial reports of the deep sea drilling project, volume XXI, U.S. National Science Foundation, 897-905.

Dunbar, J.A.; Sawyer, D.S. 1989: How preexisting weaknesses control the style of continental breakup. Journal of geophysical research 94(B6): 7278-7292.

Etheridge, M.A., Symonds, P.A., \& Powell, T.G., 1988: Application of the detachment model for continental extension to hydrocarbon exploration in extensional basins. Australian petroleum exploration association journal, 28 : 167-187. 
Etheridge, M.A., Symonds, P.A., \& Lister, G.S., 1989: Application of the detachment model to reconstruction of conjugate passive margins. In Tankard, A.J.; Balkwell, H.R., eds., Extensional tectonics and stratigraphy of the North Atlantic Margins. American association of petroleum geologists memiors, 46: 23-40.

Falvey, D.A. 1974: The development of continental margins in plate tectonic threory. Australian petroleum exploration association journal, 14: 95-106.

Gibbs, A.D., 1983: Balanced cross-section constructions from seismic sections in areas of extensional tectonics. Journal of structural geology, 5: 152-160.

Harding, T.P. 1985: Seismic characteristics and identification of negative flower structures, positive flower structures, and positive structural inversion. The American association of petroleum geologists bulletin, 68(4):582-600.

Harding, T.P. 1990: Identification of wrench faults using subsurface structural data: criteria and pitfalls. The American association of petroleum geologists bulletin, 74(10):1590-1609.

Lister, G.S.; Etheridge, M.A.; Symonds, P.A. 1986: Detachment faulting and the evolution of passive continental margins. Geology, 5: 246-250.

Lister, G.S.; Etheridge, M.A.; Symonds, P.A. 1991: Detachment faulting and the evolution of passive continental margins. Tectonics 5(10):1038-1064.

Morley, C.K. 1989: Extension, detachments, and sedimentation in continental rifts (with particular reference to East Africa). Tectonics 8(6): 1175-1192.

Nathan, S.; Anderson, H.J.; Cook, R.A.; Herzer, R.H.; Hoskins, R.H.; Raine, J.I.; Smale, D. 1986: Cretaceous and Cenozoic sedimentary basins of the West 
Coast region, South Island, New Zealand. New Zealand Geological Survey basin studies 1 .

Pilaar, W.F.H., \& Wakefield, L.L., 1978: Structural and stratigraphic evolution of the Taranaki Basin, offshore North Island, New Zealand. The APEA journal, 10: $93-101$.

Rosendahl, B.R. 1987: Architecture of continental rifts with special reference to East Africa. Annual reviews of Earth and planetary science, vol 15: 445-503.

Shell BP and Todd 1986: Well resume - Te Ranga-1 PPL 38107 Taranaki. Unpublished open-file petroleum report 1197, filed at DSIR Geology and Geophysics, Lower Hutt.

Tamsett, D. 1984: Comments on the development of rifts and transform faults during continental breakup; examples from the Gulf of Aden and northern Red Sea. Tectonophysics 104: 35-46.

Thrasher, G.P. 1990a: The Maui Field and the exploration potential of southern Taranaki; a few unanswered questions. Petroleum exploration in New Zealand news (July, 1990):27-30.

Thrasher, G.P., 1990b: Tectonic control of early-rift (Cretaceous) sedimentation, Taranaki Basin, New Zealand. Geological Society of Australia abstracts 24: 151-152.

Tron, V., Brun, J.P. 1991: Experiments on oblique rifting in brittle-ductile systems. Tectonophysics 188: 71-84.

Tulloch, A.J., Kimbrough D.L. 1989: The Paparoa metamorphic core complex, Westland-Nelson, New Zealand: Cretaceous extension associated with fragmentation of the Pacific margin of Gondwana. Tectonics, 8: 1217-1234. 
Uruski, C., Wood, R. 1991: Structure and stratigraphy of the New Caledonia Basin. Exploration Geophysics 22: 411-418.

Weissel, J.K., \& Hayes, D.E., 1977: Evolution of the Tasman Sea reappraised. Earth and planetary science letters 36: 77-84.

Withjack, M.O., \& Jamison, W.R., 1986: Deformation produced by oblique rifting. Tectonophysics, 126: 99-124.

Wodzicki, A., 1974: Geology of the pre-Cenozoic basement of the Taranaki-Cook Strait-Westland area, New Zealand, based on recent drillhole data. New Zealand journal of geology and geophysics, 17(4): 747-757.

Wood, R.A. 1991: Structure and seismic stratigraphy of the western Challenger Plateau. New Zealand journal of geology and geophysics, 34(1): 1-9. 
CHAPTER 4: GEOLOGY AND PETROLEUM POTENTIAL OF THE PAKAWAU BASIN, NORTHWEST NELSON

\subsection{Chapter abstract}

Taranaki Basin syn-rift sediments of the Pakawau Group outcrop only in the Pakawau region of Northwest Nelson. Up to $4000 \mathrm{~m}$ of these terrestrial and shallow-marine sediments were deposited in the north-plunging Pakawau Basin. Formation of the basin was controlled by down-to-the-west normal motion on the Wakamarama Fault and by down-to-the-east motion on the mirror-image Kahurangi Fault. The late Cretaceous sediments are included in the Pakawau Group, which comprises two formations: the Rakopi Formation (new name), and the North Cape Formation. The lowest, conglomeratic unit of the Rakopi Formation is the Otimataura Conglomerate Member. The North Cape Formation in the Pakawau Basin includes the Fresne Conglomerate Member and the coal-bearing Puponga Member. Early Tertiary strata are included in the Farewell Formation of the Kapuni Group.

During the late Tertiary the basin underwent contraction, which reactivated the Wakamarama and Kahurangi faults as reverse faults, and resulted in the folding and uplift of the syn-rift strata. This uplift has exposed the basin fill to subaerial erosion, allowing for inspection of the sequence as a model for the rift-related sediments deeply buried in other late Cretaceous basins beneath Taranaki. Outcrop information can be combined with subsurface data from the three petroleum exploration wells in the basin to ascertain the petroleum potential of the basin.

\subsection{Introduction}

In the Pakawau region of Northwest Nelson a major sequence of late Cretaceous through Paleogene sedimentary rocks is exposed in outcrop. The 
outcrop area is located on the $30 \mathrm{~km}$ long and $20 \mathrm{~km}$ wide structurallycontrolled peninsula terminating at Cape Farewell, the northernmost point of the South Island (Figure 4.1). Cretaceous through Paleogene rocks outcrop over most of the peninsula, and continue in the subsurface several tens of kilometres to the north and west. These strata were deposited in the fault-controlled Pakawau Basin, and uplifted and exposed in the Neogene.

Structural control of the peninsula is provided by anticlinal folding of the strata (the Wakamarama Anticline). The anticline is asymmetric, with the western limb dipping northwest at 10 to $20^{\circ}$ (Bishop 1971), and is truncated along the steeper eastern limb by the Wakamarama Fault. The Tasman Sea is actively eroding the folded and uplifted Tertiary beds along the western and northern sides of the peninsula. The anticline is breached and deeply eroded. This erosion, coupled with rising sea levels, has allowed the sea to invade the peninsula and form Whanganui Inlet, a large, shallow system of drowned stream valleys. Away from Whanganui Inlet, the sedimentary sequence is eroded into steep hills and gorges.

The region is isolated, bush-covered, and sparsely populated. Coastal outcrop exposure along the western and northern sides of the peninsula is very good, as is exposure around the shores of Whanganui Inlet. Inland from the coast, however, exposure is poor and access is difficult.

During the late nineteenth and early twentieth centuries coal and gold were actively mined in this region. Bituminous and subbituminous coal were extracted from the sedimentary sequence exposed in the anticline (Ongley and Macpherson 1923). Gold was extracted from both basement rocks and overlying cemented conglomerates of the coal measures (Park 1890a). Small scale coal mining continued in the region until 1974, when the Puponga mine closed down, but probably less than one million tonnes of coal were recovered from the district in total (Wells 1984a). 


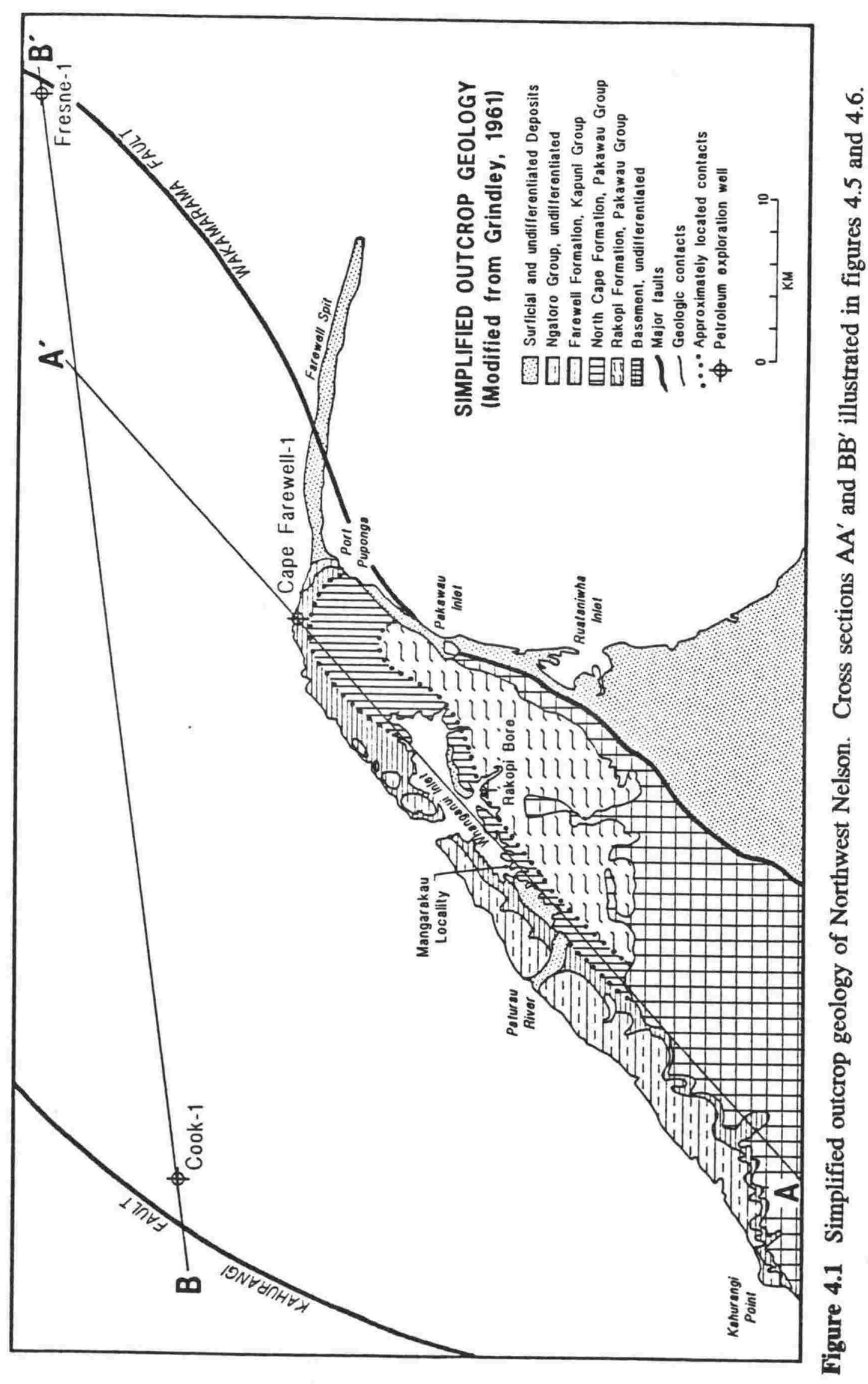


The thickness of exposed sand- and organic-rich sediments, combined with the large-scale anticlinal folding, have attracted petroleum explorers for several decades. Most explorers have concluded that the onshore sequence, although containing potential source rocks, did not present any petroleum prospects, as deep erosion had exposed the potential reservoir rocks (for example, see Harrison and Van Oyen 1969).

Exploration continued in the offshore, where the sequence has not been subjected to as much erosion. Two exploration wells have been drilled into the Wakamarama Anticline: Fresne-1 (N.Z. Aquitaine Petroleum 1976) and Cape Farewell-1 (Carter and Kintaner 1987). Cape Farewell-1 was drilled from an onshore location, but was deviated to an offshore bottom-hole location. Both wells yielded weak hydrocarbon shows, but neither discovered producible hydrocarbons. The Cape Farewell-1 well was abandoned before reaching the intended exploration target, due to engineering problems and slow drilling, and probably did not intersect any strata within structural closure.

To determine the reasons for the failure of these two wells, and to better assess the petroleum potential of the Pakawau Basin, (and, indeed, of Taranaki Basin) the geology of the Pakawau region needs to be carefully reconsidered. The Pakawau Basin is the southernmost of the late Cretaceous rift basins that initiated the development of Taranaki Basin. It is also the only place where syn-rift sediments deposited during the first ten-to-twenty million years of Taranaki Basin's history are exposed for examination.

\subsection{Previous geologic investigations}

The geologic investigation of northwest Nelson began in the early years of New Zealand's European colonization, and coal was first discovered in the Pakawau region in 1842 (Ongley and Macpherson 1923). In the following years, geologic investigations by Forbes, Hochstetter, Haast, Hector, Hutton and Cox helped 
delineate the geology and mineral resources of the area (Ongley and Macpherson 1923).

James Park conducted the first systematic geological mapping of the Pakawau region during 1888 (Park 1890a) and 1889 (Park 1890b). He recognized the folded strata of the anticline to be of "Cretaceo-Tertiary" age and erected a stratigraphy broadly similar to that accepted today (Figure 4.2). In 1907, Bell and others described the basal contact of these sedimentary rocks onto the underlying basement rocks in the vicinity of the Golden Ridge gold mines, in the far south of the outcrop area.

The geology of the Pakawau region is described in New Zealand Geological Survey Bulletin 25 (Ongley and Macpherson 1923). Of particular note is the stratigraphic division of the sedimentary rocks into "Pakawau Series" and overlying "West Haven Series". Ongley and Macpherson reported the structure of the area to be a series of tilted fault blocks, one of which is controlled by the Wakamarama Fault, which tilts Pakawau strata westward.

H.W. Wellman, in an unpublished 1950 manuscript, adopted the stratigraphic definition of Ongley and Macpherson for the Pakawau Series, which he also refered to as the "Lower Coal Measures" and considered to be late Cretaceous in age. Overlying the Pakawau Series, Wellman placed the "Middle Coal Measures" of lower Tertiary age, although he stated the contact is poorly defined and accepted the location of the contact presented by Ongley and Macpherson (1923) "without significant alteration." The thickness of the Middle Coal Measures was given as 700 to 800 feet $(200$ to $250 \mathrm{~m})$. The contact between these two units was considered by Wellman to be a major disconformity, with considerable erosion of Pakawau Series beds prior to the near-conformable deposition of the Middle Coal Measures. The marine beds of the "Landon Series" may conformably overlie the Middle Coal Measures, but Wellman indicated the evidence was conflicting. 


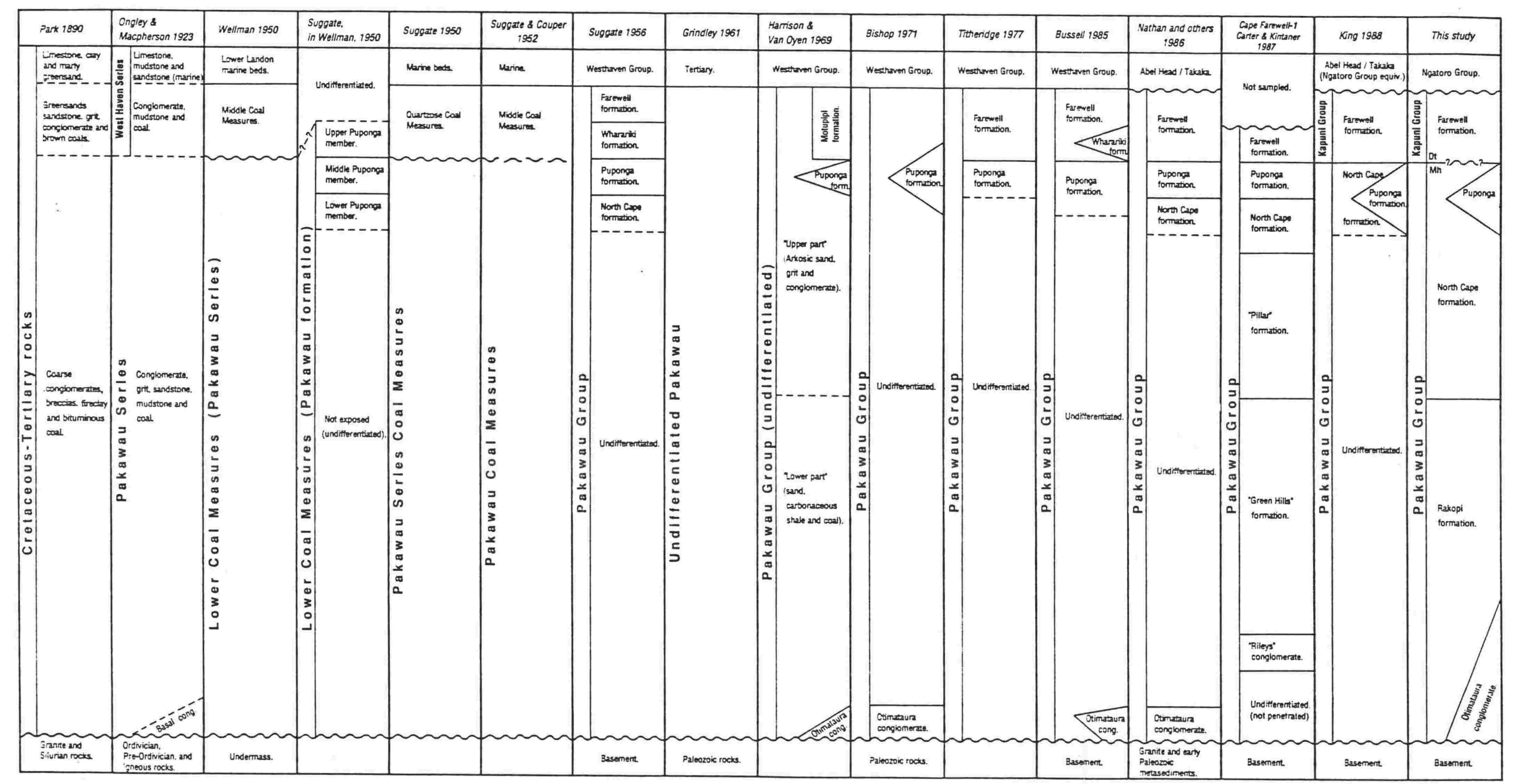

Figure 4.2 Comparative stratigraphic nomenclatures applied to the outcropping late Cretaceous through Paleogene sequence of Northwest Nelson. 
Wellman did recognize folding of the Pakawau strata, and his 1950 manuscript describes for the first time the asymmetric Wakamarama Anticline, running along the eastern side of the peninsula.

Included in the Wellman (1950) manuscript is another unpublished manuscript by R.P. Suggate on the coal resources of the Pakawau region. This presented a history of mining, and proposed a preliminary stratigraphy for the Puponga district. Suggate's stratigraphy used the terminology "Lower Coal Measures (Pakawau Formation)" for the coal-bearing rocks at Puponga, and stated that "no clear distinction is evident between the Lower and Middle coal measures". The upper part of the Lower Coal Measures was subdivided into Upper, Middle and Lower Puponga members, which paralleled the later (Suggate 1956) Wharariki, Puponga and North Cape formations. Also included is the detailed log of a drillhole sunk near Rakopi, on Whanganui Inlet, in 1915 and sometimes refered to as "Bassett's Bore" (for example in Bishop 1971). Figure 4.3 is a lithologic column for this bore (here refered to as the Rakopi Borehole), based on the log presented by Suggate, which he ascribes to data held "at Mines Department, Wellington."

In 1956 Suggate published a detailed account of the Puponga Coalfield, including the logs for several drillholes in the vicinity of the coalfield. Suggate (1956) is the source of much of the stratigraphic terminology presently applied to the Pakawau sedimentary sequence. In his stratigraphic scheme, Suggate broke with previous workers by extending the "Pakawau Group" upwards to include the Middle Coal Measures, and confined the "Westhaven Formation" to the overlying Whaingaroan through Otaian (Oligocene through early Miocene) marine beds. Suggate (1956) subdivided the upper part of the his new Pakawau Group, in the Puponga area, into four formations: the Farewell Formation plus the Wharariki, Puponga and North Cape formations mentioned above (see Figure 4.2). The uppermost of these, the $600 \mathrm{ft}(200 \mathrm{~m})$ thick Farewell 


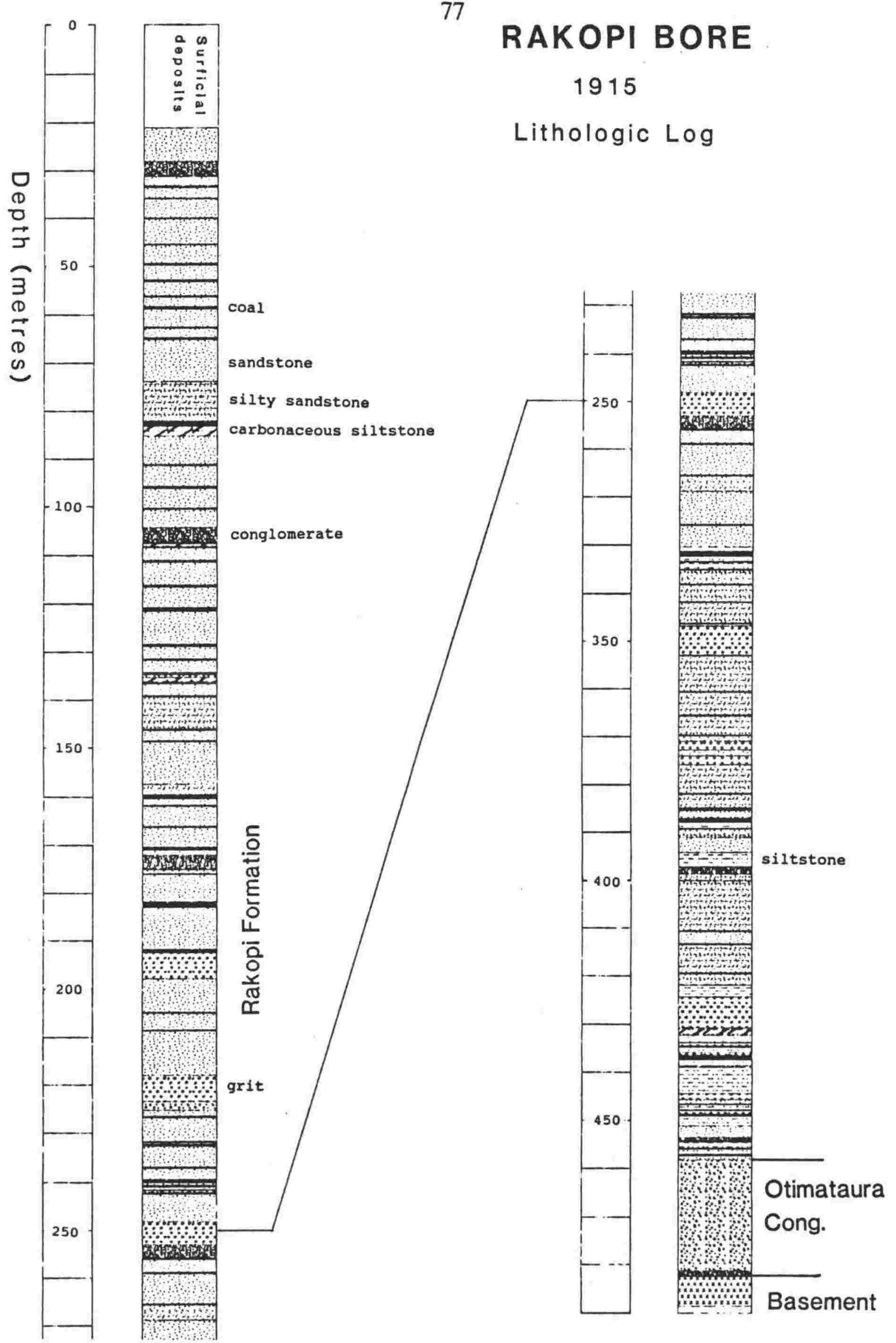

Figure 4.3 Lithologic log of the Rakopi Borehole. See Figure 4.1 for location. 
Formation, which was considered to be early Tertiary, corresponded approximately with the "Middle Coal Measures".

Suggate (1959) published a major study of the physical properties of New Zealand coals and their geologic setting. He observed that the coal rank (an indicator of burial depth) in the Pakawau Group increases eastward across the outcrop area, but that this increase is slight. Suggate also suggested that coal measure sedimentation along the West Coast, including the Pakawau strata, was controlled by a series of "miniature geosynclines" which then tectonically reversed, or "everted" (a concept attributed to $\mathrm{H}$. Wellman) to form the present anticlines.

Grindley (1961) published the 1:250,000 Golden Bay geologic map, which included the Pakawau region. Grindley adapted the Pakawau Group terminology of Suggate (1956). but the stratigraphic column showed the entire group to be late Cretaceous (although the text is less certain, and leaves open the possibility of sedimentation into the early Tertiary). The text indicates that the structure of the region could be attributed to a period of Miocene "tectonic eversion" with "the lower Tertiary depressions forming the upper Tertiary 'highs' and the lower Tertiary 'highs' forming the upper Tertiary depressions."

Bishop $(1968,1971)$ also followed Suggate's Pakawau Group nomenclature when he mapped the area at a scale of 1:63,360. The Pakawau Group outcrop area is covered by two map sheets, the Kahurangi (Bishop 1968) and Farewell-Collingwood (Bishop 1971) sheets. Bishop's stratigraphic columns show the Pakawau Group as being non-marine, mostly Mata (late Cretaceous) series rocks, but continuing upwards into the early Tertiary. On the Farewell-Collingwood sheet (Bishop 1971) the Pakawau Group is subdivided into three formations; the basal Otimataura Conglomerate is overlain by up to $4000 \mathrm{ft}(1200 \mathrm{~m})$ of undifferentiated Pakawau Group strata, which are interrupted in the Puponga area by the laterally discontinuous, coal bearing, Puponga Formation, up to $800 \mathrm{ft}(250 \mathrm{~m})$ thick. Bishop's maps show the area 
to be cut by numerous faults, many of them inferred from aerial photographs. The depicted geology, however, indicates that these faults have minimal offset.

Using the preliminary results of Bishop (published in 1968 and 1971), Harrison and Van Oyen (1969) conducted field work in the Pakawau region to investigate the petroleum potential of the region. The previously undifferentiated Pakawau Group was split by Harrison and Van Oyen into two informal units: the "lower part" and the "upper part". The "lower part" outcrops in the eastern portion of the outcrop area, and is distinguished by being poorly-sorted carbonaceous sands and muds with numerous thin coal' seams. The "upper part" outcrops in the west and consists of poorly sorted, coarse, white sands and grits. This upper unit appears to correlate with Suggate's (1956) Farewell, Wharariki and North Cape formations. Harrison and Van Oyen concluded that although potential source rocks were present within the onshore portion of the Pakawau Basin, no petroleum prospects exist as deep erosion has exposed the potential reservoir rocks.

The most complete study of the sedimentology of the Pakawau Group was by Titheridge (1977). This MSc study was limited to the upper few hundred metres of the group, and concentrated on the northern end of the peninsula. Titheridge suggested amalgamating Suggate's (1956) Farewell and Wharariki formations into an expanded Farewell Formation at the top of the Pakawau Group. Otherwise he left Suggate's (1956) stratigraphy unchanged, and did not include the Otimataura Conglomerate of Bishop (1971).

In his sedimentological study, Titheridge concluded that the Pakawau Group was entirely non-marine and had accumulated in a rapidly subsiding trough. $\mathrm{He}$ also concluded that braided stream sedimentation was responsible for the North Cape and Farewell formations, and the intervening Puponga Formation consists of floodplain sediments. Paleocurrent data indicated that transport was from the south and east. The concept that all sedimentation in the Pakawau Basin is non-marine has been widely accepted since the work of Titheridge. 
The first of the New Zealand Geological Survey's Cretaceous-Cenozoic Basin Studies was on the West Coast Region (Nathan and others 1986). This volume covers the entire West Coast of the South Island, including the Pakawau area. Nathan and others accepted the modifications of Bishop (1971) and Titheridge (1977) to the Suggate nomenclature. They also recognised, from petroleum exploration data, that the tectonic depression which controlled the deposition of Pakawau Group sediments extends offshore to the north of the peninsula.

Increased coal exploration after 1980 resulted in a number of unpublished coal exploration reports, including: Wells (1984a, 1984b), who presented reviews of the region and of the Puponga Coalfield; Bussell (1985), who presented the results of field mapping around the shores of Whanganui Inlet; BHP Exploration Department (1985a, b, and c), which presented the results of coal exploration boreholes in the Mangarakau area; Hancock and Associates (1987), who presented the results of limited field studies; and Collen (1987), who commented on the significance of the Cape Farewell-1 petroleum exploration well to coal exploration in the region.

None of these reports presents a stratigraphic column that differs significantly from those of Suggate (1956) or Bishop (1971). Structurally, the most important contribution in these coal reports is the air-photo interpretation of Wells (1984b). This interpretation theorises that the lineation pattern visible on aerial photographs, and mapped by Bishop (1971) as faults, may be caused by a set of mega-joints, possibly formed during folding of the Wakamarama Anticline.

The real significance of the coal exploration reports is as a source of new data on the outcrop and subsurface geology of the region. Of particular value are the reports of BHP Exploration Department (1985c) and Bussell (1985).

Petroleum exploration in the last few decades has also yielded considerable data on the geology of the Pakawau Basin. Offshore the basin has been covered by several seismic reflection surveys and interpretations (for example Mollah 1976, 
Purcell 1983, 1984). Two offshore wells have been drilled in the basin: Cook-1

(New Zealand Aquitaine Petroleum 1970) and Fresne- 1 (New Zealand Aquitaine Petroleum 1976). One onshore petroleum exploration well, Cape Farewell-1 (Carter and Kintaner 1987) has been drilled from near the tip of the peninsula, and deviated to an offshore bottom-hole location. The results of petroleum and coal exploration will be discussed in detail in later sections, as they form the most important source of data for investigation of the basin.

\subsection{Stratigraphy of the Pakawau Basin}

Petroleum explorers have applied the term Pakawau Group, informally, for several years in subsurface Taranaki Basin stratigraphy to non-marine coalmeasure sediments of late Cretaceous through Paleocene age (for example, Pilaar and Wakefield 1978). During the 1980's, however, the term Pakawau Group came to denote only the Cretaceous portion of those sediments (for example Shell Oil Company 1987, Collen 1988), with Paleogene non-marine strata being assigned to the Kapuni Group of Palmer (1985). Purcell (1986) pointed out this trend in a review paper on West Coast coal basins. The use in recent literature of the Cretaceous/Tertiary boundary to separate the Pakawau and Kapuni groups is largely for convenience, as the two groups are similar, overlap on many stratigraphic diagrams (for example Pilaar and Wakefield 1978, and Palmer 1985), and are largely subsurface. This is also a convenient definition for seismic reflection mapping as the Cretaceous/Tertiary boundary is a mappable seismic horizon (for example, Knox 1982, Shell Oil Company 1987, Thrasher 1988, and Thrasher and Cahill 1990).

In 1988, King formalized this stratigraphic nomenclature for subsurface Taranaki Basin. He also redefined the Pakawau region stratigraphy in terms of the Taranaki Basin system. The Farewell Formation of northwest Nelson became the basal formation of the Kapuni Group, with a restricted Paleocene age. This usage has been followed by subsequent researchers in Taranaki Basin. For 
example Robinson (1989) assigns conglomeratic Paleocene strata encountered in the Kupe South Field to the Farewell Formation, within the Kapuni Group.

Applying this nomenclature to the outcrop area in Northwest Nelson is difficult, however, as the Cretaceous/Tertiary boundary has not been precisely located within that sedimentary sequence. That the uppermost beds of Suggate's (1956) Pakawau Group were Paleocene has long been recognized, and Raine (1984) determined on palynological evidence that the "uppermost part (Farewell Formation)" was Tertiary, but could not ascertain the boundary. In more detailed work Raine (1989) determined that the boundary "lies within the lower $100 \mathrm{~m}$ of the Wharariki Formation, or in the upper $50 \mathrm{~m}$ of the Puponga Formation." Based on this work and the stratigraphic nomenclature of King (1988), it seems reasonable to tentatively adopt the top of the Puponga "Formation" (referred to in the present study as the Puponga Member of the North Cape Formation) as the contact between the Pakawau and Kapuni groups.

The stratigraphy used in this study is an extension of that recommended by King (1988) (see Figure 1.2). The main variation in the present work is in subdividing the lower portion of the Pakawau Group, which King (1988) left undifferentiated, into formations based on data from petroleum exploration and onshore coal exploration. The stratigraphy used for this study is as follows:

\section{Ngatoro Group}

The Ngatoro Group (after King 1988, and incorporating the Westhaven Group of Bishop 1971) is composed of the calcareous marine strata of Oligocene to early Miocene age which, in Pakawau Basin, unconformably overlie non-marine beds of the Kapuni Group. The Ngatoro Group is ubiquitous in Taranaki Basin, is post-rift, and forms the "roof" of the sedimentary sequences which are the focus of this study. Because of its ubiquity and identifiable seismic reflection signature the base of the Ngatoro Group is a convenient datum surface from 
which to reference subsurface interpretations (for example, figures 4.5 and 4.6 have been constructed using the base of the Ngatoro Group as a reference datum). Although not included in King's original definition of the Ngatoro Group, the group is taken in the present study to include the Westhaven Group formations of Bishop (1971): Abel Head Formation; Takaka Limestone; and Kaipuke Siltstone. These three formations are synonymous with the Otaraoa, Tikorangi and Taimana formations of Taranaki Basin.

\section{Kapuni Group}

The Kapuni Group was upgraded from the Kapuni Formation by Palmer (1985) to formalize a grouping of Paleocene and Eocene coal measure formations in the subsurface of Taranaki Basin. These strata had long been grouped informally by petroleum explorers. King (1988) expanded the Kapuni Group to include the coal measure sequences of similar age in northwest Nelson. The only Kapuni Group formation of immediate interest to the study of the Pakawau Basin is the Paleocene-aged Farewell Formation.

Farewell Formation (after Titheridge 1977, incorporating the Wharariki Formation of Suggate 1956): Composed of coarse sandstone and conglomerate, with minor siltstone and coal, this terrestrial unit is up to 400 metres thick in the Pakawau region. In the northern parts of the peninsula it rests, with apparent conformity, on Cretaceous Pakawau Group. To the south the Farewell Formation rests directly on the undulating basement surface.

Although King assigned the Farewell Formation to the Kapuni Group, this assignment is based on age rather than facies or geometric relationships and is difficult to justify on the basis of outcrop observations of apparent conformity and lithologic similarity to the underlying Pakawau Group. The Farewell Formation may in future be reassigned to the Pakawau Group, but this problem was not addressed as a part of the present study. Similarly, the incorporation 
by Titheridge (1977) of the Wharariki Formation of Suggate (1956) into the Farewell Formation was not addressed, but needs to be evaluated.

\section{Pakawau Group}

King (1988) restricted the Pakawau Group to the Cretaceous, non-marine sediments of Taranaki Basin. More recent palynological work (Wilson 1991a, 1991b) has revealed a marine influence in portions of the previously defined Pakawau Group, so the definition is here expanded to include marine facies. The upper contact of the Pakawau Group correlates with the "top Cretaceous" seismic reflection horizon from Taranaki Basin. Although the term is applied throughout Taranaki Basin, the only outcrop of Pakawau Group rocks is in Northwest Nelson. In the outcrop area, the group can be divided into four units: The North Cape Formation and its Puponga Member, and the Rakopi Formation and its Otimataura Conglomerate Member.

North Cape Formation: This formation is expanded from that of Suggate (1956) to denote a thick (up to $1500 \mathrm{~m}$ ) sequence of conglomerate, sandstone, and siltstone, with only minor coal. The formation includes the informal "Pillar Formation" reported in the Cape Farewell-1 well completion report (Carter and Kintaner 1987). The Puponga Member contains the uppermost, coal-bearing beds of the formation. Titheridge (1977) considered the North Cape Formation to have been deposited in a braided stream environment, but recently analyzed outcrop samples (Wilson 1991a) have yielded dinoflagellates, indicating a marine to coastal/paralic environment of deposition. Sedimentological evidence for tidally-influenced deposition within the North Cape Formation is reviewed by Wizevich and others (in press). Figure 4.4 is a measured section presented by Wizevich and others showing sedimentary features, such as ripple crosslaminations and opposing cross-beds, consistent with tidally-influenced marine deposition. 


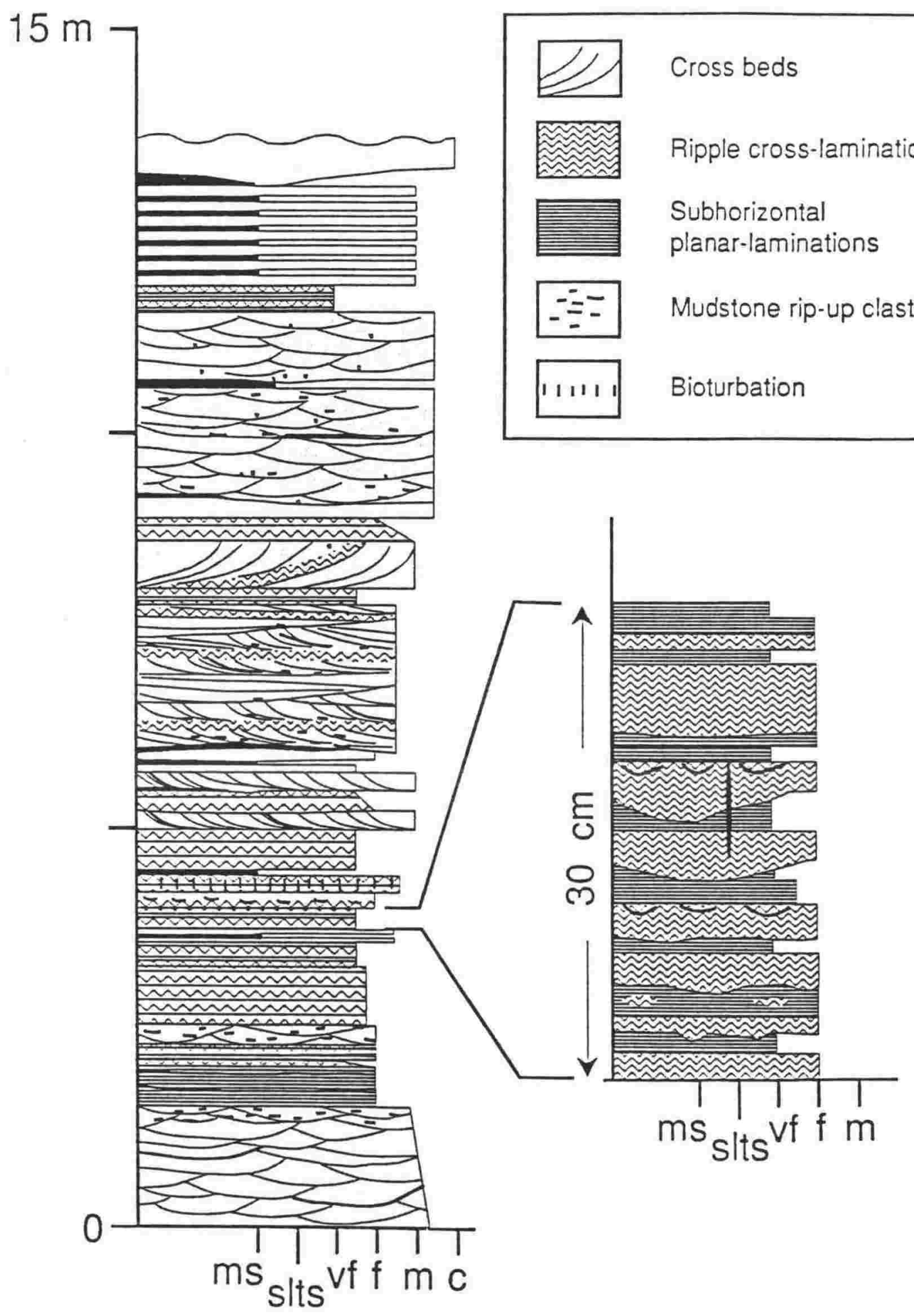

Figure 4.4 Measured section from the Mangarakau locality (after Wizevich and others, in press). See Figure 4.1 for location. 
Puponga Member (previously Puponga Formation (Suggate 1956)): This is the uppermost unit of the North Cape Formation in the outcrop area. The member is generally less than $100 \mathrm{~m}$ thick, and includes the coal-bearing rocks previously mined in the Puponga vicinity. The Puponga Member is composed of alternating fine to medium sandstones and siltstones, with coal seams and minor conglomerate. The unit may be laterally discontinuous, although Titheridge (1977) and Bussell (1985) have identified it around the western shores of Whanganui Inlet. Coal measures of probable latest-Cretaceous age in Fresne-1 were assigned to the Puponga Formation by King (1988).

Titheridge (1977) determined the Puponga Formation to have been deposited in a floodplain environment. In outcrops around the southern end of Whanganui Inlet (for example at the end of the point just south of Mangarakau Stream) the unit consists of thin coals and carbonaceous siltstones interbedded with muddy sandstone. The sandstone beds are rippled and contain mud drapes, possibly indicating deposition under tidal influence. A paralic environment of deposition is preferred here for the Puponga Member.

Rakopi Formation (new name): This formation is named for the Rakopi Borehole (Figure 4.3), a coal exploration hole drilled in 1915 at Rakopi on Whanganui Inlet (Suggate in Wellman 1950). The formation is equivalent to the informal "Lower Part" of the Pakawau Group identified by Harrison and Van Oyen (1969) and the informal "Green Hills Formation" reported in the Cape Farewell-1 well completion report (Carter and Kintaner 1987). The name "Green Hills Formation" is here rejected because the formation is not present along the course of Green Hills Stream, and, in addition, Green Hills Stream is given by Harrison and Van Oyen (1969) as a locality for their Pakawau Group "Upper part" (equivalent to the Farewell and North Cape formations). The lowermost conglomerate of the Rakopi Formation is here referred to as the Otimataura Conglomerate Member. 
Content: The Rakopi Formation is a coal measure sequence of interbedded sandstone, carbonaceous siltstone and mudstone, and thin coal, more than $1500 \mathrm{~m}$ thick underlying the North Cape Formation. The formation is believed to be wholly terrestrial.

Distribution and type section: Rakopi Formation strata are recorded in the Cape Farewell-1 well, the Rakopi Bore, and boleholes UC-1, 2, and 3 (Enclosure 4.1) (BHP Exploration Dept 1985c). The formation also outcrops along the Pakawau to Whanganui Inlet road, along the upper reaches of the Patarau River and in the courses of Muddy Creek and the Wairoa River, on the eastern side of Whanganui Inlet. The formation is widespread in the Pakawau Graben, and probably underlies most of the outcrop area. Unfortunately, outcrop of the formation tends to be discontinuous, poorly exposed, weathered, and unsuitable for type-section designation. The type section is here selected as the interval from $1160 \mathrm{~m}$ to $2690 \mathrm{~m}$ AHBKB in Cape Farewell-1 (surface location $2484444 \mathrm{~m}$ East, $6078127 \mathrm{~m}$ North). This has been selected as it is the most continuous observation of the unit and allows for extrapolation into other subsurface data sets (such as wire-line log and seismic reflection data).

Otimataura Conglomerate Member: After Bishop (1971). Otimataura Conglomerate Member is here used to denote a basal conglomerate sometimes present at the bottom of the Pakawau Group section. The distribution of the conglomerate is uncertain, but it has been found in the Rakopi Borehole and possibly in Cape Farewell-1 (2690 m to TD). Bishop (1971) maps exposure of the member along much of the southeastern edge of Pakawau Group outcrop and records a maximum thickness of over $300 \mathrm{~m}$ in the type section along Otimataura Stream.

The Otimataura Conglomerate Member is currently more accessible in Coal Creek, a tributary of Otimataura Stream, than in Otimataura Stream itself. The courses of both Coal Creek and Otimataura Stream are through vertical-walled gorges cut into the near-flat-lying conglomerate. In Coal Creek the Otimataura 
Conglomerate rests on Onekaka Schist (Bishop 1971) basement rocks. Immediately overlying basement is a schist-clast breccia, approximately $20 \mathrm{~m}$ thick, with interbedded sandstone, in a dark red to purple matrix. This unit is well-bedded in places, with sharp, erosive internal surfaces. Clasts are up to 50 $\mathrm{cm}$ and are primarily angular, although some are well rounded, and are mainly schist apparently derived from the local basement rock. In nearby Otimataura Stream this unit is thinner, and is separated from the overlying conglomerate by a few metres of mudstone and coal beds.

In Coal Creek the lower unit of purple-coloured sandstone and breccia grades upward into a massive clast-supported, brown to tan conglomerate which forms cliffs over $100 \mathrm{~m}$ high. This upper unit contains well-rounded, coble-sized clasts from a wide range of mainly-quartzose basement rock types, including granite. The matrix is poorly-sorted quartz sand, and there are occasional thin sand lenses within the conglomerate. This upper portion of the Otimataura Conglomerate is more indurated than the lower portion. Clast imbrication is weak and variable, but indicates flow to the north. The wide range of clast lithologies, well rounded clasts and northward flow may indicate that this unit was deposited by major trunk drainage down the axis of the early Pakawau Basin, compared to more local deposition for the lower schist-breccia unit.

\section{Basement}

The informal term "basement" is used in this study to denote those rocks lying beneath the major unconformity surface upon which the Pakawau Group and later sediments were deposited. In Pakawau Basin these are Paleozoic metamorphic, submetamorphic and granitic rocks (Bishop 1968, 1971). These rocks were subjected to subaerial erosion, forming an erosion surface of subdued relief prior to deposition of the Cretaceous through Cenozoic sedimentary sequence. This surface corresponds to the "seismic basement" surface interpreted on seismic reflection profiles from the offshore portion of 
the Pakawau Basin, and throughout the Taranaki Basin region (Thrasher and Cahill 1990).

\subsection{Well and outcrop correlation}

Correlating specific sequences into the stratigraphy detailed in the preceeding section is generally straightforward. The geophysical mapping of Thrasher and Cahill (1990) and the present study (see Chapter 5) confirms the correlations between the petroleum exploration wells, and assists in the correlations of the onshore sequences. The two cross-sections of figures 4.5 and 4.6 illustrate these correlations. Logs of the onshore boreholes are shown on Enclosure 4.1.

All petroleum exploration wells, and the significant coal exploration wells, have been correlated with the outcrop sequence. Specific notes regarding these sequences are as follows:

1. Cook-1. The Rakopi Formation in this well is taken as the coal bearing sequence from $2251 \mathrm{~m}$ to TD $(2688 \mathrm{~m})$. This unit was previously referred to as the "lower coaly sandy member".

The sandy sequence overlying the Rakopi Formation was previously undated, but recent dating by Raine (Wilson 1991b) has confirmed that the section from about $1400 \mathrm{~m}$ to TD is Haumurian (latest Cretaceous) in age. The dating of Wilson (1991b) also reveals the presence of dinoflagellates, which indicate a shallow marine to nearshore environment of deposition. The sandy, non-carbonaceous sequence from $1400 \mathrm{~m}$ to $2551 \mathrm{~m}$ is therefore correlated with the North Cape Formation. This section was previously referred to as the "middle silty sandy member".

Note: Abbreviations used in this section include: Total Depth (TD), Below Kelly Bushing (BKB), and Along Hole Below Kelly Bushing (AHBKB). 


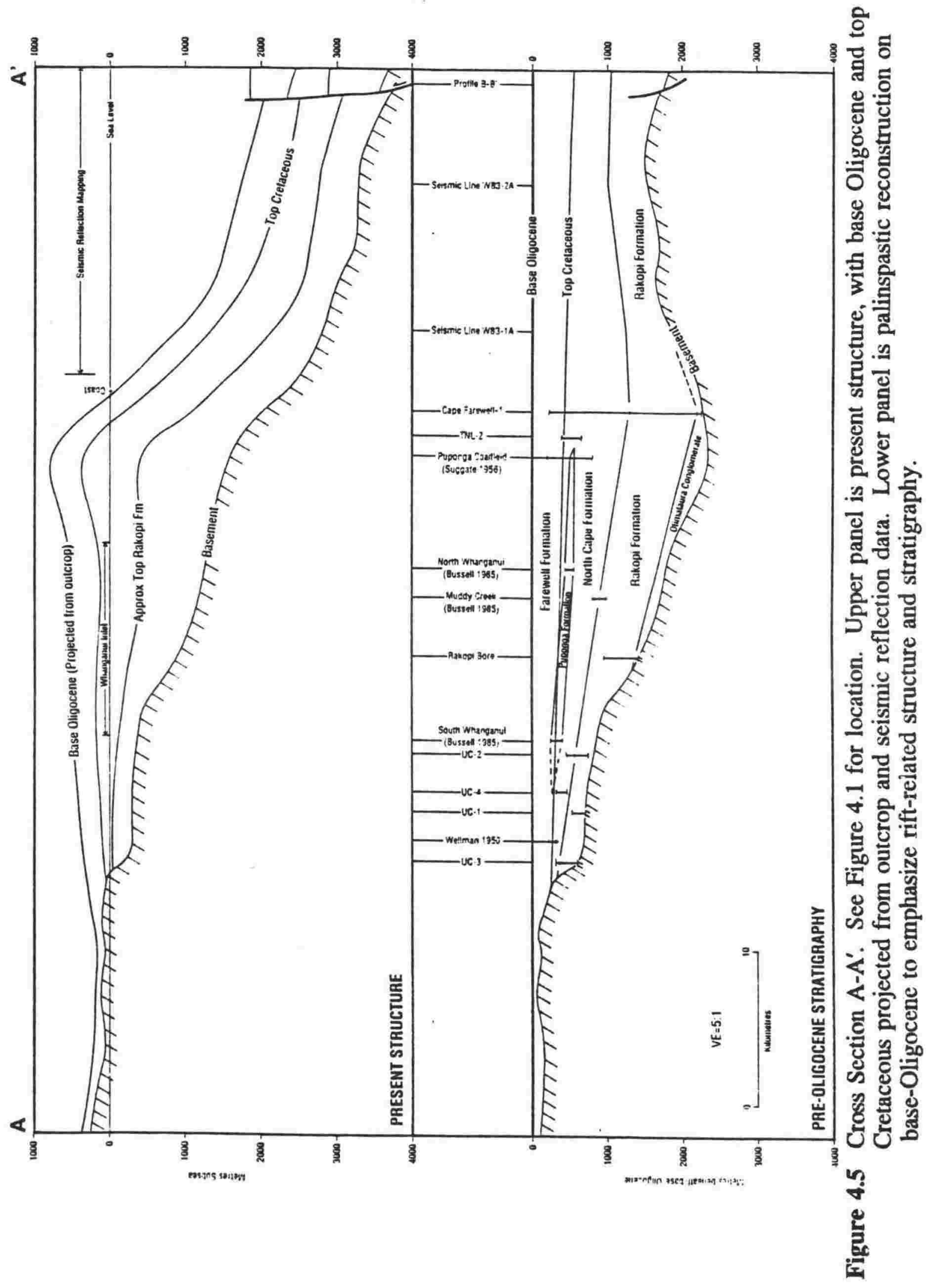




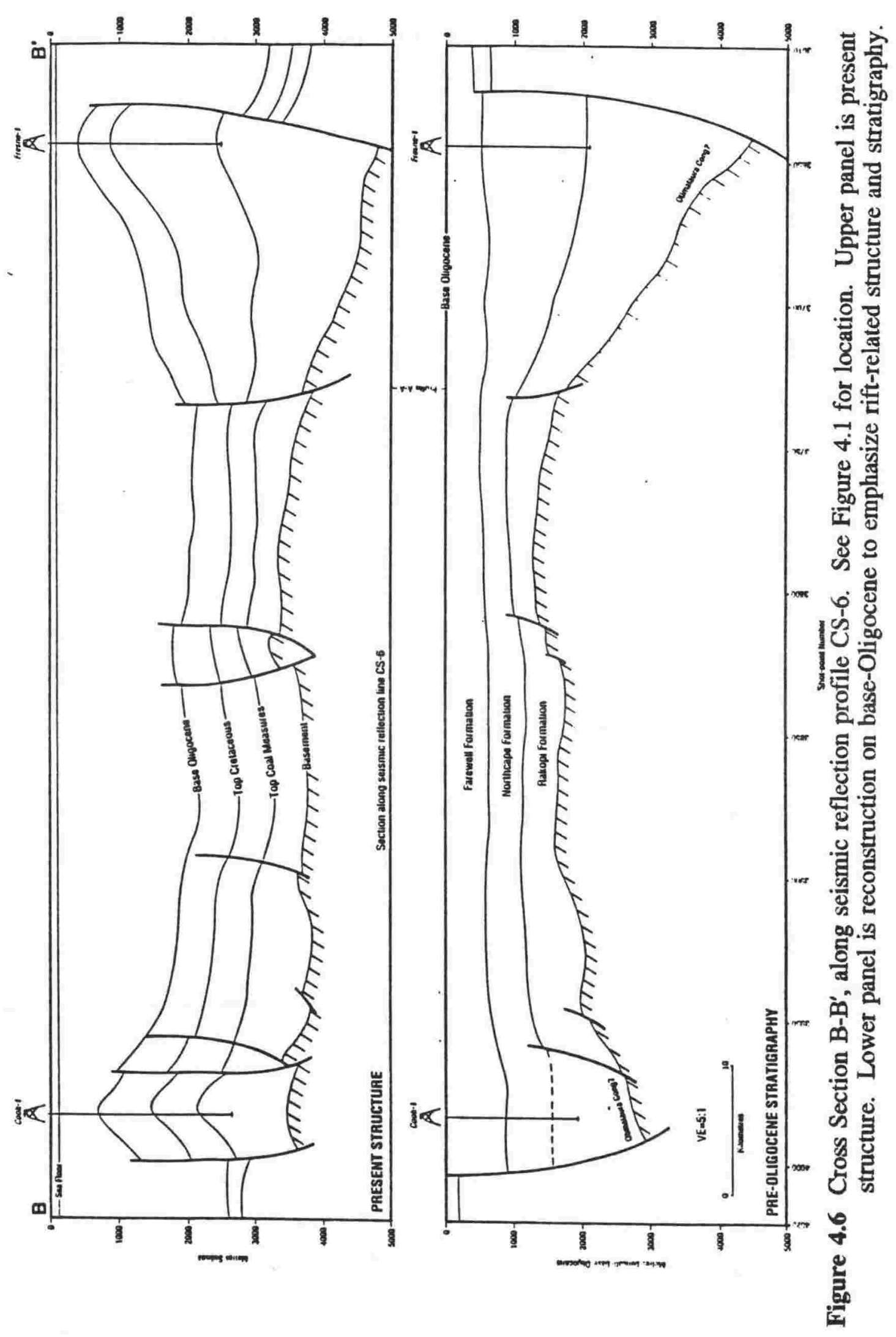


The dinoflagellate indentifications of Wilson (1991a, 1991b) include the observation that the entire North Cape sequence in Cook-1, and possibly the outcrop sequence as well, is included within the A. acutulum and $M$. druggi zones of the latest Cretaceous. The North Cape sequence may therefore be confined to the last 3 million years of the latest Cretaceous, indicating a very high sedimentation rate in a shallow marine environment.

The Paleocene sequence from $650 \mathrm{~m}$ to $1400 \mathrm{~m}$, previously called the "upper coaly and sandy member", is now correlated with the Farewell Formation.

2. Cape Farewell-1. The conglomeratic sequence in the bottom of Cape Farewell-1 (2690 $\mathrm{m}$ to TD) is here assigned to the Otimataura Conglomerate Member of the Rakopi Formation. This correlation is based on the seismic reflection intrepretation of Thrasher and Cahill (1990), which concludes that seismic basement is very near the TD of the well. This is at variance with the seismic interpretation upon which the well was based, which predicted considerable sedimentary section between TD and basement (Carter and Kintaner 1987). The seismic reflectors corresponding to this additional sedimentary section in the interpretation presented in Carter and Kintaner (1987) are interpreted in Thrasher and Cahill, and the present study, as basement and subbasement events.

The remainder of the Rakopi Formation in Cape Farewell-1 is taken as the coal bearing sequence from $1160 \mathrm{~m}$ to $2690 \mathrm{~m}$ AHBKB. This is the proposed type section for the Rakopi Formation. The original well completion report (Carter and Kintaner 1987) concluded that this interval contained rocks as old as Clarence age (mid Cretaceous). Recent redating of this sequence by Raine (written communication, see Appendix 2) does not support the ages assigned by Carter and Kintaner 
and finds a Haumurian (late Cretaceous) age for the entire Rakopi Formation.

The non-carbonaceous interval above $1160 \mathrm{~m}$ is assigned to the North Cape Formation. Carter and Kintaner erected the informal "Pillar Formation" for the lower portion of this interval, but this differentiation is not continued here because the "Pillar Formation" is not sufficiently characteristic to warrant formation status.

The top of the North Cape Formation is not identified in the well, due to sampling and dating problems in the upper few hundred metres, where the contact should lie.

3. Fresne-1. This well penetrated only $57 \mathrm{~m}$ of the Rakopi Formation, from $2447 \mathrm{~m} \mathrm{BKB}$ to TD $(2504 \mathrm{~m})$. This interval is predominantly sandstone, with several thin coal seams.

The North Cape Formation in Fresne-1 is the interval from about 923 to $2447 \mathrm{~m}$ BKB. The lower portion, from 1550 to $2447 \mathrm{~m}$, consists of conglomeratic sandstones. This is the only known occurrence of these rocks and they are here referred to as the informal Fresne Conglmerate Member. Dinoflagellate cysts recorded within the interval from 1230 to $1550 \mathrm{~m}$ (Hayward and Raine 1985) indicate a marine influence, but the presence of Cretaceous coal measures above these non-carbonaceous sediments indicates a latest Cretaceous terrestrial environment. From 923 to $1230 \mathrm{~m}$ is a coal measure sequence here assigned to the Puponga Member.

4. Rakopi Bore. This coal exploration bore hole was drilled in 1915 near the township of Rakopi. Figure 4.3 is a lithological log of the hole. This well was spudded in outcrop of Rakopi Formation, and contains about $400 \mathrm{~m}$ of that formation. The $20 \mathrm{~m}$ of conglomerate and grit 
which rest on granitic basement are assigned to the Otimataura Conglomerate Member.

5. UC1, UC2, UC3, and UC4 coal exploration wells. These 4 holes were drilled in 1985 by BHP Exploration Department. They range from 150 to $300 \mathrm{~m}$ deep, and were wireline logged. Enclosure 4.1 illustrates logs of these wells, their correlations and location information.

6. Outcrop. Interbedded sequences of thin sandstone, siltstone, carbonaceous shale and coal outcrop in numerous places around the eastern shore of Whanganui Inlet and in the streams which feed into the inlet. Bussell (1985) has documented many of these sequences. They are stratigraphically lower than coal bearing sequences outcropping along the western side of the inlet or in the Puponga area, and are separated from them by a thick sequence of non-carbonaceous sandstones. This lower coal-bearing unit is assigned to the Rakopi Formation, while the overlying sandstones are assigned to the North Cape Formation. Figure 4.1 portrays the simplified geology of the region.

\subsection{Structure of the Pakawau Basin}

The Taranaki Basin maps of Thrasher and Cahill (1990) and Chapter 5 include coverage of the Pakawau Basin, which we can use to investigate the structural configuration of the basin. Of greatest significance to the Pakawau Basin are the Cretaceous and Paleogene maps. Figure 4.7 is the structure map on top Eocene for this region. In this portion of Taranaki Basin the Eocene is not commonly present, and this map represents the base of Oligocene and younger sediments (base Ngatoro Group of King 1988). Figure 4.8 is the structure on top Cretaceous, Figure 4.9 is structure on top of the Rakopi Formation, and Figure 4.10 is structure on seismic basement. 


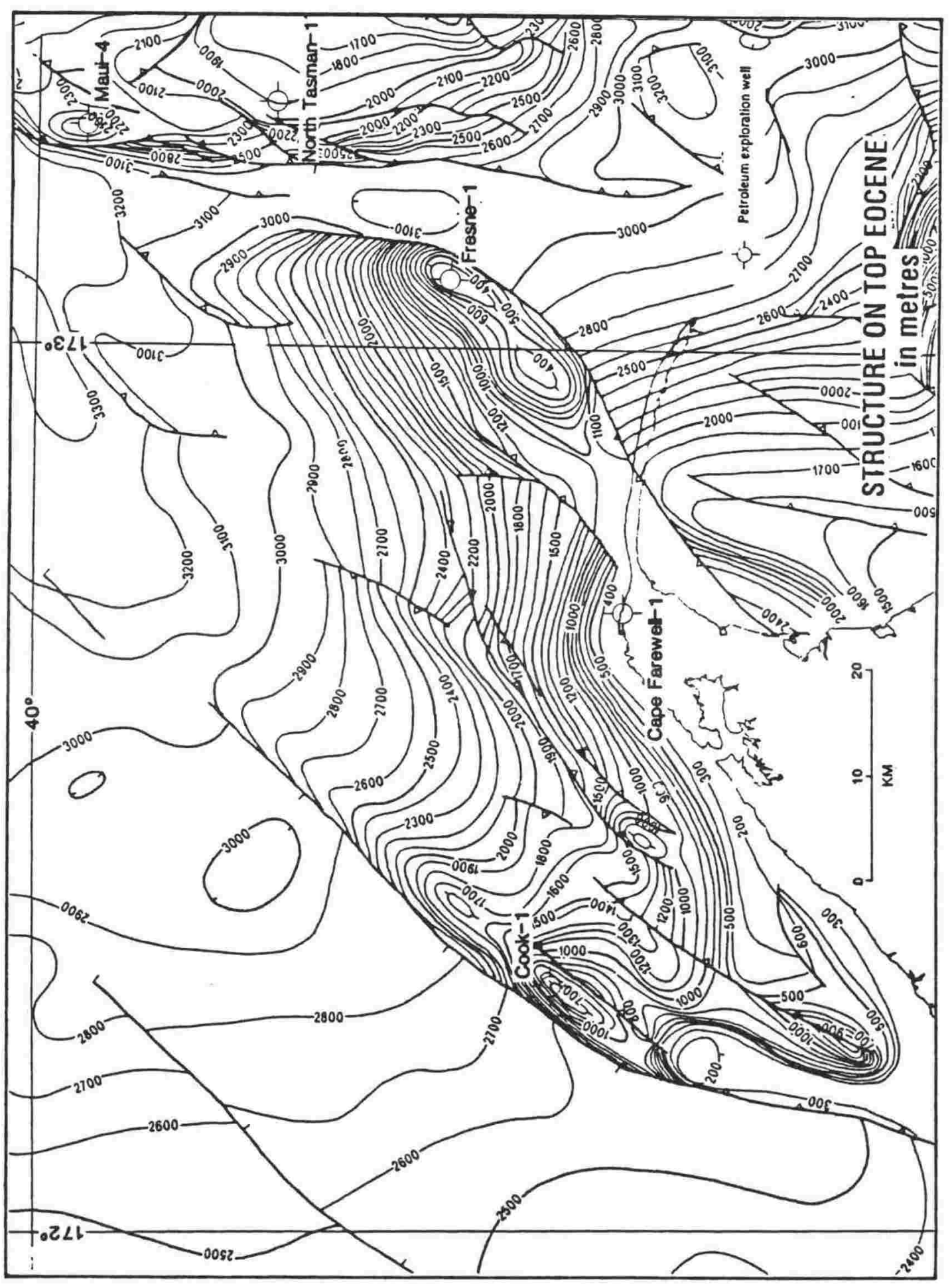

चี 


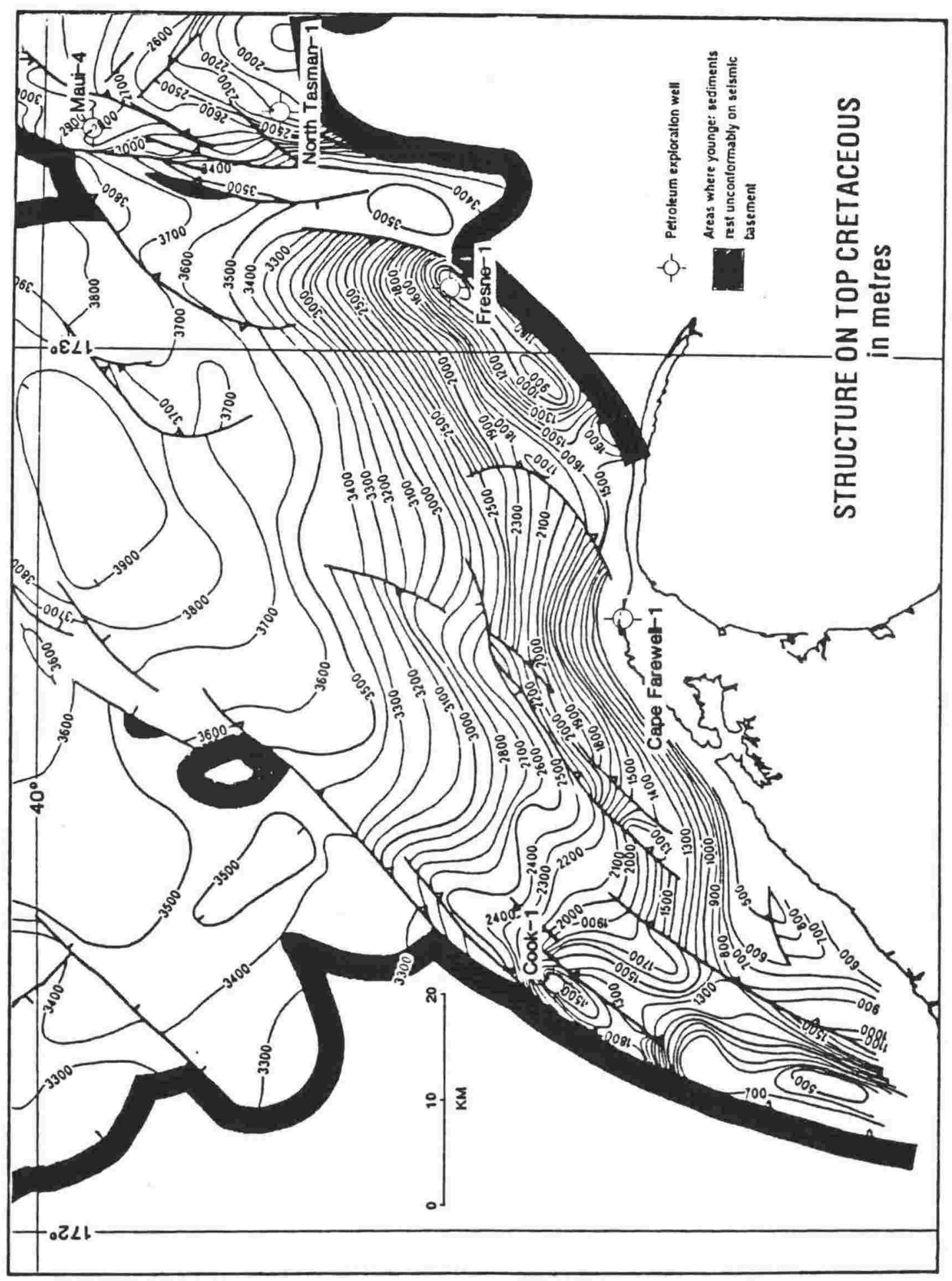

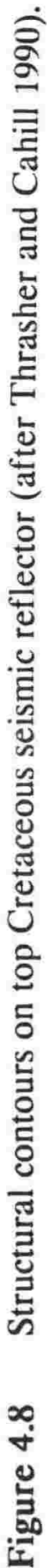




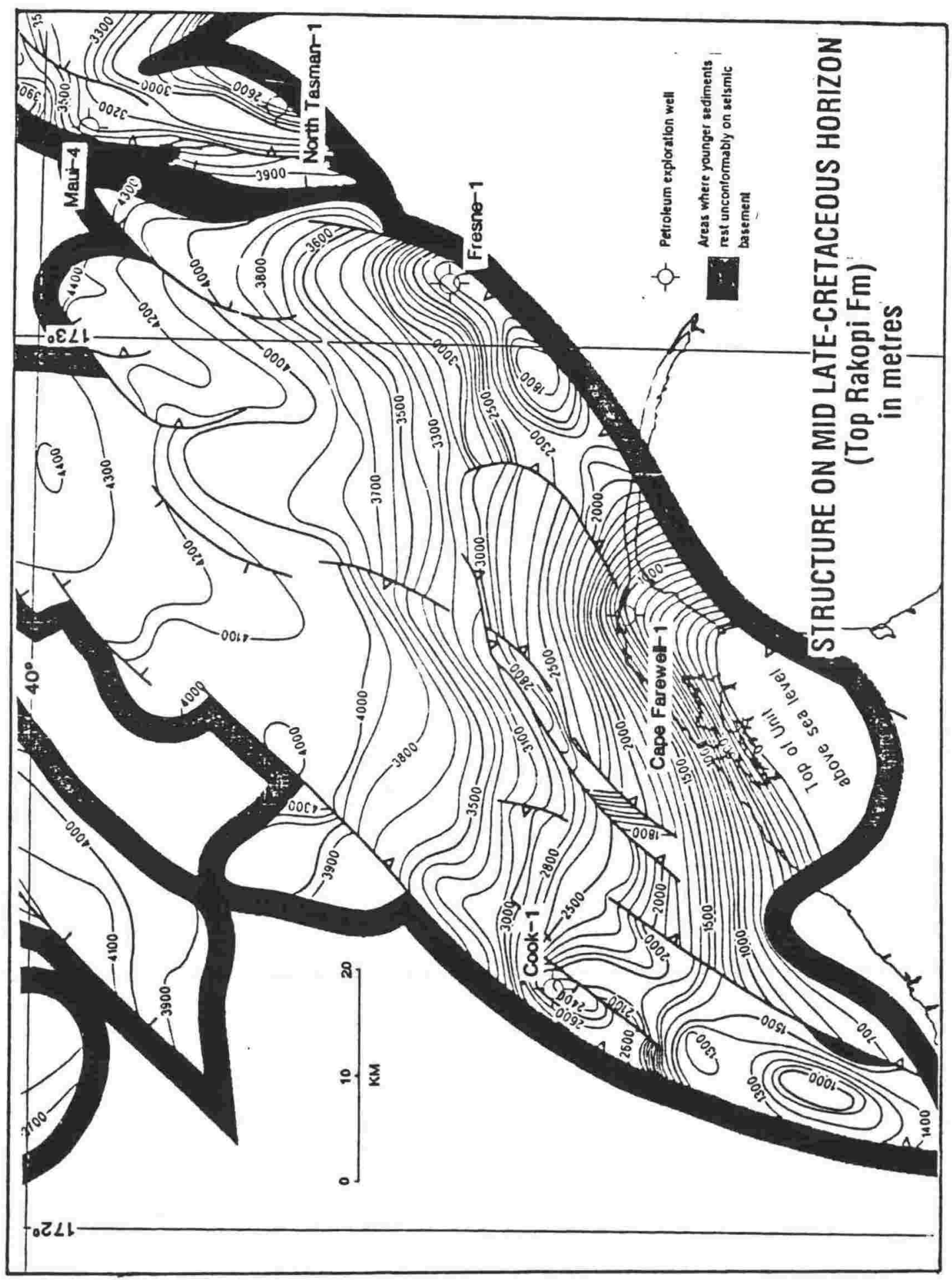

을 


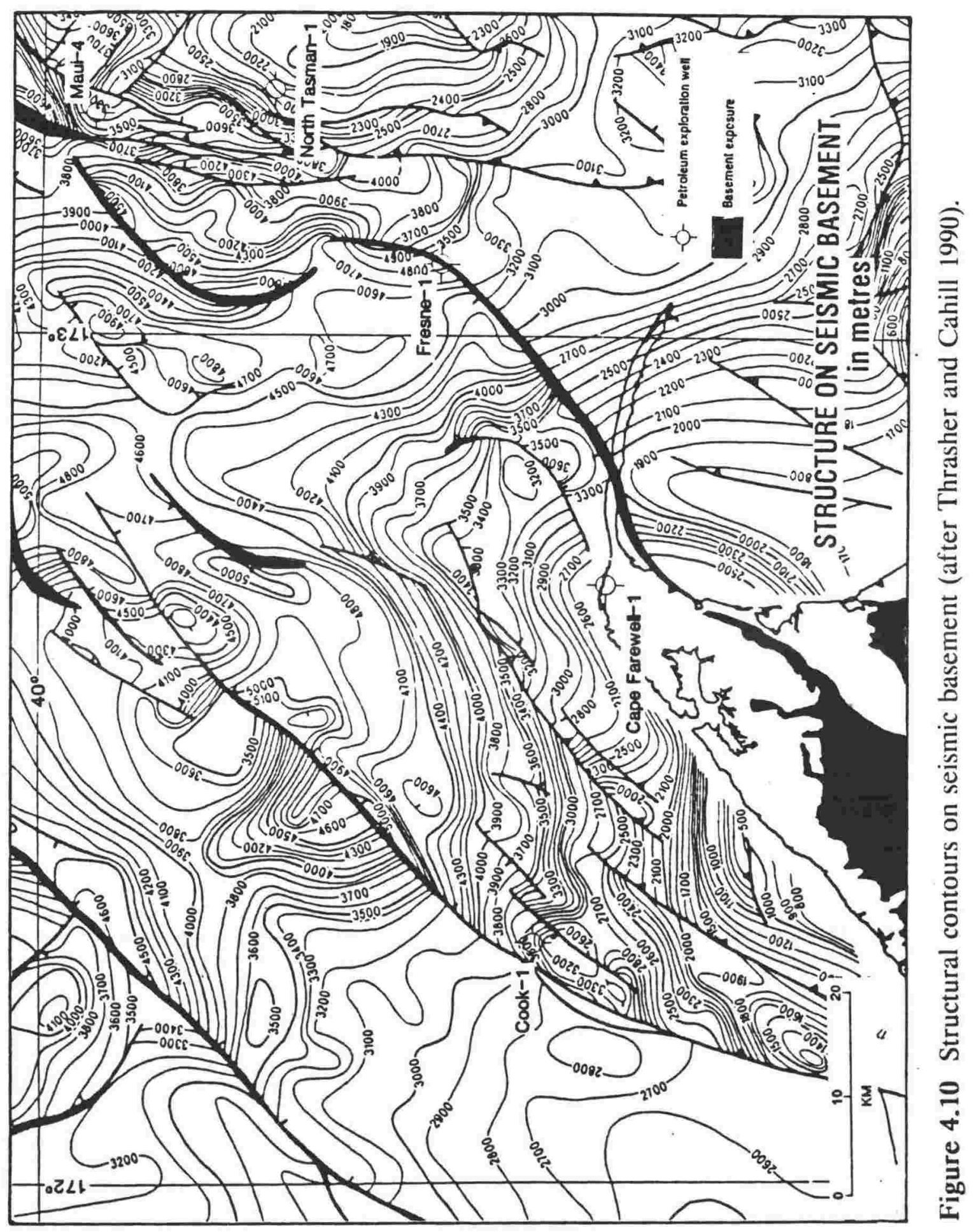


Seismic reflection data have not been acquired from the onshore portion of the Pakawau Basin. Determining the structure onshore incorporates data from several sources. For basement structure, lines of evidence include: the elevation of outcrop contacts; depths of coal and petroleum exploration wells (whether reaching basement or not); depth extrapolation of surface dips; the erosional depth of rivers and gullies; and the extrapolation of offshore contours and trends.

One other source of data on the structure of basement is the present shape of the original basement surface upon which Pakawau Basin sediments were deposited. The shape of this surface immediately prior to the present phase of erosion can be estimated using the peneplain reconstruction techniques of Wellman (1940). This method uses the upward extrapolation of present sediment/basement contacts, combined with the heights of summits, and accordant ridges and shoulders, of the exposed basement to produce a smooth contour surface. The assumption implicit in this method is that summits, ridges and shoulders exhibiting maximum local elevation have had little or no Quaternary erosion since the removal of the sedimentary cover. If this assumption is valid, then such a contour map should reflect the pre-erosion basement surface.

Figure 4.11 is a structure map with $500 \mathrm{~m}$ contour interval of the basement surface using all of the information mentioned above. The area of present basement outcrop is contoured as the reconstructed peneplain surface (dashed contours). Note the basement is a smooth, northwest-dipping surface which shows only slight roll-over into the Wakamarama Fault.

The only other surface for which the presently mapped onshore geology can supply any control is the base of the Oligocene Ngatoro Group. This equates with the offshore "top Eocene" seismic reflection surface. Onshore this is the easily recognizable contact between the sands and conglomerates of the Paleocene Farewell Formation and the overlying marine beds. Contours on the 


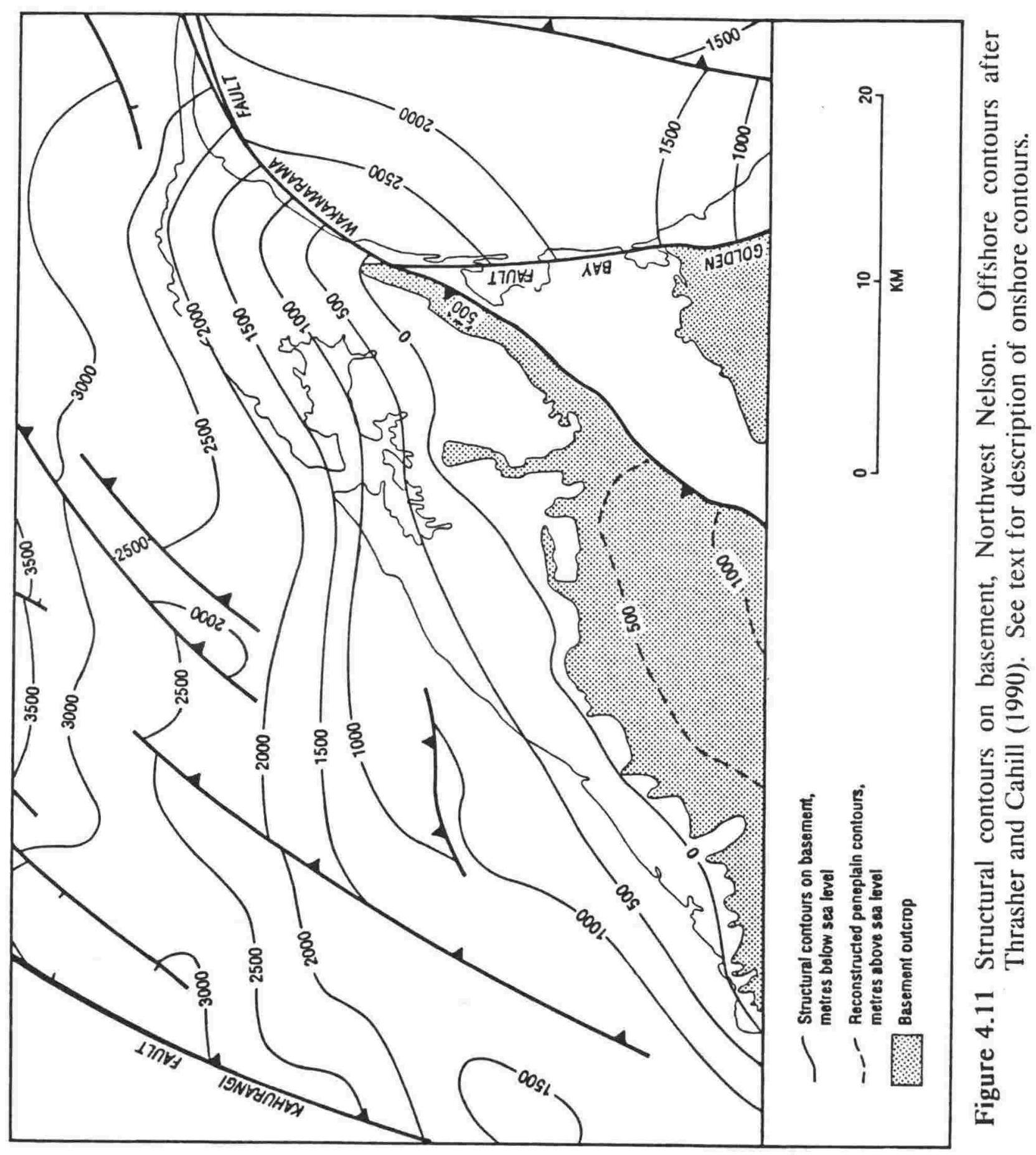


contact can be extrapolated down-dip to connect smoothly with the offshore seismic-reflection horizon (Figure 4.7). Unfortunately, up-dip extrapolation is only possible with confidence for a short distance, because the attitude of the Ngatoro Group beds is slightly different from the attitude of the underlying beds. The up-dip extrapolation shown on Figure 4.5 has only been attempted far enough to estimate the intersection of this surface with the A-to-A' cross-section (see Figure 4.1 for location of the cross-section).

As discussed previously, the contact between the Kapuni Group and underlying Pakawau Group is presently defined as at the Cretaceous/Tertiary boundary. Because this boundary has not been located onshore, it is not presently a mappable contact. From offshore seismic data, tied to petroleum exploration wells to the north and east, it is known that the thickness of the Paleocene-Eocene sequence thins from about $500 \mathrm{~m}$ near Cape Farewell to less than $300 \mathrm{~m}$ off the Paturau River Mouth (Figure 4.12). The approximate location of the Cretaceous/Tertiary boundary onshore can be estimated by projecting that thickness trend onshore and hanging it beneath the up-dip extrapolation of the base-Ngatoro Group contact. The top Cretaceous (sea-level) contact shown on Figure 4.1 as the contact separating the North Cape and Farewell formations was constructed in this way. The position of this contact is tentative and needs to be confirmed and improved by onshore mapping, stratigraphic and paleontological studies.

From the structural evidence discussed above, two cross sections have been constructed to illustrate the subsurface geometry of the basin. Cross section A-A' (Figure 4.5) is along the plunge of the basin, and is constructed to tie the stratigraphic detail available from the coal exploration wells in the Mangarakau area with the Cape Farewell-1 petroleum exploration well. The section then continues northeast until intersecting cross section B-B' (Figure 4.6). This second section is across the basin from the Kahurangi Fault to the Wakamarama Fault, and passes through the Cook-1 and Fresne-1 petroleum exploration wells. Section B-B' is also along seismic reflection profile CS-6 illustrated in Figure 


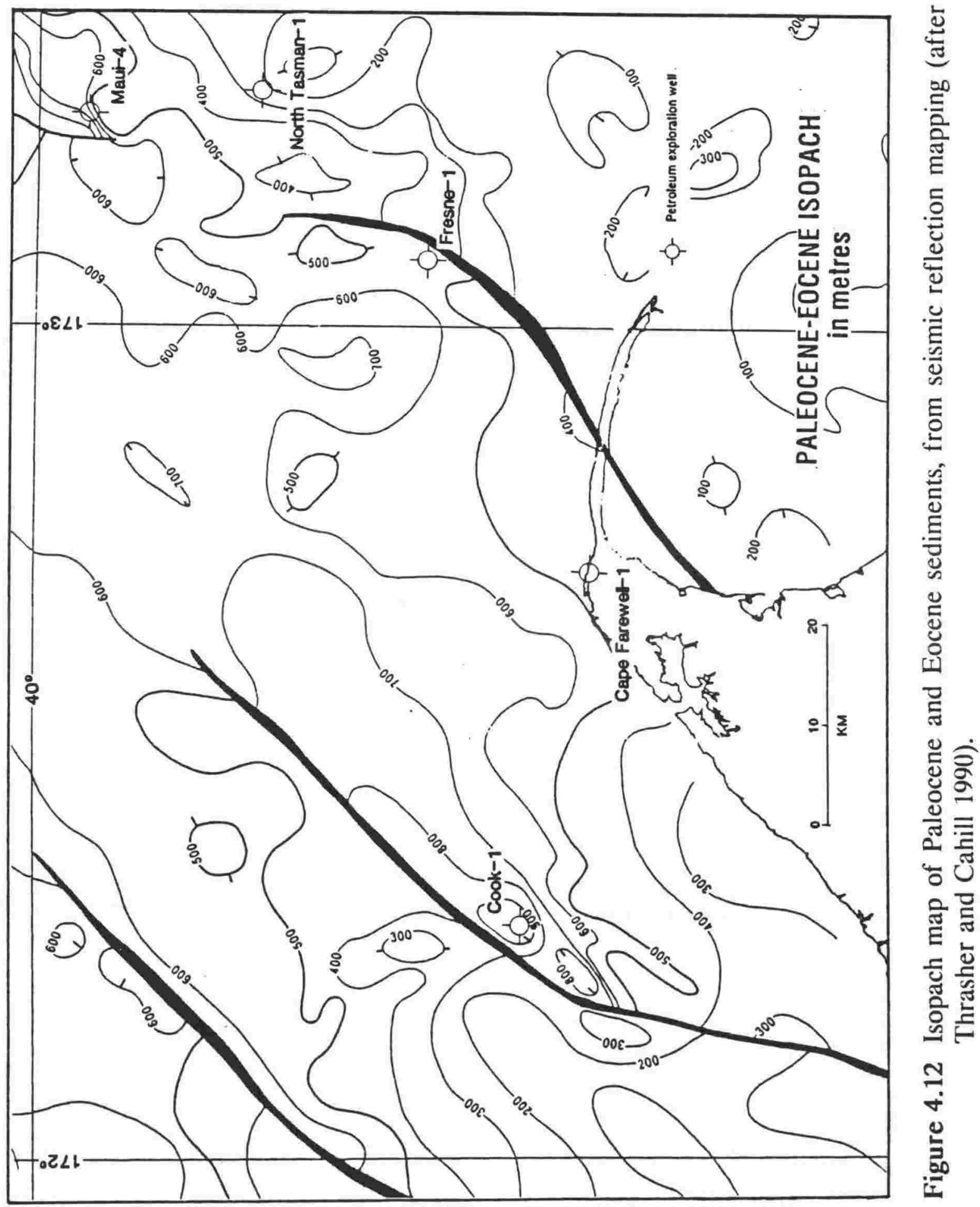


4.13. These three figures $(4.5,4.6$ and 4.13$)$ are all presented in two forms: the top portion of each figure is a present-day structural profile and the lower portion is a reconstruction of the profile at the time of the Eocene-Oligocene boundary. Note that these are not balanced structural sections, but merely palinspastic reconstructions to illustrate the Cretaceous and Paleogene structure and stratigraphy of the region.

Figure 4.14 is a close-up portion of seismic line CS-6. This line illustrates the seismic reflection character of the sedimentary sequence in the basin. Note especially the distinctive character of the top Rakopi Formation coal measures. This is an easily mappable reflection horizon throughout much of the offshore Pakawau Basin, becoming more difficult to interpret only in the proximity of the major bounding faults.

\subsection{Deformation history}

The structural history of the Pakawau Basin can be deduced from the maps and cross sections presented above. The basin first formed as an extensional basin in the late Cretaceous. This extension was shown in Chapter 3 to probably be an obliquely extensional transform that accommodated the opening of the New Caledonia Basin to the north. The individual basins along this rift trend, such as the Pakawau Basin, would have opened in response to sinistral, oblique shear.

By latest Cretaceous the eastern part of the basin was firmly established as a half-graben, controlled by down-to-the-west normal motion along the Wakamarama Fault. This half-graben plunged to the northeast from the present outcrop area, with Wakamarama Fault offset increasing in that direction. Seismic reflection data show the Cretaceous offset on the fault in the vicinity of the Fresne- 1 well to have been about $4000 \mathrm{~m}$. The northeastward plunge of the graben is illustrated in Figure 4.5, which shows the Rakopi and North Cape 


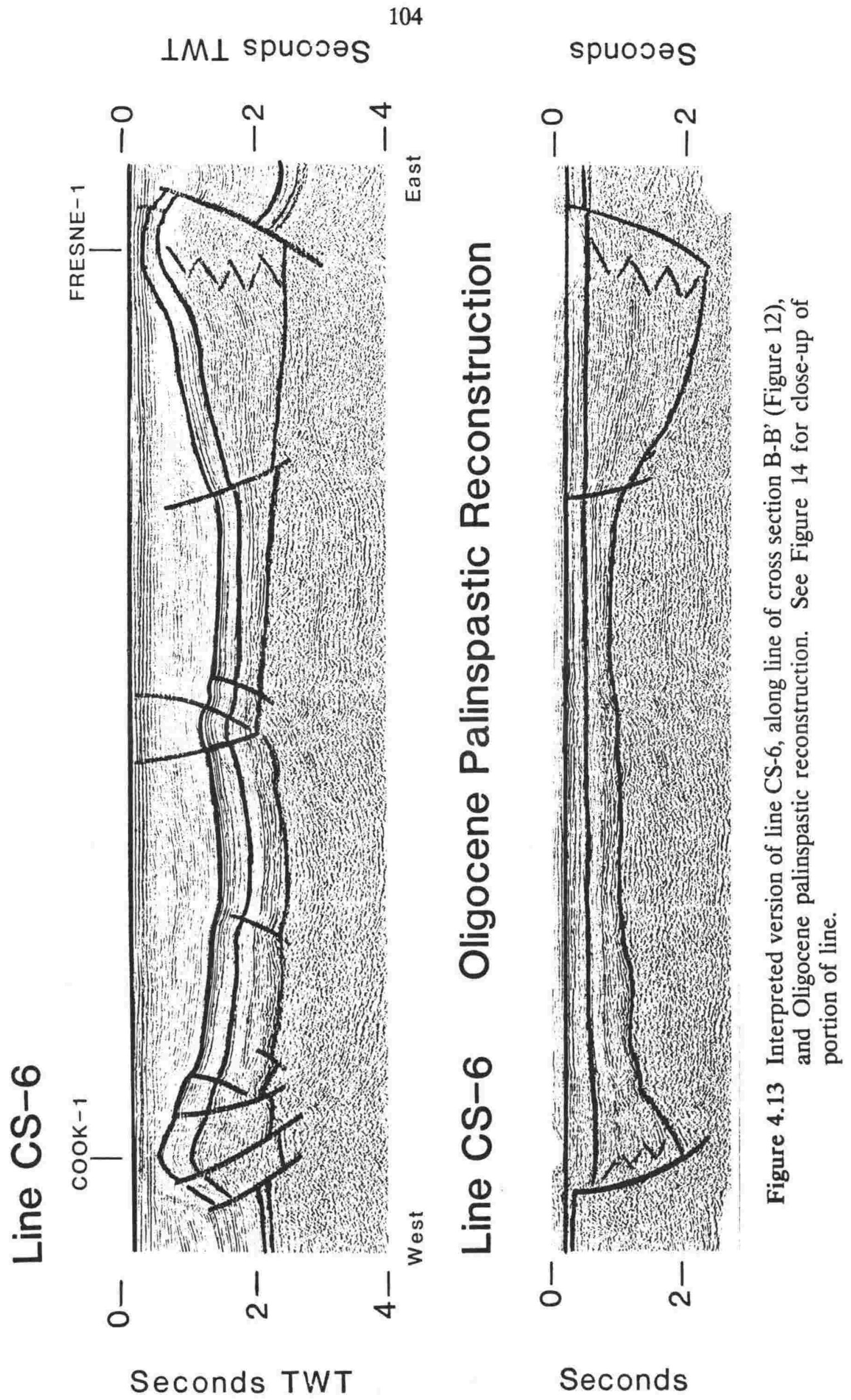




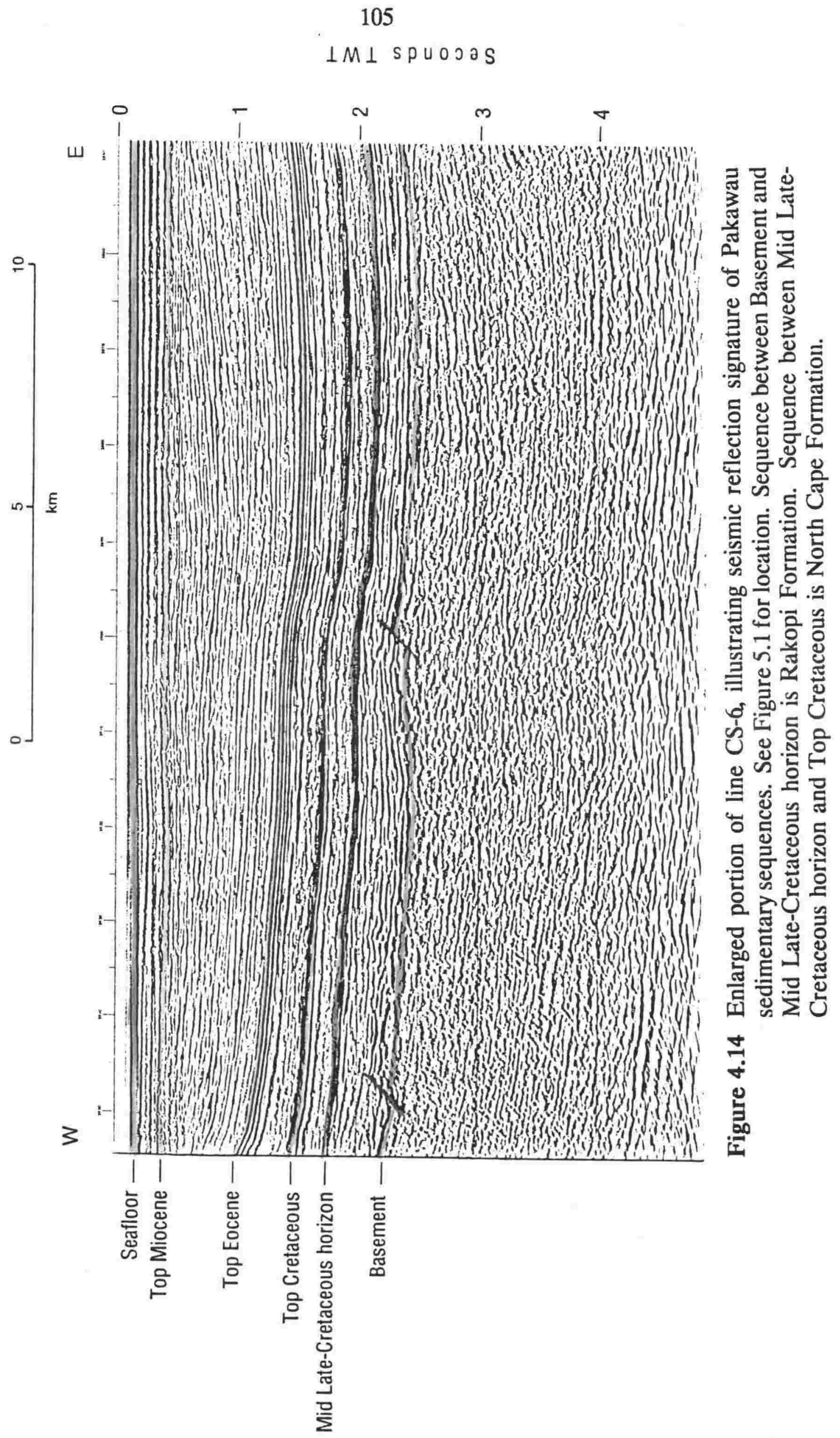


formations thickening northwards from their basement pinchouts towards the Cape Farewell-1 well. This plunge continues along the fault toward the Fresne-1 well offshore.

Coincident with normal motion along the Wakamarama Fault, a mirror-image half-graben was forming to the west, controlled by down-to-the-east normal motion on the Kahurangi Fault. Both of these grabens are illustrated in figures 4.6 and 4.13, and together make up the Pakawau Basin. Seismic line CS-6 (Figure 4.13) shows the strata to be continuous between the two grabens. The Wakamarama Fault had considerably more throw during the late Cretaceous than had the Kahurangi Fault, but no information is available on the relative timing of fault initiation.

Most maps of the Pakawau Basin produced by interpretation of geophysical data portray the Kahurangi and Wakamarama Faults as being long continuous features. The maps included in this study (for example, figures 4.7 through 4.10) show these two faults as continuous traces. Detailed mapping of active rifts shows such long traces to be very rare. Many apparently-continuous basinmargin faults are composed of en-echelon fault families with most individual traces of the order of 10 to $15 \mathrm{~km}$ long (Jackson and White 1989). The Basin and Range Province of western North America shows this trend well (for example, see Bruhn and others 1987), as does the region of active rift-related faults of Greece (Roberts and Jackson 1991). The en-echelon fault steps, often with only a few hundred metres offset, are common places for drainage systems to cross the fault scarp, and hence provide a locus for sedimentary input into subsiding basins.

Given the limitations of subsurface geophysical mapping, especially where line spacing is great ( 5 to $10 \mathrm{~km}$ for the present study) and rift-related normal faults have been reactivated under compression, there is a significant likelihood of oversimplifing the mapping of fault traces. The traces of both the Kahurangi Fault and Wakamarama Fault shown on the maps which accompany this report 
are possibly oversimplified, and their late Cretaceous rift motion may have been along numerous en-echelon traces.

Both the Kahurangi and Wakamarama faults ceased motion before the Oligocene inundation of the area that resulted in deposition of the marine Ngatoro Group. The Paleocene-Eocene isopach map of Thrasher and Cahill (1990) (Figure 4.12) shows the Kahurangi Fault to have at most $500 \mathrm{~m}$ of throw during the Paleocene through Eocene interval, while the Wakamarama Fault experienced only about $200 \mathrm{~m}$ of throw. Given the great thickness of rapidly deposited late Cretaceous sediments adjacent to both major faults (in excess of $2000 \mathrm{~m}$ ) it is quite likely that most or all of the Paleocene throw on these faults is due to differential compaction of the underlying Cretaceous sediments. Tectonic throw may have been minimal.

The folding of the strata into the anticlines that dominate the present structure of the region is a post-Oligocene event. This folding resulted from reverse motion on the faults which controlled the original extension in the region. The truncation of sediments at the base Pliocene unconformity (see Figure 4.13), and the presence of mid Miocene sediments below the unconformity in the wells Cook-1 and Fresne-1, indicates that most of the folding occured during the late Miocene. The deformation of the Base Pliocene unconformity over these structures indicates that some reverse motion has continued into the Pliocene to Recent period.

Deformation of the base Pliocene unconformity along the Kahurangi Fault north of the Cook-1 well indicates that the reverse motion on that fault is propagating in a northerly direction. The greater uplift of the Wakamarama anticline to the south, and the northward plunge of that anticline north of the Fresne- 1 well indicates that Wakamarama Fault reverse motion may also have propagated northward. 


\subsection{Sedimentation in the Pakawau Basin}

Motion on the Wakamarama Fault, and other faults controlling the rift geometry of the Pakawau Basin, maintained a sedimentary depocentre throughout at least much of the Haumurian, although the time of initiation of tectonism and consequent sedimentation is uncertain. The first sediments deposited in the Pakawau Basin were probably the coarse clastics of the Otimataura Conglomerate Member of the Rakopi Formation. In Cape Farewell-1 this conglomerate is very hard, and grain supported (Carter and Kintaner 1987). Bishop (1971) described the Otimataura Conglomerate as a massive, coarse, indurated rock containing well rounded basement cobbles in a sandy matrix. He states that the conglomerate appears to rest on a leached basement surface, although in the north of the outcrop area it may be underlain by up to $100 \mathrm{~m}$ of coal measures. Little is known about the distribution of the Otimataura Conglomerate, or its sedimentology, although Bishop considers it non-marine. The unit is probably thickest proximal to the fault scarps which induced basement relief, thus uplifting sediment sources and forming local depocentres.

The coal measures of the Rakopi Formation interfinger with the Otimataura Conglomerate. Boreholes UC-1 and UC-3 have Rakopi Formation resting directly on basement, as it also does along the Patarau River near the confluence with Thompson Creek. The uniformity of the Rakopi Formation indicates that sedimentation and subsidence must have been in near balance for the duration of deposition. Paleocurrent or sediment transport-direction indicators have not been recorded from this formation. Paleontological examination of samples from the outcrop area indicates a non-marine environment of deposition (Raine, written communication, see Appendix 2), although Carter and Kintaner (1987) use evidence of glauconite, and a single dinoflagellate specimen in the Cape Farewell-1 well, to invoke a distant marine influence. These observations have not been independently confirmed, and may be due to cavings. 
The cyclic, interbedded sand/shale/coal sequence and the thin-bedded nature of the Rakopi Formation indicate a combination of meandering stream, floodplain and swamp environments. Leeder and Gawthorpe (1987) describe such a depositional setting as a "continental half-graben with axial through drainage."

Lateral continuity of beds within the Rakopi Formation cannot be demonstrated from the limited outcrop exposure. Subsurface stratigraphic control, from wells and boreholes, is not of sufficient density to ascertain the lateral extent of individual beds or sets of beds. Seismic reflection character does not demonstrate much lateral continuity of reflectors, so extensive lateral continuity of bedding seems unlikely. A meandering-stream depositional setting is likely to produce considerable lateral and vertical variation in sedimentary environments and preservation.

The geophysical mapping presented in Chapter 5 indicates that most of the Rakopi Formation was deposited when the Pakawau Basin was an enclosed depocentre, some distance from the sea. Figure 4.15 is a portion of the Rakopi Formation isopach map. This mapped interval includes the Otimataura Conglomerate Member, but the undifferentiated Rakopi Formation makes up the majority of the unit. The Pakawau Basin was probably swampy throughout this period, and likely had through-going drainage northward to similar basins along the Taranaki Rift trend. This proposed environment, at a time near the end of Rakopi Formation deposition, is schematically portrayed in Figure 4.16.

The en-echelon terrestrial sub-basins, in which Rakopi Formation sediments were being deposited, flooded from the north during the late Cretaceous marine transgression. By latest Cretaceous time this transgression resulted in the rift being at least partly submerged as a shallow-marine embayment. It is in this restricted marine, tidally-influenced setting that the North Cape Formation was deposited. Figure 4.17 is a portion of the upper late-Cretaceous isopach map, 


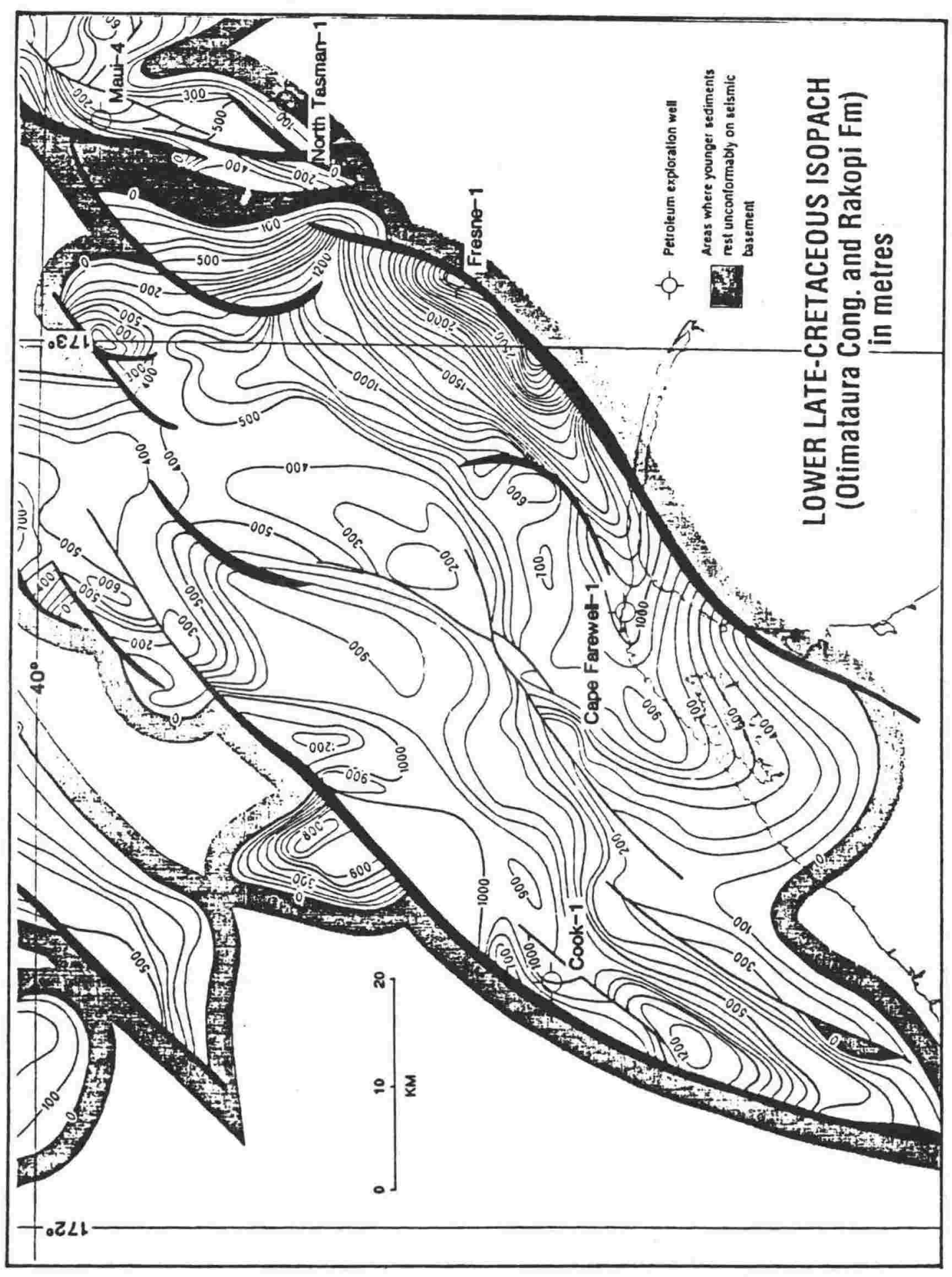

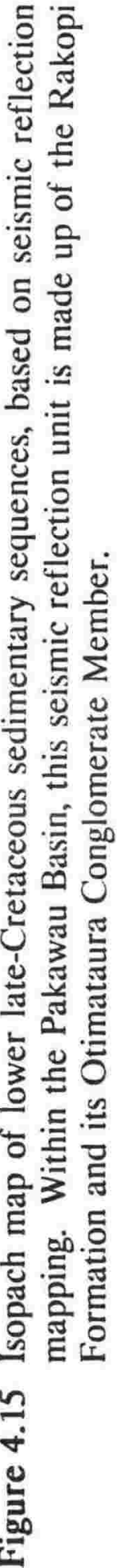




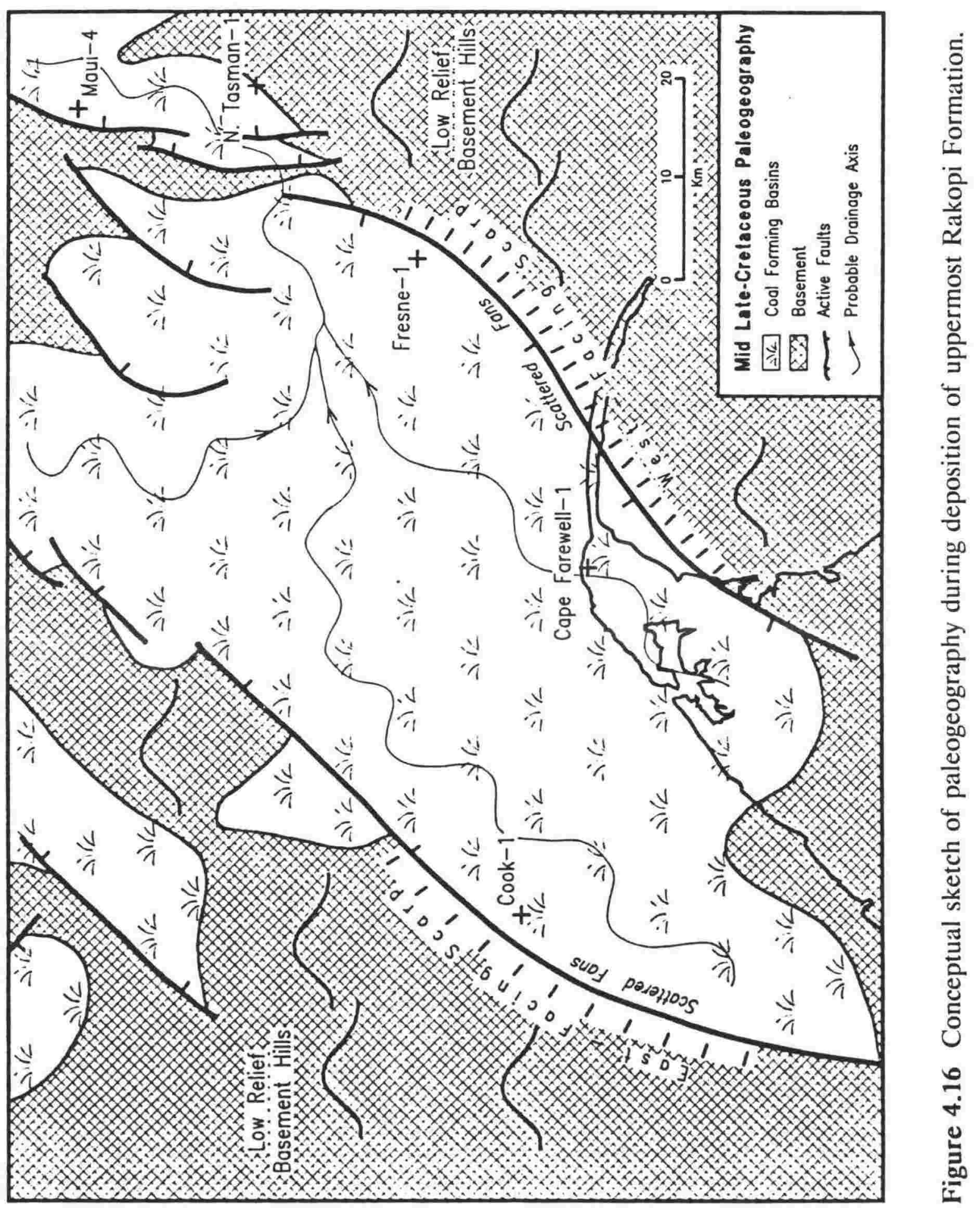




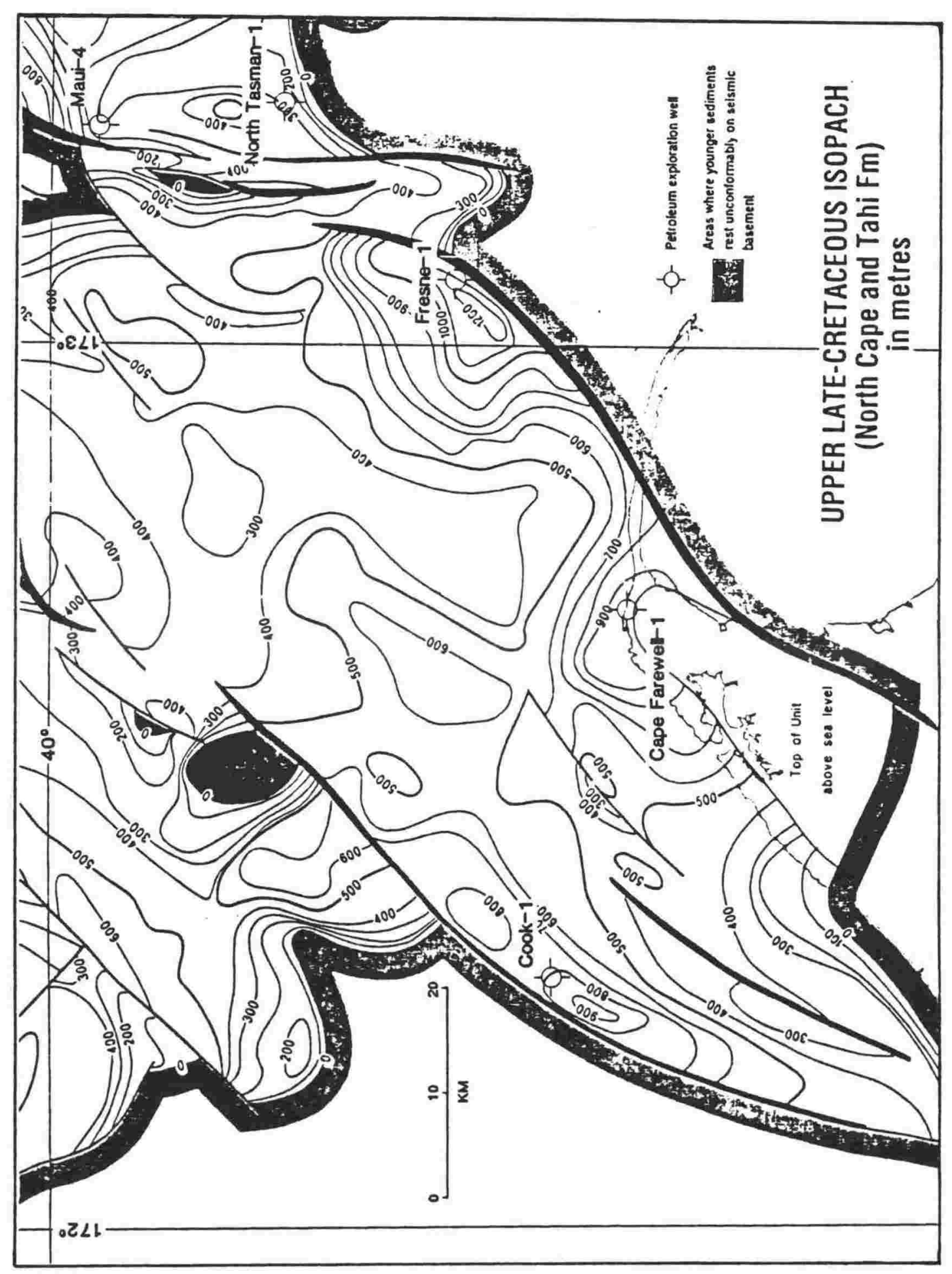

등 늘

एँ

光

$\frac{2}{2}$

등 ్ㅡㅁ

ㄹ

$\approx \cong$

คิ

炗 을

룽

एँ

突毕

는

E ¿

记瓷

อ

ठู ส

ฮี

记芯

ญ ส

苛光

$\leftarrow$ 늘

읔를

능 들 을

응 宊

들 은

응 है을

可 
which shows the thickness of the transgressive sediments of the North Cape Formation.

Previous investigators have all considered the North Cape Formation to have been deposited in a fluvial setting (for example, Suggate 1956, Bishop 1971, Titheridge 1977, and Carter and Kintaner 1987). Well completion reports for both Cook-1 (New Zealand Aquitaine Petroleum Ltd 1970) and Fresne-1 (New Zealand Aquitaine Petroleum 1976) also interpret the subsurface continuation of the North Cape Formation to be of fluvial origin. Recent biostratigraphic data, seismic interpretation, and field observations combine to refute the non-marine interpretation. Indeed, much of the North Cape Formation is probably of marine origin. The evidence used to reach this conclusion is as follows:

1. Observations of outcropping sequences of the North Cape Formation in Northwest Nelson include many sedimentary features inconsistent with a non-marine environment of deposition. These features include small-scale ripple-bedding, bi-modal ripples, mud drapes over fine-scale current indicators, rare burrows, and thick, uniformly-bedded, fine sandy units. Figure 4.4 illustrates a few of these features.

2. Samples from these outcrops have yielded dinoflagellate cysts and other marine algae (Wilson 1991a, see Appendix 2).

3. Redating of the Fresne-1 well sequence (Hayward and Raine 1985) and Cook-1 (Wilson 1991b, see Appendix 2) has revealed the presence of dinoflagellate cysts in North Cape Formation sequences in both wells. The Cook-1 well is particularly significant as the entire North Cape sequence in the well, over $800 \mathrm{~m}$ thick, may have been deposited in a nearshore marine environment. 
4. Seismic reflection mapping, tied to wells which have a demonstrable marine influence in the Late Cretaceous (for example Kiwa-1, Maui-4, and North Tasman-1), indicates a continuous upper late-Cretaceous sequence of similar seismic reflection character throughout the rift sub-basins of southern Taranaki, including the Pakawau Basin. These observations will be discussed in detail in Chapter 7.

In outcrop, the North Cape Formation demonstrates a north-to-south fining trend of the sediments. Sandy conglomerates north of Whanganui Inlet grade to fine sandstones in southern reaches of the inlet. Paleocurrent indicators recorded by both Titheridge (1977) and Bussell (1985) indicate sediment transport away from the fault scarp of the Wakamarama Fault, and not necessarily down the northward plunge of the basin. The sedimentology of the North Cape Formation has been covered in more detail by Wizevich and Thrasher (1991) and Wizevich and others (in press).

A model for North Cape sedimentation which can explain all of the present observations of the unit incorporates fan-delta deposition off an active Wakamarama Fault scarp into a shallow marine or estuary environment. Seismic isopach and facies mapping indicates the likelihood of two fan-delta complexes along the eastern margin of the Pakawau Basin, as illustrated in Figure 4.18. One apex would have been near the present community of Puponga, while the other would have been near the Fresne-1 well site. Their locations may have been controlled by minor en-echelon offsets in the trace of the Wakamarama Fault.

The heads of these fan deltas were probably maintained above sea level, while their toes prograded into the sea or estuary. Grain size should diminish progressively away from the delta apex. Locally, coal forming environments, such as that responsible for the deposition of the Puponga Member, may have formed within the fan-delta complex. Numerous examples of such fan deltas have been documented in Nemec and Steel (1988). 


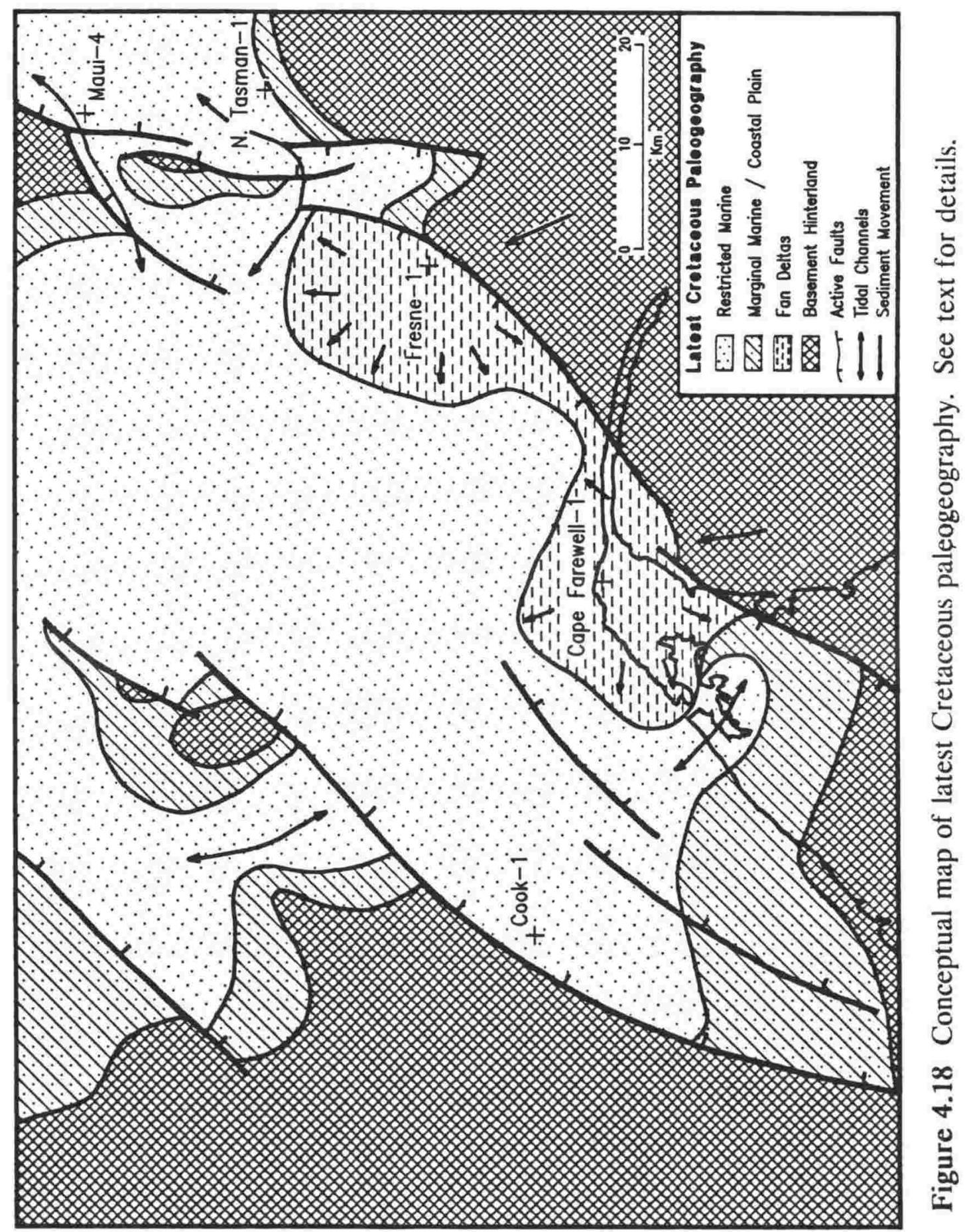


Elsewhere around the shores of the restricted marine embayments, beaches and coastal plain environments would have formed. These settings probably had localized coal-forming areas as well. The rare coal beds observed in the North Cape Formation south of Whanganui Inlet (for example in the core holes illustrated on Enclosure 4.1) and coal beds in the lower $200 \mathrm{~m}$ of the North Tasman-1 exploration well may have been deposited in such environments. Within the marine to marginal marine setting, tidal channel and sandbar development may have been common.

At about the time of the Cretaceous/Tertiary boundary a major regression in the Pakawau Basin caused the region to revert to non-marine sedimentation. This regression is represented by the Farewell Formation. The outcrop evidence for this is the massive, terrestrial sands and conglomerates of the Farewell Formation, which outcrop as spectacular cliffs around the western side of Whanganui Inlet, and the widespread existence of Paleocene-age coal measures overlying late-Cretaceous marine rocks in offshore exploration wells (for example, North Tasman-1, Fresne-1, Kiwa-1, and Maui-4). This regression is also observable on seismic reflection profiles as a change in seismic reflection character. The geologic reason for the regression is not understood, but increased sediment supply seems to have resulted in a rapid outbuilding of the coastal plain across the entire southern Taranaki region.

\subsection{Petroleum source potential of the Pakawau Basin}

There are three widespread pre-Oligocene formations in the Pakawau Basin: the Rakopi, North Cape and Farewell formations. Several geochemical studies of Taranaki Basin have included analysis of samples from the exploration wells Cook-1 and Fresne-1 which have penetrated these formations. The most significant of these studies have been conducted by Analabs (1984), Robertson Research (1984) and Cook (1987). All three of these reports rated the source potential of the North Cape and Farewell formations as poor. These formations 
are almost devoid of organic matter, being massive sands and conglomerates. These studies also show both formations to be immature for petroleum generation where sampled.

The only pre-Oligocene formation in Pakawau Basin which can be considered as having significant potential to source petroleum is the Rakopi Formation. Analabs (1984), Robertson Research (1984) and Cook (1987) all consider Rakopi Formation sequences to be a good potential source rock. Three exploration wells have penetrated portions of this formation in the basin: Cook-1, Fresne-1 and Cape Farewell-1. The Fresne-1 well only penetrates the uppermost $50 \mathrm{~m}$ of the formation, but data from Cook-1 (which penetrates over $400 \mathrm{~m}$ of Rakopi Formation) and Cape Farewell-1 (over $1500 \mathrm{~m}$ of Rakopi Formation) allow for assesment of source potential and maturity.

The Rakopi Formation in Cape Farewell-1 includes several intervals of fine-grained, organic rich sediments. With funding from Albion International Resources, Inc., well cuttings held by DSIR Geology and Geophysics were sent to Geotechnical Services Pty Ltd, of Western Australia, for Total Organic Carbon (TOC) determination and Rock-Eval Pyrolysis. The results of these analyses are reported in Table 4.1.

Six of the seven intervals sampled in Cape Farewell-1 were from fine grained (shale) sequences, one sample (at $1550 \mathrm{~m}$ ) was from a coal-bearing sequence. No sandstone intervals were sampled. Shale TOC values range from $2 \%$ to $10 \%$, while the coal-bearing sample had a TOC of $23 \%$. TOC values in clean coal are generally in excess of $50 \%$, and may be up to $90 \%$. Other Rock-Eval indicators, such as $\mathrm{S} 1$ and $\mathrm{S} 1+\mathrm{S} 2$, indicate very good source rock potential for these facies of the Rakopi Formation.

Figure 4.19 is a plot of S2 (hydrocarbon generating potential) versus TOC. There is a linear relationship between these two parameters, suggesting all 7 samples contain similar organic material. On Figure 4.20 these seven samples 
TABLE 4.1: Rock-Eval pyrolysis data, Cape Farewell-1.

WELLNAME $=$ Cape Farewell-1

DATE OF JOB = June 1991

$\begin{array}{lccccccccccc}\text { DEPTH(a) } & \text { TMAX } & \text { S1 } & \text { S2 } & \text { S3 } & \text { S1+S2 } & \text { S2/S3 } & \text { P1 } & \text { PC } & \text { TOC } & \text { HI } & \text { OI } \\ 1250.0 & 425 & 1.61 & 32.54 & 0.88 & 34.15 & 36.98 & 0.05 & 2.83 & 8.70 & 374 & 10 \\ 1380.0 & 429 & 1.50 & 30.50 & 1.00 & 32.00 & 30.50 & 0.05 & 2.66 & 9.60 & 318 & 10 \\ 1550.0 & 434 & 3.60 & 71.85 & 2.26 & 75.45 & 31.79 & 0.05 & 6.26 & 23.00 & 312 & 10 \\ 1800.0 & 433 & 0.96 & 17.31 & 0.64 & 18.27 & 27.05 & 0.05 & 1.52 & 5.46 & 317 & 12 \\ 1920.0 & 433 & 0.42 & 5.28 & 0.19 & 5.70 & 27.79 & 0.07 & 0.47 & 1.73 & 305 & 11 \\ 2030.0 & 433 & 2.90 & 35.10 & 0.75 & 38.00 & 46.80 & 0.08 & 3.15 & 9.69 & 362 & 8 \\ 2150.0 & 432 & 0.78 & 10.07 & 0.25 & 10.85 & 40.28 & 0.07 & 0.90 & 2.83 & 356 & 9\end{array}$

$\begin{array}{llll}\text { TMAX } & =\text { Max. temperature S2 } & \text { S1 } & =\text { Volatile hydrocarbons (HC) } \\ \text { S2 } & =\text { HC generating potential } & \text { S1+S2 } & =\text { Potential yield } \\ \text { S3 } & =\text { Organic carbon dioxide } & \text { PI } & =\text { Production index } \\ \text { PC } & =\text { Pyrolysable carbon } & \text { TOC } & =\text { Total organic carbon } \\ \text { HI } & =\text { Hydrogen index } & \text { OI } & =\text { Oxygen Index }\end{array}$

Note: Limiting conditions for source rock richness (Cook 1988):

$\begin{array}{llll}\begin{array}{l}\text { Source } \\ \text { Quality }\end{array} & \begin{array}{c}\text { TOC } \\ \%\end{array} & \begin{array}{l}\mathrm{S1} \\ \mathrm{mg} / \mathrm{g}\end{array} & \begin{array}{l}\mathrm{S1+S2} \\ \mathbf{\mathrm { mg }} / \mathrm{g}\end{array} \\ \text { Excellent } & >4 & >1.6 & >20 \\ \text { Very good } & 2-4 & 0.8-1.6 & 10-20 \\ \text { Good } & 1-2 & 0.4-0.8 & 6-10 \\ \text { Fair } & 0.5-1 & 0.2-0.4 & 1-6 \\ \text { Poor } & <0.5 & <0.2 & <1\end{array}$




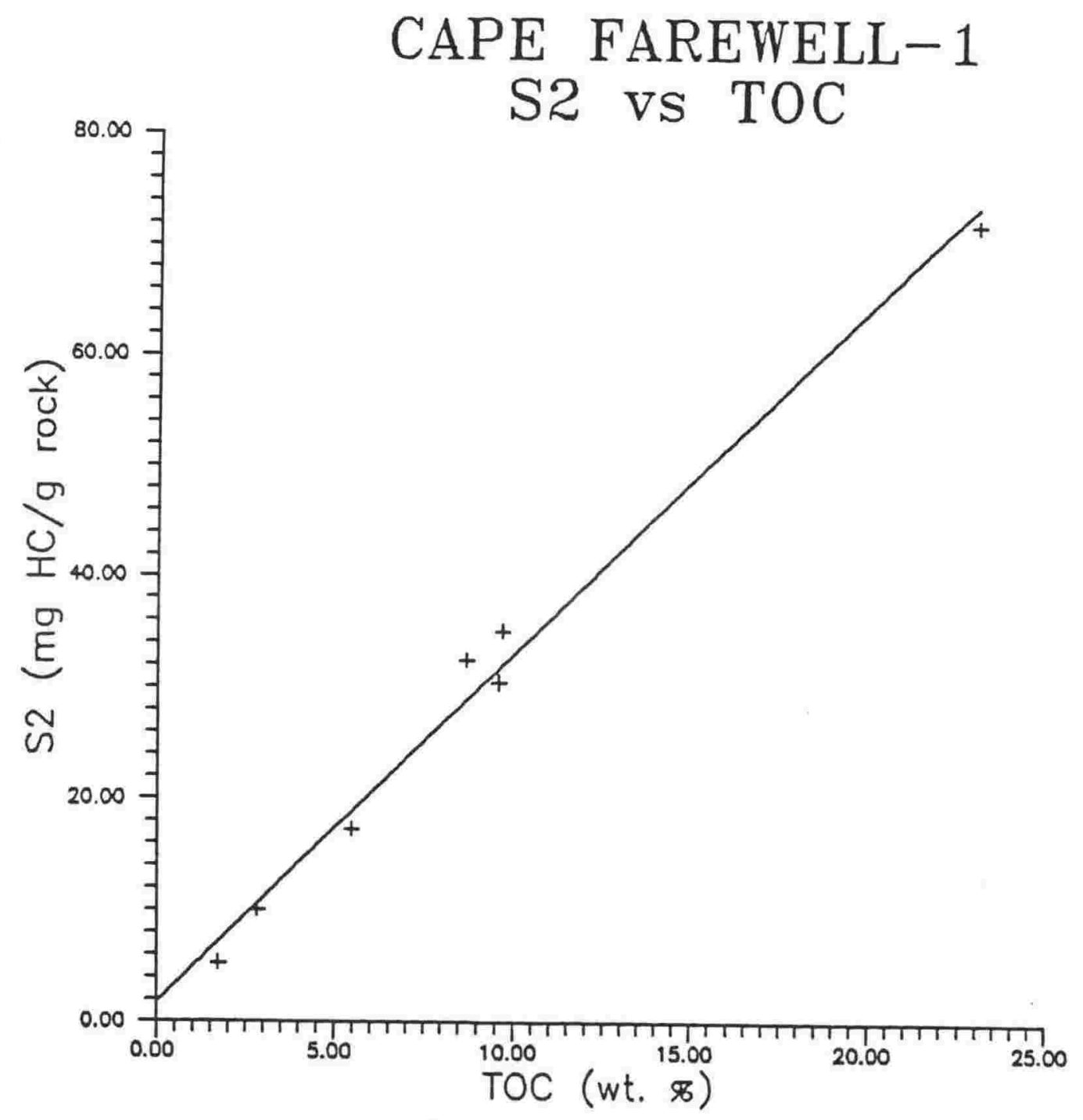

Figure 4.19 Rock-Eval S2 versus Total Organic Carbon (TOC) for seven samples from Cape Farewell-1. See Table 1 for data. 


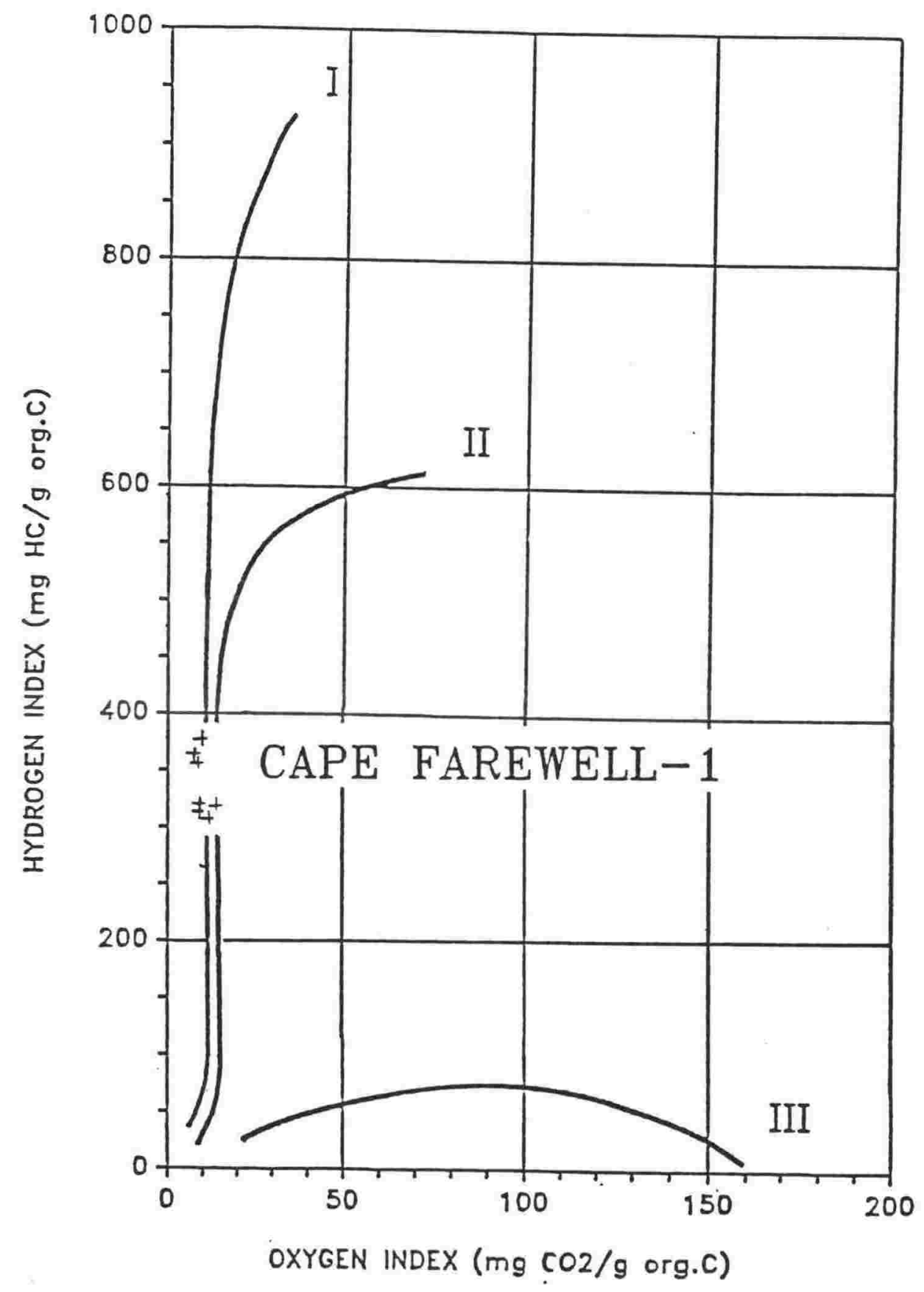

Figure 4.20 Hydrogen Index versus Oxygen Index for Cape Farewell-1 samples, from Rock Eval Pyrolysis. Kerogen type I, II and III curves after Geotech (1991). See Table 1 for data. 
are plotted on a Hydrogen Index versus Oxygen Index graph (after Geotech, 1991). This graph also shows the average relationships, determined by Geotech (1991) for types I, II and III kerogen. The average curve for type III, determined by Espitalie and others (1985), is slightly higher, and has a peak near the Y-axis. All seven Cape Farewell-1 samples plot very close together, near the vertical portion of the types I and II curves. Peters (1986) indicates that samples plotting in this position are from oil-prone source rocks.

Murchison (1987) discusses kerogen types for petroleum source rocks. Type I kerogen is generally from algal-dominated, fresh-water environments. Type II kerogen is from marine organisms. Type III kerogen is the product of terrestrial plants. Given the non-marine depositional setting of the Rakopi Formation, type II kerogen can be ruled out as the source of the organic matter in the Cape Farewell-1 samples.

The visual identification of plant debris in Rakopi Formation field and outcrop samples makes the lack of type III kerogen geochemical indicators confusing. Additional geochemical research may be able to identify the organic material responsible for this apparent discrepancy, and for the high-quality source beds within the Rakopi Formation.

The intervals in the Cape Farewell-1 well upon which geochemical testing was conducted were specifically selected because of their fine-grained nature. The applicability of the results to the formation as a whole requires consideration of the lithologic content. The lithological log of Cape Farewell-1 has been reviewed to determine the relative abundance of various lithologies over the Rakopi Formation interval. The record of cutting returns was separated into three lithological categories: sand, shale and coal. Over the $1550 \mathrm{~m}$ thickness of the Rakopi Formation in Cape Farewell-1, the composition of the formation was $6 \%$ coal, $32 \%$ shale, and $62 \%$ sand. 
Two other wells, Cook-1 and the Rakopi Bore, have penetrated over $400 \mathrm{~m}$ of Rakopi Formation rocks. To ascertain if the abundances found in Cape Farewell-1 were representative of the formation elsewhere, the lithology logs of these two wells were also used to determine relative abundances of lithologies. The results of these determinations are compared in Table 4.2. Cook-1 is about $35 \mathrm{~km}$ west-north-west of Cape Farewell-1, and the Rakopi Bore is about $17 \mathrm{~km}$ southwest of Cape Farewell-1. Even at these widely spaced points the relatively abundances of sand, shale and coal are similar. The average of the abundances in the three wells are $4 \%$ coal, $33 \%$ shale, and $63 \%$ sand; almost identical to the Cape Farewell-1 values.

TABLE 4.2: Rakopi Formation relative lithologic abundance

Well

$$
\begin{aligned}
& \text { Rakopi Fm } \\
& \text { Thickness }
\end{aligned}
$$

$\%$ Sand

\% Shale

\% Coal

Cape Farewell-1

$1550 \mathrm{~m}$

62

32

6

Cook-1

$430 \mathrm{~m}$

58

38

4

Rakopi Bore

$410 \mathrm{~m}$

$\underline{69}$

$\underline{28}$

$\underline{3}$

Average

63

33

4

With the Rakopi Formation comprising about $33 \%$ shale, about $1 / 3$ of the total formation thickness may be composed of potential source rocks of very good to excellent richness. An additional $6 \%$ of the volume of the formation may be composed of coal. Because the formation is laterally extensive in the basin, and commonly very thick (500 to $3000 \mathrm{~m}$ ), it represents a viable source rock where mature. 
Estimation of the total volume of these source rocks within the oil generating window during various time periods, the generating ability of that volume, and the migration efficiency of the enclosing rocks, can help assess the risk factors to be applied to source and fill estimates for the prospects within the Pakawau Basin. Important methods for such investigations have recently been detailed by Mackenzie and Quigley (1988) and Forbes and others (1991).

Vitrinite reflectance (Ro) data for Cape Farewell-1 were included in the well completion report (Carter and Kintaner 1987). These data are displayed in Figure 4.21, plotted against uncorrected depth. For New Zealand coal-bearing rocks R.P. Suggate (pers. com.) has calculated Ro values of about $0.5 \%$ for the onset of oil generation and about $0.7 \%$ for the onset of expulsion (migration). These Ro values correspond approximately to "Suggate Rank" values of Rank(S) 9-10 for start of oil generation and Rank(S) 13-14 for onset of expulsion calculated for Taranaki Basin by Sykes and others (in press). Using these criteria, the Rakopi Formation sequence penetrated by Cape Farewell- 1 entered the oil generation window, but may not have expelled oil for migration prior to anticlinal uplift.

Rock-Eval pyrolysis data from Cape Farewell-1 also indicate that the Rakopi Formation is mature for oil generation. Figure 4.22 is a plot of $T_{\max }$ versus uncorrected depth. Most of the values are in excess of 430, the onset of oil generation according to Espitalie and others (1985).

Numerous weak oil and gas shows were reported during the drilling of the Rakopi Formation in Cape Farewell-1, although the well was not drilled on a structural closure. These shows indicate that petroleum has been generated within the Pakawau Basin. In addition, sample descriptions made during vitrinite reflectance study of cuttings from the well make common reference to oil drops present within cutting chips. 


\section{Vitrinite Reflectance}

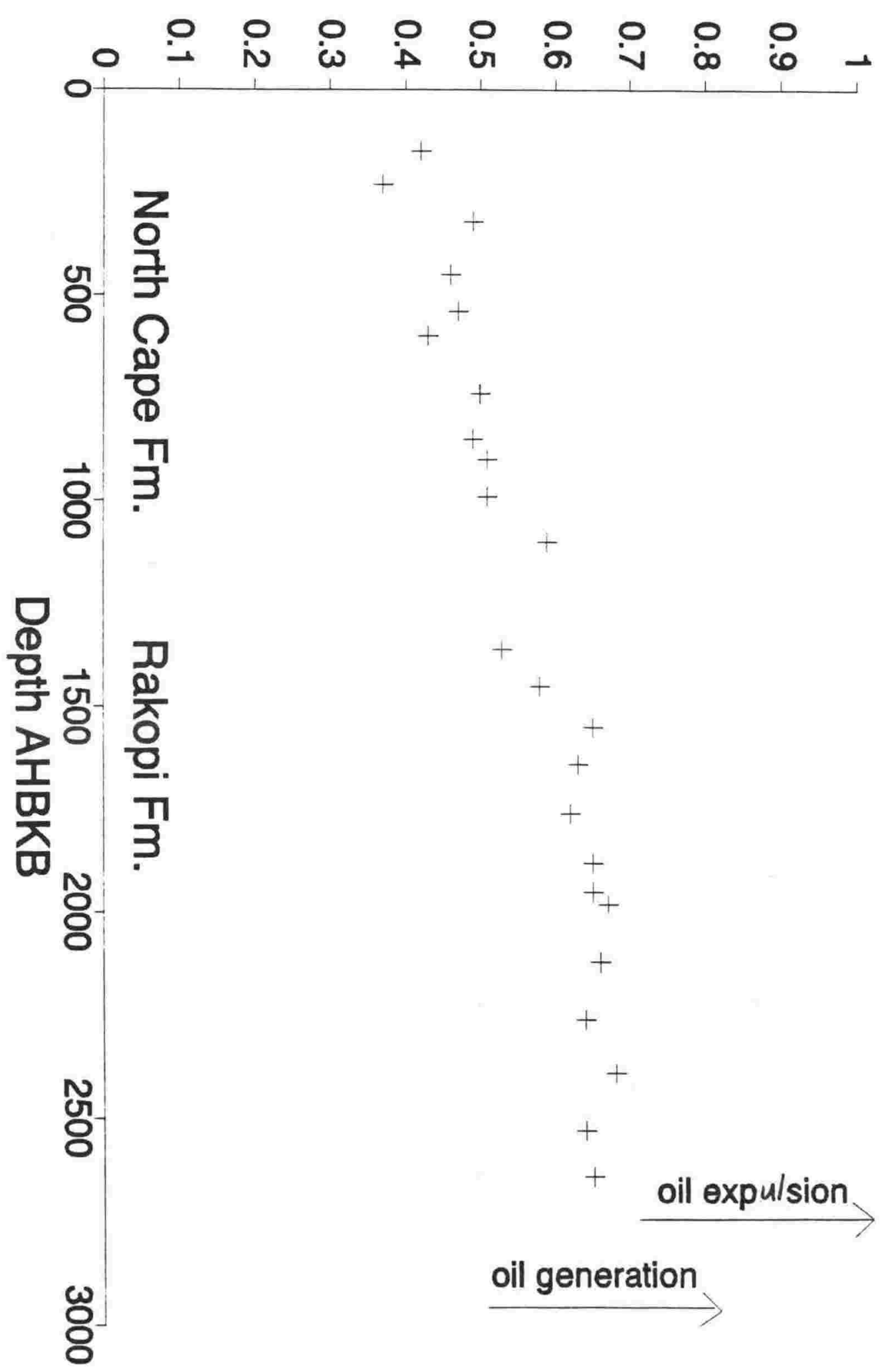

Figure 4.21 Vitrinite reflectance measurements from Cape Farewell-1 (reported in Carter and Kintaner 1987). 
Elsewhere in the basin, maturity may be even greater. From the plots of vitrinite reflectance and $\mathrm{T}_{\max }$ (figures 4.21 and 4.22), the top of the Rakopi Formation interval in Cape Farewell- 1 displays Ro values in the $0.5-0.6 \%$ range, and $T_{\max }$ of about 425 . This compares well with Cook-1, where the data indicates $R_{o}$ also in the $0.5-0.6 \%$ range, and $T_{\max }$ values of about 430 . In Fresne-1, however, the top of the Rakopi Formation is more mature, with Ro values in the $0.65-0.8 \%$ range, and $\mathrm{T}_{\max }$ of up to 446 .

These indications of greater maturity at Fresne- 1 have two important consequences for the petroleum potential of the Pakawau Basin. First, it means that much of the basin, especially that underlying the Fresne structure, is probably mature not only for oil generation, but for expulsion and migration as well. The Rakopi Formation not penetrated by Fresne-1 probably has maturity far in excess of the Ro of $0.7 \%$ which Suggate (pers. com.) suggests is necessary for oil to be expelled.

The second consequence of the higher maturities recorded near the TD of Fresne-1 is structural. The sequence at Fresne-1 has undergone greater maturation due either to deeper burial or a higher geothermal gradient. Assuming a very similar geothermal gradient, then the area around the Fresne structure must have been deeper than other parts of the basin during maximum burial.

Overall, the Rakopi Formation is a viable source rock for oil. The formation has undergone sufficient maturation for generation and expulsion of petroleum in at least some parts of the basin, although insufficient maturity must still be considered a major risk for specific prospects. Maximum maturity was probably reached during maximum burial in the late Miocene when migration paths may have been substantially different from present subsurface gradients. 


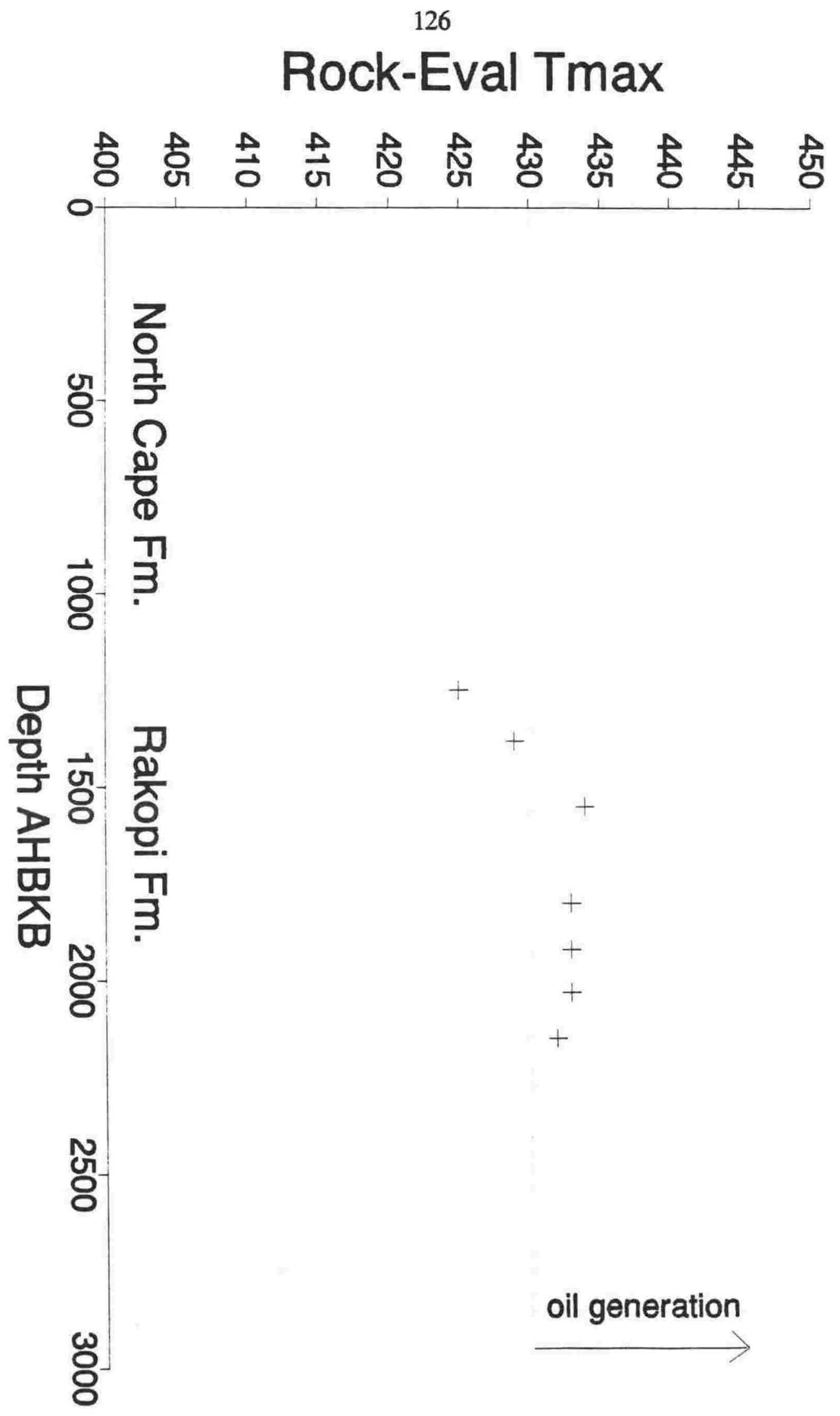

Figure 4.22 Rock Eval Tmax for Cape Farewell-1 samples. See Table 1 for data. 


\subsection{Reservoir potential of the Pakawau Basin}

Within the Pakawau Basin three formations have significant reservoir potential. These are the Paleocene Farewell Formation, and the Cretaceous North Cape and Rakopi formations. Within the region other stratigraphic sequences may have reservoir potential, notably the Oligocene carbonates and the Miocene channel and turbidite sandstones, but these are not considered within the scope of the present study.

The Rakopi Formation is the stratigraphically lowest unit in the basin. This formation is very thick, possibly reaching a maximum thickness of $3 \mathrm{~km}$ adjacent to the Wakamarama Fault in the vicinity of the Fresne-1 well location. The only direct measurement of reservoir properties from the Rakopi Formation in Pakawau Basin is from a core cut about $90 \mathrm{~m}$ below the top of the formation in Cook-1 (2338-2344 m). This six metre core is from an interbedded sand/shale sequence with minor coal. Eight porosity and permeability measurements are reported in the well completion report (New Zealand Aquitaine Petroleum Ltd 1970). Porosity ranges from $0.4 \%$ in carbonaceous siltstones to $14.3 \%$ in poorly-sorted coarse sandstone. Permeabilities range from $0.02 \mathrm{md}$ to $16.40 \mathrm{md}$. This represents a fair potential reservoir rock. Log porosities within the Rakopi Formation in Cook-1 (New Zealand Aquitaine Petroleum Ltd 1970) ranged from $18 \%$ near the top of the formation (2551 m) to $10 \%$ at TD.

Log porosities in the Fresne-1 well over the Rakopi Formation interval (2447 $\mathrm{m}$ to TD at $2504 \mathrm{~m}$ ) are mentioned in the well completion report (New Zealand Aquitaine Petroleum Ltd 1976) as being "in the range of 12-22\%". Fresne-1 penetrated only $50 \mathrm{~m}$ of the Rakopi Formation. This interval was predominantly sandstone, with several thin coal seams. A formation test (F.I.T.) was performed in this interval, and recovered 23 litres of saline formation 
water. Sissons and Walsh (1986) list porosities (presumably log-derived) from the Rakopi intervals in Cook-1 and Fresne- 1 of $20 \%$ and $17 \%$ respectively.

Log porosities calculated from the Cape Farewell-1 well (Carter and Kintaner 1987) range from $20 \%$ down to $2 \%$, with a downward decreasing trend. The upper $500 \mathrm{~m}$ of the Rakopi Formation averages about $10 \%$ porosity. Compaction due to burial is the probable cause of the downward decrease in porosity.

No porosity or permeability measurements have been conducted on the outcrop sequence or from coal exploration holes in the onshore part of the basin. The outcrop exposures tend to be deeply weathered, and are probably not suited to petrophysical evaluation without careful sampling of fresh rocks. The lack of preserved core from either coal or petroleum exploration wells renders further petrophysical evaluation of rocks penetrated by these wells difficult.

The Rakopi Formation intervals in Cook-1, Cape Farewell-1 and the Rakopi Bore are about $60 \%$ sandstones (Table 4.2), interbedded with siltstones, mudstones and coal. From the few petrophysical observations mentioned above, it appears sandstones within the Rakopi Formation would make acceptable, though not outstanding, reservoirs rocks. A large risk to their reservoir potential is the possible lack of internal seals. The fine grained intervals within the Rakopi Formation may act as internal seals sufficient to trap hydrocarbons in favourable structural or stratigraphic situations. These fine grained intervals are, however, thin and probably laterally discontinuous. The sands within the formation may be in communication, both laterally and vertically.

At present there are insufficient data, from either subsurface or outcrop studies, to properly assess the ability of the Rakopi Formation to provide both seal and reservoir units. 
The North Cape Formation overlies the Rakopi Formation throughout much of Pakawau Basin. These rocks are from several hundred to over a thousand metres thick within the basin depocentres. In the outcrop sequence and where drilled in wells Cook-1, Fresne-1 and Cape Farewell-1 they are predominantely massive sandstones, with interbedded conglomerates. In the Fresne-1 well the North Cape Formation has wireline log porosities in excess of $20 \%$ (New Zealand Aquitaine Petroleum Ltd 1976). Similarily high values were obtained from the Cook-1 wireline logs (New Zealand Aquitaine Petroleum Ltd 1970). The Cape Farewell-1 well (Carter and Kintaner 1987) exhibited slightly lower log porosities, in the range of $10-20 \%$. No record of permeability measurements from this formation has been found.

The North Cape Formation sandstones within the Pakawau Basin would probably make an acceptable reservoir rock. The possible lack of internal seals within the formation, however, means that its entire thickness is probably in horizontal and vertical communication. If the fan-delta model presented in Figure 4.18 is correct, then lateral facies changes away from the crest of the fans may lead to stratigraphic trapping under very favourable conditions.

Finer grained coal measures exist near the top of the North Cape Formation, including the Puponga Member onshore and the coals at the top of the Cretaceous sequence in the Fresne- 1 well. These coal measures are thin, probably laterally discontinuous, and contain significant sand units. This sequence failed to trap significant petroleum in Fresne-1, at a level with considerable present-day structural closure. In places these coal measures may have sufficient integrity to act as a top seal for the North Cape Formation, but prediction of this would require more systematic data.

Where it outcrops, the Paleocene Farewell Formation, which overlies the North Cape Formation, consists of sands and massive conglomerates several hundred metres thick. This coarse, lithic nature is also observed in the subsurface in exploration wells. Estimated porosities in the Farewell Formation from wireline 
logs indicate fair reservoir potential. In the Cook- 1 well a porosity of $20 \%$ is recorded from these rocks (Sissons and Walsh 1986). Porosities of 17-28\% are recorded in the Fresne-1 well (New Zealand Aquitaine Petroleum Ltd 1976).

Like the North Cape Formation, the Farewell Formation has a complete lack of internal seals, and probably has total internal communication. The Farewell Formation is capped by the carbonate-rich sediments of the Oligocene Ngatoro Group, which should provide a fairly good top-seal, although neither the Cook-1 or Fresne-1 wells had petroleum accumulations trapped under the Ngatoro Group strata despite apparent present-day structural closure at that level.

In summary, the Pakawau Basin has almost continuous reservoir potential throughout the $4000 \mathrm{~m}$ thick late Cretaceous and Paleocene sequence. Because the sequence is uplifted $2-3 \mathrm{~km}$ above its maximum burial, loss of porosity and permeability due to compaction and alteration is probably a significant problem in the deeper portions of the Rakopi Formation. Estimating the depth limit of acceptable reservoir porosity is difficult, but Cape Farewell-1 data indicate that the upper $500 \mathrm{~m}$ of the Rakopi Formation contains porosities of $10 \%$.

The main limitation to petroleum charging of reservoirs in the Pakawau Basin is the limited development of top seal. The only two potential seals are the Oligocene and younger rocks which may act as top seal over the entire late Cretaceous and Paleocene sequence, and the finer sequences of potential internal seals within the North Cape and Rakopi formations. Prediction of these internal seals will be difficult, and their sealing efficiency is questionable.

\subsection{References}

Analabs 1984: Petroleum geochemistry of the Taranaki Basin. Unpublished open-file petroleum report 1013, filed at DSIR Geology and Geophysics, Lower Hutt. 
Bell, J.M.; Webb, E.J.H.; Clarke, E. de C. 1907: The geology of the Parapara subdivision, Karamea, Nelson. New Zealand Geological Survey bulletin n.s. 3.

BHP Exploration Dept. 1985a: Utah Exploration Incorporated coal prospecting licences 35215 and 35256, New Zealand, phase 1 exploration results. Unpublished company report 4445, Mines Department, Wellington.

BHP Exploration Dept. 1985b: Utah Exploration Incorporated coal prospecting licences 35215 and 35256, New Zealand, particulars of boring operations undertaken during April/May, 1985. Unpublished company report 4587, Mines Department, Wellington.

BHP Exploration Dept. 1985c: Utah Exploration Incorporated coal prospecting licences 35215 and 35256, New Zealand, results of drilling programme undertaken during April/May, 1985. Unpublished company report 4588, Mines Department, Wellington.

Bishop, D.G. 1968: Sheet S2 - Kahurangi. Geological map of New Zealand 1:63,360. Wellington, New Zealand. Department of Scientific and Industrial Research.

Bishop, D.G. 1971: Sheet S1 and S3 - Farewell and Collingwood. Geological map of New Zealand 1:63,360. Wellington, New Zealand. Department of Scientific and Industrial Research.

Bruhn, R.L.; Gibler, P.R.; Parry, W.T. 1987: Rupture characteristics of normal faults: an example from the Wasatch fault zone, Utah. In: Coward, M.P.; Dewey, J.F.; Hancock, P.L. (eds), 1987, Continental Extension Tectonics, Geological Society Special Publication No. 28: 337-353. 
Bussell, M.R. 1985: Report following geological mapping of the Pakawau Group in Whanganui (Westhaven) Inlet, northwest Nelson. Unpublished report, Mines Department, Wellington.

Carter, M.; Kintaner, E.R.L. 1987: Cape Farewell-1, well completion report PPL 38119. Unpublished open-file petroleum report 1234, filed at DSIR Geology and Geophysics, Lower Hutt.

Collen, J.D. 1987: Report for coal prospecting licences 35-247 and 35-257. Unpublished report, Mines Department, Wellington.

Collen, J.D. 1988: Diagenetic control of porosity and permeability in Pakawau and Kapuni group sandstones, Taranaki Basin, New Zealand. Energy Exploration and Exploitation 6(3): 263-280.

Cook, R.A. 1987: The geology and geochemistry of the crude oils and source rocks of western New Zealand, Ph.D. thesis, Victoria University of Wellington.

Espitalie, J.; Deroo, G.; Marquis, F. 1985: La pyrolyse Rock-Eval et ses applications, deuxieme partie. Revue de l'Institut Francais du Petrole 40: 755-784.

Forbes, P.L.; Ungerer, P.M.; Kuhfuss, A.B.; Riis, F.; Eggen, S. 1991: Compositional modeling of petroleum generation and expulsion: trial application to a local mass balance in the Smorbukk Sor Field, Haltenbanken area, Norway. American association of petroleum geologists bulletin, v. 75: 873-893.

Geotech 1991: Petroleum geochemistry for exploration geoscientists; unpublished course notes. 
Grindley, G.W. 1961: Sheet 13 - Golden Bay. Geological map of New Zealand 1:250,000. Wellington, New Zealand. Department of Scientific and Industrial Research.

Harrison, D.; Van Oyen, F. 1969: Geological reconnaissance of the Tasman Bay and Golden Bay areas: Geological note 100. Unpublished open-file petroleum report 510, filed at DSIR Geology and Geophysics, Lower Hutt.

Hancock and Associates 1987: Resource potential of coal prospecting licences 35-215 and 35-256, northwest Nelson. Unpublished report, Mines Department, Wellington.

Hayward, B.W.; Raine, J.I. 1985: Biostratigraphy of Fresne-1 offshore well, near Cape Farewell. New Zealand Geological Survey report Pal-101.

Jackson, J.A.; White, N.J. 1989: Normal faulting in the upper continental crust: observations from regions of active extension. Journal of Structural Geology 11(1/2): 15-36.

King, P.R. 1988: Well summary sheets, offshore Taranaki. New Zealand Geological Survey Report G127.

Knox, G.J. 1982: Taranaki Basin, structural style and tectonic setting. New Zealand Journal of Geology and Geophysics 25(2): 125-140.

Leeder, M.R.; Gawthorpe, R.L. 1987: Sedimentary models for extensional tiltblock/half-graben basins. In: Continental Extensional Tectonics, Geological Society Special Publication No. 28: 139-153.

Mackenzie, A.S.; Quigley, T.M. 1988: Principles of geochemical prospect appraisal. American association of petroleum geologists bulletin 72: 399-415. 
Mollah, R. 1976: Seismic interpretation Northwest-Nelson, Tasman PPL 38011 GP97. Unpublished open-file petroleum report 690, filed at DSIR Geology and Geophysics, Lower Hutt.

Murchison, D.G. 1987: Recent advances in organic petrology and organic geochemistry: an overview with some reference to 'oil from coal'. In: Coal and Coal-bearing Strata: Recent Advances, Geological Society Special Publication No. 32: 257-302.

Nathan, S.; Anderson, H.J.; Cook, R.A.; Herzer, R.H.; Hoskins, R.H.; Raine, J.I.; Smale, D. 1986: Cretaceous and Cenozoic sedimentary basins of the West Coast region, South Island, New Zealand. New Zealand Geological Survey basin studies 1.

Nemec, W.; Steel, R.J. (eds.) 1988: Fan deltas; sedimentology and tectonic settings. Blackie and Son Ltd, Glasgow, 444 pages.

New Zealand Aquitaine Petroleum Ltd. 1970: Cook-1 well completion report. Unpublished open-file petroleum report 513, filed at DSIR Geology and Geophysics, Lower Hutt.

New Zealand Aquitaine Petroleum Ltd. 1976: Well completion report - Fresne1. Unpublished open-file petroleum report 674, filed at DSIR Geology and Geophysics, Lower Hutt.

Ongley, M.; Macpherson, E.O. 1923: The geology and mineral resources of the Collingwood sudivision, Karamea Division. New Zealand Geological Survey bulletin n.s. 25 .

Palmer, J.A. 1985: Pre-Miocene lithostratigraphy of Taranaki Basin, New Zealand. New Zealand Journal of Geology and Geophysics, Vol.28: 197-216. 
Park, J. 1890a: On the geology and mineral resources of the west Whanganui coalfield, Collingwood County. New Zealand Geological Survey reports of geological explorations No.20 1888-1889: 49-60.

Park, J. 1890b: On the geology Collingwood County, Nelson. New Zealand Geological Survey reports of geological explorations No.20 1888-1889: 186-243.

Peters, K.E. 1986: Guidelines for evaluating petroleum source rocks using programmed pyrolysis. American association of petroleum geologists bulletin 70: 318-329.

Pilaar, W.F.H.; Wakefield, L.L. 1978: Structural and stratigraphic evolution of the Taranaki Basin, offshore North Island, New Zealand. The APEA Journal 10: 93-101.

Purcell, P.G. 1983: Final report Taranaki 1983 seismic survey, PPLs 38119, 38121, 38125 New Zealand. Unpublished open-file petroleum report 950, filed at DSIR Geology and Geophysics, Lower Hutt.

Purcell, P.G. 1984: Final report Farewell (1984) seismic survey PPL 38119. Unpublished open-file petroleum report 1064, filed at DSIR Geology and Geophysics, Lower Hutt.

Purcell, P.G. 1986: The coal basins of Western New Zealand--an introduction. In: Glenie, R.C. (ed.) Proceedings of the second south-eastern Australia oil exploration symposium. Petroleum Exploration Society of Australia: 319-330.

Raine, J.I. 1984: Outline of a palynological zonation of Cretaceous to Paleogene terrestrial sediments in the West Coast region, South Island, New Zealand. New Zealand Geological Survey report 109. 
Raine, J.I. 1989: Palynology of outcrop, upper Pakawau Group, northwest Nelson, New Zealand. New Zealand Geological Survey report Pal 148.

Roberts, S.; Jackson, J. 1991: Active normal faulting in central Greece: an overview. In: Roberts, A.M.; Yielding, G. and Freeman, B., 1991, The Geometry of Normal Faults, Geological Society Special Publication No 56: pp 125-142.

Robertson Research 1984: Petroleum geochemical evaluation of the Taranaki Basin, New Zealand. Unpublished open-file petroleum report 1022, filed at DSIR Geology and Geophysics, Lower Hutt.

Robinson, P. 1989: A depositional model for the Farewell Formation, Kupe South Field, South Taranaki Basin PPL 38116. Unpublished open-file petroleum report 1449, filed at DSIR Geology and Geophysics, Lower Hutt.

Shell Oil Company 1987: Seismic sequences as applied to basin-fill analysis: Taranaki Basin, New Zealand. In: Bally, A.W. (ed.) Atlas of seismic stratigraphy; American association of petroleum geologists, studies in geology 27: 53-71.

Sissons, B.A.; Walsh, R.D. 1986: Establishing the elusive paleo-play -- a case study of the Kahurangi Fault Zone, southern Taranaki, New Zealand. In: Second south-eastern Australia oil exploration symposium, Glenie, R.C. (ed), 1986, Petroleum Exploration Society of Australia: 331-336.

Suggate, R.P. 1950: Quartzose coal measures of west Nelson and north Westland. New Zealand journal of science and technology B31(4): 1-14.

Suggate, R.P. 1956: Puponga Coalfield. New Zealand journal of science and technology B37(5): 539-559. 
Suggate, R.P. 1959: New Zealand Coals. New Zealand Department of Scientific and Industrial Research bulletin 134.

Suggate, R.P. and Couper, R.A. 1952: The stratigraphic relations and plant microfossils of New Zealand coal measures. New Zealand journal of science and technology B34(2):106-117.

Sykes, R.; Suggate, R.P.; King, P.R. in press: Timing and depth of maturation in southern Taranaki Basin from reflectance and $\operatorname{rank}(\mathrm{S})$. In: Ministry of Commerce, 1991 New Zealand Oil Exploration Conference Proceedings.

Titheridge, D.G. 1977: Stratigraphy and sedimentology of the upper Pakawau and lower Westhaven groups (Upper Cretaceous- Oligocene), northwest Nelson. Unpublished M.Sc. thesis, University of Canterbury.

Thrasher, G.P. 1988: The interpretation of seismic reflection data from the Western Platform region of Taranaki Basin. Energy Exploration and Exploitation 6(2): 136-150.

Thrasher, G.P.; Cahill, J.P. 1990: Subsurface maps of the Taranaki Basin region, New Zealand. New Zealand Geological Survey report G-142 (copy in Appendix 1).

Wellman, H.W. 1940: The Ototaran peneplain of northwest Nelson. Unpublished M.Sc. thesis, Victoria University of Wellington.

Wellman, H.W. 1950: Geology of Sheets S1,2,3 (Farewell, Kahurangi, and Collingwood), with an outline of the geology of northwest Nelson and Westland. Unpublished manuscript held at the DSIR Geology and Geophysics library, Lower Hutt. 
Wells, P.E. 1984a: Cretaceous coals of northwest Nelson; A literature review. Unpublished report, Mines Department, Wellington.

Wells, P.E. 1984b: The Puponga coalfield. Unpublished report, Mines Department, Wellington.

Wilson, G.J. 1991a: Marine palynostratigraphy of New Zealand Aquitaine Petroleum Ltd. Cook-1 well, Southern Taranaki Basin, 4300'-8730'. Unpublished report GJW 217/91 on file with DSIR Geology and Geophysics, Lower Hutt (copy in Appendix 2).

Wilson, G.J. 1991b: Marine palynostratigraphy of the Pakawau Group, Northwest Nelson. Unpublished report GJW 218/91 on file with DSIR Geology and Geophysics, Lower Hutt (copy in Appendix 2).

Wizevich, M.; Thrasher, G. 1991: Sedimentation within the Pakawau Basin, Northwest Nelson. Abstract in: Geological Society of New Zealand Miscellaneous Publication 59A: 138.

Wizevich, M.C.; Thrasher, G.P.; Bussell, M.R.; Wilson, G.J.; Collen, J.D. in press: Marine deposition in the late Cretaceous Pakawau Group, Northwest Nelson. New Zealand Journal of Geology and Geophysics. 


\section{CHAPTER 5: SUBSURFACE GEOPHYSICAL MAPPING OF LATE CRETACEOUS SEQUENCES, TARANAKI BASIN.}

\subsection{Chapter abstract}

Seismic reflection data can be used to subdivide the late Cretaceous sedimentary sequence of Taranaki Basin into two major seismic-stratigraphic units. These two units are the lower late-Cretaceous rift-filling sediments deposited in isolated subbasins, and the upper late-Cretaceous regional transgressive sediments. The horizon which separates the two units essentially marks the end of sedimentation in confined subbasins and the beginning of Taranaki Basin as a single sedimentary basin.

The two seismic sequences can be mapped throughout most of Taranaki Basin using standard methods for the intrepretation of seismic reflection data. Petroleum exploration wells in the basin provide ties for the seismic reflection interpretation and also provide seismic velocity data for use in depth conversion of seismic travel times. The two units have well-log-derived average interval velocities of $4.4 \mathrm{~km} / \mathrm{sec}$ for the lower unit and $4.0 \mathrm{~km} / \mathrm{sec}$ for the upper unit. These velocities have been used in calculating unit thickness for the preparation of isopach maps of both units.

The mid late-Cretaceous seismic horizon is remarkably uniform throughout Taranaki Basin, and does not represent a major unconformity. It is in places a mild unconformity, indicating the local loss of some section from the lower unit. It is also in places the base of a trangressive sequence. The horizon is expected to be regionally time transgressive, being slightly older in the north than in the south of the basin. The structural map of this horizon preserves a record of Tertiary folding and faulting. 


\subsection{Introduction}

The map set which is included in this study (enclosures 5.1 through 5.4) is intended to supplement New Zealand Geological Survey Report G-142, Subsurface Maps of the Taranaki Basin, New Zealand (Thrasher and Cahill 1990). Portions of this previous mapping effort are also included (Appendix 1 and enclosures A.1 through A.5). In their mapping, Thrasher and Cahill treated the entire late Cretaceous sequence as one stratigraphic unit. Therefore, maps were presented for the top Cretaceous seismic horizon (both reflection time and structure) and the base of the late Cretaceous sedimentary sequence (seismic basement, both reflection-time and structure).

Chapter 4 presented evidence that the late Cretaceous sequence, at least in the Pakawau Basin, can be subdivided into two major sedimentary units: a lower sequence of early-rift, terrestrial sediments (Rakopi Formation), and an upper transgressive sequence (North Cape Formation) with a major marine component. These two units are separated by a disconformity which causes a significant seismic reflection horizon. Seismic reflection mapping of this disconformity confirms its presence throughout most of the late Cretaceous subbasins which underlie Taranaki Basin, and its seismic interpretation has resulted in the present series of maps.

Four maps have been prepared during the present study:

1. Reflection time isochrons on the mid late-Cretaceous horizon.

2. Isopachs of lower late-Cretaceous sediments.

3. Isopachs of upper late-Cretaceous sediments.

4. Structural contours on the mid late-Cretaceous horizon.

When combined with the maps from Report G-142, this additional suite of maps allows for an understanding of the basin's early-rift history. A better understanding can also be obtained of the basin's potential to source 
hydrocarbons. Cook (1988) identified the source of most Taranaki Basin hydrocarbons as terrestrial, fresh-water sediments. Because most of the late Cretaceous, organic rich, terrestrial sediments are confined to the lower-late Cretaceous sequence, the isopach of this unit (Sheet 3) is an indicator of the volume and distribution of such rocks available for sourcing petroleum.

\subsection{Data interpretation}

The seismic interpretation upon which these maps is based utilizes the same grid of reflection profiles used for the Taranaki Basin map set of Thrasher and Cahill (1990 and Enclosure A5). The seismic reflection data were tied to all seven petroleum exploration wells which penetrate the top of the lower unit.

The only seismic horizon correlated and mapped as a part of this study was the mid late-Cretaceous horizon (top of Rakopi Formation). The other horizons used to construct the isopach maps, namely seismic basement and top Cretaceous, were previously interpreted and presented in Thrasher and Cahill (1990) and are included in Appendix 1. This previous interpretation was not altered during the present mapping. The mapping techniques described in Thrasher and Cahill (1990) were also followed during the preparation of these maps.

The top Rakopi Formation seismic reflection horizon was mapped outward from the Pakawau Basin outcrop and well correlations described in Chapter 4 . Throughout the Pakawau Basin, the horizon is the boundary between distinctive seismic facies, as illustrated in Figure 4.14 (see Figure 5.1 for location). The horizon can be loop-tied without difficulty, and appears as a stratigraphic horizon with the characteristics of a time-plane. However, the hummocky, discontinuous seismic reflection character of the lower unit appears in places slightly unconformable, and the bland seismic signature of the overlying reflectors precludes internal facies recognition. It is possible that the horizon is slightly time transgressive. 


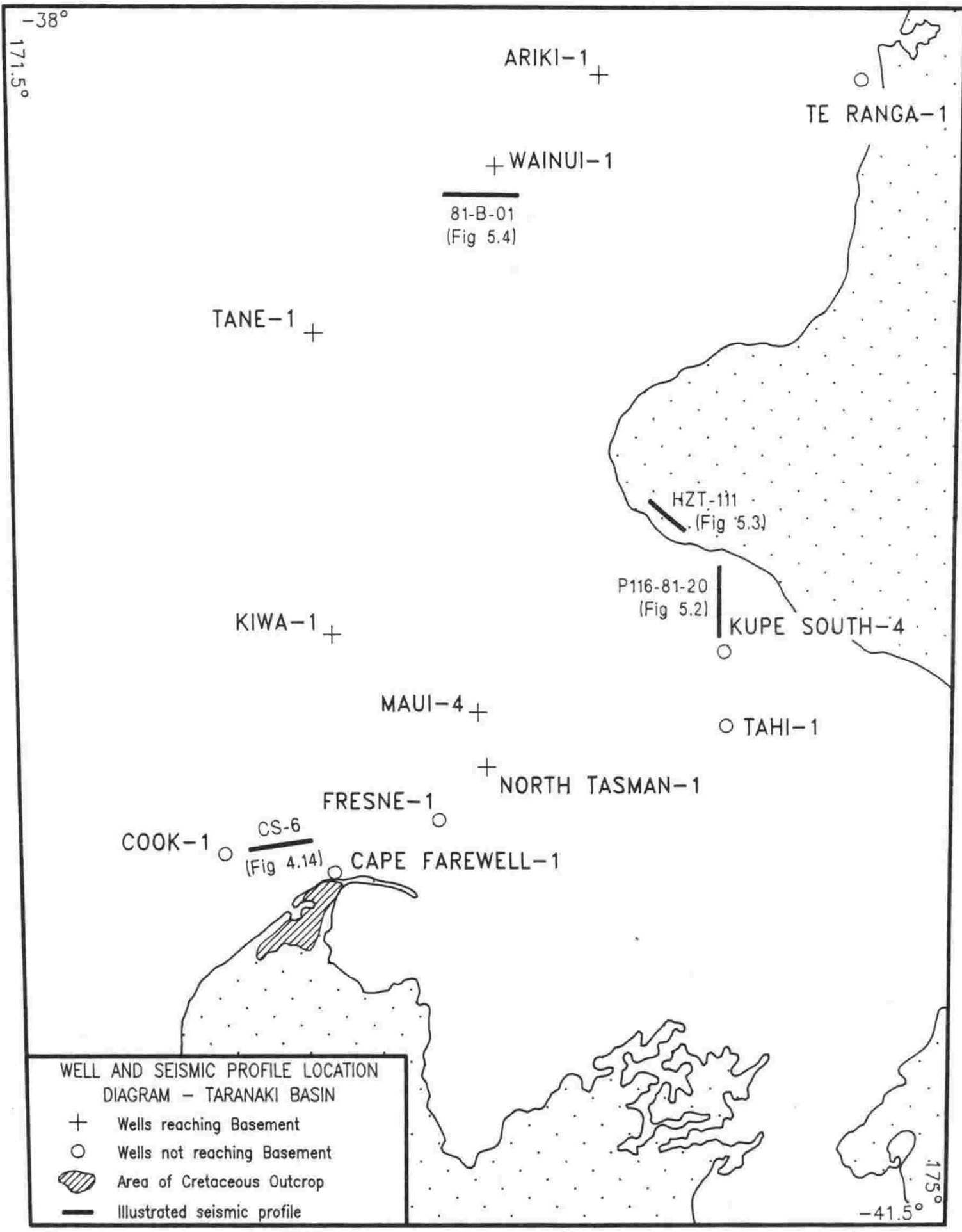

Figure 5.1 Well and seismic reflection profile location diagram. 
Outside the Pakawau Basin, the seismic reflection data were tied to wells penetrating rocks which could be correlated to the Pakawau Basin sequence. Maui-4 and Tahi-1 were easily correlated, allowing for interpretation of the mid late-Cretaceous horizon throughout the early rift subbasins of southern Taranaki Basin. The horizon was interpreted under the Taranaki Peninsula and into the North Taranaki Graben, with some difficulty in crossing the present-day shoreline (where marine and onshore data sets approach each other without overlap or transition) and some difficulty due to poor data quality. Figures 5.2 and 5.3 illustrate the seismic reflection signature of the two late Cretaceous sequences in this region, and the horizon which separates them. See Figure 5.1 for the locations of these two examples.

The Te Ranga-1 petroleum exploration well provided a tie in the North Taranaki Graben and led to the identification of the unconformity between mid Cretaceous and latest Cretaceous rocks which underlies the eastern part of the graben. The subtle nature of this unconformity, and the very poor quality of seismic reflection data in the deepest parts of the graben, make this portion of the maps the most open to interpretation error. The mid-Cretaceous rocks of the informal Taniwha Formation of Shell BP and Todd (1986) are here included, for mapping purposes, in the lower late-Cretaceous unit. Stratigraphic data from the Te Ranga-1 well indicate the presence of a thin $(50 \mathrm{~m})$ sequence of latest Cretaceus marine rocks overlying the unconformity. This sequence of rocks is too thin to identify on conventional seismic reflection profiles in the region, and has therefore not been interpreted.

The lack of well control thoughout the northerwestern portion of the study area also makes seismic interpretation in this region difficult. The only well which definitely reached stratigraphic levels equivalent to the Rakopi Formation in the northern region is Tane-1. The location of the top-Rakopi Formation equivalent in this well is not immediately obvious, due to a thick sequence of coal-bearing strata overlying basement, the upper portion of which is younger than Rakopi Formation encountered elswhere in the basin (see Chapter 6). 


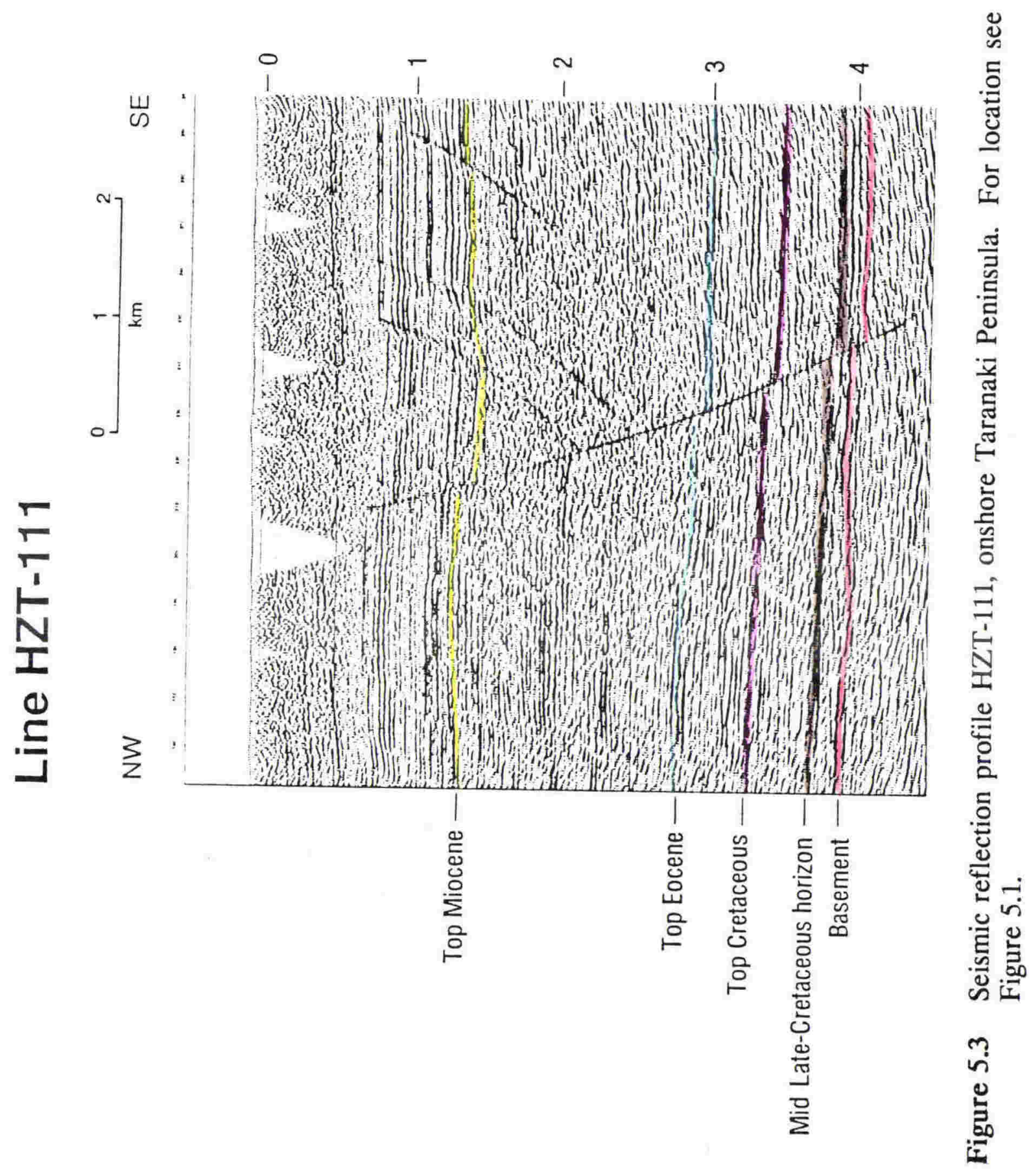


Seismic reflection interpretation, however, necessitates that the coal bearing sequence in the Tane-1 well be subdivided into two distinct units, a subdivision supported by wirelin -log data from the well (see Chapter 6 and Enclosure 6.2) North of Tane-1, and west of Wainui-1, is a region of very good seismic-reflection data quality, where the seismic signature of the late Cretaceous units is well displayed. Figure 5.4 illustrates a seismic profile, line 81-B-01, from this region. The late Cretaceous sequence can here be subdivided into two seismic facies which are remarkably similar to the sequences identified in the Pakawau Basin. Correlation of this horizon back into the only well which intersects it, Tane-1, reveals it to have an age similar, but slightly older, than that recorded in the Pakawau Basin (age control is presented in Chapter 6). This horizon was therefore taken as the top of the Rakopi Formation equivalent in this northern region, and interpreted thoughout the area. Notice that the upper late Cretaceous seismic sequence on the profile illustrated in Figure 5.4 records the progressive onlap of a transgressive sequence. Onlap relationships on the seismic grid in this area show that this transgression proceeded from northwest to southeast.

Seismic-reflection velocity analyses, conducted during seismic data processing to obtain Common Depth Point (CDP) stacking velocities, can be very useful in locating and confirming significant seismic units and horizons. The distinctive two-part seismic stratigraphy of the late Cretaceous sequence in the region north of the Tane-1 well is confirmed by velocity analyses, with remarkable clarity. Figure 5.5 is a velocity analysis from line 81 -B-01 (Figure 5.4), illustrating the velocity and semblance signature for this region. Normal-move-out (NMO) velocities are quite low here, not exceeding $3000 \mathrm{~m} / \mathrm{sec}$ at a two-way-time of 4.5 seconds. The probable cause of this low velocity is that the thick accumulation of post-Miocene progradational sediments has not been in place long enough to be compacted, or fully compact the underlying sedimentary sequence. 
147

$\perp M \perp$ SPUOJәS

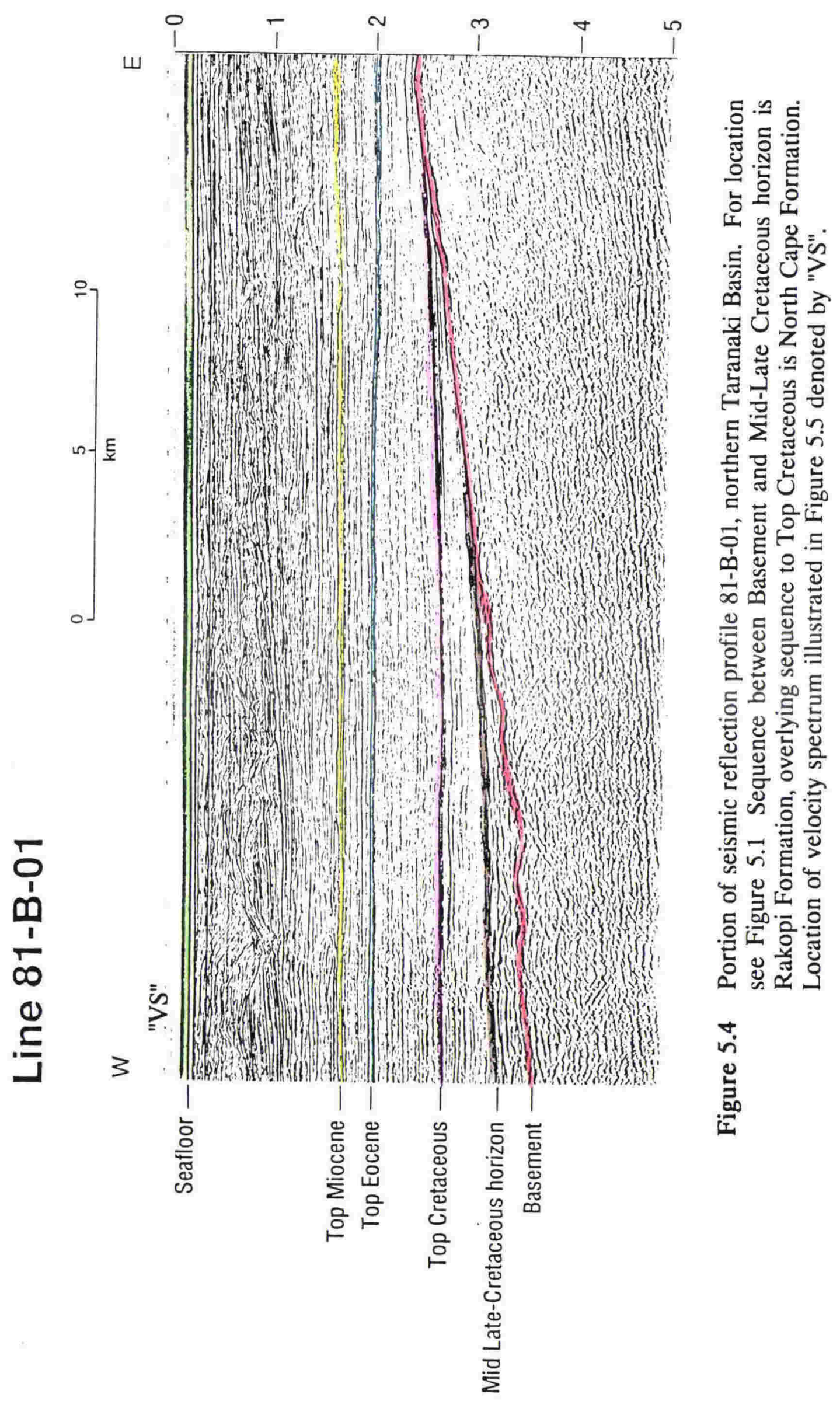


On Figure 5.5 the very distinctive velocity and semblance signatures of the upper and lower late-Cretaceous seismic units are illustrated. The upper unit has very poor statistical velocity coherence, with almost no good NMO velocity events. The semblance and amplitude traces indicate that the best semblance in the unit is from a reflector at 3.7 seconds; however this event falls below the NMO velocity trend on the spectra plot, indicating that it arises from a multiple reflection event.

In contrast, the lower late-Cretaceous unit demonstrates very good velocity spectral events, with high semblance. This indicates the presence of sharp acoustic impedence contrasts within the unit. The location of seismic basement is readily confirmed on this velocity analysis by the complete lack of velocity coherence beneath the last major semblance peak at 4.5 seconds. Basement thus marks the end of primary seismic reflection energy being returned to the surface.

Interpreting the mid late-Cretaceous seismic horizon in the deep grabens east of the Wainui-1 well and in the North Taranaki Graben was accomplished using character ties across the highstanding basement blocks, and meticulous looping and tying of seismic profiles. Even so, the lack of well ties in this region means the interpretation presented here must be viewed with some caution.

The two late Cretaceous seismic units, separated by the mid late-Cretaceous seismic horizon can, in general, be characterized by their seismic reflection signature. The lower unit is characterized by high amplitude, hummocky, often-discontinuous reflectors. The upper unit is characterized by a much more uniform, parallel-layered, and frequently near-reflection-free seismic signature. This separation of the late Cretaceous into two seismic reflection facies was noted by Thrasher (1988), who associated the lower unit with terrestrial sediments and the upper unit with marine sediments. 


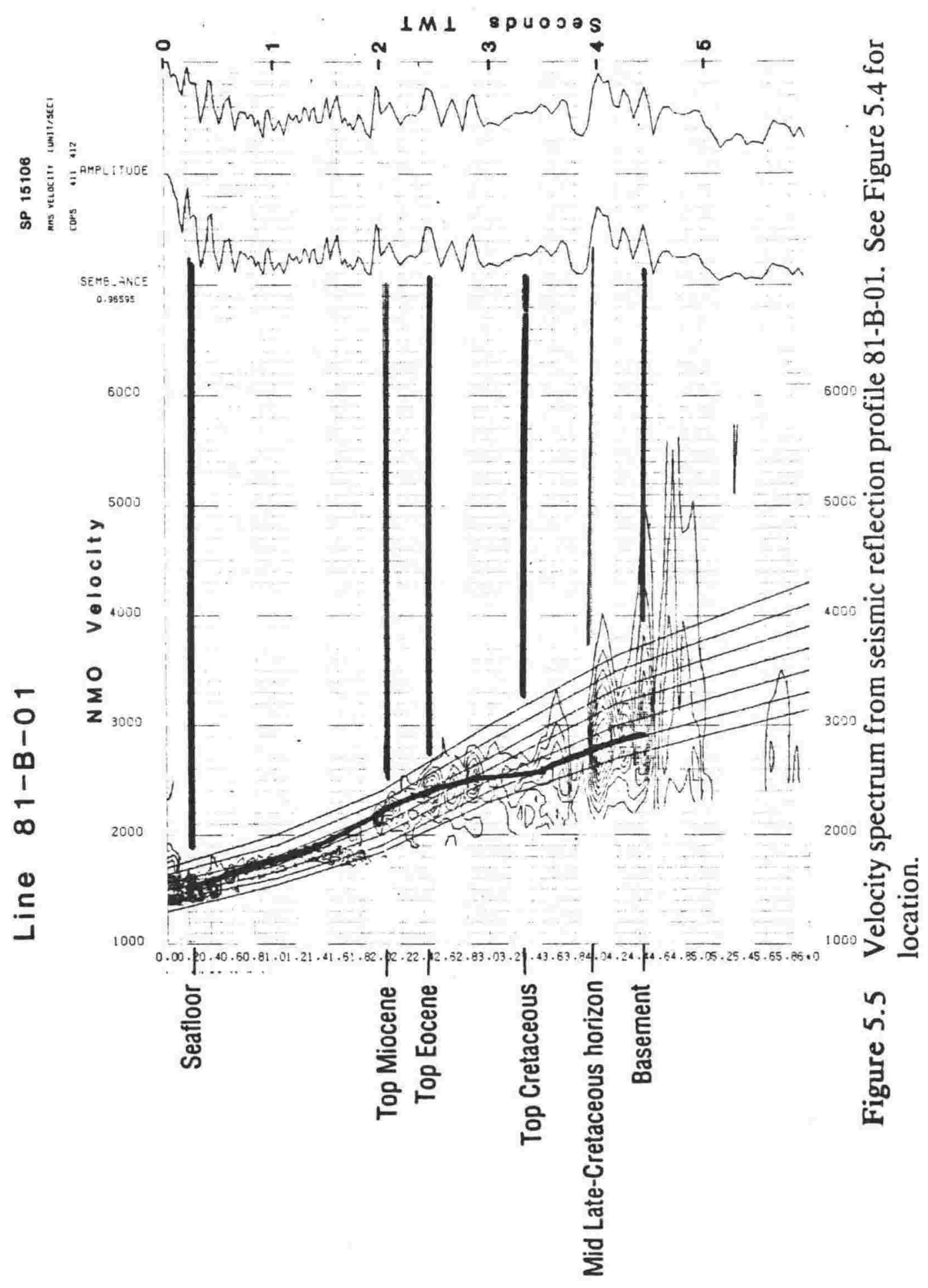


Although most of the 12 wells which have recovered samples of the upper late-Cretaceous unit have recorded some marine influence on sedimentation, the unit is not ubiquitously marine. The unit contains significant non-marine sediments, and often has the high-amplitude, discontinuous reflection character associated with terrestrial sediments (see Chapter 7).

Where possible the mid late-Cretaceous seismic horizon was interpreted throughout Taranaki Basin as if it were a time-plane. The reflector pinches out against basement highs in many places, indicating that those highs were exposed at the time. In some places, especially on the Western platform, treating the seismic horizon as a time plane, and tracing it to pinch-out points against paleo-basement-highs, contradicted the seismic character definition of the two late Cretaceous seismic units. On the Western Platform, the thin (generally less than $500 \mathrm{~m}$ ) latest Cretaceous sediments of the upper unit have a "terrestrial" seismic appearance and rest directly on a gently undulating basement surface. The significance of this and other seismic facies anomalies will be discussed more fully in Chapter 7.

Seismic reflection profiles interpreted for the mid late-Cretaceous horizon were digitized at the same navigation fix points (approximately every kilometre) as for the previous seismic interpretion (Thrasher and Cahill 1990). This allowed for the two interpretations to be merged as a digital data set for map posting and numerical manipulation, such as isopach calculation and depth conversion.

\subsection{Depth conversion}

Depth conversion is the process of converting seismic reflection data from two-way-reflection-time measurements to thickness and depth values. The method used in this study is that documented in Thrasher (1988) and Thrasher and Cahill (1990, copy in Appendix 1). This method utilizes average interval- 
velocity equations, determined from exploration-well velocity surveys, for each seismically defined unit. These equations relate the thickness of the unit to the interval-travel-time of seismic waves passing through the unit. Intervaltravel-times from seismic reflection profiles can be converted to isopach thickness using the equation relevant to the particular interval.

The equations relating thickness to interval-travel-time are derived by statistical analysis of time-versus-thickness data from petroleum exploration wells. Structure values, representing the depth to a particular horizon, are obtained by summing the isopach values for all of the units above the horizon for which structure values are being calculated.

For the maps of the present study, a linear regression analysis was performed on the thickness versus interval-travel-time data from wells which intersected the upper and lower late-Cretaceous units. The data for this analysis are listed in Table 5.1. Figures 5.6 and 5.7 are graphs of the time-thickness relationships. Interval velocities of $4.0 \mathrm{~km} / \mathrm{sec}$ for the upper unit and $4.4 \mathrm{~km} / \mathrm{sec}$ for the lower unit were obtained by linear regression and used to calculate isopach values. Higher regressions, such as binomial, did not produce a better fit, due to the scatter in the data and the fewer degrees of freedom. These interval velocities compare very well with those previously reported for the entire late Cretaceous interval of $4.3 \mathrm{~km} / \mathrm{sec}$ (Thrasher 1988) and $4.0 \mathrm{~km} / \mathrm{sec}$ (Thrasher and Cahill 1990).

Structural values, upon which Sheet 4 is based, were calculated by adding the isopach values for the upper late-Cretaceous unit to those values computed for structure of the top Cretaceous horizon by Thrasher and Cahill (1990). The preparation of this top Cretaceous map is discussed in Appendix 1, and the map is included as Enclosure A.4. 


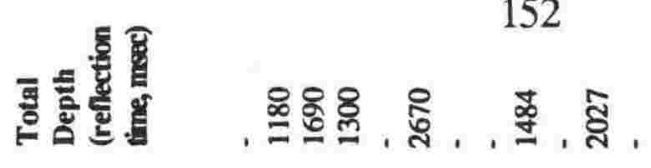

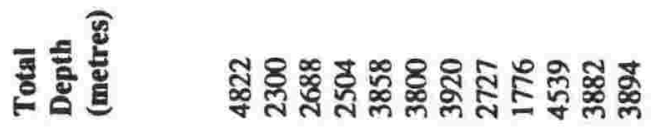

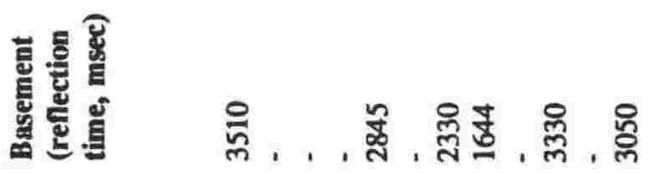

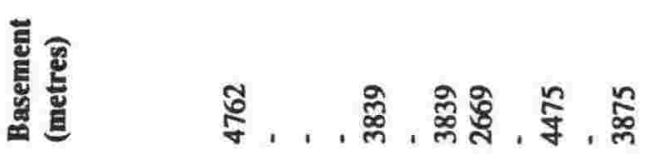

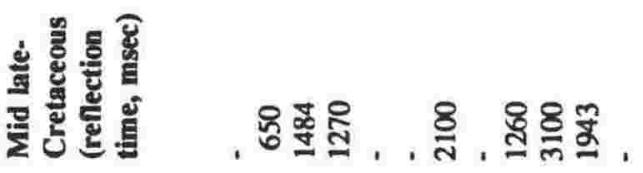

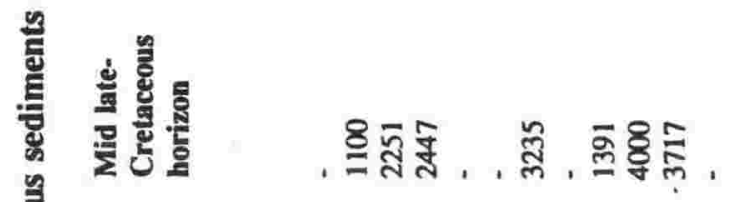

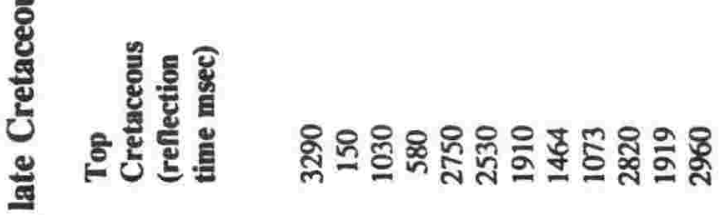

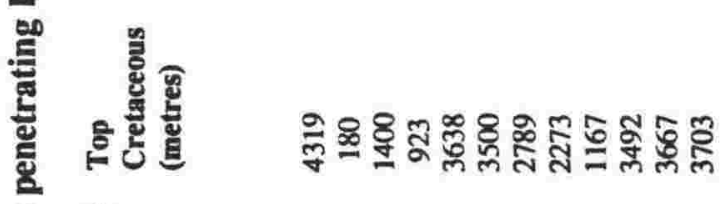

厸

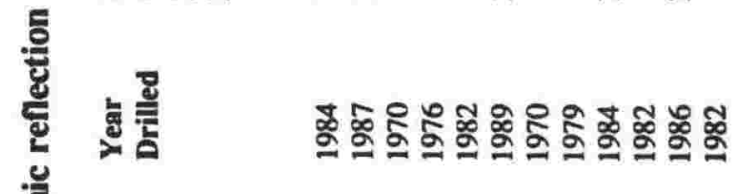

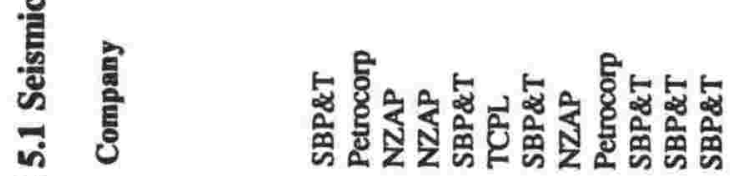

논

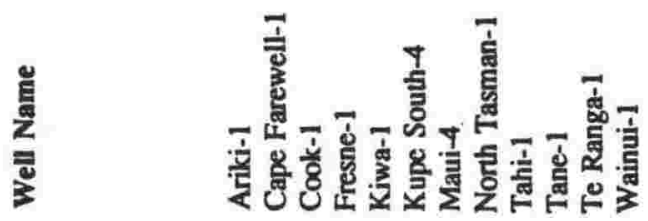




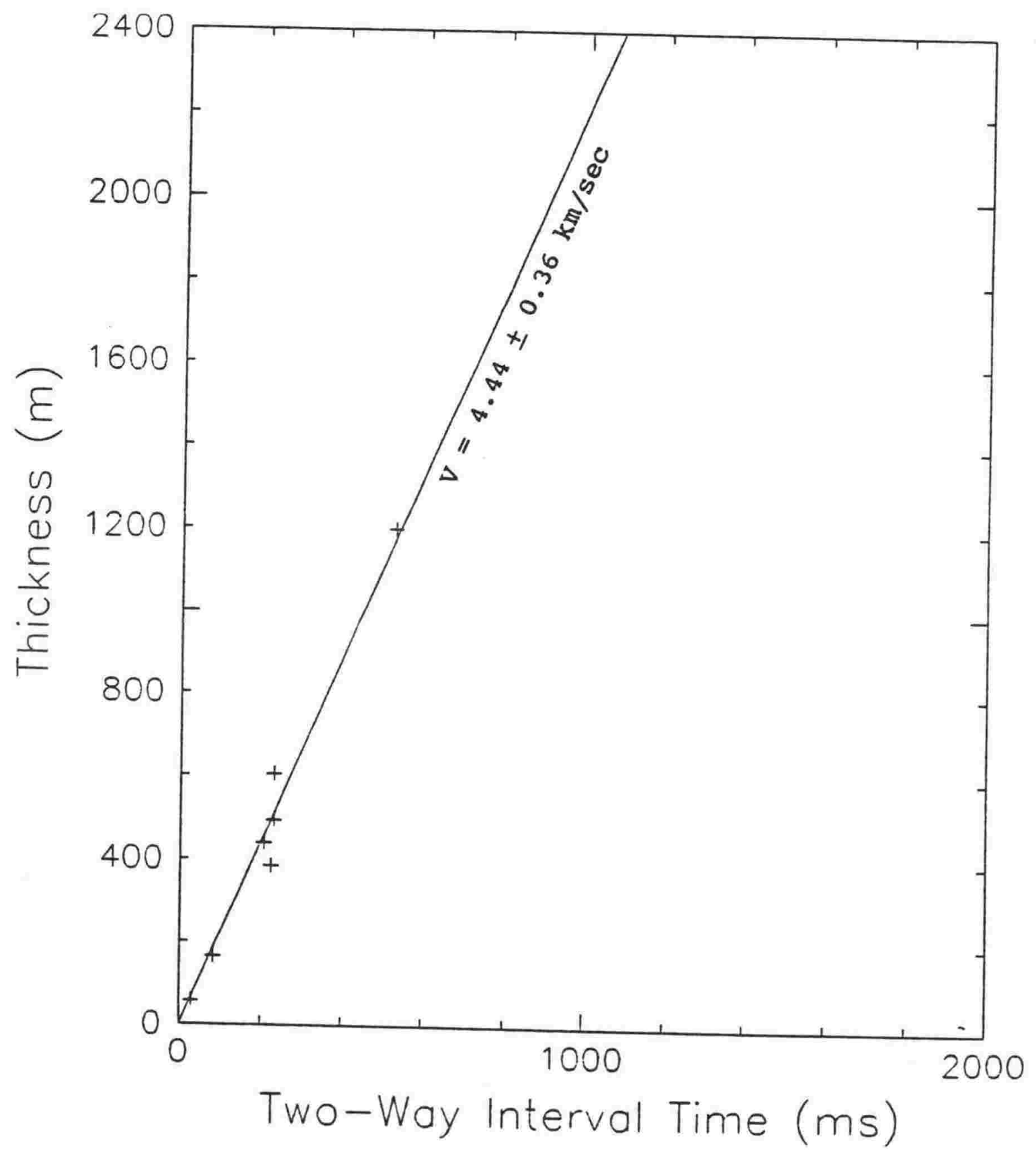

Figure 5.6 Thickness versus interval-travel-time for the lower late-Cretaceous unit, Taranaki Basin. Interval velocity $=4.44 \mathrm{~km} / \mathrm{sec}$. Well used: Tahi-1, Maui-4, Fresne-1, Cape Farewell-1, Cook-1, Tane-1, Te Ranga-1. 


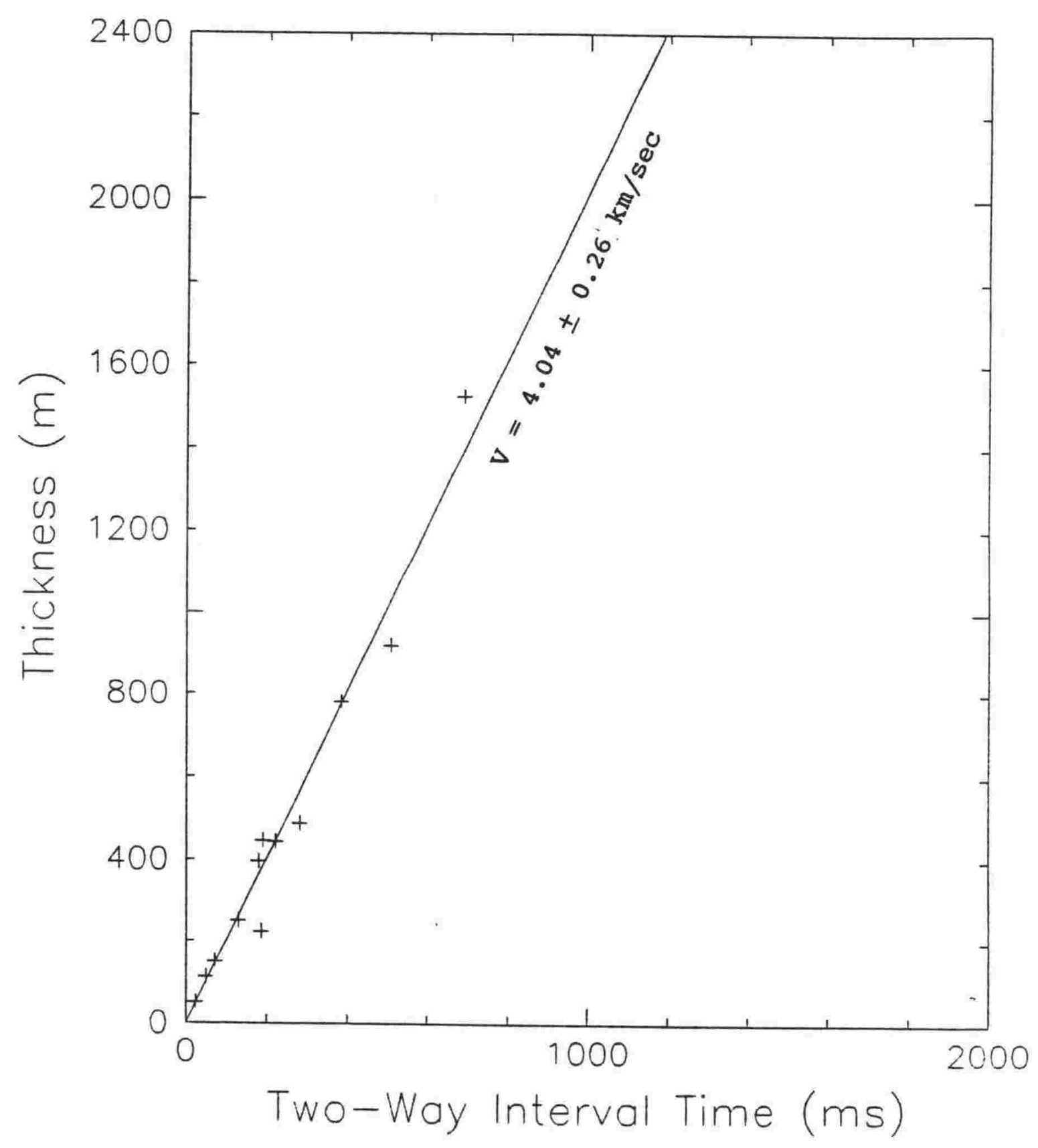

Figure 5.7 Thickness versus interval-travel-time for the upper late-Cretaceous unit, Taranaki Basin. Interval velocity $=4.04 \mathrm{~km} / \mathrm{sec}$. Well used: Tahi-1, Maui-4, North Tasman-1, Fresne-1, Cape Farewell-1, Kiwa1, Cook-1, Tane-1, Wainui-1, Ariki-1, Te Ranga-1, Kupe South-4. 


\subsection{Map production}

Once digital values for the four maps presented with this study were calculated, those values were computer posted for contouring at a scale of 1:200 000. These posted maps were hand contoured by the author.

All four hand-contoured maps were digitized by GECO-PRAKLA at their Wellington computer facility, and then returned to the author for checking and correction. The maps, like those of Thrasher and Cahill (1990), are printed in limited production runs on the colour Versatec plotter at GECO-PRAKLA. The maps are presented at a scale of 1:500 000 on a New Zealand Map Grid projection.

\subsection{Conclusions}

Interpretation of the mid late-Cretaceous seismic reflection horizon depicts a regional surface, separating two depositional sequences. Consideration of this surface and the isopachs of units above and below it aid in understanding the geologic history of rifting and subsequent deformation of Taranaki Basin. The lower late-Cretaceous isopach map (Enclosure 5.2) illustrates the early-rift history of the basin. Taranaki Basin first formed as a series of separate subbasins, such as the Pakawau Basin, controlled by a few major north-south and northeastsouthwest faults. Faulting formed half-graben basins by rotation of the hanging wall into the fault, indicating the listric nature of these faults. These basins contain up to $3000 \mathrm{~m}$ of sediment.

In the northern region of the Western Platform a broad area (100 km wide) of subsidence unbroken by faulting was also receiving sediment. As mentioned in Chapter 3, the New Caledonia Basin was probably forming by associated rifting at the same time, and related subsidence may be responsible for this sediment accumulation. 
The upper late-Cretaceous unit (Enclosure 5.3) dępicts_a ${ }_{r}$ Deriod of much more regional sedimentation, in which sediments onlapped onto basement over large areas. The same faults still controlled basin development, and fixed the position of adjacent depocentres. Sediment thickness maxima are less than for the lower unit, and rarely exceed $1500 \mathrm{~m}$.

The structure map (Enclosure 5.4) is the most difficult to interpret, because it preserves a record of the deformation of the mid late-Cretaceous horizon since deposition of the lower unit. This horizon outcrops in Northwest Nelson, and descends to depths in excess of $7000 \mathrm{~m}$ in the Manaia Graben and north of the Taranaki Peninsula.

Tertiary compressive deformation is recorded in the anticlinal folds which have resulted in the Cook, Fresne and Maui-4 structures, and in the Manaia Anticline between the Tahi and Kapuni structures. Continued subsidence is recorded in the synclinal form of the northern Western Platform, plunging down into the New Caledonia Basin, and in the synclines and normal faults of the North Taranaki and Moa graben complexes.

\subsection{References}

Cook, R.A. 1988: The geology and geochemistry of the crude oils and source rocks of western New Zealand, PhD thesis, Victoria Universtiy of Wellington.

Shell BP and Todd 1986: Well resume Te Ranga-1 PPL 38107. Unpublished open-file petroleum report 1197, filed at DSIR Geology and Geophysics, Lower Hutt.

Thrasher, G.P. 1988: The intrepretation of seismic reflection data from the Western Platform region of Taranaki Basin. Energy exploration and exploitation, Vol 6, No 2: 136-150. 
Thrasher, G.P.; Cahill, J.P. 1990: Subsurface maps of the Taranaki Basin region, New Zealand. New Zealand Geological Survey report G-142 (copy in Appendix 1). 


\section{CHAPTER 6: SUBSURFACE STRATIGRAPHY OF LATE CRETACEOUS ROCKS, TARANAKI BASIN}

\subsection{Chapter abstract}

The late Cretaceous sedimentary sequence of Taranaki Basin can be conveniently classified into formations and constituent members by utilizing a variety of subsurface correlation techniques, including seismic reflection mapping, wireline logs, and lithologic, biostratigraphic and geochemical data. Stratigraphic correlation is complicated by the large distances between many of the petroleum exploration wells used to provide control for seismic mapping, and the geographically discontinuous depositional systems.

The oldest known sedimentary rocks in Taranaki Basin are the Taniwha Formation strata in the Northern Taranaki Graben. These terrestrial and marginal marine rocks are probably pre-rift sediments, although their history, and extent, is poorly understood.

Throughout most of the Taranaki Rift the lowest stratigraphic unit is the Rakopi Formation of Haumurian Age. The Rakopi Formation consists of terrestrial conglomerates and coal measures deposited in local rift basins, and is up to 2000 $\mathrm{m}$ thick. The carbonaceous content of the Rakopi Formation is high and it is a probable hydrocarbon source rock.

During the latest Haumurian, about 70 million years ago, the Taranaki Rift was flooded by a marine transgression which propagated from north to south, resulting in the deposition of the North Cape Formation. These mainly shallow marine and paralic deposits are up to $1500 \mathrm{~m}$ thick and underlie much of Taranaki Basin. 
The North Cape Formation has three defined members. The Puponga Member is a latest Cretaceous, coal-bearing terrestrial unit confined to Pakawau Basin. This member is present in outcrop and in the Cape Farewell-1 and Fresne-1 wells. The Wainui Member is another coal-bearing unit, but confined to the northwest corner of Taranaki Basin and present in wells Wainui-1 and Tane-1. Both of these members have lateral equivalents in other portions of the basin. The Fresne Conglomerate Member is a fault-proximal deposit encountered only in the Fresne-1 well.

Overlying the late Cretaceous strata are the Kapuni Group, a Paleogene regressive terrestrial sequence, and its lateral marine equivalent, the Moa Group.

\subsection{Introduction}

Much of the stratigraphic nomenclature for the late Cretaceous strata of Taranaki Basin is based on outcrops in Northwest Nelson. This nomenclature and its history were discussed in in Chapter 4 . The present chapter extends that stratigraphic system thoughout the rest of Taranaki Basin.

Stratigraphic correlations are presented here within a general lithostratigraphic framework. Unfortunately, the rigorous methodology for lithostratigraphic formulation, as detailed in the International Stratigraphic Guide (Hedberg 1976) is difficult to apply in subsurface studies. Lithologic observations cannot be directly made, but instead must be deduced from well cuttings, drilling data and wireline logs. However, a wide range of other geological and geophysical data can be applied to the problem of geologic correlation. The range of information considered in formulating the stratigraphy presented here, and determining the distribution of stratigraphic units, includes interpreted lithology, wireline-log response, age, environment of deposition, biostratigraphic correlations, seismic reflection character and correlations, total organic carbon (TOC) content, and precedence of publication. 


\subsection{Late Cretaceous stratigraphy of Taranaki Basin}

In this study, the differentiation between formations and members is based largely on regional continuity. If a sequence of rocks represents the major sedimentary style of most of Taranaki Basin, or its subbasins, during deposition of those rocks, then formation status is considered appropriate. If a sequence of rocks represents a local sedimentary environment of a minor portion of the basin, then member status is considered more appropriate. Figure 6.1 is a generalized stratigraphic column for the late Cretaceous strata of Taranaki Basin.

Because this study is aimed at understanding the late Cretaceous geology of Taranaki Basin, the post-Cretaceous stratigraphy is presented only at group level, and the published stratigraphic schemes of Palmer (1985) and King (1988a and 1988b) are accepted.

\section{Kapuni Group}

The Kapuni Group was upgraded from the Kapuni Formation by Palmer (1985) to formalize the grouping of Paleocene and Eocene coal measure formations in the subsurface of Taranaki Basin. These sediments had long been grouped informally by petroleum explorers.

King (1988a) expanded the usage of Kapuni Group to include the coal measure sequences of similar age outcropping in Northwest Nelson. This expansion has left an awkward legacy in the outcrop sequence, in that the Farewell Formation of Suggate's (1956) original Pakawau Group is assigned by King's definition to the Kapuni Group. The Farewell Formation was deposited during the Paleocene, but is lithologically similar to the underlying Cretaceous Pakawau Group. King (1988a) considered the lateral equivalents of the Farewell Formation in the subsurface to be more akin to the Kapuni Group, however. 
SOUTH

NORTH

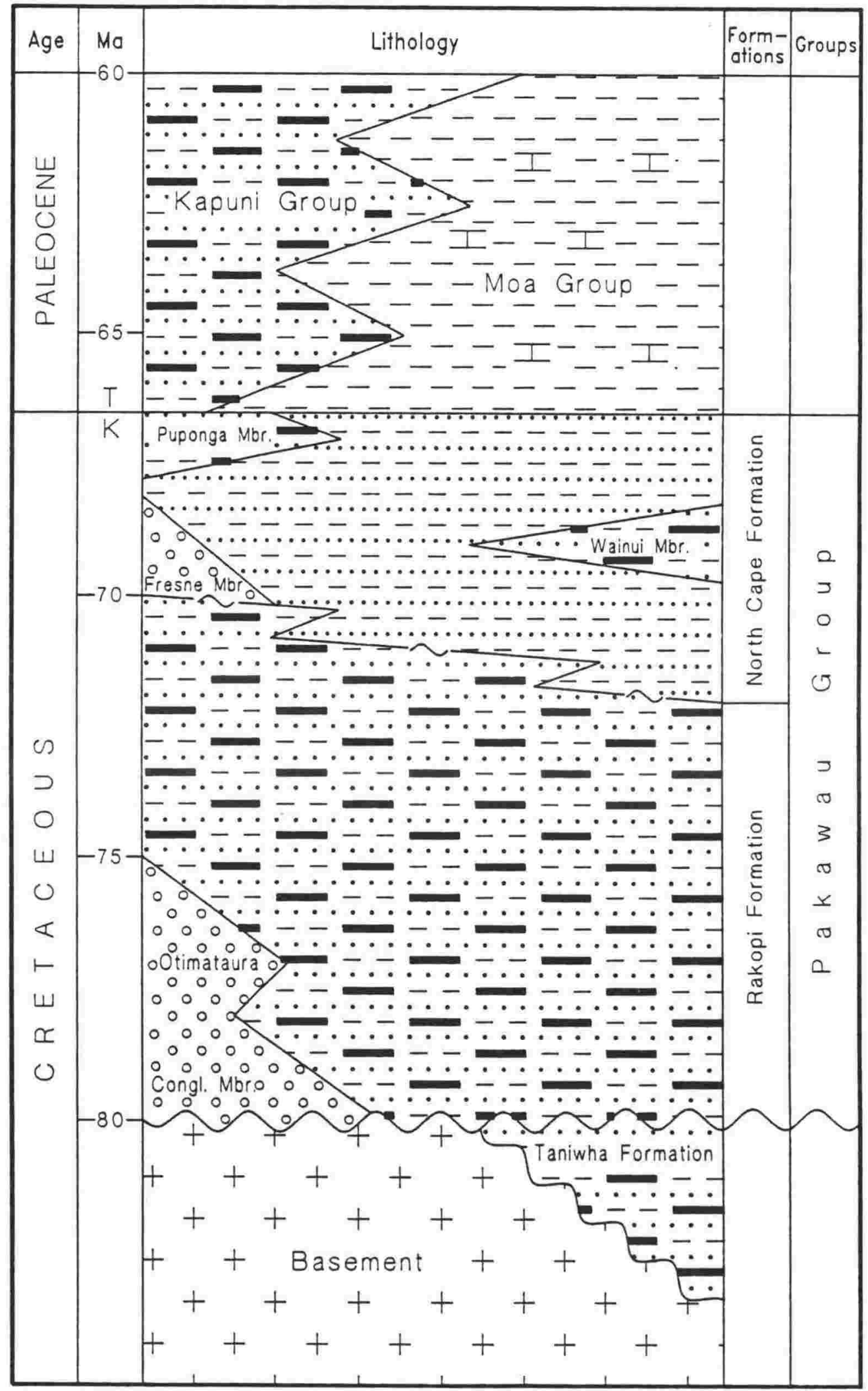

Figure 6.1 Generalized stratigraphic diagram of late Cretaceous rocks, Taranaki Basin. 
The present study concentrates on the late Cretaceous history of the region, and whether the Farewell Formation is included in the Pakawau Group or the Kapuni Group does not materially affect its conclusions. However, readers should be aware of the potential for confusion and controversy surrounding the positioning of the Farewell Formation into the Taranaki Basin stratigraphic framework.

\section{Moa Group}

The Moa Group has never been formally defined. The name was first used by King (1988b) where it is described as an entirely marine lateral equivalent of the Kapuni Group. Subsequent authors (for example King 1990; van der Lingen and Smale 1990; King and Thrasher in press) have used the name for a series of fine-grained, calcareous siltstones and sandstones which were deposited widely through the northern portions of Taranaki Basin during the Paleogene.

\section{Pakawau Group}

The Pakawau Group takes its name from Northwest Nelson, where the group is exposed in outcrop. The stratigraphy of the outcrop section, and its correlation to the subsurface of the Pakawau Basin, are discussed in Chapter 4. Following the usage of King (1988a), the Pakawau Group is here restricted to the late Cretaceous. Within the subsurface, the Pakawau Group is subdivided into two formations, the North Cape Formation (modified here) and the Rakopi Formation (new), which are further subdivided into various members.

North Cape Formation: This is the upper formation of the Pakawau Group. The usage of North Cape Formation has been expanded from Suggate (1956) and is used here to denote a thick sequence of siltstone, sandstone and conglomerate, with minor coal. Carbonaceous content is very low and rarely exceeds $1 \%$ TOC, except in the Puponga and Wainui members where coal beds and carbonaceous shales are common. The North Cape Formation is here considered to represent 
a transgressive sequence, predominantly deposited in shallow marine to paralic conditions. Three members are recognized:

Puponga Member (after Suggate 1956): The uppermost portion of the North Cape Formation in the Pakawau Basin, this coal-bearing unit represents the establishment of lower coastal plain, coal-forming conditions laterally equivalent to and overlying marine transgressive sedimentation. Suggate (1956) refers to this unit as the Puponga Formation. The unit is here given member status due to its limited lateral extent.

Wainui Member (new name): This is a coal-bearing unit both laterally equivalent to, and underlying, the marine transgressive deposits. This member is present in the northwest portion of Taranaki Basin, where it occurs in the Wainui-1 and Tane-1 wells. Lateral equivalents occur elsewhere in the basin. The type section is from $3762 \mathrm{~m}$ to basement $(3875 \mathrm{~m})$ in the Wainui-1 well (Shell BP and Todd 1982a). This unit represents lower coastal plain to paralic sedimentation during the late Haumurian regional transgression.

Fresne Conglomerate Member (new name): Present in the Fresne-1 well (New Zealand Aquitaine Petroleum 1976) only, this $900 \mathrm{~m}$ thick (1550 m to 2447 $\mathrm{m})$ sequence of sands and conglomerates is most likely a localized fault-proximal deposit equivalent to North Cape Formation sandstones.

Rakopi Formation: This is the lower formation of the Pakawau Group, and was defined in Chapter 4. It is considered to represent a syn-rift, terrestrial, graben-fill facies. The formation is predominantly sandstone, with numerous coal seams and subordinate conglomerate, silt, and carbonaceous shale. The age is Haumurian. Most of the formation is here left undifferentiated, with only one member recognized: 
Otimataura Conglomerate Member (after Bishop 1971): The lowest portion of the Rakopi Formation within the Pakawau Basin consists predominantly of conglomerate, which has been given member status in this study (Chapter 4). This member is recognized in outcrop, in the Rakopi Borehole, and in the Cape Farewell-1 petroleum exploration well.

\section{Tahi Group}

The Tahi Group was first named by King (1988a) to accommodate a growing number of reports of Cretaceous-age marine rocks in petroleum exploration wells in Taranaki Basin. The original group was not formally defined nor subdivided into formations. This lack of subdivision into formations undermines group status for the Tahi Group.

The present study has found that subsurface sequences previously assigned to the Tahi Group (King 1988a) are not distinguishable on lithology, carbonaceous content, wireline log signature, age, environment of deposition or seismic character from portions of the previously defined North Cape Formation. The term Tahi Group has therefore not been used in this study, as the unit does not warrant group status and at the formation level the term North Cape Formation has precedence.

Taniwha Formation: The name "Taniwha Formation" was proposed by Shell BP and Todd (1986) in the well completion report for the Te Ranga- 1 well. The strata are middle Cretaceous in age, of a coal-bearing marginal marine facies, and have only been encountered in that well. The significance of these rocks is uncertain, but they are most likely pre-rift rocks, and thus not of major relevance to the present study of rift-controlled sedimentation. The Taniwha Formation is discussed in sections 5.3 and 7.3. 


\section{Basement}

The definition for "basement" used in Chapter 4 on the Pakawau Basin is continued here. "Basement" denotes those rocks lying beneath the major unconformity surface upon which Cretaceous and later sedimentary rocks were deposited. Basement within Taranaki Basin is predominantly pre-Cretaceous igneous and metamorphic rocks, which were subjected to subaerial erosion prior to deposition of the Cretaceous and Cenozoic sedimentary sequence.

\subsection{Well correlation}

Twelve petroleum exploration wells penetrate late Cretaceous rocks in Taranaki Basin. All but Cape Farewell-1 were located offshore. No wells located on Taranaki Peninsula have drilled deeply enough to reach the late Cretaceous. Because the wells that have sampled the late Cretaceous are very widely spaced (up to $100 \mathrm{~km}$ apart), correlation of rock sequences into a stratigraphic framework is difficult and uncertain.

Seismic reflection mapping helps stratigraphic correlation between wells, however neither stratigraphic nor seismic reflection data should be interpreted independently. The correlations of individual wells to the stratigraphy discussed above is very dependent on the seismic reflection structural and facies mapping discussed in chapters 5 and 7.

Enclosure 6.1 illustrates the correlation between petroleum exploration wells in Taranaki Basin which penetrated late Cretaceous rocks. Specific notes regarding the correlation of units and the assignment of strata to particular units are as follows:

Pakawau Basin. Subsurface correlations within the Pakawau Basin were documented in Chapter 4 on the geology of the Pakawau Basin. That chapter 
includes details on the stratigraphic assignments and correlations for petroleum exploration wells Cook-1, Cape Farewell-1 and Fresne-1, as well as for the onshore outcrop.

North Tasman-1. Top Cretaceous in North Tasman-1 is at approximately 2273 m (King 1988a). This horizon is a contact between overlying coal-bearing silty sandstone and underlying marine sandstone with minor silt and very little carbonaceous material. In the well completion report (New Zealand Aquitaine Petroleum Ltd 1979) the entire sequence from base Oligocene at $2002 \mathrm{~m}$ to basement at $2669 \mathrm{~m}$ was assigned to the undifferentiated Pakawau Group. King (1988a) revised the stratigraphic nomenclature of the well by assigning the Paleocene and Eocene terrestrial coal-bearing rocks above $2273 \mathrm{~m}$ to the Kapuni Group. The occurance of this $270 \mathrm{~m}$ thick interval of terrestrial strata overlying the late Cretaceous marine strata indicates a regressive event starting very near the Cretaceous-Tertiary boundary, such as that responsible for the deposition of the Farewell Formation in the Pakawau Basin to the southwest.

The late Cretaceous sequence can be divided into two units. The upper non-carbonaceous sandstone $(2273-2430 \mathrm{~m})$ is here assigned to the North Cape Formation, because of its silty-sand lithology, non-carbonaceous nature, stratigraphic position, and shallow marine environment of deposition. The lower unit ( 2430 to $2669 \mathrm{~m}$ ) is predominantly sandstone with conglomerates, shales, and many thin coal beds. Seismic mapping shows this lower unit to be laterally continuous with the late Cretaceous sandstones of the North Cape Formation in Maui-4. The lower unit is therefore tentatively correlated as an equivalent of the Wainui Member, which is considered to be a lower coastal plain facies, underlying the latest Cretaceous transgression, within the North Cape Formation.

Tahi-1. The well completion report for Tahi-1 (Petroleum Corporation of New Zealand Ltd. 1984) documents a major unconformity penetrated at $1167 \mathrm{~m}$. This unconformity separates Neogene rocks from Cretaceous rocks, with the entire Paleogene unrepresented. The seismic-reflection derived maps of Thrasher and 
Cahill (1990) can be used to estimate that about $600 \mathrm{~m}$ of latest Cretaceous rocks and about $500 \mathrm{~m}$ of Paleocene and Eocene rocks were removed by Miocene erosion, by comparing the thickness of off-structure, uneroded sequences with those encountered in the well.

Immediately underlying the unconformity are more than $200 \mathrm{~m}$ of non-carbonaceous, silty marine sandstone of late Cretaceous age. Petroleum Corporation of New Zealand (1984) assigned these rocks to the undifferentiated Pakawau Group, and King (1988a) named his informal Tahi Group after these strata. For the present study, the sequence from the unconformity at $1167 \mathrm{~m}$ to $1391 \mathrm{~m}$ is assigned to the North Cape Formation of the Pakawau Group.

From $1391 \mathrm{~m}$ to TD $(1776 \mathrm{~m})$ the well penetrated an interbedded terrestrial sequence of conglomerate, sandstone, mudstone and coal. Basement was not reached. This lower unit is here assigned to the Rakopi Formation of the Pakawau Group. This assignment is based on the conglomeratic and carbonaceous nature of the unit, its stratigraphic position, and its seismic reflection character (see Chapter 7).

Kupe South-4. This well lies about $23 \mathrm{~km}$ north of Tahi-1, and well data became open-file in late 1991 (TCPL Resources Ltd. 1989). Because the well was drilled down the plunge of the Manaia Anticline from Tahi-1, much less section was removed by the erosion which followed Miocene formation of the anticline. Top Cretaceous is at about $3500 \mathrm{~m}$, within a coal-bearing sandstone and siltstone unit which is assigned to the Puponga Formation (here called the Puponga Member of the North Cape Formation) in the well completion report (TCPL Resources Ltd. 1989). Lateral continuity with the type locality for the Puponga Member (near Cape Farewell) cannot however be demonstrated. The lithological characteristics and stratigraphic position of this unit are very much like those of the Puponga Member, therefore the sequence from $3500 \mathrm{~m}$ to $3660 \mathrm{~m}$ is considered a Puponga Member equivalent. 
From $3660 \mathrm{~m}$ to TD at $3800 \mathrm{~m}$ in Kupe South-4 is a fine-grained calcareous sandstone, which TCPL Resources Ltd. (1989) assigned to the undifferentiated Tahi Group. This unit is here assigned to the North Cape Formation of the Pakawau Group. This assignment is based on the sandy to silty lithology, non-carbonaceous nature, stratigraphic position and marine environment of deposition of the unit. Basement was not reached by this well.

Maui-4. King (1988a) established the top Cretaceous in Maui-4 to be at $2789 \mathrm{~m}$. This is the contact between overlying coal-bearing terrestrial sandstones of the Kapuni Group and underlying non-carbonaceous marine sandstones of King's (1988a) informal Tahi Group. In the present study the marine sandstone unit from 2789 m to $3235 \mathrm{~m}$ is assigned to the North Cape Formation of the Pakawau Group.

From $3235 \mathrm{~m}$ to basement at $3839 \mathrm{~m}$ is a $600 \mathrm{~m}$ thick unit of terrestrial, coal-bearing sediments of late Cretaceous age (Shell BP and Todd 1970). This unit can be subdivided into 3 sequences. The uppermost ( 3235 to $3377 \mathrm{~m}$ ) and lowermost ( 3636 to $3839 \mathrm{~m}$ ) sequences are very carbonaceous, fine grained rocks with numerous thin coal seams. Between these (3377 to $3636 \mathrm{~m}$ ) are conglomeratic sandstones and shales with lesser carbonaceous material and no coal beds. All three sequences appear to be wholly terrestrial. In the present study, the three sequences are assigned to a single unit, the Rakopi Formation of the Pakawau Group. It is possible that the true stratigraphic correlation with the Rakopi Formation is the lowermost coal-bearing unit (3636 to $3839 \mathrm{~m}$ ) and that the upper two sequences may belong in the North Cape Formation. This uncertainty is due to the lack of a direct seismic reflection tie from Maui-4 to any other well with the mid late-Cretaceous horizon, and the poor age control in the Maui-4 well.

Kiwa-1. Top Cretaceous in Kiwa-1 is approximately 3638 m (King 1988a). Basement is at $3839 \mathrm{~m}$. The $200 \mathrm{~m}$ thick sequence from $3638 \mathrm{~m}$ to basement consists of shallow marine sandstones, with some calcareous cementation near the 
top. Although they were originally assigned to the Pakawau Group (Shell BP and Todd 1982b), King (1988a) reassigned these rocks to the informal Tahi Group. In the present study they are assigned to the North Cape Formation of the Pakawau Group. This assignment is based on their sandy character, lack of significant carbonaceous material, and shallow marine depositional environment. Kiwa-1 is located $75 \mathrm{~km}$ north of Cape Farewell, where the North Cape Formation can be observed in outcrop. Seismic reflection facies mapping, documented in Chapter 7, demonstrates continuity of the formation between the outcrop and the well.

Overlying the North Cape Formation in Kiwa-1 are the terrestrial coal-measure deposits of the Kaimiro Formation (King 1988a), indicating a regressive event roughly coincident with the Cretaceous/Tertiary boundary, as at North Tasman-1.

Tane-1. Top Cretaceous in Tane-1 lies at the top of a shallow-marine sandstone at $3492 \mathrm{~m}$ (King 1988a). This sandstone was called the "Island Sandstone" in the well completion report (Shell BP and Todd 1977) and assigned by King to his informal Tahi Group. The unit extends from $3492 \mathrm{~m}$ to $3638 \mathrm{~m}$. As it is a shallow marine, silty sandstone of latest Cretaceous age, the unit is here assigned to the North Cape Formation of the Pakawau Group. This unit has excellent petroleum reservoir properties, with a porosity of over $20 \%$, and a permeability of over $500 \mathrm{mD}$ (Shell BP and Todd 1977). Van der Lingen and Smale (1990, 1992) have investigated the diagenesis of the sandstone, and concluded that the high porosity is due to the preservation of primary porosity, perhaps within a sealed system. Above the Cretaceous/Tertiary boundary in this well are the calcareous silts and muds of the Moa Group.

Underlying the North Cape Formation sands are more than $800 \mathrm{~m}$ of coal-bearing sands and silts from $3638 \mathrm{~m}$ to basement at $4475 \mathrm{~m}$. King (1988a) assigned all these rocks to the undifferentiated Pakawau Group. Seismic reflection mapping shows that the sequence from $3638 \mathrm{~m}$ to $4000 \mathrm{~m}$ is laterally equivalent to rocks of presumed marine origin associated with a transgression originating in the New 
Caledonia Basin to the north. These rocks are also laterally continuous, as shown by seismic refleciton data, with Wainui Member rocks in the Wainui-1 well. The sandy, coal-bearing sequence from $3638 \mathrm{~m}$ to $4000 \mathrm{~m}$ is therefore assigned to the Wainui Member of the North Cape Formation. Below about $3830 \mathrm{~m}$, this unit is sandier and less carbonaceous than above this depth, indicating that the lower portion of the Wainui Member in this well may be better placed in the undifferentiated North Cape Formation.

Below the Wainui Member there is both an increase in the amount of coal and the amount of carbonaceous shale. Based on seismic mapping, stratigraphic position and lithology, the rocks from $4000 \mathrm{~m}$ to basement at $4475 \mathrm{~m}$ are here assigned to the Rakopi Formation of the Pakawau Group.

Wainui-1. Top Cretaceous in Wainui-1A is at approximately $3703 \mathrm{~m}$ (King 1988a). Overlying the Cretaceous sequence are the fine grained marine rocks of the Moa Group. Basement is at $3875 \mathrm{~m}$. From 3703 to $3762 \mathrm{~m}$ is a $60 \mathrm{~m}$ thick sequence of shallow marine siltstones which King (1988a) assigned to his informal Tahi Group. These rocks are here assigned instead to the North Cape Formation of the Pakawau Group. This assignment is based on the sandy-silty nature of the sediments, the lack of significant carbonaceous material, the shallow marine depositional environment and the stratigraphic position of the unit.

From $3762 \mathrm{~m}$ to basement at $3875 \mathrm{~m}$ is a series of sand-dominated coal measures with considerable calcareous cement (Shell BP and Todd 1982a). This sequence is here nominated the type section of the Wainui Member of the North Cape Formation. Seismic facies mapping shows this member to be widespread within the northwest corner of Taranaki Basin (Chapter 7). From lithology and seismic facies mapping these sediments are thought to represent a lower coastal plain environment.

Ariki-1. Top Cretaceous in Ariki-1 is at approximately $4319 \mathrm{~m}$ (King 1988a). Overlying the Cretaceous sequence are fine grained marine rocks of the Moa 
Group. The entire late Cretaceous sequence from $4319 \mathrm{~m}$ to basement at 4762 $\mathrm{m}$ is here assigned to the North Cape Formation of the Pakawau Group. This sequence consists of marine sands and silts at the top, grading downwards into shales. Shell BP and Todd (1984) originally assigned this sequence to the Pakawau Group (marine facies), and King (1988a) assigned it to the informal Tahi Group.

Te Ranga-1. This well location is above the Taranaki Fault overthrust on the extreme eastern edge of the basin. The well penetrated an overthrust basement block before encountering fine-grained Paleogene marine rocks, extending from the base of the basement block at about $2900 \mathrm{~m}$ down to $3667 \mathrm{~m}$. These rocks were referred to in the well completion report (Shell BP and Todd 1986) as the Kaiata Formation, and are assigned in the present study to the Moa Group. An abrupt change in wireline-log character at $3667 \mathrm{~m}$, interpreted by Shell, BP and Todd (1986) as an unconformity, coincides with the top of the Cretaceous sediments.

Immediately below the Cretaceous-Tertiary boundary at $3667 \mathrm{~m}$ is a $50 \mathrm{~m}$ thick grey siltstone of shallow marine origin. Shell BP and Todd (1986) correlated this interval with the uppermost Cretaceous sediments in Ariki-1, and informally named it the Ariki Formation. This correlation with Ariki-1 is accepted here, and the sequence is therefore assigned to the North Cape Formation of the Pakawau Group. The thin nature of the unit, combined with its considerable depth of burial and the poor quality of seismic reflection data in the North Taranaki Graben, have precluded seismic reflection mapping of the unit and therefore a seismic correlation is not possible.

The base of the North Cape Formation in Te Ranga-1 is a major unconformity at $3717 \mathrm{~m}$. From this unconformity to TD at $3882 \mathrm{~m}$ is a sequence of sandstone, coal and carbonaceous shale of marginal marine to terrestrial origin. Shell BP and Todd (1986) assigned these rocks to the informal Taniwha Formation. A Clarence Series (middle Cretaceous) age was given for the Taniwha Formation, 
and confirmed recently by J.I. Raine (pers. com.) These are the oldest sedimentary rocks yet encountered in Taranaki Basin. In the present study the Taniwha Formation is not assigned to a group, and is considered a pre-late Cretaceous unit.

\subsection{Wireline log correlation}

The most common tool available to assist with stratigraphic correlation of subsurface units in petroleum exploration wells is the wireline-log suites collected during drilling. Wireline logs are available for all of the Taranaki Basin wells used in this study. Enclosure 6.2 is a wireline log correlation panel for the late Cretaceous sequence of Taranaki Basin. On this panel the gamma ray, a long-spaced deep resistivity log (ILD or LLD), and a sonic log are illustrated.

The gamma ray (GR) log measures the incidence of radioactive decay in the rock strata intersected by the well. This $\log$ is an indirect lithologic indicator, independent of drilling muds or formation fluids, and generally proportional to the clay content of the formation. In the present study it was found to be a very good correlation tool, especially to show the uniform, massive, clay-poor character of many North Cape Formation sequences (for example see Cook-1 or North Tasman-1 on enclosure 6.2).

Deep resistivity logs measure the resistance of rock strata to a weak electric current discharged by the logging tool. By using a deep resistivity log (LLD, ILD or similar) the resistivity of the rock (including formation fluids) beyond the zone of drilling-fluid invasion into the formation is measured. The homogeneous lithology of portions of the North Cape Formation shows up well on this log as a subdued, slowly varying trace. The interbedded nature of the Puponga and Wainui members, and the Rakopi Formation, is also distinctive. This log is particularly sensitive to sand and shale interbedded sequences. 
Sonic logs measure the interval-transit-time for a high-frequency sound wave to travel though the rock sequence. The record is scaled in units of milliseconds of travel time per foot of formation. Once again, the homogeneous nature of much of the North Cape Formation is in contrast to the interbedded nature of its coal-bearing members and of the Rakopi Formation. The sonic log is particularly sensitive to lithologic and compaction effects and is a good indicator of fine-grained strata and coal beds, which have relatively slow seismic velocities.

The other very commonly used correlation log is the spontaneous potential (SP). The spontaneous potential tool measures the voltage difference between formation rocks in the subsurface and a surface grounding point. This voltage is very dependent on the salinity and ionic capacity of the drilling mud, formation fluids, and rock matrix, as well as on the bimetallic voltages generated by casing, drilling equipment and logging tools. The spontaneous potential log is a very good correlation tool when the conditions affecting it can be carefully controlled or vary only slightly, such as within limited geographic areas. However, where distances between wells are great, or wells are drilled under very different conditions (different operators using different drilling equipment, drilling muds and logging methods), the SP log is of limited use for stratigraphic correlation. For this reason, the SP log is not included in Enclosure 6.2.

\subsection{Chronostratigraphic correlation}

Chronostratigraphic correlation is the classification and correlation of a series of rocks into units on the basis of geologic time indicators, and allows for the age relationships of rock strata to be evaluated. The duration of various sedimentary environments or systems, the rate of sedimentation, and the correlation of significant events in a basin's evolution can be studied by using chronostratigraphic data. The primary input for chronostratigraphic correlation is biostratigraphic data, and for the late Cretaceous sequence of Taranaki Basin the most significant biostratigraphic data comes from the palynology. In 
particular, dinoflagellate determinations are invaluable in ascertaining the extent of marine influence on latest Cretaceous sedimentation, and in providing age control within the North Cape Formation.

To erect a chronostratigraphic system for a series of rock strata, it is necesary to have a system of chronozones (usually paleontologically based) into which observations can be placed with confidence. In the case of the late Cretaceous rocks of Taranaki Basin, three systems of convenience can be utilized. These are the New Zealand geological time scale (the Cretaceous and Cenozoic portion of which was updated by Edwards and others 1988), the New Zealand palynological zonation (Raine 1984, correlated to the New Zealand geological time scale by Edwards and others 1988), and the New Zealand dinoflagellate zonation (Wilson 1984, and updated more recently (for example see Pocknall and others 1989)).

The biostratigraphy of each Cretaceous well section in Taranaki Basin has been reviewed and evaluated with respect to the three systems mentioned above. The specifics of these wells are discussed below, and their correlations are illustrated on Enclosure 6.3. Enclosure 6.3 is a chronostratigraphic diagram for the late Cretaceous rocks of Taranaki Basin. This diagram is plotted with the vertical axis in millions of years, and also shows the various international and New Zealand biostratigraphic correlation zones.

Cook-1. As a part of this study, Wilson (1991a) has examined several samples from the North Cape Formation in Cook-1. Wilson ascertained that dinoflagellates were present throughout the interval, indicating shallow marine deposition. The North Cape Formation was deposited entirely within the Manumiella drugii and Alterbidinium acutulum dinoflagellate zones of Wilson (1984). The boundary between these two zones is at a depth of about $1800 \mathrm{~m}$ (Wilson 1991a). The remainder of the Cook-1 sequence requires miospores for age control. Harris (1970) found all strata below the North Cape sequence 
discussed above to be of Haumurian age. Hence, the Rakopi Formation in Cook-1 is limited to the Haumurian stage.

Outcrop. To establish a Taranaki Basin chronostratigraphic framework it is necesary to obtain some control on three portions of the outcropping Pakawau Basin sequence: the location of the Cretaceous/Tertiary boundary; the age of the North Cape Formation, and the age of the oldest rocks in the late Cretaceous sedimentary sequence. Raine (1989) determined that the Cretaceous/Tertiary boundary was very near the top of the "Puponga Formation". Hence, the sequence below the top of the Puponga Member is considered here to be late Cretaceous.

Palynological examination of samples collected from the North Cape Formation during the present study has been reported by Wilson (1991b). Three North Cape Formation samples, all from the lower portions of the formation, were examined, and all three found to contain dinoflagellates indicating marine deposition. Wilson (1991b) suggests all three samples probably represent the A. acutulum dinoflagellate zone of Wilson (1984). This is consistent with the dinoflagellate zones from the Cook- 1 well.

Raine (1984) reported on the palynological examination of a number of samples from various stratigraphic positions within the outcropping Pakawau Group, and found no evidence for any palynological zone other than PM2. The Rakopi Formation, as known at present, is therefore restricted to zone PM2 (Haumurian).

Cape Farewell-1. This is the deepest well in the Pakawau Basin, and penetrates a sequence stratigraphically lower than any in either Cook-1 or Fresne-1. The original well completion report (Carter and Kintaner 1987) reported rocks as old as Clarence Age (mid Cretaceous) from the lower sequences in the well. More recently, as a part of the present study, J.I. Raine (pers com., see Appendix 2) has revised the palynological biostratigraphy of this well and has concluded that only 
pollen zone PM2 is present. No detailed biostratigraphic study has been conducted on the North Cape Formation within Cape Farewell-1, but the sequence is presumed, because of proximity, to be chronostratigraphically equivalent to the outcrop sequence and to wells Cook-1 and Fresne-1.

Fresne-1. The Cretaceous sequence penetrated by Fresne- 1 is poorly dated and requires further biostratigraphic study. Hayward and Raine (1985) gave palynological evidence that the entire Cretaceous sequence ( $923 \mathrm{~m}$ to TD at 2504 m) is Haumurian. They examined two sets of cuttings from within the North Cape Formation (1230 to $1550 \mathrm{~m})$. One of these samples $(1427 \mathrm{~m})$ contained dinoflagellate cysts, indicating marine conditions of deposition. The species list of Hayward and Raine (1985) shows this sample to include the index species Alterbia acutula, used by Wilson (1984) to indicate the A. acutulum dinoflagellate zone. This zonation for the North Cape Formation is in agreement with the Cook-1 data. Fresne- 1 only penetrated the upper $50 \mathrm{~m}$ of the Rakopi Formation, an interval determined by Hayward and Raine (1985) to be Haumurian (Pollen Zone PM2).

North Tasman-1. Only the North Cape Formation (including a possible Wainui Member equivalent), is encountered in this well (from 2273 to $2669 \mathrm{~m}$ ). Several dinoflagellate species were recorded from this sequence by Hayward and Raine (1978), and used to assign a Cretaceous age to the interval. The Hayward and Raine species lists indicate the presence of Isabelidinium cretaceum in the interval $2286 \mathrm{~m}$ to $2426 \mathrm{~m}$. Comparison with the index species of Wilson (1984) suggests this interval is most likely to be within the M. druggi Zone.

Tahi-1. The North Cape Formation in Tahi-1 underlies a Miocene unconformity where the upper portion of the formation has been removed. Pocknall and others (1989) found the interval here assigned to the North Cape Formation to be entirely within the A. acutulum Zone. The presence of dinoflagellates of the A. acutulum Zone from within the upper part of the Rakopi Formation at 1477 $m$ indicates that the top of the Rakopi Formation is slightly younger here than 
elsewhere in the basin, and that some marine influence was experienced prior to the cessation of Rakopi Formation sedimentation.

Kupe South-4. Pocknall and others (1989) present evidence that the entire Cretaceous sequence penetrated by this well ( $3500 \mathrm{~m}$ to TD at $3800 \mathrm{~m}$ ) is within the $M$. druggii dinoflagellate zone. Thus this well represents only the last one million years or less of the Cretaceous Epoch.

Maui-4. The late Cretaceous sequence in Maui-4 well is very poorly studied. Some palynological work was conducted on well samples at the time of drilling (Shell BP and Todd 1970), and reviewed by Raine (1984). Raine found that the upper portion of the late Cretaceous in Maui-4 was likely deposited in a marine environment, and that the lowestmost samples from the coal measures (Rakopi Formation) were within zone PM2.

Kiwa-1. The Kiwa-1 well has a fairly thin latest Cretaceous sequence, from 3638 $\mathrm{m}$ to basement at $3839 \mathrm{~m}$. The palynology of this sequence was investigated in detail by Mildenhall and others (1981), and numerous dinoflagellates were observed. This work predates the dinaflagellate zonation of Wilson (1984). The species lists contained in Mildenhall and others, when compared with the species listed in Wilson (1984), indicate that the entire late Cretaceous sequence in Kiwa-1 is most likely within the $M$. druggii and possibly the A. acutulum zones. In particular, the sample from $3688 \mathrm{~m}$ is very diagnostic of $M$. druggii zonation, with Palaeocystodinium cf australinum, Isobelidinium druggii and $I$. cf zeelandicum identified.

Tane-1. Wilson (1988) studied the dinoflagellate stratigraphy of Tane-1 in an attempt to locate the Cretaceous/Tertiary boundary. He presents definitive evidence for the presence of the Trithyrodinium evittii dinoflagellate zone in a sample from $3488 \mathrm{~m}$, and of the $M$. druggii Zone in samples between $3500 \mathrm{~m}$ and $3517 \mathrm{~m}$. Previously, Wilson (1985) had identified the lower $M$. druggii Zone at $3615 \mathrm{~m}$, and the A. acutulum (or uppermost Odontochitina porifera) Zone at 3634 
m. The Wainui Member of the North Cape Formation extends from $3638 \mathrm{~m}$ to $4000 \mathrm{~m}$, some distance below these observations. It therefore seems likely that much of this interval falls within the O. porifera Zone. Mildenhall and Raine (1977) showed that the remainder of the late Cretaceous sequence down to basement (4475 m) is Mata Series, probably Haumurian, although Piripauan is possible for the lowest samples.

Wainui-1. Mildenhall and Wilson (1982) studied the palynology of the Wainui-1 well, and reported the late Cretaceous sequence had fairly rich dinoflagellate assemblages. Although not assigned zones under the Wilson (1984) dinoflagellate zonation, the species lists presented in Mildenhall and Wilson (1982) allow for zone assignments in the well. The North Cape Formation interval (3703 m to $3762 \mathrm{~m}$ ) contains the index fossil Isabelidinium druggii, as well as I. seelandicum and Palaeocystodium australinum, indicating the $M$. druggii Zone. Alterbia acutula first appears at $3766 \mathrm{~m}$, at the top of the Wainui Member of the North Cape Formation, indicating the A. acutulum Zone. At $3868 \mathrm{~m}$, a few metres above basement at $3875 \mathrm{~m}$, is the appearance of Odontochitina operculata, indicating the lowest portions of this hole may be in the $O$. porifera dinoflagellate zone.

Ariki-1. The palynology of Ariki-1 was reported by Crosbie and Clowes (1984), who stated that the entire late Cretaceous sequence in the well (4319 $\mathrm{m}$ to basement at $4762 \mathrm{~m}$ ) was Haumurian, but did not further subdivide the sequence. This entire interval is here assigned to the North Cape Formation. The dinoflagellate species lists presented by Crosbie and Clowes (1984) can be used to attach preliminary zones to the well sequence. In particular the presence of Alterbia acutula in samples from $4379 \mathrm{~m}$ to possibly $4645 \mathrm{~m}$ indicates an $A$. acutulum Zone for this interval. The $O$. porifera dinaflagellate zone is indicated below this by the appearance of Odontochitina spinosa.

Te Ranga-1. The very thin late Cretaceous sequence ( $3667 \mathrm{~m}$ to $3717 \mathrm{~m}$ ) has been difficult to date (Mildenhall and others 1986a, 1986b). A latest Haumurian 
age (post-O. porifera) has been speculated by Mildenhall and others (1986b) based on the absence on Odontochitina in a side wall core from $3710 \mathrm{~m}$. A Ngaterian age was preferred by Mildenhall and others (1986a, 1986b) for the Taniwha Formation interval (3717 m to TD) in Te Ranga-1, based on abundant, but poorly preserved spores and pollen. This age has recently been confirmed by J.I. Raine (pers. com.).

A few generalizations made from the chonostratigraphic evidence detailed above are presented in Enclosure 6.3. The entire late Cretaceous sequence in Taranaki Basin appears to be confined to the Haumurian Stage. With the exception of a few transitional sequences, dinoflagellates are confined to the North Cape Formation and its Puponga and Wainui members (and equivalents). This appears to confirm that the Rakopi Formation is a dominantly terrestrial unit, and the marine influence (transgression) is confined to the North Cape Formation.

Throughout most of the basin, the North Cape Formation represents only the very latest Cretaceous. In all but the northwesternmost wells, the North Cape Formation is constrained to the dinoflagellate zones $M$. druggii and A. acutulum, representing about the last 3 million years of the Cretaceous. In wells Tane-1, Wainui-1 and Ariki-1 the North Cape Formation extends down into the $O$. porifera Zone. This indicates that the regional transgression which imposed marine and marginal marine conditions on Taranaki Basin during the latest Cretaceous was recorded first in these northern wells, and hence may have spread from north to south. The presence of a thick A. acutulum Zone as far south as Cook- 1 indicates that the transgression must have inundated the basin very near the $O$. porifera to $A$. acutulum zone boundary. The transgression must have propagated southward fairly rapidly, imposing marine conditions over most of the basin within a period of a few million years.

One consequence of the fairly short time span (3 to 4 million years) for the deposition of the North Cape Formation is the high sedimentation rates required. 
The North Cape Formation, including its members and equivalents, is locally in excess of $1200 \mathrm{~m}$ thick in some south Taranaki Basin depocentres, where the duration of deposition is confined to less than 3 million years. This indicates a sedimentation rate of over $400 \mathrm{~m} / \mathrm{Ma}$. The Rakopi Formation rarely exceeds $2000 \mathrm{~m}$ thick in the same depocentres, and may have had a duration of deposition in excess of 10 million years, indicating a sedimentation rate of $200 \mathrm{~m} / \mathrm{Ma}$. These sedimentation rates are not corrected for the effects of compaction, but at the burial depth of most late Cretaceous sequences in Taranaki Basin (generally greater than $3 \mathrm{~km}$, see Enclosure A.3), these sequences will have compacted to about 60 to $80 \%$ of their original thickness (Hayward 1987), depending on lithology.

\subsection{Geochemical correlation}

Another type of data available to assist in the deposition and correlation of a series of strata is the geochemistry of the rocks. The geochemical indicator most commonly available for petroleum exploration wells is total organic carbon (TOC). The TOC of a rock sample is the percentage, by weight, of the sample which is composed of elemental carbon held within organic molecules. The TOC of drill cuttings has been determined for many of the wells which have penetrated the late Cretaceous sequence in Taranaki.

Often TOC is used to screen samples prior to running more sophisticated geochemical analytical techniques, such as Rock-Eval Pyrolysis. Because Rock-Eval Pyrolysis is generally only conducted on samples with TOC values in excess of $0.5 \%$, the record of TOC measurements is much more complete than that of pyrolysis measurements, especially where organic richness is low. This completeness of record is the main reason for choosing TOC as a geochemical correlator for this study. 
Enclosure 6.4 shows the correlation of all wells which have had sufficient TOC measurements conducted to construct a profile of TOC versus depth within the late Cretaceous sequence. Most of these measurements were conducted by either Analabs (1984) or Robertson Research (1984) during the course of basin-wide source rock evaluation programmes. The TOC measurements are plotted against a three-cycle logarithmic scale, in order to emphasizes low TOC values. This is important, as many TOC values are less than $1 \%$, and only a very few are greater that $50 \%$. Only seven wells are displayed on Enclosure 6.4. Other wells have had a few TOC measurements conducted, but not enough to construct a profile. Ariki-1 has had no TOC measurements from within the late Cretaceous sequence, but other geochemical data indicate the organic content of the North Cape Formation in Ariki-1 is likely to be very low (Shell, BP and Todd 1984).

The most outstanding feature of Enclosure 6.4 is the low incidence of carbonaceous material (TOC) in the North Cape Formation, excluding its Puponga and Wainui members. The North Cape Formation contains $0.5 \%$ or less TOC throughout most of the basin, with a possible tendency to slightly higher values in more distal situations (compare Fresne-1 with Kiwa-1 or Tane-1). The Puponga and Wainui members are more highly variable and more highly carbonaceous, with most values over $1 \%$, and up to $50 \%$ TOC.

The Rakopi Formation is also highly variable, and highly carbonaceous. TOC values range from less than $0.5 \%$ to over $50 \%$, with values in excess of $5 \%$ very common. The few values from cuttings samples from below the basement contact, such as in North Tasman-1 and Tane-1, give an indication of the possible amount of scatter and contamination in these data. Downhole contamination from cavings is the most likely cause for these $0.5 \%$ to $2 \%$ TOC values, and must be kept in mind when evaluating other data from higher in the hole.

The Paleogene sequence overlying the North Cape Formation shows a similar TOC story to the late Cretaceous sequence, with terrestrial sediments being more carbonaceous, and more variable, than marine sediments. The Kapuni Group 
sequences tend to exhibit TOC values in excess of $1 \%$, and up to $50 \%$, while the Moa Group sequences rarely exceed $1 \%$ TOC.

One problem with the application of TOC measurements to characterize large volumes of rock is the bias introduced by sampling procedures. Often the most organically rich intervals within a sequence are sampled for TOC analysis. The TOC values may be indicative not of the organic content of the unit as whole, but of organic-rich intervals within the unit. This bias is not of concern where the TOC values are low enough to discount any significant petroleum source-rock potential, but may be a problem where source rocks are indicated, especially if volumetric estimates of hydrocarbon yield are being considered.

TOC is only an approximate indicator of the ability of a sequence to generate hydrocarbons, and no firm guidelines are available to separate "good" source rocks from "poor" source rocks using TOC alone. A "high" TOC value from a rock sequence indicates that the rock may be able to source petroleum provided the thermodynamic conditions are appropriate for the particular type of organic material within the rock. On the other hand, a rock with "low" TOC is highly unlikely to be able to produce petroleum under any circumstances. Thus whereas TOC alone cannot determine what rocks can, or have, generated petroleum, these data can indicate what rocks cannot be considered as potential source rocks. A generally accepted threshold, below which source potential is considered negligible to slight, is $1.0 \%$ (Waples 1985). Above $1.0 \%$ potential is considered modest, and above $2.0 \%$ potential is considered good.

Table 6.1 summarizes the results of the large number of publicly available TOC measurements from late Cretaceous rocks in the basin. Note that both the upper late-Cretaceous coal measures (Puponga and Wainui members of the North Cape Formation) and the lower late-Cretaceous coal measures (Rakopi Formation) have very high TOC averages. The variability in these rocks, as indicated by the standard deviation, is also high. In contrast, the upper late-Cretaceous marine 
rocks (North Cape Formation) have very low TOC values, with an average of only $0.4 \%$ and a standard deviation of $0.6 \%$.

TABLE 6.1 Total Organic-Carbon data for late Cretaceous sediments

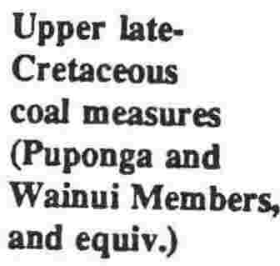

Average

Standard deviation

Number wells

Number samples

Maximum value

Minimum value and equiv.)

\author{
Upper late- \\ Cretaceous \\ marine clastics \\ (North Cape \\ Formation)
}

Lower late-

Cretaceous coal measures

(Rakopi Formation)

$\begin{array}{llll}\text { Average } & 10 \% & 0.4 \% & 9 \% \\ \text { Standard deviation } & 14 \% & 0.6 \% & 11 \% \\ \text { Number wells } & 5 & 7 & 5 \\ \text { Number samples } & 80 & 121 & 120 \\ \text { Maximum value } & 59.3 \% & 3.9 \% & 52.1 \% \\ \text { Minimum value } & 0.26 \% & 0.03 \% & 0.03 \%\end{array}$

Throughout the central portion of Taranaki Basin, including in the deep parts of the Taranaki Graben, most of the upper late-Cretaceous unit is probably marinedeposited sandstone, as at Maui-4. The organic-rich Rakopi Formation (lower late-Cretaceous) coal measures are separated from the organic-rich Kapuni Group (early Tertiary) coal measures by 500 to $1500 \mathrm{~m}$ of these organic-poor marine transgressive sediments. Hence, when considering the source rock potential of the late Cretaceous Pakawau Group within the Taranaki Graben, the dominant unit is the Rakopi Formation.

Upper late-Cretaceous coal measures are much more extensive on the Western Platform (see Chapter 7). These coastal-plain sediments cover most of the Western Platform as a veneer, up to $500 \mathrm{~m}$ thick. Within the central portions of the basin, laterally discontinuous organic-rich coastal plain deposits are also present, but the volume of these deposits is small (see Chapter 7). 
One major unresolved problem in our understanding of the source of hydrocarbons in Taranaki Basin is the burial depth required for generation and expulsion in the basin. Many authors have indicated that the depth of burial in Taranaki Basin is greater than that generally required for hydrocarbon generation. For example Cook $(1987,1988)$ suggests a depth greater than $5.5 \mathrm{~km}$ for generation in Taranaki Basin. Johnston and others (1990) give depth of $5 \mathrm{~km}$ for Pakawau Group sediments, and $6 \mathrm{~km}$ for Kapuni Group sediments to be the source of Taranaki Basin's oil and gas. Sykes and others (in press) suggest that while hydrocarbons may be generated in Taranaki Basin at depths of about $3 \mathrm{~km}$, expulsion of those hydrocarbons from the source rock sequences may require burial to about $5 \mathrm{~km}$.

If these inferred depths to generation and expulsion are correct, then Kapuni Group sediments, which are buried deeper than $5.5 \mathrm{~km}$ only in very limited areas (see Enclosure A.1), are not important in the generation of hydrocarbons. Even the upper late-Cretaceous coal measures of the Wainui and Puponga members, and equivalents, are rarely buried to depths considered great enough to generate and expel hydrocarbons by the authors referenced above (see Enclosure A.3). For example the Western Platform, discussed in the previous section, does not include regions where North Cape Formation coal measures are buried deeply enough to constitute mature source rocks using a burial depth of $5 \mathrm{~km}$.

Only the Rakopi Formation coal measures are routinely buried deeper than $5 \mathrm{~km}$ (Enclosure 5.4). Given the distribution of this sequence, underlying or adjacent to the known hydrocarbon accumulations, and its substantial thickness and organic-rich nature, the Rakopi Formation seems to contain the most probable source rocks for Taranaki Basin's hydrocarbons. 


\subsection{Conclusions}

In the study of subsurface stratigraphy, there are several methods available to assist with correlation of sequences of similar strata. For Taranaki Basin, the most readily correlatable geologic properties are lithology, wireline log signature, biostratigraphic age, carbonaceous content, and seismic reflection signature. For the late Cretaceous sequence these various methods of correlation are in remarkable agreement.

Chapter 5 discussed the subdivision of the late Cretaceous sequence into two distinct units which could be mapped using seismic reflection data. These two units were referred to as the "lower late-Cretaceous" and "upper late-Cretaceous" sequences, separated a regional "mid late-Cretaceous" horizon.

The lower late-Cretaceous seismic unit almost everywhere corresponds with the Rakopi Formation of Haumurian age. The one exception to this occurs in the extreme northeast corner of the study area, where strata of the middle Cretaceous Taniwha Formation are included within the lower seismic unit. These rocks are believed to be confined to the Northern Taranaki Graben, along the footwall of the Taranaki Fault. The Rakopi Formation consists of terrestrial, carbonaceous sediments deposited in early-rift subbasins.

The upper late-Cretaceous seismic unit corresponds to the North Cape Formation and its members. This unit is more widespread, and represents a latest Cretaceous transgressive event. The marine facies of this transgressive system tend to lack carbonaceous sediments, while the lateraly equivalent coastal plain and terrestrial sediments (Puponga and Wainui members, and equivalents) are rich in carbonaceous material. The marine facies are, however, quite sandy and have potential as petroleum reservoirs.

The hydrocarbon source rock potential of the Late Cretaceous is concentrated in the thick, coal-bearing Rakopi Formation and the thinner, more discontinuous 
Puponga and Wainui members of the North Cape Formation. The marine strata of the North Cape Formation are so deficient in carbonaceous material as to make them unlikely source beds for hydrocarbon generation.

The horizon separating the lower and upper seismic units is the basal transgressive surface of the North Cape Formation. This horizon is oldest in the northernmost wells and may be youngest in the Manaia Basin in the south, indicating a southward direction of transgression. This southward propagation of the transgression was fairly rapid, however, requiring at most only a few million years to inundate the entire system of rift-related subbasins. This relative rise in sea level was probably due to the post-rift cooling and subsidence of the region. While eustatic effects may have contributed to the transgression, a sea-level rise alone would not be of sufficient magnitude to result in the deposition of marine sequences with a compacted thickness of up to $1500 \mathrm{~m}$, the maximum thickness of the North Cape Formation.

The line of maximum onlap of the top Cretaceous seismic reflection horizon, in the southern portions of the basin, records the maximum extent of the late Cretaceous transgression. In the Paleocene a regression allowed the deposition of thick sequences of terrestrial strata over the shallow-marine transgressive sediments of the latest Cretaceous across much of the basin. This regressive event is responsible for the Kapuni Group (including the Farewell Formation) sediments exposed in outcrop and encountered in wells Cook-1, Fresne-1, North Tasman-1, Kupe South-4, Maui-4 and Kiwa-1. The base of this regression is the geologic horizon which separates the Pakawau Group and Kapuni Group sequences.

In contrast with the southern portions of the basin, the northerly wells experienced continued marine conditions from the Cretaceous into the Paleocene, resulting in the deposition of the Paleogene Moa Group. This south to north contrast may be due to a northward tilting of the region about an east-west axis near Kiwa-1, or may be the result of a rapid increase in sediment supply from the 
south, or a combination. A northward tilting would be consistent with the southward propagation of the marine transgression which occured a few million years earlier, during the late Cretaceous. Careful geohistory analysis might serve to quantify the relative contributions of tectonic and sediment supply parameters.

\subsection{References}

Analabs 1984: Petroleum geochemistry of the Taranaki Basin. Unpublished open-file petroleum report 1013, filed at DSIR Geology and Geophysics, Lower Hutt.

Bishop, D.G. 1971: Sheet S1 and S3 - Farewell and Collingwood. Geological map of New Zealand 1:63,360. Wellington, New Zealand. Department of Scientific and Industrial Research.

Carter, M.; Kintaner, E.R.L. 1987: Cape Farewell-1, well completion report PPL 38119. Unpublished open-file petroleum report 1234, filed at DSIR Geology and Geophysics, Lower Hutt.

Cook, R.A. 1987: The geology and geochemistry of the crude oils and source rocks of western New Zealand, PhD thesis, Victoria University of Wellington.

Cook, R.A. 1988: Interpretation of the geochemistry of oils of Taranaki and West Coast regions, western New Zealand. Energy Exploration and Exploitation 6(3): 201-212.

Crosbie, Y.M.; Clowes, C.D. 1984: Palynology of Ariki-1 offshore well, 3699 4760m. New Zealand Geological Survey report PAL 79. 
Edwards, A.R.; Hornibrook, N.deB.; Raine, J.I.; Scott, G.H.; Stevens, G.R.; Strong, C.P.; Wilson, G.J. 1988: A New Zealand Cretaceous - Cenozoic geological time scale. New Zealand Geological Survey Record 35: 135-149.

Harris, W.F. 1970: Report of samples examined for pollen and spores, Cook-1. Unpublished note on file with DSIR Geology and Geophysics, Lower Hutt

Hayward, B.W. 1987: Paleobathymetry and structural and tectonic history of Cenozoic drillhole sequences in Taranaki Basin. New Zealand Geological Survey report PAL 122.

Hayward, B.W.; Raine, J.I. 1978: Biostratigraphy of North Tasman-1 offshore well. New Zealand Geological Survey report PAL 30.

Hayward, B.W.; Raine, J.I. 1985: Biostratigraphy of Fresne-1 offshore well, near Cape Farewell. New Zealand Geological Survey report PAL 101.

Hedburg, H.D. (ed.) 1976: International stratigraphic guide. John Willey and Sons, Inc., New York: 200p.

Johnston, J.H.: Collier, R.J.; Collen, J.D. 1990: What is the source of Taranaki Basin oils? Geochemical biomarkers suggest it is the very deep coals and shales. In: Ministry of Commerce (1990), 1989 New Zealand Oil Exploration Conference Proceedings: 288-296.

King, P.R. 1988a: Well summary sheets, offshore Taranaki. New Zealand Geological Survey report G-127.

King, P.R. 1988b: Well summary sheets, onshore Taranaki. New Zealand Geological Survey report G-125. 
King, P.R. 1990: Polyphase evolution of the Taranaki Basin, New Zealand: changes in sedimentary and structural style. In: Ministry of Commerce (1990), 1989 New Zealand Oil Exploration Conference Proceedings: 134-150.

King, P.R.; Thrasher, G.P. in press: Post-Eocene development of the Taranaki Basin, New Zealand: convergent overprint of a passive margin. American Association of Petroleum Geologists, memoir 53, chapter 11.

Mildenhall, D.C.; Pocknall, D.T.; Wilson G.J. 1981: Palynology of Kiwa-1 offshore well, 3065m - 3858m. New Zealand Geological Survey report PAL 44.

Mildenhall, D.C.; Raine, J.I. 1977: Report on palynological samples from Shell BP Todd Tane-1 well: 3488m-4420m. New Zealand Geological Survey report PAL 14 .

Mildenhall, D.C.; Wilson, C.J. 1982: Palynology of Wainui-1 offshore well, 3000m - 3894m. New Zealand Geological Survey report PAL 50.

Mildenhall, D.C.; Wilson, G.J.; Scott, G.H. 1986a: Biostratigraphy of Te Ranga-1 offshore well, South Auckland. New Zealand Geological Survey report PAL 116.

Mildenhall, D.C.; Wilson, G.J.; Scott, G.H. 1986b: Supplementary biostratigraphy of Te Ranga-1 offshore well, South Auckland. New Zealand Geological Survey report PAL 119.

New Zealand Aquitaine Petroleum Ltd. 1976: Well completion report - Fresne-1. Unpublished open-file petroleum report 674, filed at DSIR Geology and Geophysics, Lower Hutt.

New Zealand Aquitaine Petroleum Ltd. 1979: Well completion report North Tasman-1 PPL38041 New Zealand. Unpublished open-file petroleum report 736, filed at DSIR Geology and Geophysics, Lower Hutt. 
Palmer, J.A. 1985: Pre-Miocene lithostratigraphy of Taranaki Basin, New Zealand. New Zealand Journal of Geology and Geophysics, Vol. 28: 197-216.

Petroleum Corporation of New Zealand 1984: Tahi-1 well completion report. Unpublished open-file petroleum report 736, filed at DSIR Geology and Geophysics, Lower Hutt.

Pocknall, D.T.; Strong, C.P.; Wilson, G.J. 1989: Biostratigraphy of Kupe South-4, offshore petroleum exploration well, South Taranaki Bight. New Zealand Geological Survey report PAL 144.

Raine, J.I. 1984: Outline of a palynological zonation of Cretaceous to Paleogene terrestrial sediments in West Coast Region, South Island, New Zealand. New Zealand Geological Survey report 109: 82p.

Raine, J.I. 1989: Palynology of outcrop, upper Pakawau Group, northwest Nelson, New Zealand. New Zealand Geological Survey report PAL 148.

Robertson Research 1984: Petroleum geochemistry evaluation of the Taranaki Basin, New Zealand. Unpublished open-file petroleum report 1022, filed at DSIR Geology and Geophysics, Lower Hutt.

Shell BP and Todd 1970: Maui-4 (023/01). Unpublished open-file petroleum report 543, filed at DSIR Geology and Geophysics, Lower Hutt.

Shell BP and Todd 1977: Well resume - Tane-1 (offshore) PPL 38007. Unpublished open-file petroleum report 698, filed at DSIR Geology and Geophysics, Lower Hutt.

Shell BP and Todd 1982a: Well resume. Wainui-1. Unpublished open-file petroleum report 869, filed at DSIR Geology and Geophysics, Lower Hutt. 
Shell BP and Todd 1982b: Well resume - Kiwa-1. Unpublished open-file petroleum report 880, filed at DSIR Geology and Geophysics, Lower Hutt.

Shell BP and Todd 1984: Completion report, Ariki-1 well. Unpublished open-file petroleum report 1038, filed at DSIR Geology and Geophysics, Lower Hutt.

Shell BP and Todd 1986: Well resume - Te Ranga-1 PPL 38107 Taranaki. Unpublished open-file petroleum report 1197, filed at DSIR Geology and Geophysics, Lower Hutt.

Suggate, R.P. 1956: Puponga Coalfield. New Zealand journal of science and technology B37(5): 539-559.

Sykes, R.; Suggate, R.P.; King, P.R. in press: Timing and depth of maturation in southern Taranaki Basin from reflectance and $\operatorname{rank}(\mathrm{S})$. In: Ministry of Commerce, 1991 New Zealand Oil Exploration Conference Proceedings.

TCPL Rsources Ltd. 1989: Well completion report Kupe South-4 PP1 38116. Unpublished open-file petroleum report 1483, filed at DSIR Geology and Geophysics, Lower Hutt.

Thrasher, G.P.; Cahill, J.P. 1990: Subsurface maps of the Taranaki Basin region, New Zealand. New Zealand Geological Survey report G-142 (copy in Appendix 1).

van der Lingen, G.J.; Smale, D. 1990: Porosity evaluation of an upper Cretaceous marine sandstone, Tane-1 offshore oil exploration well, Taranaki Basin, New Zealand. In: Ministry of Commerce (1990), 1989 New Zealand Oil Exploration Conference Proceedings: 208-213. 
van der Lingen, G.J.; Smale, D. 1992: High primary porosity preserved in deep (3.5 km) upper Cretaceous marine sandstone, offshore Taranaki Basin, New Zealand. New Zealand Geological Survey record 44: 27-35.

Waples, D.W. 1985: Geochemistry in Petroleum Exploration. International Human Resources Development Corporation, Boston: 232p.

Wilson, G.J. 1984: New Zealand late Jurassic to Eocene dinoflagellate biostratigraphy - a summary. Newsletters on stratigraphy 13: 104-117.

Wilson, G.J. 1985: Dinoflagellate biostratigraphy across Cretaceous-Tertiary boundary, Tane-1 well: 3488-3778m. In: Hayward, B.W. 1985: Foraminiferal biostratigraphy of Tane-1 offshore well, west Taranaki. New Zealand Geological Survey report PAL 100.

Wilson, G.J. 1988: Further notes on the palynology of the Cretaceous-Tertiary boundary, Tane-1 offshore well. Unpublished report GJW 181/88 on file with DSIR Geology and Geophysics, Lower Hutt (copy in Appendix 2).

Wilson, G.J. 1991a: Marine palynostratigraphy of New Zealand Aquitaine Petroleum Ltd. Cook-1 well, Southern Taranaki Basin, 4300'-8730'. Unpublished report GJW 217/91 on file with DSIR Geology and Geophysics, Lower Hutt (copy in Appendix 2).

Wilson, G.J. 1991b: Marine palynostratigraphy of the Pakawau Group, Northwest Nelson. Unpublished report GJW 218/91 on file with DSIR Geology and Geophysics, Lower Hutt. 
CHAPTER 7: SEISMIC FACIES MAPPING OF LATE CRETACEOUS SEQUENCES, TARANAKI BASIN

\subsection{Chapter abstract}

The sedimentary environments of the Taranaki Rift can be assessed using seismic facies mapping. The characteristics of seismic reflection signatures, such as the amplitude, lateral continuity and shape of reflectors, allow seismic reflection units to be qualitatively described and mapped. When these are tied to geologic units and facies, using exploration well and outcrop data, maps of these facies can be constructed.

In Taranaki Basin, the seismic facies character of the Rakopi Formation is consistent everywhere with terrestrial, coal-measure sedimentation. During Rakopi Formation sedimentation, the Taranaki Rift consisted of a series of separate subbasins, probably with through-going drainage, which accommodated locally-derived clastic and organic sediments.

The seismic facies signatures of the overlying North Cape Formation are much more complex. Several seismic facies have been identified, including marine clastic deposits, lower coastal plain deposits (Wainui and Puponga members), fan-delta deposits (Fresne Conglomerate Member) and tidal-channel deposits.

Maps of these facies, made for two times during North Cape Formation sedimentation, show the Taranaki Rift to be a major marine inlet. The late Cretaceous transgression flooded the rift subbasins to their southern limits, and coastal and coastal-plain sediments were deposited around the shores of this inlet.

Seismic facies analysis also reveals the record of late Cretaceous eustatic fluctuations. Low sea level stands are postulated at about 71 and $68 \mathrm{Ma}$ and high sea level stands at about 70 and $67 \mathrm{Ma}$. 


\subsection{Seismic facies mapping}

Information of stratigraphic significance, such as the lithology and depositional environment of a stratigraphic sequence, can be ascertained by careful examination of seismic reflection profiles. This process of seismic facies analysis consists of qualitative assessment of the probable geologic parameters of a seismic sequence by observation of the amplitude, frequency, lateral continuity and lateral shape of reflection events from within the unit. Geologic significance is assigned to particular seismic reflection signatures by correlating those signatures with geologic data obtained from wells or outcrop sections of the units being investigated.

Seismic facies analysis has been a tool of seismic interpreters for over a decade, since being described in detail by Sangree and Widmier (1979). The Shell Oil Company (1987) analysed the sedimentary fill of Taranaki Basin using these concepts, but unfortunately they considered all of the late Cretaceous to be only one seismic sequence (their sequence 8 ), which they correlated with non-marine rocks. This oversimplification resulted from inadequate use of well control, poor dating of well sequences, and use of a very limited selection of seismic profiles. The Shell Oil Company paleogeographic maps show the Taranaki Rift to be entirely terrestrial until the Paleocene, when a very limited area of marine sedimentation encroached in the northwest corner (north of Tane-1).

Seismic reflection profiles interpreted for the present study of the late Cretaceous sedimentary sequence in Taranaki Basin demonstrate several major seismic signatures. These signatures are discussed in detail below, in sections dealing with each of the major late Cretaceous seismic units. Many of the Taranaki Basin seismic facies signatures are very similar to the ideal signatures discussed by Sangree and Widmier (1979), and in their most basic form they allow for the late Cretaceous sedimentary sequence to be differentiated into terrestrial, nearshore and marine components on seismic profiles. Translation of these 
environments from profile view to maps can portray the paleogeography of the region during deposition of the major sedimentary units.

\subsection{Lower late-Cretaceous seismic unit}

Chapter 5 contained an interpretation of a seismic reflection horizon identified as the contact between the Rakopi Formation and the overlying North Cape Formation. This mid-late Cretaceous horizon allows the late Cretaceous syn-rift sequence to be subdivided into two units: the lower unit consists of pre-rift and early-rift rocks of the Taniwha and Rakopi formations, and the upper unit consists of the transgressive rocks of the North Cape Formation and its constituent members.

Figure 7.1 is a simplified isopach map of the lower late-Cretaceous sedimentary unit, which portrays the earliest history of Taranaki Basin. The basin first formed as a series of fault-angle depressions on the downthrown side of normal faults. These depressions are filled with a sedimentary sequence whose seismic reflection signature is that of high-amplitude, hummocky, laterally-discontinuous reflectors. Figures 4.14, 5.2 and 5.4 illustrate this seismic reflection signature, from different portions of the basin. This signature can be tied to the exploration wells Cook-1, Maui-4, Tahi-1 and Tane-1, where the equivalent geologic sequence consists of terrestrially deposited, bedded coal-measure strata of the Rakopi Formation.

Sangree and Widmier (1979) recognize a very similar seismic facies, which they describe as having low-continuity reflections with highly variable frequency and amplitude characteristics. They interpreted the depositional facies associated with this reflection signature as being dominantly non-marine clastics, deposited by fluvial or marginal-marine processes. 


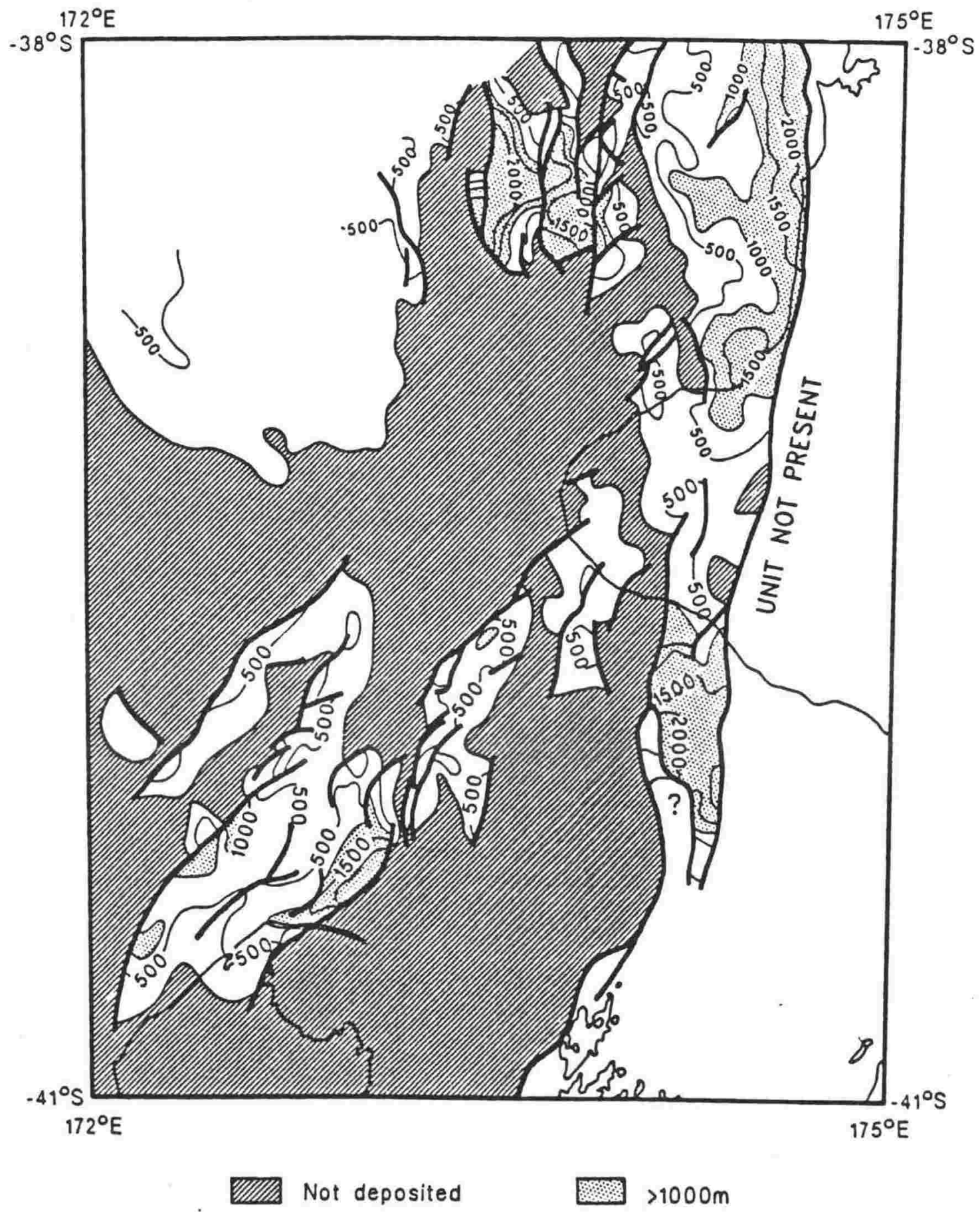

Figure 7.1 Isopach map of lower late-Cretaceous sediments (Rakopi and Taniwha Formations), Taranaki Basin. Simplified from Enclosure 5.2. 
The Otimataura Conglomerate Member of the Rakopi Formation, known only in the Pakawau Region, cannot be distinguished on seismic reflection profiles. This member is not believed to be laterally extensive, and Cape Farewell-1 is the only petroleum exploration which has penetrated the unit. Cape Farewell-1 is in an area of very poor data quality at the depth of the Otimatuara Congolmerate, and the unit does not display a reflection signature distinctively different from the undifferentiated Rakopi Formation. Numerous small conglomeratic fans probably existed throughout the deposition of the Rakopi Formation, along the active fault scarps which controlled the subbasins, but these cannot be tied to a unique seismic reflection character, perhaps due to their small size, present depth of burial, and similarity to some of the diverse sedimentary environments which are represented within the undifferentiated Rakopi Formation.

Exceptions to the generalization that the lower late-Cretaceous seismic reflection unit consists of high-amplitude, hummocky, discontinuous reflectors occur along the eastern edge of the basin. The most significant exception is the rocks of the Taniwha Formation, penetrated only in the Te Ranga- 1 well. The seismic signature of these rocks may have more lateral reflector continuity than the subsequent late-Cretaceous coal-bearing rocks in the basin. Figure 2.6 illustrates the seismic reflection signature of the Taniwha Formation. Shell BP and Todd (1986) suggest that the formation was deposited in a deltaic setting, and the greater lateral continuity of seismic reflectors may be related to the marine influence on the deposition of these rocks.

The Taniwha Formation is probably only present in a depression in the northeast corner of the basin. The possible extent of these rocks, based on the seismic signature and the presumed structural control on their deposition (as indicated by isopach trends), is illustrated in Figure 7.2.

The other possible exception to the seismic-reflection recognition criteria for the lower late-Cretaceous seismic unit lies to the south of the presumed extent of the Taniwha Formation, under the Taranaki Peninsula. In this region, seismic 


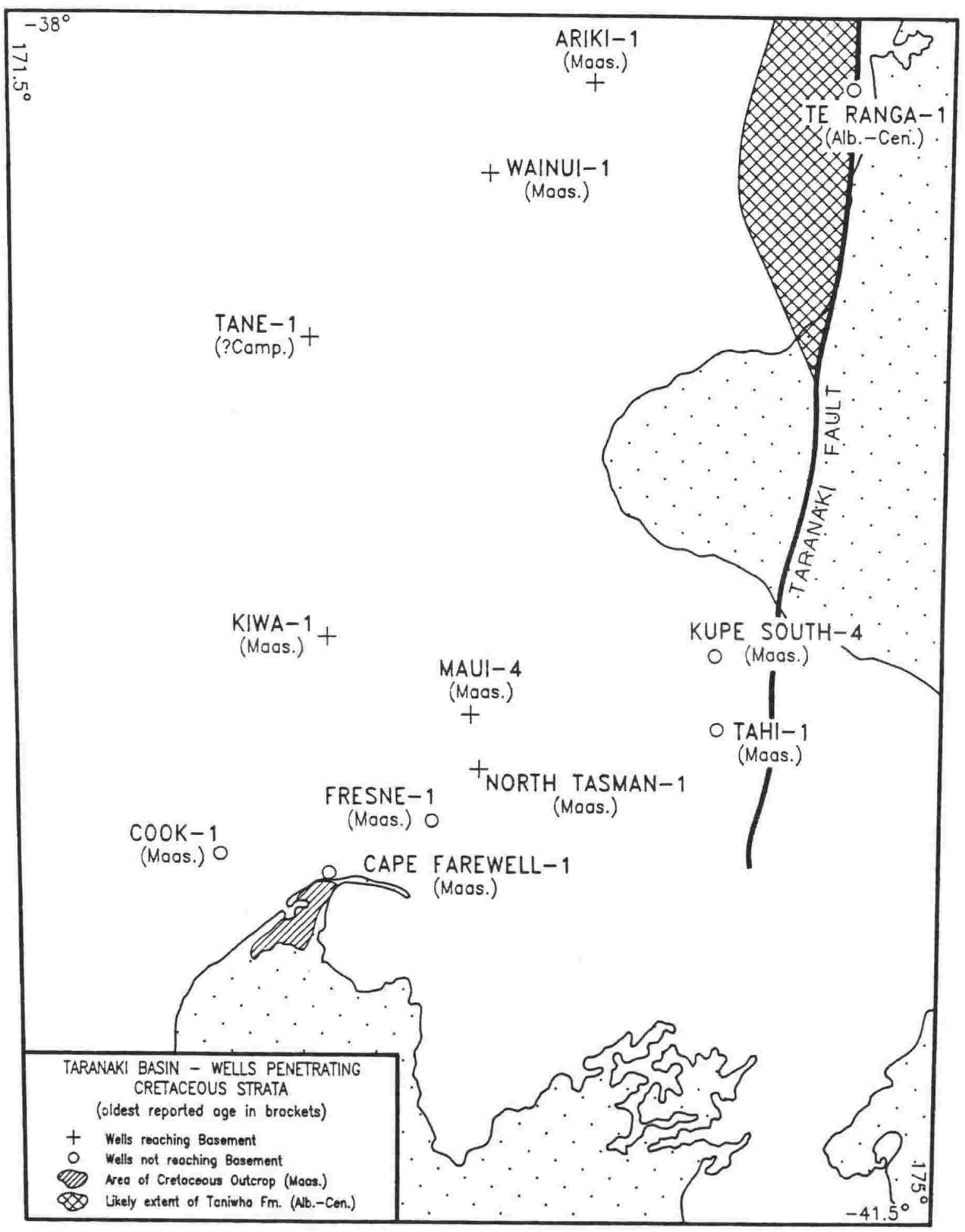

Figure 7.2 Likely extent of the Taniwha Formation, based on isopach trends, seismic facies, and well control. 
resolution is very poor at the burial depths of the unit, which precludes identification of seismic facies with any certainty. Figure 5.3 is an example of some of the better quality onshore data from this unit. The mid late-Cretaceous seismic horizon has been interpreted under the Taranaki Peninsula as a structural horizon, not on seismic-stratigraphic grounds. The nature of the sediments underlying the horizon is difficult to ascertain, and the possibility that thin Taniwha Formation equivalent rocks underlie portions of this area, or that the horizon has been misinterpreted and only the upper-Cretaceous seismic unit is present, cannot be ruled out.

Figure 7.3 is a diagrammatic paleogeographic map of Taranaki Basin near the end of Rakopi Formation sedimentation, about 71 million years ago. The fault-proximal fans are postulated, but the Otimataura Conglomerate Member in the Pakawau Basin was probably deposited in such fans. The large hatched area in the northeastern corner of the basin is the maximum extent of the erosional truncation which has removed Rakopi Formation and causes the Taniwha Formation to subcrop the North Cape Formation. This unconformity has been recorded in the Te Ranga-1 well (Shell, BP and Todd 1986), and its extent is mapped here from seismic reflection data.

Illustrated on Figure 7.3 is a postulated throughgoing drainage system flowing from south to north along the trend of the Taranaki Rift subbasins. This drainage system cannot be verified from present data, but given the swampy conditions which coal-measure sedimentation implies, such drainage seems likely. Lacustrine environments are also likely in such an environment. The probable north-to-south propagation of the North Cape Formation transgression discussed in Chapter 6 indicates any net drainage was probably northward, from highlands in the south towards the New Caledonia Basin in the north.

Leeder and Gawthorpe (1987) reviewed a number of models for sedimentation in rift-related grabens. The subbasins of the Taranaki Rift during the deposition of the Rakopi Formation, as discussed above, would be classed as "continental 


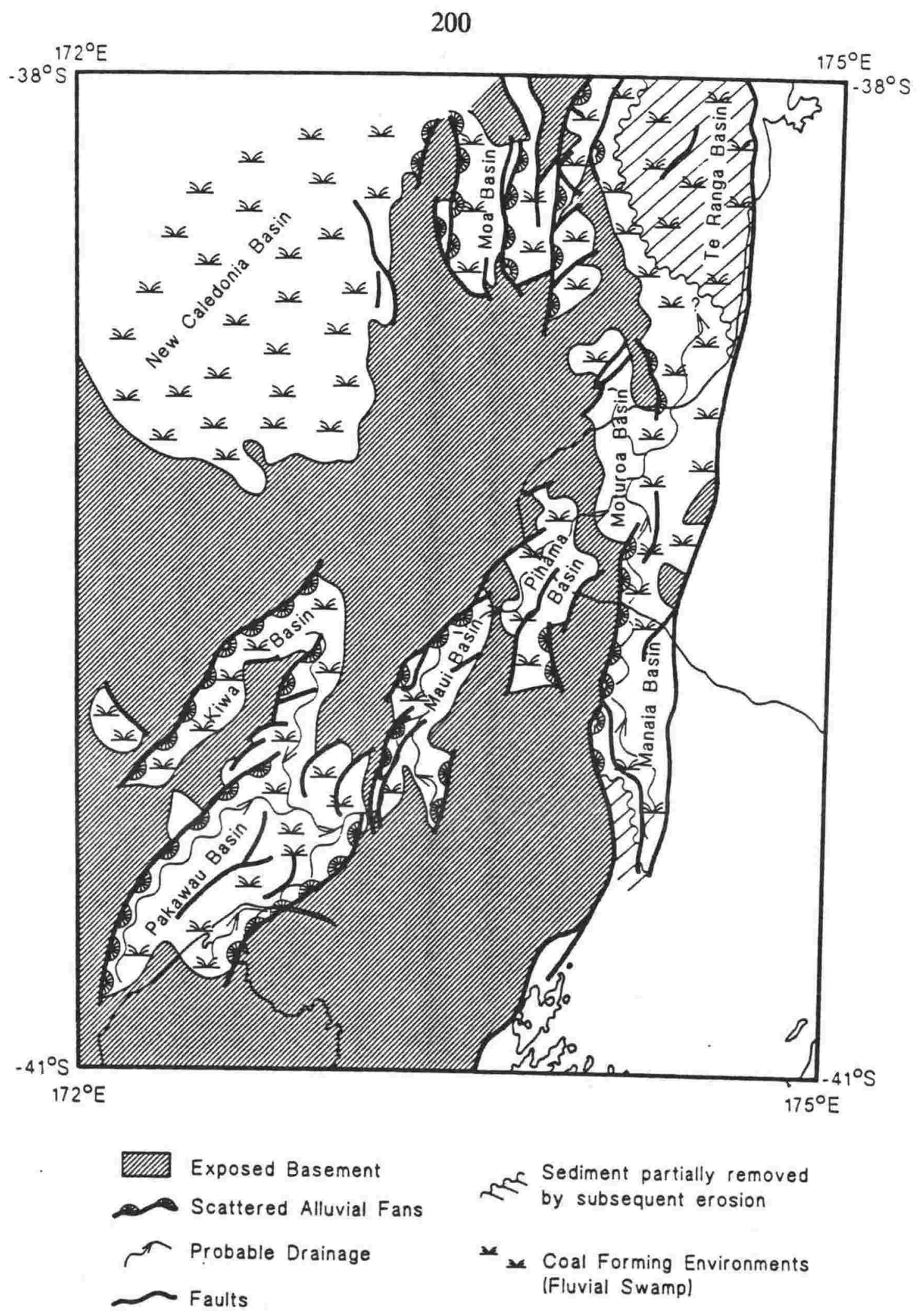

Figure 7.3 Paleogeography of Taranaki Basin near the end of Rakopi Formation sedimentation (about $71 \mathrm{Ma}$ ). 
half-grabens with axial through drainage", in their terminology. They also point out that the axial drainage can pass through more than one half-graben of a rift system, such as in the Rio Grande Rift of the southwest U.S. Figure 7.4 (from Leeder and Gawthorpe 1987) is an isometric diagram of a continental basin with through-drainage.

\subsection{Upper late-Cretaceous seismic unit}

The upper late-Cretaceous seismic unit consists entirely of the North Cape Formation and its subsidiary members. The North Cape Formation is a north-to-south transgressive unit, with a variety of environments represented, ranging from outer shelf to terrestrial. As such, it also has a variety of seismic facies associations. These associations are:

Lower coastal plain deposits. These terrestrial to paralic, coal bearing deposits are represented by the Puponga and Wainui members. On seismic reflection profiles these deposits are fairly thin (usually only a few hundred metres thick), with hummocky, discontinuous, variable amplitude internal reflectors. The reflection signature is very similar to that of the Rakopi Formation mentioned above. Figure 2.2 illustrates these sediments resting on basement on the Western Platform.

Nearshore sand deposits. Many laterally continuous, high amplitude reflectors are present in the upper North Cape Formation. Sangree and Widmier (1979) ascribe high-continuity, high amplitude reflectors to shallow marine clastics deposited primarily by wave transport. Such reflectors are most prominent in the synclinal basin between the wells Wainui-1 and Tane-1, as illustrated in Figure 7.5. The presence of clean, well sorted shallow-marine sands in these wells supports their interpretation as nearshore deposits. Similar reflectors are also present in other parts of the study area, including at the very top of the North Cape Formation sequence in the Pakawau Basin (see Figure 4.14). 


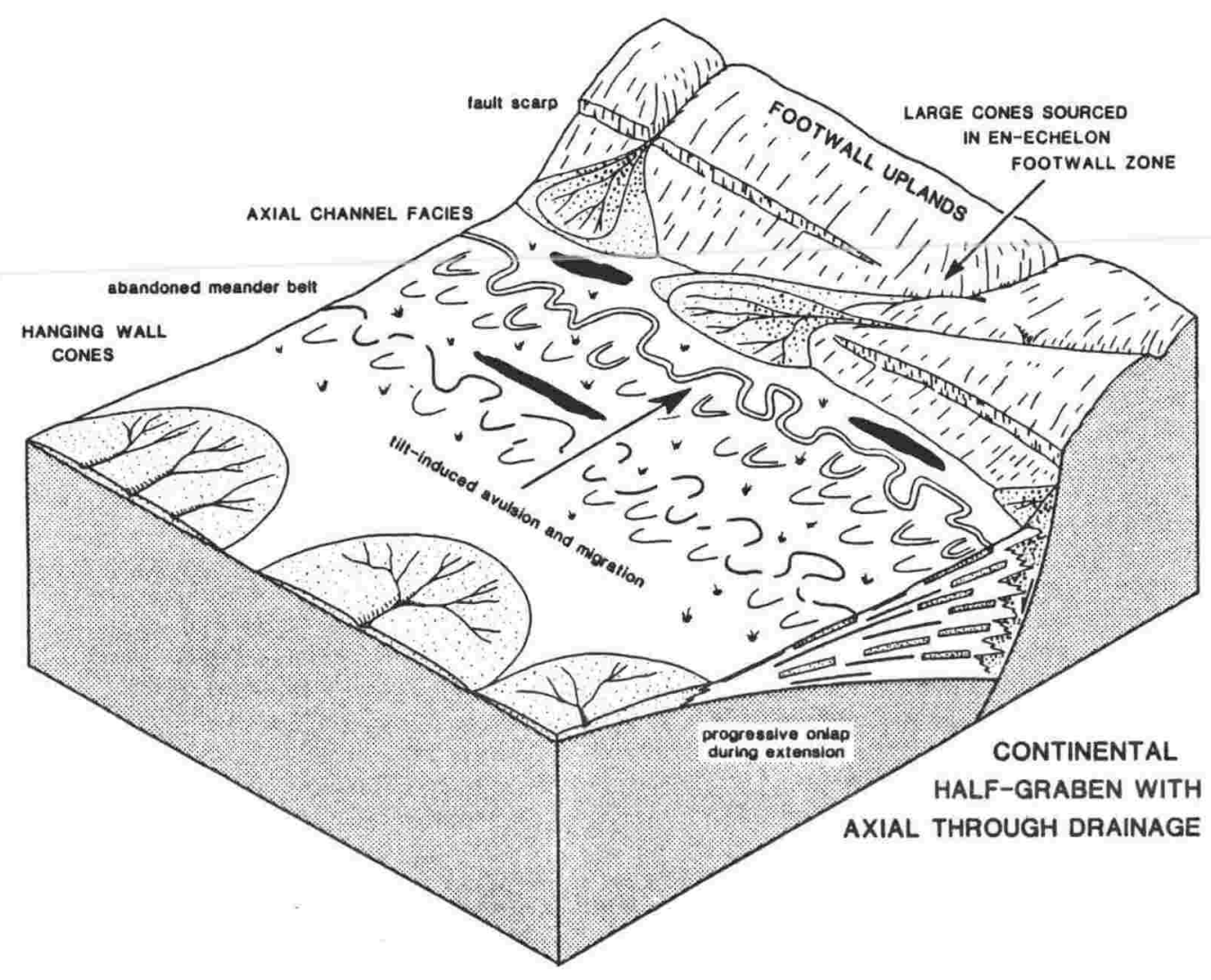

Figure 7.4 Isometric diagram for a continental half-graben with axial through drainage, showing distribution of sedimentary facies. After Leeder and Gawthorpe (1987). 
203

$\perp M \perp S P U O J \partial S$

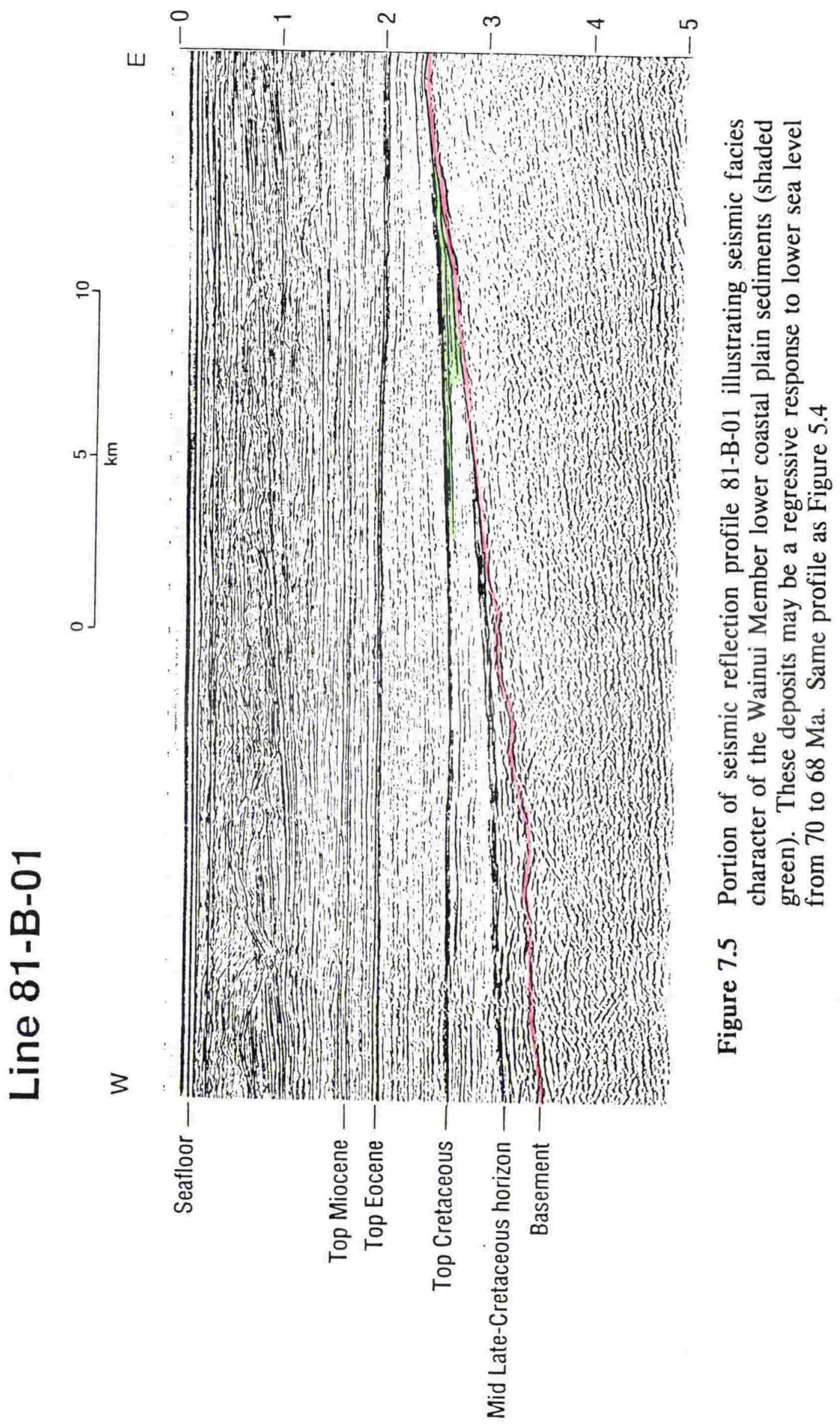


Marine clastic deposits. North Cape Formation offshore-marine sequences have been encountered in several wells in Taranaki Basin. These sequences are correlated with a seismic reflection signature of low amplitude wavelets with variable lateral continuity (Figure 7.5). Sangree and Widmier (1979) attribute this signature type to marine clastics deposited under low energy conditions. The low amplitudes mean that variations in seismic data processing can dramatically affect the displayed character of this unit. With different data processing sequences being applied to different data sets, this unit can be difficult to correlate between various seismic surveys. In particular, the automatic gain control (AGC) routine applied to the data, and the gain-window selected, can have a major effect on the displayed amplitude of seismic events. This facies is, however, the most widespread of the North Cape Formation seismic facies, being present in all of the rift subbasins.

Possible fan-delta facies. This seismic facies is characterized by chaotic, incoherent internal reflectors and thickening adjacent to faults. The only well control for this unit is from Fresne-1, where most of the North Cape section consists of the massive Fresne Conglomerate Member. Small areas of possible fan-delta facies are also located in the Manaia Graben, adjacent to the Taranaki Boundary Fault.

Possible tidal-channel facies. Adjacent to the Maui Field, north of the Maui-4 well, is a region in which the North Cape Formation seismic sequence contains broad, low relief channel forms. In Maui- 4 the equivalent unit is a marine sandstone and silty shale sequence, with porosities in the range 10-17\%, and some minor hydrocarbon shows (Shell BP and Todd 1970). Given the restricted nature of the unit, and the possible enclosed marine basin to the south, this seismic facies is thought to represent tidal channels of latest Cretaceous age.

The recognition and mapping of the seismic facies discussed above allows paleogeographic maps to be prepared for the upper late-Cretaceous unit (North Cape Formation). Two paleogeographic maps at different times during the 
deposition of the North Cape Formation are presented here as figures 7.6 and 7.7. Figure 7.8 is a simplified isopach map of the North Cape Formation provided for reference.

Figure 7.6 shows the interpreted environment at a maximum sea-level low stand, which forced a seaward migration of the shoreline deposits. Deposition of the North Cape Formation lasted from about $71 \mathrm{Ma}$ until the end of the Cretaceous at about 66.5 Ma. This low-stand event, discussed more fully in Section 7.5, occured at about $68 \mathrm{Ma}$.

Figure 7.7 shows the interpreted paleogeography at the very end of North Cape Formation sedimentation (about 66.5 Ma). Marine conditions prevailed over much of the Taranaki Basin region, with some areas of lower coastal plain and shoreline deposition. Areas where no latest Cretaceous sediment are present were probably exposed basement hills. The low relief on the basement surface that was inundated during the Paleocene, and the lack of large volumes of coarse clastic sediment throughout much of the basin in the latest Cretaceous, indicate that these hills were probably low relief features.

On figures 7.6 and 7.7, the Taranaki Rift is shown to be a major, tidal embayment during the latest Cretaceous. This embayment covered all of the subbasins of the rift, and shoreline, coastal plain, and estuarine deposits are preserved around its shores. An inlet of this size could have had substantial tidal currents. Sediments originating in the basin hinterland must have entered the basin by way of estuaries and fans into the still subsiding subbasins, and then been reworked and distributed by tidal, shoreline and marine processes. The paleogeography of this unit will be discussed more fully in Chapter 8 .

The northeast corner of the map area shows the region of late Cretaceous to Paleocene truncation which exposed the Taniwha Formation. The $50 \mathrm{~m}$ thick latest-Cretaceous siltstone recorded in the Te Ranga- 1 well indicates that at least parts of this unconformity were inundated by the end of the Cretaceous. This is 


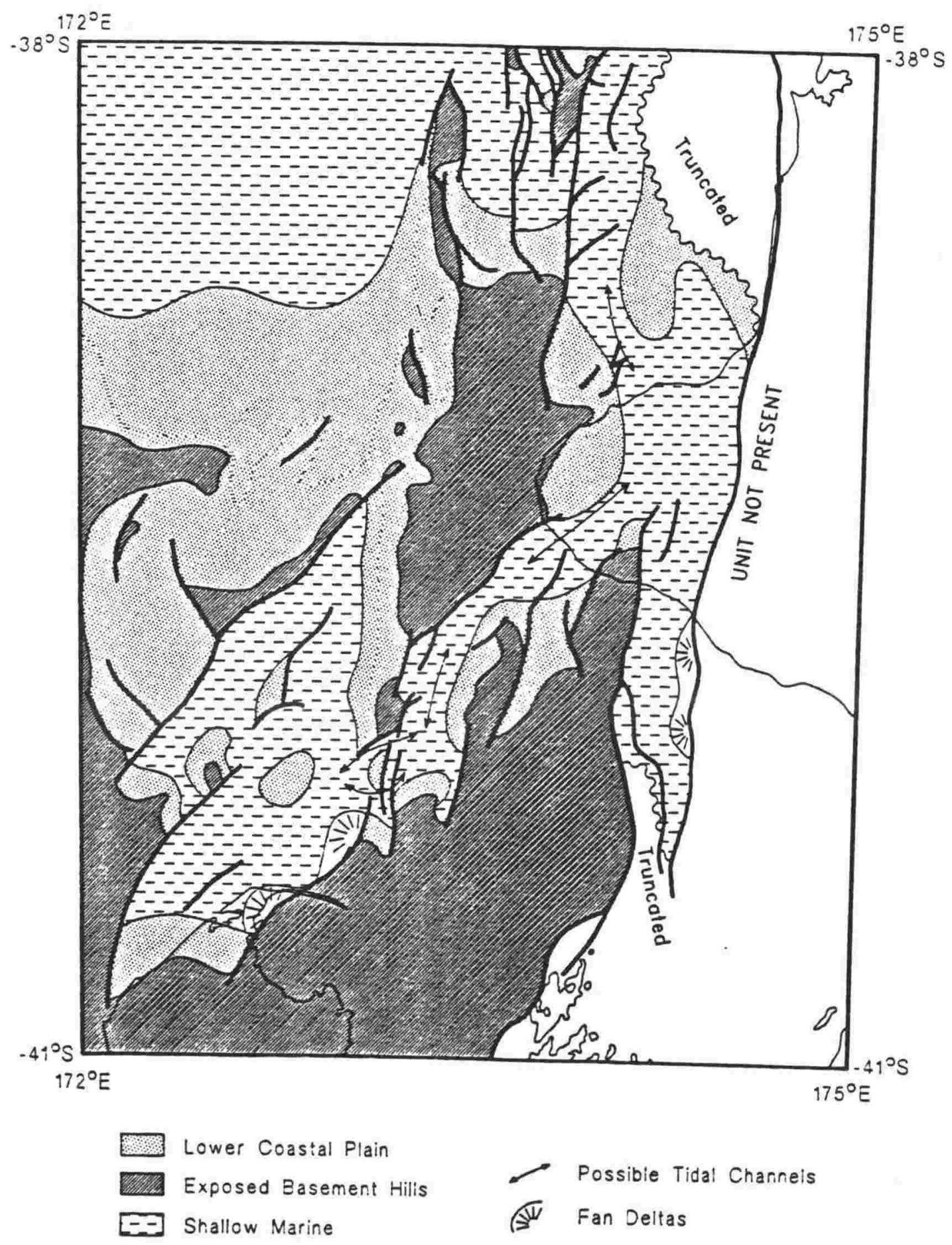

Figure 7.6 Paleogeography of Taranaki Basin at the sealevel low-stand (about $68 \mathrm{Ma}$ ) during North Cape Formation deposition. 


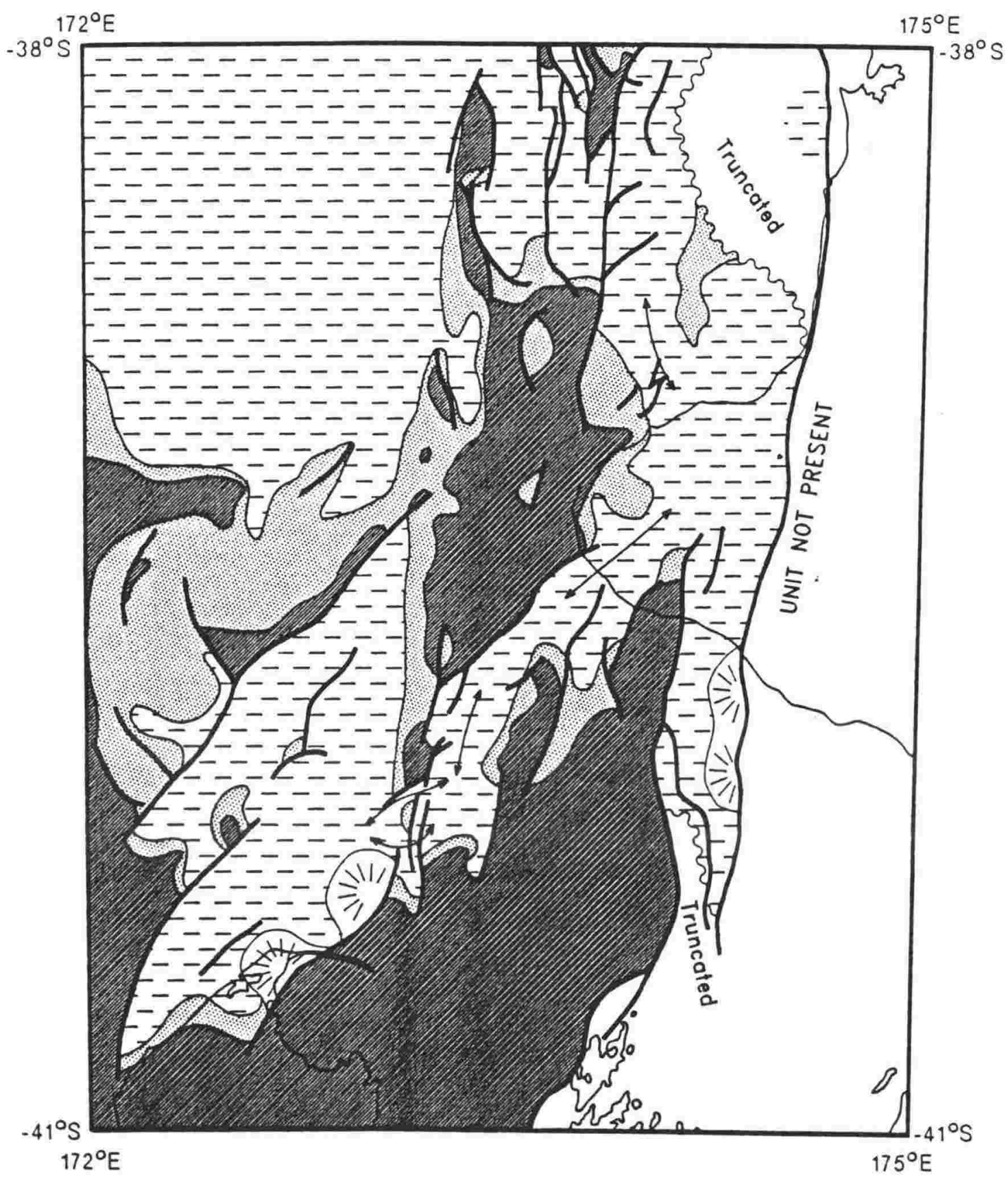

Lower Coastal Plain

Exposed Basement Hills

- Shallow Marine

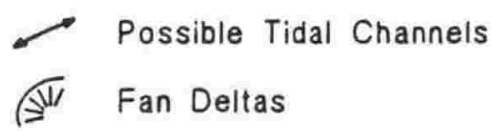

Figure 7.7 Paleogeography of the upper North Cape Formation at latest Cretaceous time (about 66.5 Ma). 


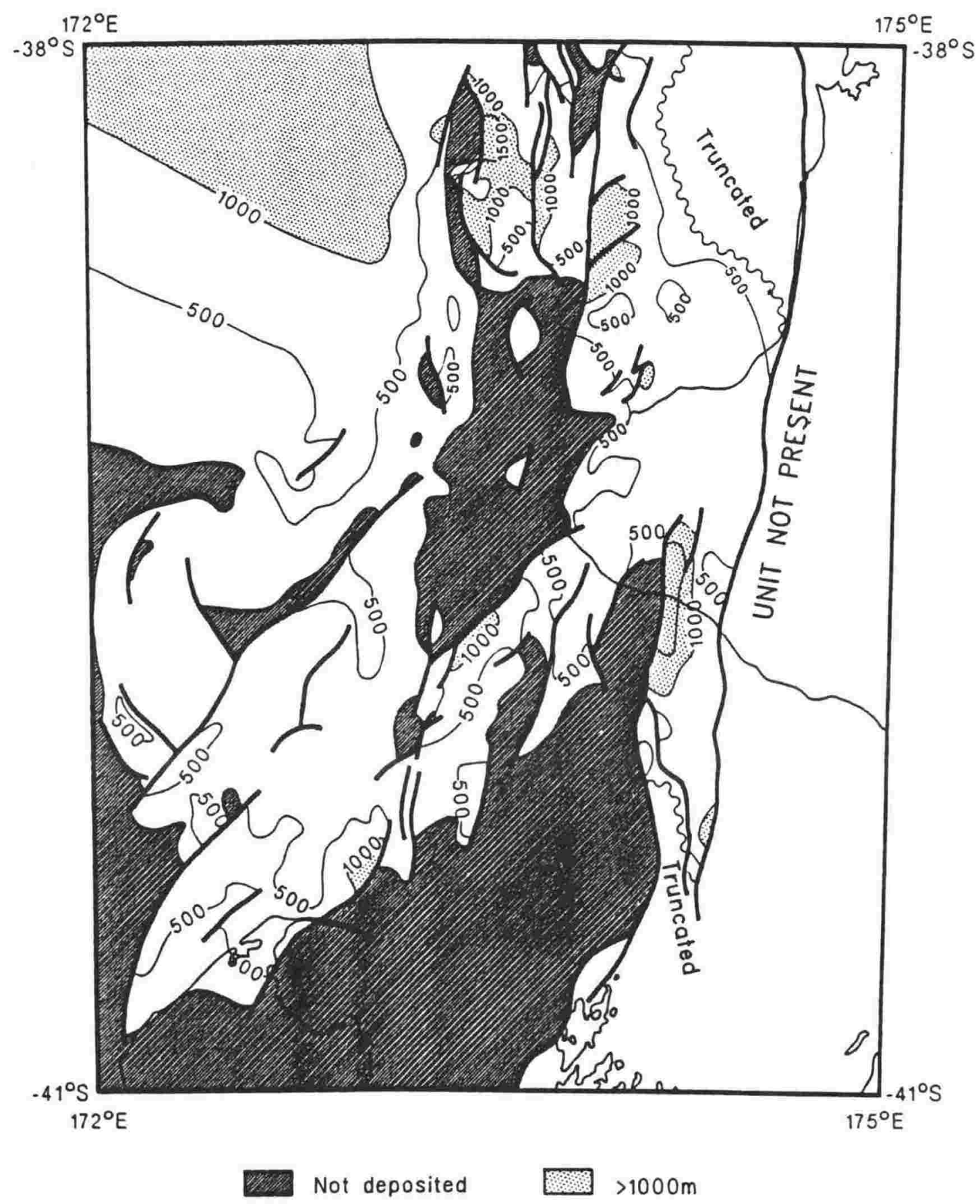

Figure 7.8 Generalized isopach of the North Cape Formation, Taranaki Basin. 
indicated Figure 7.7 by a marine facies pattern in the vicinity of the Te Ranga-1 well site. Much of the region of the unconformity may have similar marine sediments resting on it, but seismic resolution is not sufficient to confirm this.

\subsection{Seismic reflection evidence for eustatic fluctuations}

As mentioned above, seismic reflection facies interpretation can provide information about sea level fluctuations. In Taranaki Basin, no information on sea level changes can be deduced from the Rakopi Formation, as the record is entirely terrestrial. Within the North Cape Formation, however, the record of a major marine transgression is preserved, and with it some evidence of eustatic fluctuations.

Thoughout the late Cretaceous history of the Taranaki Rift, most of the region was subsiding. Subsidence rates were low for a continental rift, with a maximum of $4000 \mathrm{~m}$ of sediment being deposited in about 10 million years (a rate of 400 $\mathrm{m} / \mathrm{my}$ ). Thoughout most of the region the rate of subsidence was less than 100 $\mathrm{m} / \mathrm{my}$. These estimates include the effect of sediment loading caused by the infilling of the rift.

During the deposition of the Rakopi Formation the rift was above sea level. By the beginning of North Cape Formation deposition the region had subsided sufficiently for marine sediments to flood the rift. This flooding occurred quite rapidly, starting about 71 to 72 million years ago (see Enclosure 6.3). The easiest way to explain this rapid rise in relative sea level is to couple the effect of rift subsidence with an eustatic rise in sea level. About $70 \mathrm{Ma}$ (near the $O$. porifera/A. acutulum dinoflagellate zone boundary, as recorded in wells Tane-1 and Wainui-1, see Chapter 6) the Wainui Member started to regress northwestward from a position near the Tane- 1 and Wainui- 1 wells. The seismic reflection character of this regression is illustrated in Figure 7.5. The outbuilding of the Wainui Member may have been in response to a slowing of the relative 
subsidence rate, brought on by an eustatic sea-level fall. The Wainui Member reached its maximum extent (Figure 7.6) about $68 \mathrm{Ma}$ (in the upper A. acutulum dinoflagellate zone, as recorded in Wainui-1). Marine flooding then resumed, and by the end of the Cretaceous, at $66.5 \mathrm{Ma}$, most of the rift was flooded. This was the maximum extent of the transgression. A major regression, recorded by the Farewell Formation and other formations of the lower Kapuni Group, then followed in the Paleocene.

The North Cape Formation may be a partial record of two eustatic cycles. Low sea level stands are postulated at about 71 to $72 \mathrm{Ma}$ (just prior to rift flooding) and again at $68 \mathrm{Ma}$ (maximum Wainui Member regression). These were followed by high sea level stands at 70 (just prior to the Wainui Member regression) and $66.5 \mathrm{Ma}$ (maximum rift flooding). This record can be compared with the global sea-level curve proposed by Haq and others (1987). On this curve, global sea-level lows are thought to have occured at 71 and 68 million years, and sea-level highs at $69.5 \mathrm{Ma}$ and at the Cretaceous Tertiary boundary (66.5 Ma). Thus the Taranaki Basin record and the global sea-level curve proposed by Haq and others (1987) are in general agreement for the latest Cretaceous sea level record.

\subsection{References}

Haq, B.U.; Hardenbol, J.; Vail, P.R. 1987: Chronology of fluctuating sea levels since the Triassic. Science, Vol. 235: 1156-1167.

Leeder, M.R.; Gawthorpe, R.L. 1987: Sedimentary models for extensional tilt-block/half-graben basins. In: Continental Extensional Tectonics, Geological Society Special Publication No. 28: 139-153. 
Sangree, J.B.; Widmier, J.M. 1979: Interpretation of depositional facies from seismic data. Geophysics 44(2): 131-160.

Shell BP and Todd 1970: Maui-4 (023/01). Unpublished open-file petroleum report 543, filed at DSIR Geology and Geophysics, Lower Hutt.

Shell BP and Todd 1986: Well resume Te Ranga-1 PPL 38107 Taranaki Basin, New Zealand. Unpublished open-file petroleum report 1197, filed at DSIR Geology and Geophysics, Lower Hutt.

Shell Oil Company 1987: Seismic sequences as applied to basin- fill analysis: Taranaki Basin, New Zealand. In: Bally, A.W. (ed.) Atlas of seismic stratigraphy. American Association of Petroleum Geologists, Studies in geology No. 27: 53-71. 
CHAPTER 8: LATE CRETACEOUS PALEOGEOGRAPHY OF TARANAKI BASIN

\subsection{Chapter abstract}

The Taranaki Rift was an active continental oblique transform synchronous with the opening of the Tasman Sea during the late Cretaceous. The preserved sedimentary record within the Taranaki Rift indicates that tectonism started about the time of the first oceanic crustal emplacement in the Tasman Sea, and ended with the cessation of sea floor spreading.

The Taranaki Rift was at first a terrestrial feature, with thick sequences of coal measures deposited as the Rakopi Formation. The contact between the Rakopi and the overlying North Cape Formation marks a significant marine transgression in the basin. The North Cape Formation was deposited in a marine to marginal marine environment associated with a major embayment into the proto-New Zealand continental block (Figure 7.7).

The climate during the deposition of both the Rakopi and North Cape Formations was cool temperate, with substantial rainfall and humid conditions. Storms, strong tides and earthquakes may have contributed to the input and distribution of sediments in the active geologic environment of the Taranaki Rift.

\subsection{Introduction}

During the final 10 million years of the Cretaceous, Taranaki Basin evolved from an incipient continental rift composed of individual subbasins into a large shallow marine embayment. Prior to formation of the rift subbasins, the region was probably a high-standing continental block, incorporating the present western 
North Island and the northwest of the South Island with the Challenger Plateau, the Lord Howe Rise, and possibly the Norfolk Ridge system.

The timing of initiation of the Taranaki Rift is difficult to constrain. Sea floor spreading in the Tasman Sea is believed to have been active from about $82 \mathrm{Ma}$ to about $60 \mathrm{Ma}$ (Weissel and Hayes 1977). The continental rifting which preceded the initiation of sea floor implacement may have been active for a considerable time prior to this, but there is no evidence in Taranaki Basin for rift-related sedimentation prior to about $80 \mathrm{Ma}$ (Chapter 6).

The first sediments were deposited in the West Coast Rift about $100 \mathrm{Ma}$ (Pororari Group, Laird 1980). This may be approximately the same time as the Taniwha Formation of northern Taranaki was being deposited, but no relationship between these two sequences can be determined. Both sets of rocks may have been deposited in response to the initial breakup of the Gondwana landmass prior to seafloor spreading in the Tasman Sea. Alternatively, the Taniwha Formation may be a pre-rift sequence deposited along the margin of the Gondwana Continent.

The Taranaki Rift probably opened as a left-lateral oblique transform starting about $80 \mathrm{Ma}$, or coincident with the start of Tasman Sea spreading (Chapter 3). Although most Taranaki Rift tectonic activity was restricted to late Cretaceous times, activity on some rift-controlling faults continued into the Paleocene, and probably ceased with the cessation of Tasman Sea spreading about $60 \mathrm{Ma}$. Total offset across the Taranaki Rift was probably about $10 \mathrm{~km}$, with about $20 \mathrm{~km}$ of sinistral motion along the rift (see Section 3.4).

\subsection{Late Cretaceous climate}

The presence of coal beds in the both the Rakopi and North Cape formations indicates that the Taranaki region at that time had a damp, organically productive 
climate suitable for the establishment of coal forming environments. The Rakopi Formation contains numerous thin coal and carbonaceous siltstone beds, interbedded with fluvial silts and sands. This sequence indicates moist conditions which allowed for lush growth and stream development. Preservation of the organic matter in coals and carbonaceous units indicates a high water table and standing water, which prevented the total biodegradation and oxidation of the organic matter.

In a study of the fossil flora of the Pakawau Group outcrop sequence, Mildenhall (1968) concluded that the preserved Pakawau flora was representative of a cool-temperate climate. This conclusion was based on leaf morphology and size. The presence of well-defined growth rings in wood fossils was interpreted by Mildenhall as indicating a climate with marked seasonal changes.

Pocknall and others (1989) concluded from the presence of well-perserved plant material and of Spaghnum moss spores that the late Cretaceous sequences preserved in the Manaia Basin, and sampled in the Kupe South-4 and Tahi-1 wells, were deposited in or near wet, swampy conditions.

The conclusion that the late Cretaceous climate of the Taranaki Basin region was cool-temperate, with abundant moisture, is in agreement with other studies of the climate of the greater New Zealand region. Couper (1960) used evidence from the distribution of Nothofagus species to postulate that the late Cretaceous through Eocene in New Zealand was a period of warming, starting in a cool temperate environment and culminating in subtropical Eocene conditions. This was independently confirmed by Hornibrook (1978), using oxygen isotope and paleontological evidence.

Stevens (1985) interpreted the late Cretaceous climate in similar terms, indicating that New Zealand was a land of thick forests and vegetation thriving in cool- or cold-temperate conditions, with well defined seasons. These forests probably 
consisted of mixed taxa, including Nothofagus and Agathis, and a wide variety of podocarps and ferns (Mildenhall 1980).

In a study of the paleoclimate of the Australian Gippsland Basin, Shanmugam (1985) gave evidence that the Southern Australia and New Zealand region was, in the late Cretaceous and early Tertiary, within the temperate zone with ocean temperatures of $11^{\circ}$ to $20^{\circ} \mathrm{C}$. The detached land mass of New Zealand, surrounded by temperate seas, would most likely have experienced substantial rainfall and humid conditions.

\subsection{Paleogeography of the Rakopi Formation}

Initially the Taranaki Rift propagated through a high-standing continental block, forming steep fault scarps, with local fans, such as those represented by the Otimataura Conglomerate Member exposed onshore in Northwest Nelson. Most of the Rakopi Formation was deposited in individual subbasins, probably connected with through-going drainage. The thickness of sediments in these basins exceeds $3000 \mathrm{~m}$ against some bounding faults, but is generally less than $2000 \mathrm{~m}$. The moist, temperate climate led to high organic productivity and the deposition of coal-bearing strata. In the cool-temperate climate, storm and flood events may have been common, giving rise to mass-wasting and the catastrophic input of sediment into the subbasins.

Figure 7.3 is a paleogeographic map of the basin during Rakopi Formation sedimentation. The basin is portrayed in its present configuration because the lateral tectonic movements within the basin since Rakopi Formation sedimentation have been quite small, generally less than a few kilometres (see Chapter 2). Northward drainage is portrayed because the later Cretaceous transgression entered the rift from the north, and hence a basin gradient in that direction seems likely. 
The Taranaki Rift was an active feature during the deposition of the Rakopi Formation, with both normal and left-lateral active faults. Earthquake activity was probably moderate to high, with seismic events common. Bonilla and others (1984) show that for presently-active normal faults, magnitudes greater than 7.5 are not expected. Strike-slip faults, however, can generate seismic events of magnitude greater than 8 . If the region did experience large magnitude earthquakes, slope failures and soft-sediment deformation may have been common.

\subsection{Paleogeography of the North Cape Formation}

The end of Rakopi Formation sedimention is marked by a rapid, regional transgression throughout most of Taranaki Basin. This transgression propagated from north to south about 72 to $70 \mathrm{Ma}$. By 70 Ma most of the subbasins which accommodated Rakopi Formation sedimentation had been flooded, and were depocentres for marginal marine clastic sediments. The transgression reached its peak very near the end of the Cretaceous at $66.5 \mathrm{Ma}$, and was followed by a regional Paleocene regression affecting the southern part of the basin.

On figures 7.6 and 7.7, the Taranaki Rift is shown to be a major, tidal embayment during the latest Cretaceous. This embayment covered all of the subbasins of the rift, and coastal plain, estuarine, and shoreline deposits were preserved around its shores. Lower coastal plain and shoreline deposits are common adjacent to high-standing basement blocks, except where active faulting prevented their establishment. During the deposition of the North Cape Formation, sedimentation within the Taranaki Rift was in near-equilibrium, with sediment supply, subsidence, and eustatic fluctuations causing only minor variations in the shape of the marine embayment. Water depth remained shallow throughout, and there is no evidence for other than near-shore to shelf sedimentation. 
The latest Cretaceous Taranaki Basin embayment was over $300 \mathrm{~km}$ long from north to south, and up to $150 \mathrm{~km}$ wide. A marine embayment of this size could have had substantial tidal currents. These currents would have been strongest in constricted areas, and a few such constrictions are shown as possible tidal channels on Figure 7.7. The long, narrow shape of the embayment may have led to amplification of the tidal range in the southern portions of Taranaki Basin, where a tidal range of several metres may have existed. Tidal reworking of sediment, especially in the southern portions of the embayment and in the tidal constrictions seems very likely and may have led to the deposition of very clean, well sorted sands.

Sediments originating in the basin hinterland probably entered the basin by way of estuaries and fault-adjacent fans. These sediments were then reworked and distributed by tidal, shoreline and marine processes. The humid climate would have ensured ample runoff, including flood and storm events, and numerous streams and rivers probably entered the marine embayment. Several estuary-like marine inlets are portrayed on the paleogeographic map of the latest Cretaceous (Figure 7.7), including some underlying the Western Platform. Rivers entering these estuaries were probably draining the highlands to the south, as well as the then-exposed Challenger Plateau to the west.

Active faulting (normal and left-lateral) persisted throughout the deposition of the North Cape Formation. The active faults not only controlled deposition, as shown by sedimentary thicknesses of over $1000 \mathrm{~m}$ adjacent to the normal faults, but were probably seismogenic, giving rise to catastrophic sediment input and deformation. Mobilization of sediments by tide and weather was probably another feature of the Taranaki region during the latest Cretaceous. 


\subsection{Conclusions}

The late Cretaceous geology of Taranaki Basin is the story of the formation of a continental rift and its subsequent subsidence and oceanic flooding. Because almost all of the late Cretaceous record is in the subsurface, and subsurface data is limited at present, an outline of the paleogeography of the region is all that can be ascertained. At present, the late Cretaceous is underexplored in Taranaki Basin, with only twelve exploration wells intersecting late Cretaceous sediments. However, as petroleum exploration advances in the basin, more information on the subsurface geology of the basin will become available.

The Rakopi Formation is the most likely source rock sequence for the hydrocarbons presently being produced from Taranaki Basin (see Chapter 6). Conversely, the North Cape Formation is almost devoid of organic matter, except in localized deposits, and may not contribute substantially to the hydrocarbon generating potential of the basin. The paleogeographic model of the North Cape Formation developed in the present study does indicate excellent potential for petroleum resevoir development over a wide area. The association of these strata with the potential petroleum source rocks of the Rakopi Formation, make an attractive petroleum exporation target. The future may well see increased petroleum exploration activity aimed at the late Cretaceous sequence, and perhaps the present study will contribute to that activity.

\subsection{References}

Bonilla, M.G.; Mark, R.K.; Lienkaemper, J.J. 1984: Statistical relations among earthquake magnitude, surface rupture length, and surface fault displacement. Bulletin of the Seismological Society of America 74(6): 2379-2411.

Couper, R.A. 1960: New Zealand Mesozoic and Cainozoic plant microfossils. New Zealand Geological Survey paleontological bulletin 32. 
Hornibrook, N de B. 1978: Tertiary Climate. In: R.P. Suggate, G.R. Stevens and M.T. Te Punga (Editors), The geology of New Zealand. New Zealand Geological Survey. N.Z. Government Printer, Wellington, pp. 436-443.

Laird, M.G. 1981: The late Mesozoic fragmentation of the New Zealand segment of Gondwana. In: Cresswell, M.M. and Vella, P. (eds), Gondwana Five. Selected papers and abtracts of papers presented at the Fifth International Gondwana Symposium. Balkema, Rotterdam, 311-318.

Mildenhall, D.C. 1968: The fossil flora of the Pakawau Group, NW Nelson, New Zealand. Unpublished MSc thesis, Department of Geology, Victoria University of Wellington.

Mildenhall, D.C. 1980: New Zealand late Cretaceous and Cenozoic plant biogeography: a contribution. Palaeogeography, Palaeoclimatology, Palaeoecology 31: $197-233$.

Pocknall, D.T.; Strong, C.P.; Wilson, G.J. 1989: Biostratigraphy of Kupe South-4, offshore petroleum exploration well, South Taranaki Bight. New Zealand Geological Survey report PAL 144.

Shanmugan, G. 1985: Significance of coniferous rain forests and related organic matter in generating commercial quantities of oil, Gippsland Basin, Australia. American association of petroleum geologists bulletin 69(8): 1241-1254.

Stevens, G. 1985: Lands in collision: discovering New Zealand's past geography. Science Information Publishing Centre, DSIR, Wellington. 129 p.

Weissel J.K.; Hayes, D.E. 1977: Evolution of the Tasman Sea reappraised. Earth and planetary science letters 36(1977): 77- 84. 


\section{APPENDICES}

1. Subsurface maps of the Taranaki Basin region, New Zealand. Glenn P. Thrasher and June P. Cahill. New Zealand Geological Survey report G-142, 1990.

2 Unpublished paleontological data used in this study. 


\section{SUBSURFACE MAPS OF THE TARANAKI BASIN REGION, NEW ZEALAND}

Glenn P. Thrasher and June P. Cahill New Zealand Geological Survey Report G142 . 
This map set was developed at the New Zealand Geological Survey, Lower Hutt. G. Thrasher was the geophysicist in charge of the project, and was responsible for most of the interpretation and map preparation. Geophysical interpretation was supplemented by $P$. Anderton, who was responsible for the South Wanganui Basin interpretation, and by J. Cahill, J. Beggs, P. King, and P. Robinson.

Numerous people have given assistance in the technical facets of this project. Data organisation and manipulation was mainly the responsibility of J. Cahill. Major technical support was provided by M. Ogilvie, P. Callaghan, G. Cutress, P. Matheson, and D. Milton. Computer routines used during the interpretation and initial map preparation were developed by L. Maasland, R. Wood, G. Thrasher and J. Cahill. Final map production was the responsibility of the staff of GECO NZ, in particular P. Brown, M. McCormack and L. Chapman.

Map editing and quality contol was undertaken by D. Heron. The text was written by G. Thrasher. 


\section{CONTENTS}

Page

Section 1:

Introduction

Section 2:

Regional Geologic History and Stratigraphy

Section 3:

Data Used

Section 4:

Data Interpretation

Section 5:

Depth Conversion

Section 6:

Problem Areas

18

Section 7:

Special Products Available

22

Section 8:

References

24

Appendix 1:

Map Sheets in this set

26

Appendix 2:

Seismic Line Statistics

Appendix 3:

Wells Used 


\section{SECTION 1: INTRODUCTION}

The map series which accompanies this report illustrates a number of regionally-important seismic reflection horizons and units within Taranaki Basin. The series consists of four two-way reflection-time maps and eight seismically derived isopach and structure maps. These maps were developed at the New Zealand Geological Survey, Lower Hutt, and form part of an ongoing research programme into the geology and resource potential of the Taranaki Basin. They are intended to illustrate the subsurface geology of the region for basin studies purposes. They are not intended for petroleum exploration, although numerous prospects and leads can be identified on them.

Taranaki Basin is a large sedimentary basin located along the western side of New Zealand. The basin is mostly offshore, and underlies much of the continental shelf west of the North Island. New Zealand's only commercial discoveries of hydrocarbons have been from within this basin.

Taranaki Basin is a predominantly north-south, subsurface feature. The basin is bounded to the east by the Taranaki Fault, a large, late-Paleogene to Neogene, reverse fault which offsets basement by over five kilometres. To the west the basement gradually shallows onto the Challenger Plateau, an oceanic bathymetric high. The northern and southern limits of the basin are not well defined. To the north, and northwest, the basin merges with the bathyal New Caledonia Basin, while to the south it merges with the numerous small basins of the northwestern South Island.

The maps associated with this report cover an area of over 100,000 square kilometres. The geographic limits of these maps are:

north: 38.0 degrees $\mathrm{S}$.

south: 41.5 degrees $\mathrm{S}$.

west: 171.0 degrees $\mathrm{E}$.

east: 175.0 degrees $E$. 
The geographic limits of this mapping project have been controlled by the limits of the publicly available database, as well as by the geography of the basin. Much of the subsurface extent of Taranaki Basin is included on the maps. Only to the north of the mapped area, where the basin is open-ended, are the maps not adequate to ascertain the history and present structure of the basin.

The generalised subsurface physiography of the region is illustrated on Figure 1. The labelled physiographic nomenclature follows that of King and Robinson (1988), which is adapted from Pilaar and Wakefield (1978) and Knox (1982). The Taranaki basin is usually divided into four major sub-regions: the Western Platform, Northem Taranaki Graben, Southern Taranaki Graben, and the Southern Zone. The northem and southern Taranaki grabens are sometimes referred to collectively as the Taranaki Graben. The South Wanganui Basin is.a late Neogene feature (Anderton 1981), and is not generally considered a portion of Taranaki Basin, although its offshore extent is included on the regional maps that accompany this report. 


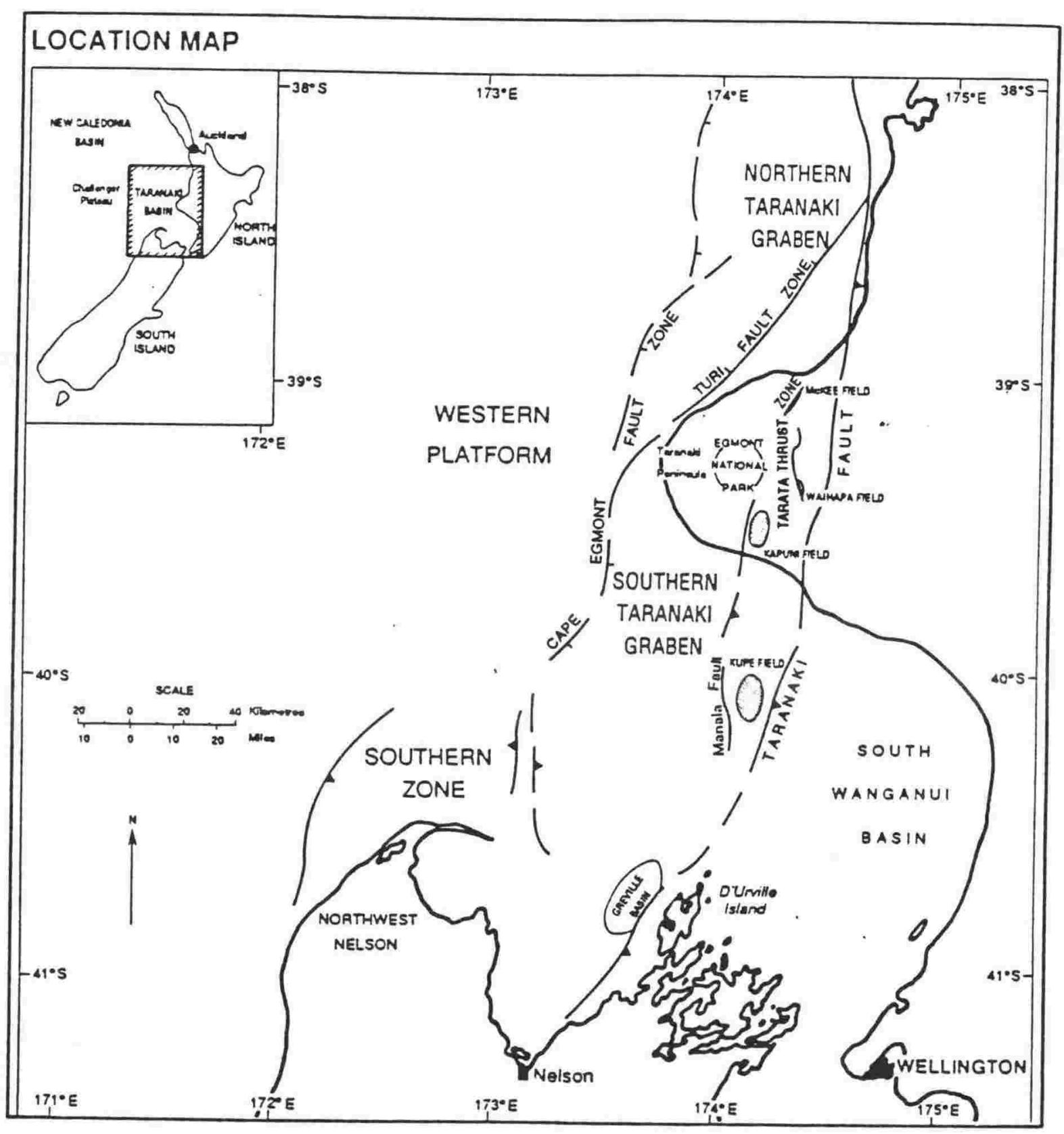

Figure 1. Taranaki Basin physiographic diagram 


\section{SECTION 2: REGIONAL GEOLOGIC HISTORY AND STRATIGRAPHY}

Taranaki Basin first formed during the middle Cretaceous as a series of half-grabens, interpreted as an oblique transform which accommodated the opening of the New Caledonia Basin (Thrasher 1989). The earliest age represented by sediments within Taranaki Basin has not been established, but no sediment older than the New Zealand Clarence series (middle Cretaceous) has been identified (Thrasher 1989). By the end of the Cretaceous, rifting in the New Caledonia Basin had ceased, and the region was gradually cooling. As the region subsided, terrestrial and shallow marine sediments were slowly transgressed by more open marine and oceanic sediments. Slow subsidence continued into the Oligocene; by which time much of the basin was bathyal and sedimentation was predominantly calcareous.

Reverse motion on the Taranaki Fault began in the late Oligocene, depressing the eastern margin of the basin as basement rocks progressively overthrust the basin from the east (King and Thrasher in prep.). Uplift in the hinterland to the east increased the terrigenous sediment supply, leading to the Miocene onset of progradation of a continental shelf across the basin. By the end of the Miocene, compression had propagated across the entire Southern Zone, causing reverse motion on many previously normal faults. This structural development led to the formation of a widespread late Miocene-early Pliocene unconformity across much of the Southern Zone and Southern Taranaki Graben. Also in the late Miocene, volcanism became widespread in the northeast of the basin. This volcanism was expressed as the development of discrete volcanic structures, whose locations are shown on sheet 6, isopach map of Oligocene-Miocene sediments.

In the Plio-Pleistocene, extension and subsidence became dominant in the eastern portions of the basin and sediment supply remained very high. Uplift and erosion in the Southern Zone was offset by the formation and infilling of the Taranaki Graben. Excess sediment has continued to prograde the continental shelf northwestward in a series of giant clinoform-bounded sediment wedges. Throughout the Plio-Pleistocene, systems of contributory channels have been incised into the Taranaki continental slope. These submarine 
channels have helped carry the excess sediment off the continental shelf, and into the New Caledonia basin. One set of these channels, which were incised into the top-Miocene reflector, are shown on sheets 1 and 9 .

Because of the lateral variations in the development of the basin, a single generalised stratigraphic column is difficult to construct for the basin as a whole. Figure 2 shows a stratigraphic column oriented approximately west-to-east from the Western Platform into the Taranaki Graben. This column has been adapted from that presented in King and Thrasher (in prep) by adding the major seismic units that can be correlated throughout the region. This subdivision of the stratigraphic column into seismic units is similar to that recommended for the Western Platform by Thrasher (1988). Briefly, four subsurface reflectors have been interpreted throughout the basin, these are:

1. Seismic basement.

2. Near top Cretaceous (near top Mata).

3. Near top Eocene (near top Amold).

4. Near top Miocene (near top Taranaki).

These four reflectors separate the stratigraphic sequence into 5 seismically mappable units:

1. Igneous and metamorphic basement.

2. Cretaceous sediments (Clarence, Raukumara and Mata Series).

3. Paleocene and Eocene sediments (Dannevirke and Amold Series).

4. Oligocene and Miocene sediments (Landon, Pareora, Southland and Taranaki Series).

5. Post-Miocene sediments (Wanganui Series).

Isopach maps of the last four of these units are contained in the map set, as are two-way-time and structure maps for each of the four reflectors. The maps produced are detailed in Appendix 1. 
8

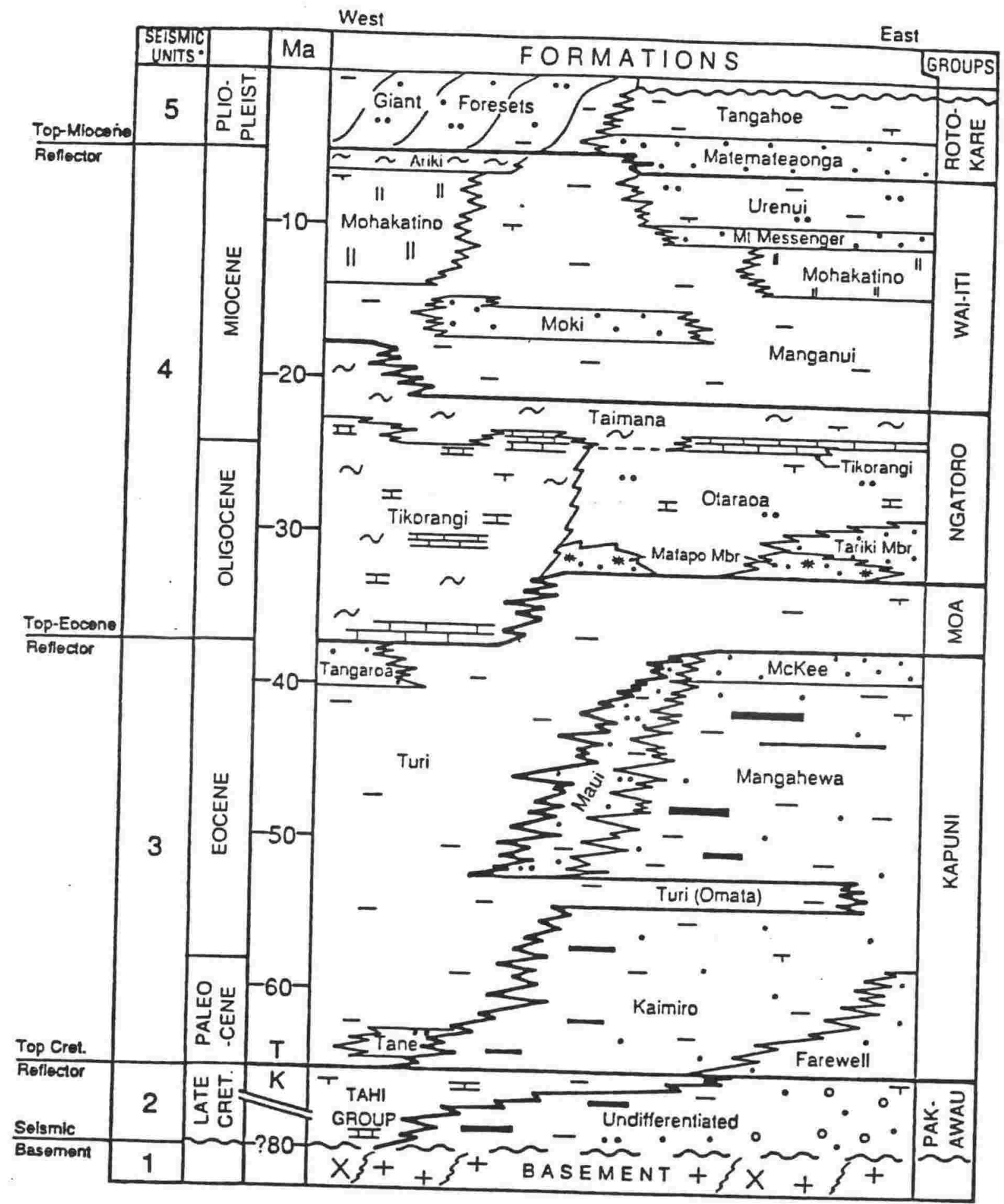
Figure 2 Taranaki Basin Stratigraphic Column (adapted from King and Thrasher, in
prep).

*See text for description of numerbered seismic units 
Throughout this report preference is given to the international geological ime scale 230 terminology. Because paleontologically determined ages from Taranaki Basin are usually reported in terms of the New Zealand geological time scale, a translation must be made. For this report, the time scale of Edwards and others (1988) is used to correlate with internationally recognized units.

\section{SECTION 3: DATA USED}

Most of the seismic reflection data interpreted to produce the maps were collected and processed by petroleum exploration companies holding exploration licences over portions of Taranaki Basin. These data were lodged with the New Zealand Government, and curated by the New Zealand Geological Survey. All of the petroleum exploration data used are publicly available. Some seismic reflection data acquired by the Geophysics Division of the Department of Scientific and Industrial Research were used where the petroleum exploration database was not sufficient to ascertain the subsurface structure. Appendix 2 lists the seismic reflection data used in this study, and includes brief statistics for each line.

The line density of seismic reflection data varies considerably throughout Taranaki Basin. Over highly prospective areas seismic lines are spaced more closely than one kilometre apart, and some 3-dimensional surveys have been collected. In less prospective areas, such as the far west of the Western Platform, seismic lines are often spaced more than 10 kilometres apart. Very few petroleum exploration seismic surveys have included data off the edge of the continental shelf in the north-west corner of the map area.

Because the aim of this project was to produce regional maps on a limited number of horizons, the available data were thinned to produce a grid of seismic profiles with a 5 to 10 kilometre line spacing. In areas of structural complexity more closely spaced lines were interpreted so that the structure could be more accurately imaged. Lines were selected to optimize data quality, line spacing, line length, availability, and ability to image the subsurface geology. Sheet 13 of the map set is a track chart showing the data interpreted, 
and well ties used. A total of 684 lines were interpreted, representing 21,130 line-kilometres of data.

Most of the seismic reflection data used in this study are common-depth-point (CDP) processed data of high standard. In general, Taranaki Basin produces seismic data of high quality. The only areas in the basin where data quality is a limiting factor in regional interpretation are onshore, where Recent volcaniclastic cover inhibits acquisition of quality data, and off the edge of the continental shelf, where generally only single fold, and poor quality, data are available. Examples of the general quality of regional CDP data can be seen on sheet 14 , which is a montage of sample seismic lines from various parts of the basin.

The seismic reflection data were tied to petroleum exploration wells throughout the basin. Offshore, most wells available on open-file were incorporated into this study, because of the wide spacing between wells. Onshore, where a number of closely spaced wells are available, only those wells considered necessary for regional ties were used. A total of 47 wells were used. Of these, 26 were from the offshore region, 20 were from the Taranaki Peninsula, and one was from the northernmost end of the South Island. The wells referenced as a part of this interpretation are detailed in Appendix 3, and their locations shown on Sheet 13. Well completion reports for the these wells are on file with the New Zealand Geological Survey.

From well completion reports, or more recent data if available, the depth and reflection time to each of the seismic horizons listed above was determined. These data were then used as control points during the systematic interpretation of the grid of seismic lines. In most wells, the seismic reflection horizons correspond to significant geologic horizons. However, it is important to remember that the paleontologically-determined series boundary is what the seismic reflection data is tied to and not necessarily a geologically significant boundary.

The depth and reflection times determined from the wells were also used to develop a depth-conversion relationship for the basin. The depth conversion method used is discussed in detail in Section 5. 
South Wanganui Basin is included on a few of the maps. Because this small basin is a late Neogene feature, and is believed to contain no pre-Pliocene sediment (Anderton 1981), it appears only on the basement and late Neogene maps. Seismic reflection data from this basin were not interpreted as a part of the present study. Two-way-time maps for South Wanganui Basin were developed at the New Zealand Geological Survey several years ago and were the basis for the previously published study of this basin (Anderton 1981). For the present study the two-way-reflection-time maps prepared by Anderton, and on file at the New Zealand Geological Survey, were digitized, converted to depth and thickness, and merged with the results of the Taranaki Basin mapping. The depth conversion method used for the South Wanganui Basin portion of the present maps is also discussed in Section 5.

\section{SECTION 4: “DATA INTERPRETATION}

The interpretation of seismic reflection data for this study was completed over a period of about four years, beginning in late 1984. The interpretation was begun on the Western Platform, where the structure is simple and the stratigraphy straightforward, then extended into the Taranaki Graben where the structure is complete. The last portion, interpreted in early 1989, was the onshore Taranaki Peninsula area.

The method used in interpretation was to tie reflectory or key seismic lines to wells located on those lines. The reflectors were then interpreted from the well locations using a loop-tie method which required each line to be continuously tied back into previously interpreted areas. Line-ties between adjacent wells were generally very good. All major reflectors were carried through the seismic profile grid together, and additional intermediate reflectors were interpreted in local areas to clarify structure or stratigraphy. The colour scheme used to depict horizons is similar to that used by Shell, BP and Todd for Taranaki Basin, and followed by numerous other companies. That colour scheme is as follows:

1. Seismic Basement: red.

2. Near top Cretaceous: purple.

3. Near top Eocene: blue.

4. Near top Miocene: yellow 
5. Seafloor: green

Seismic basement is here defined as that geologic horizon below which coherent seismic energy is not returned to the surface. This can be a very difficult horizon to identify, especially in regions where basement is very deep (greater than 6 seconds in some mapped areas) or where some sub-coherent energy is being returned from below the geologic basement surface.

Throughout the region covered by this study, seismic basement is believed to correspond with geologic basement. Geologic basement is the geologic surface below which only highly folded and disturbed sedimentary rocks and rocks of non-sedimentary origin are found. Well ties indicate that seismic basement is indeed the bottom of the sedimentary sequence, except possibly at the Tasman-1 drill site, where seismic basement may correspond to an indurated breccia of uncertain thickness and age. Nathan and others (1986) correlated these rocks with the Hawks Crag Breccia of middle Cretaceous age, but admit this correlation is uncertain. Elsewhere in Taranaki, rocks of middle Cretaceous age lie above the basement reflector. Whatever these rocks at Tasman-1 are, they can be considered as economic basement.

The top Cretaceous (Mata-Dannevirke boundary) reflector is not present everywhere in the study area. Sediments of Cretaceous age occur in deep grabens associated with the earliest rift history of the basin (Thrasher 1989), and as a thin transgressive sequence over much of the Western Platform. Elsewhere, these sediments are not present generally due to non-deposition over high-standing basement areas. The seismic signature of the top Cretaceous reflector changes regionally, but is usually marked by a significant change in the reflection character of the sequence. Typically the reflector marks the onset of a major regional transgression.

The top Eocene (Amold-Landon boundary) reflector is, over much of the basin, the best known reflector in New Zealand. On the Western Platform this reflector represents the base of a hard early-Oligocene limestone, which overlies mudstone of lower seismic velocity. This velocity inversion creates a high amplitude, phase-inverted reflector that is easily recognized. 
Within the Southern Zone this limestone may be time transgressive, with deposition beginning later in the Oligocene in some places. Fortunately the sedimentation rate was sufficiently low that the high-amplitude base-limestone reflector can be interpreted as representing top Eocene with minimal error.

Throughout much of the Taranaki Graben and onshore Taranaki Peninsula regions the early-Oligocene limestone is missing and often a late-Oligocene to early-Miocene limestone (the Tikorangi Limestone) is present. This situation has often caused confusion, because in these regions the base of the Tikorangi Limestone is generally used as a seismic marker, usually coloured blue, and sometimes correlated with the offshore base-Oligocene seismic marker. For this study, wells throughout the basin have been used to determine the reflection time to top Eocene, and that surface has been seismically traced, irrespective of the presence of limestone in the sequence.

In the easternmost portions of the basin a significant geologic discontinuity occurs at the base of the Oligocene Matapo Sandstone, up to $100 \mathrm{~m}$ above the top of the Eocene. Over some parts of the Taranaki Peninsula it is this discontinuity that generates the seismic reflector nearest to the top Eocene horizon, and has hence been followed on seismic reflection data. The error introduced by following the base of the Matapo Sandstone is generally smaller than the contour interval of the maps, and of the same magnitude as other sources of potential error.

The top Miocene (Taranaki-Wanganui boundary) horizon is generally marked by a significant unconformity. Throughout the Southern Zone and much of the Taranaki Graben this unconformity is angular, and easily recognized on seismic reflection data. Over much of the Western Platform the unconformity is disconformable, and is marked by the deposition of a marl which creates a distinctive seismic reflector. Between these two regions this horizon is a normal sedimentary contact in a progradational sequence. Because this reflector represents a highly variable, and usually unconformable surface, the amount of time represented by the missing portions of the sequence is also highly variable. In all cases, this surface represents a contact between sediments older than Wanganui Series and overlying Wanganui Series strata. 
The seafloor was interpreted on all offshore sections, and loop-tied like any other horizon. This was done to make depth conversion easier, and so that an isopach map of the post-Miocene sedimentary sequence could be constructed. Onshore, the seismic datum used is sea level, and no rocks above sea level are considered in this study. Rocks above sea level on the Taranaki Peninsula are mostly Pleistocene volcanics associated with Mt. Egmont (Taranaki).

Once a series of seismic lines was interpreted for the horizons discussed above, the lines were computer digitized. Most lines were digitized at about one kilometre intervals. The digitized points were then merged with navigation data to generate a file of reflection times at specific geographic points (in latitude-longitude coordinates). These line-files have been incorporated into a database containing digitized reflection times for the entire basin.

From this basin-wide database, maps with posted reflection-time values were computer plotted for contouring. Contouring was done by hand at a scale of 1:200,000. All reflection-time maps were contoured at a standard contour interval of $50 \mathrm{msec}$. The 1:200,000 contoured sheets were then digitized for incorporation into a computer cartographic system. The final series of maps is presented at a scale of 1:500,000.

\section{SECTION 5: DEPTH CONVERSION}

Before the posting and contouring steps could be accomplished for those maps representing true thickness or depth (isopach and structure maps), the seismic reflection time values had to be converted into linear measurement values (depth conversion).

The method used for depth conversion in this study is that suggested for the Western Platform by Thrasher (1988), with modifications to allow for its use throughout the basin. Well data were used to determine best-fit equations for the computation of the thickness of each of the four seismic reflection units, based on the interval-travel-time within that unit. These thickness values were then summed to obtain structure values for each of the seismic mapping 
horizons. Although sufficient for regional basin mapping, this technique is probably not accurate enough for mapping individual hydrocarbon prospects.

Two sets of depth conversion equations were developed; one for the offshore region, and one for the Taranaki Peninsula. For the offshore equations, wells which had good definition of one or more of the seismic reflection units were used to obtain values of the thickness and interval-travel-time for the units.

Using these data, curves of interval-travel-time versus thickness have been constructed for each seismic unit.

Figure 3 is the thickness-versus-time curve for the post-Miocene seismic unit. The solid line is the curve fit to the data using a multiple regression on " $t$ " and " 2 " (where " $t$ " = interval-travel-time). The curve shows increasing thickness with increasing interval-travel-time. The increasing slope of the best-fit line shows that the interval velocity of the unit is increasing with increasing thickness. This increasing velocity with thickness is caused by the normal compaction of the sediments as the unit thickens. From this curve we can conclude that, for the offshore, lateral variations of the seismic velocity within this unit are predictable, and caused mostly by lateral changes in the thickness of the unit.

The multiple regression gives us a formula for computing the thickness of this unit based on the travel-time data available from the digitized seismic sections. The interval-travel-time within the post-Miocene seismic unit is the travel-time to the top-Miocene reflector, minus the travel-time to the seafloor.

The thickness versus interval-travel-time curve for the Oligocene-Miocene seismic unit is shown on Figure 4. The scatter on this graph is a bit greater than that for the post-Miocene unit, but a statistical fit to a binomial equation is still quite good. Thickness is predictable from the interval-travel-time in the unit and, like the post-Miocene, lateral velocity variation in the unit appears to be caused mostly by lateral variations in the thickness of the unit. The data-point scatter is probably due to lateral variations in lithology within the sequence. The statistically derived equation can be used to compute the thickness of this unit based solely on 


\section{Pliocene-Pleistocene, Offshore}

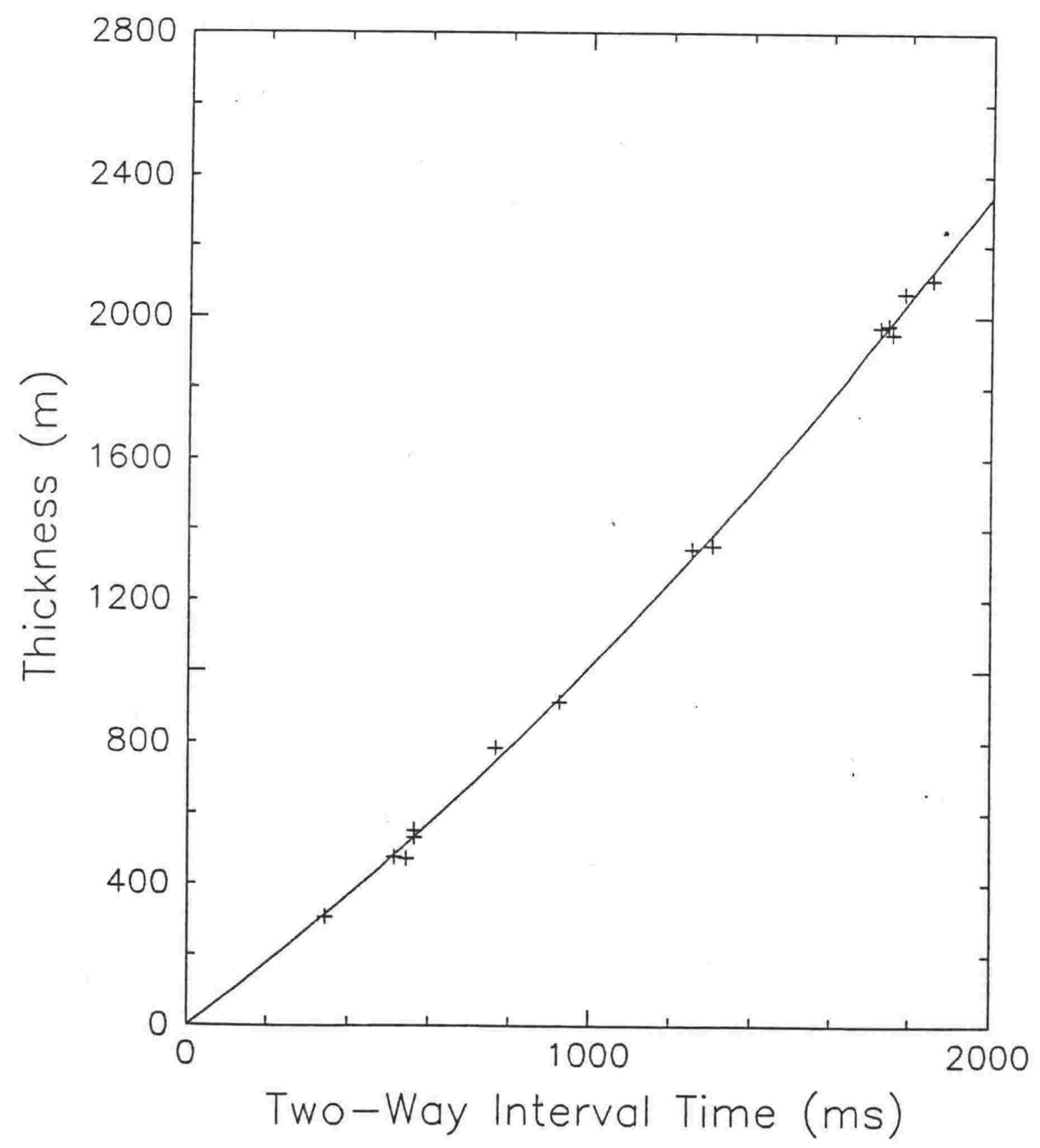

Figure 3. Thickness versus interval-travel-time for the post-Miocene (Wanganui) seismic unit offshore.

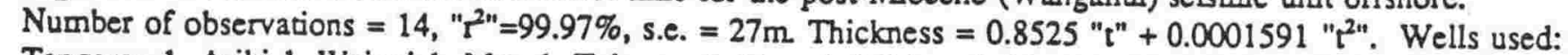
Tangaroa-1, Ariki-1, Wainui-1, Moa-1, Taimana-1, Tane-1, Witiora-1, Maui-1, Maui-2, Maui3, Maui-4, Kiwa-1, Moki-1, Kongahu-1. 


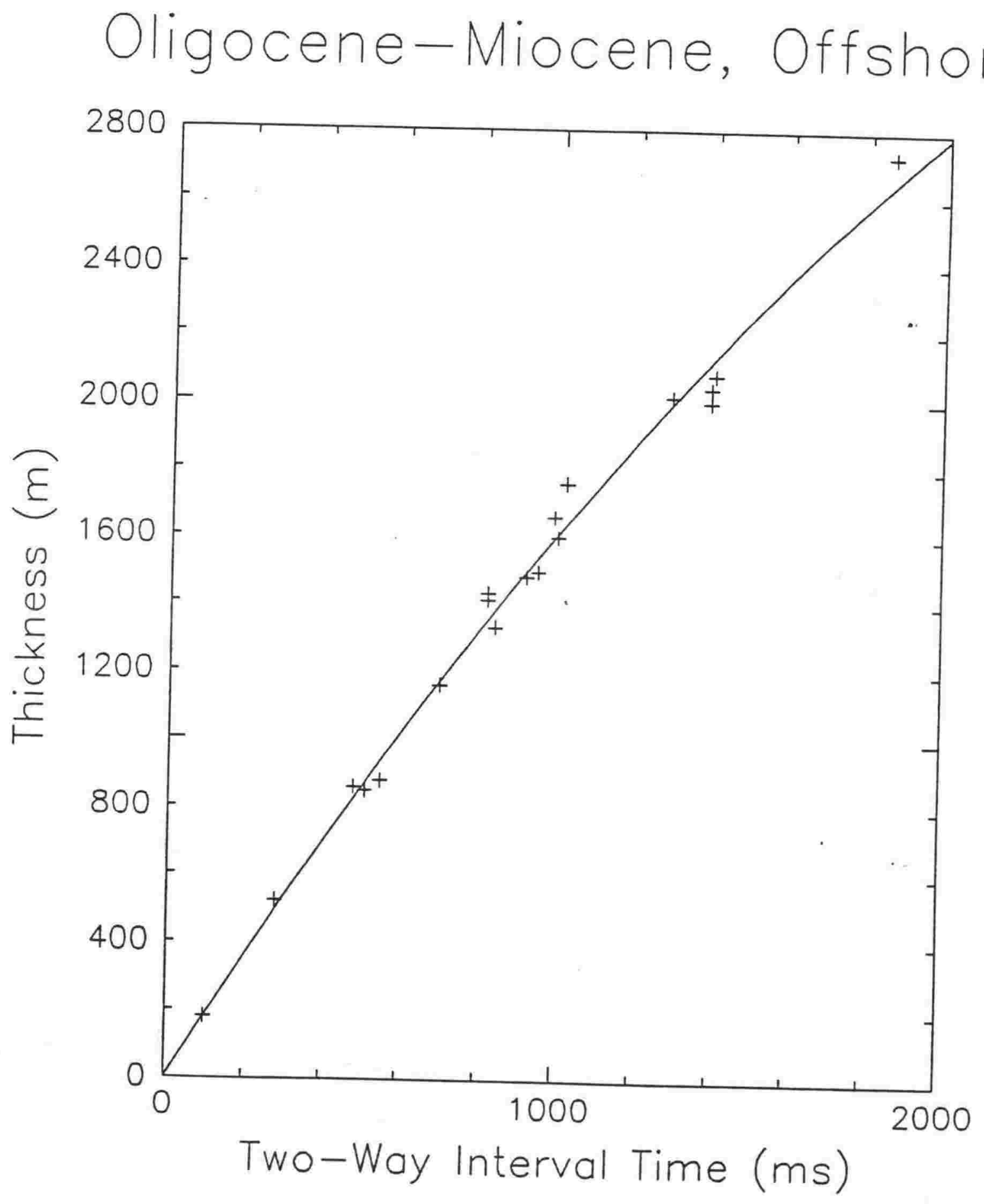

Figure 4. Thickness versus interval-travel-time for the Oligocene-Miocene (Landon, Pareora, Southland and

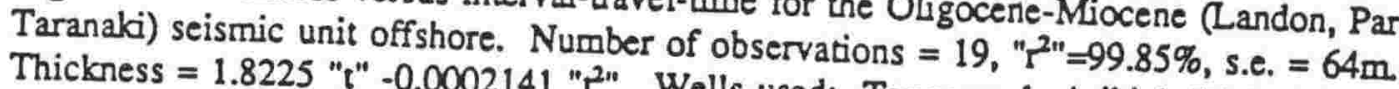
Tane-1, Witiora-1, Maui-1, Maui-2, Maui3, Maui-4, Kangaroa-1, Ariki-1, Wainui-1, Moa-1, Taimana-1, North Tasman-1, Fresne-1, Surville-1. 
the interval-travel-time within the unit. Note that this curve is convex upward, in contrast to a normal compaction trend. Thrasher (1988) suggested this velocity trend is caused by the high-velocity calcareous sediments at the base of the sequence becoming progressively more significant in determining the interval velocity as the unit becomes thinner.

Figure 5 is the thickness-versus-time curve for the Paleocene-Eocene seismic unit. This unit is generally thin, with no well penetrating more than 1200 metres of Paleocene to Eocene sediment. To construct this curve, only those wells which penetrated the entire sequence were used. A large number of wells penetrated only the uppermost parts of the this unit before reaching their total depth, and were not used. The scatter in this graph is considerable. Thrasher (1988) showed this scatter to be the result of lateral variations in the lithology and overburden history of this unit. A linear regression to the data points shown on Figure 5 gives a seismic velocity of 3400 metres/second for this interval, and this velocity has been used in calculating the thickness of this unit.

Figure 6 illustrates the thickness-versus-time data for sediments of Cretaceous age in the basin. Only ten open-file wells have reached Cretaceous sediments. Six of these wells have reached basement through the Cretaceous, and they are all in regions of anomalously thin Cretaceous sediment. Because of the low number of sample points, all ten wells have been included in Figure 6. A linear regression to these data points gives a seismic velocity of 4000 metres/second for this interval, and this velocity has been used to compute the thickness of Cretaceous sediments.

On the Taranaki Peninsula, no open-file wells have penetrated the complete Paleocene-Eocene sequence, or recovered Cretaceous aged sediment. Because of this lack of data for the older portions of the stratigraphic column, the equations determined for the offshore wells have been used to compute the thickness of the Cretaceous and Paleocene-Eocene seismic units under the peninsula.

For the younger post-Miocene and Oligocene-Miocene units the thickness and interval-travel-time graphs have been separately constructed (Figures 7 and 8). For the upper 


\section{Paleocene-Eocene}

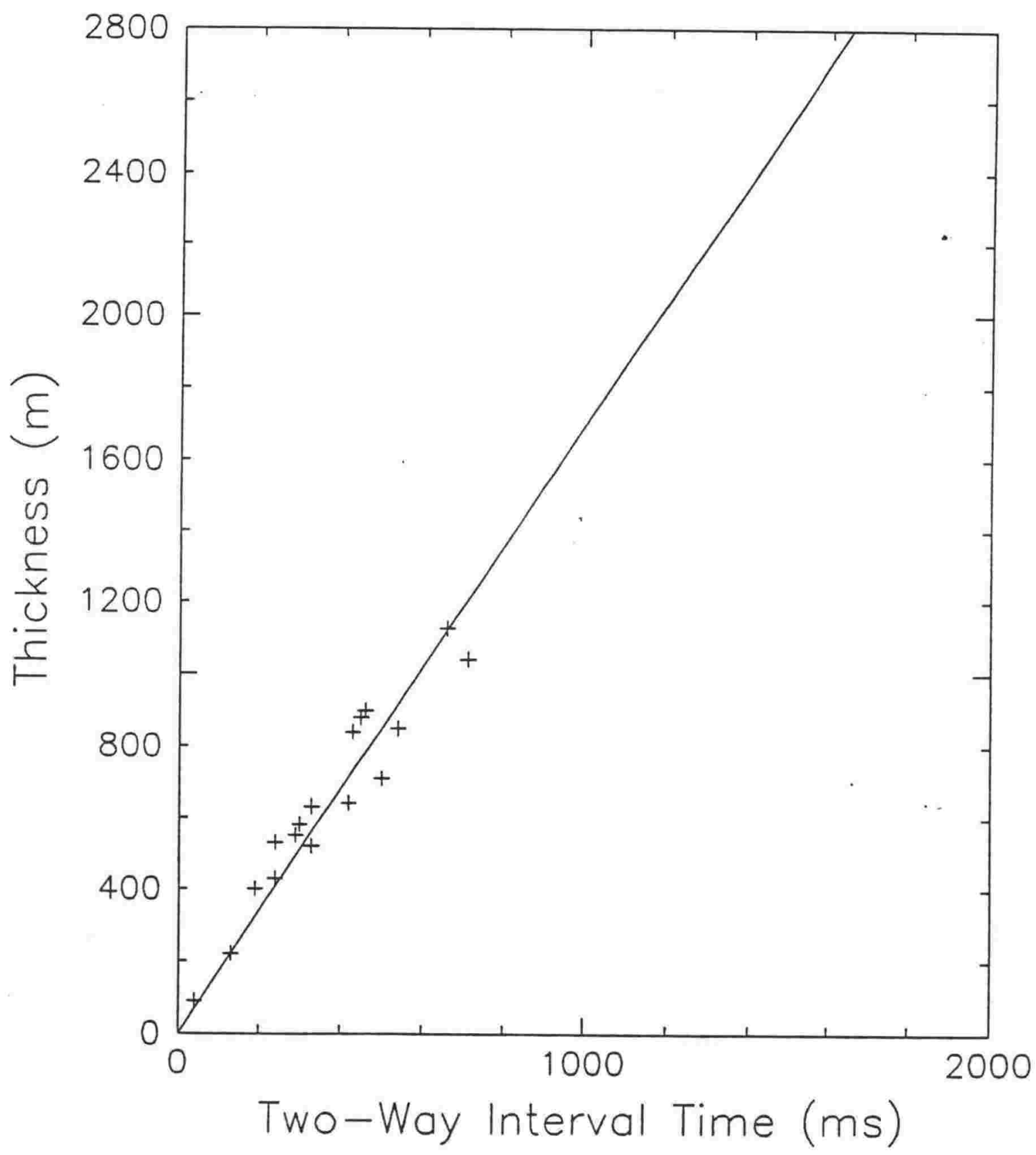

Figure 5. Thickness versus interval-travel-time for the Paleocene-Eocene (Dannevirke-Amold) seismic unit. Number of observations $=17, " \mathrm{r}^{2} "=98.39 \%$, s.e. $=91 \mathrm{~m}$. Thickness $=1.6983$ " $\mathrm{t} "$. Wells used: Tangaroa- 1 , Ariki-1, Wainui-1, Moa-1, Tane-1, Witiora-1, Maui-1, Maui-2, Maui-4, Kiwa-1, Mokd-1, Kongahu-1, Tasman-1, North Tasman-1, Fresne-1, Cook-1, Surville-1. 


\section{Cretaceous}

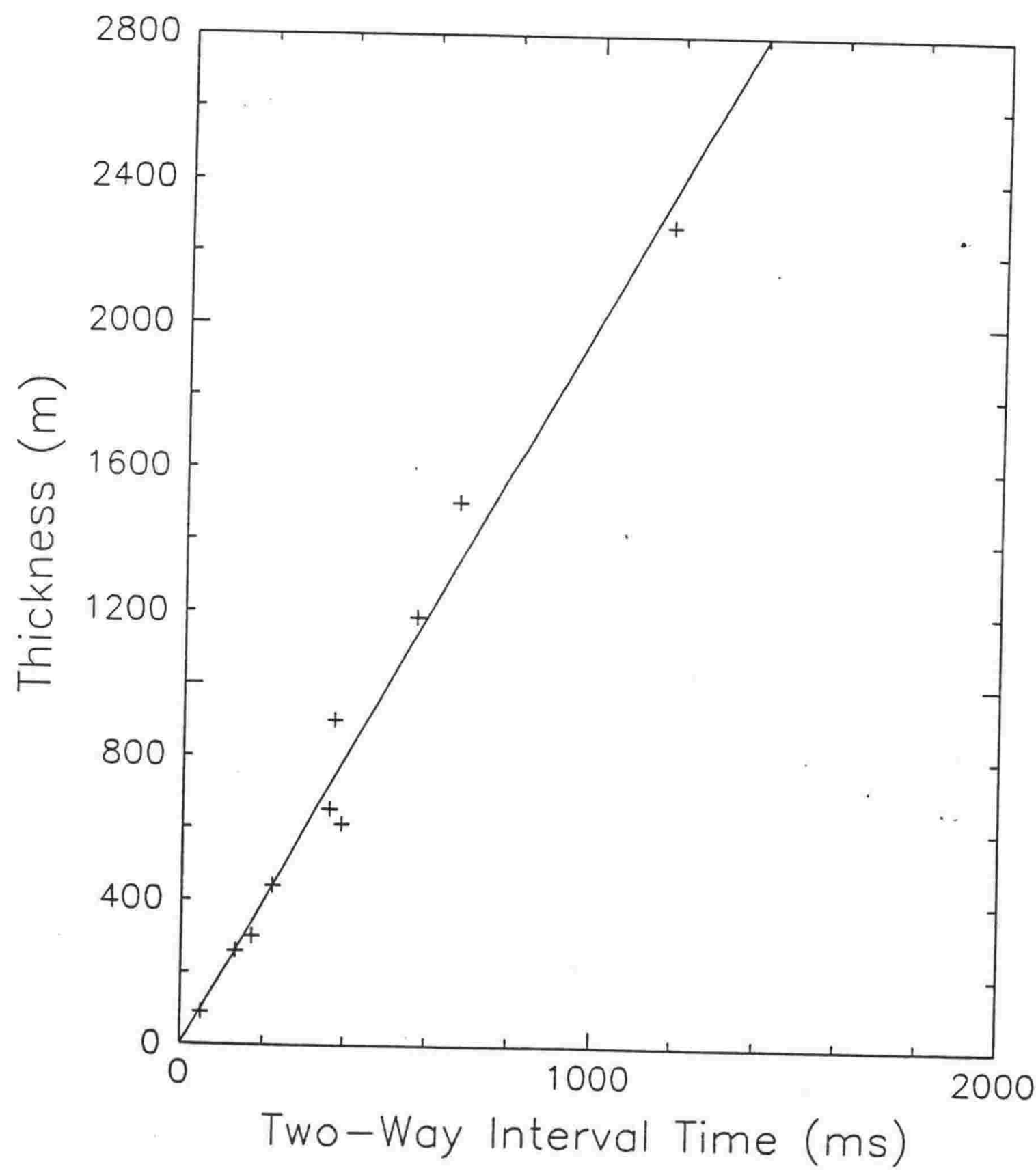

Figure 6. Thickness versus interval-travel-ime for the Cretaceous (Clarence, Raukumara and Mata) seismic
unit. Number of observans

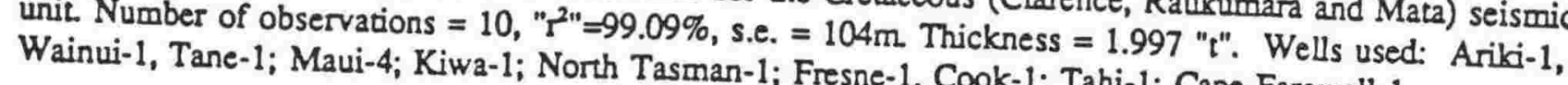


interval, the datum used as an upper surface for constructing the graph is sea level. 242 Because the post-Miocene interval is not present over much of the prospective eastern side of the Peninsula, and because in many other wells the Miocene-Pliocene boundary was not determined in the well stratigraphy, Figure 7 has only 5 data points. Those points give a linear regression velocity of 2550 metres/second, which has been used to compute the thickness of this unit.

The Oligocene-Miocene seismic unit is significantly thicker in wells drilled on the Peninsula than in offshore wells (almost 4000 metres versus 2800 metres offshore). Figure 8 therefore has different scales from the other graphs. This greater thickness also means the velocity is much higher, due to normal compaction of a considerable thickness of sediment. Although Figure 8 indicates considerable scatter, a linear-regression-derived interval velocity of 3370 metres/second was used to calculate the thickness of the unit under the peninsula.

The depths to each of the seismic horizons were computed by summing the thickness of each of the units overlying the horizon. If offshore, the thickness of the water column was calculated at 1500 metres/second and added to the sedimentary thicknesses. For example, the depth to seismic basement at any digitized seismic location offshore is:

\section{$\mathrm{BDM}=\mathrm{H} 2 \mathrm{O}+\mathrm{PPM}+\mathrm{OMM}+\mathrm{PEM}+\mathrm{CM}$}

Where: $\mathrm{BDM}=$ Basement depth in metres.

$\mathrm{H} 2 \mathrm{O}=$ Water depth in metres.

PPM=Thickness of post-Miocene in metres.

$\mathrm{OMM}=$ Thickness of Oligocene-Miocene in metres.

PEM=Thickness of Paleocene-Eocene in metres.

$\mathrm{CM}=$ Thickness of Cretaceous in metres.

Each of the thickness values above having been calculated from the interval-reflection-times for the unit using the equations determined from the data illustrated in figures 3 through 6 . 

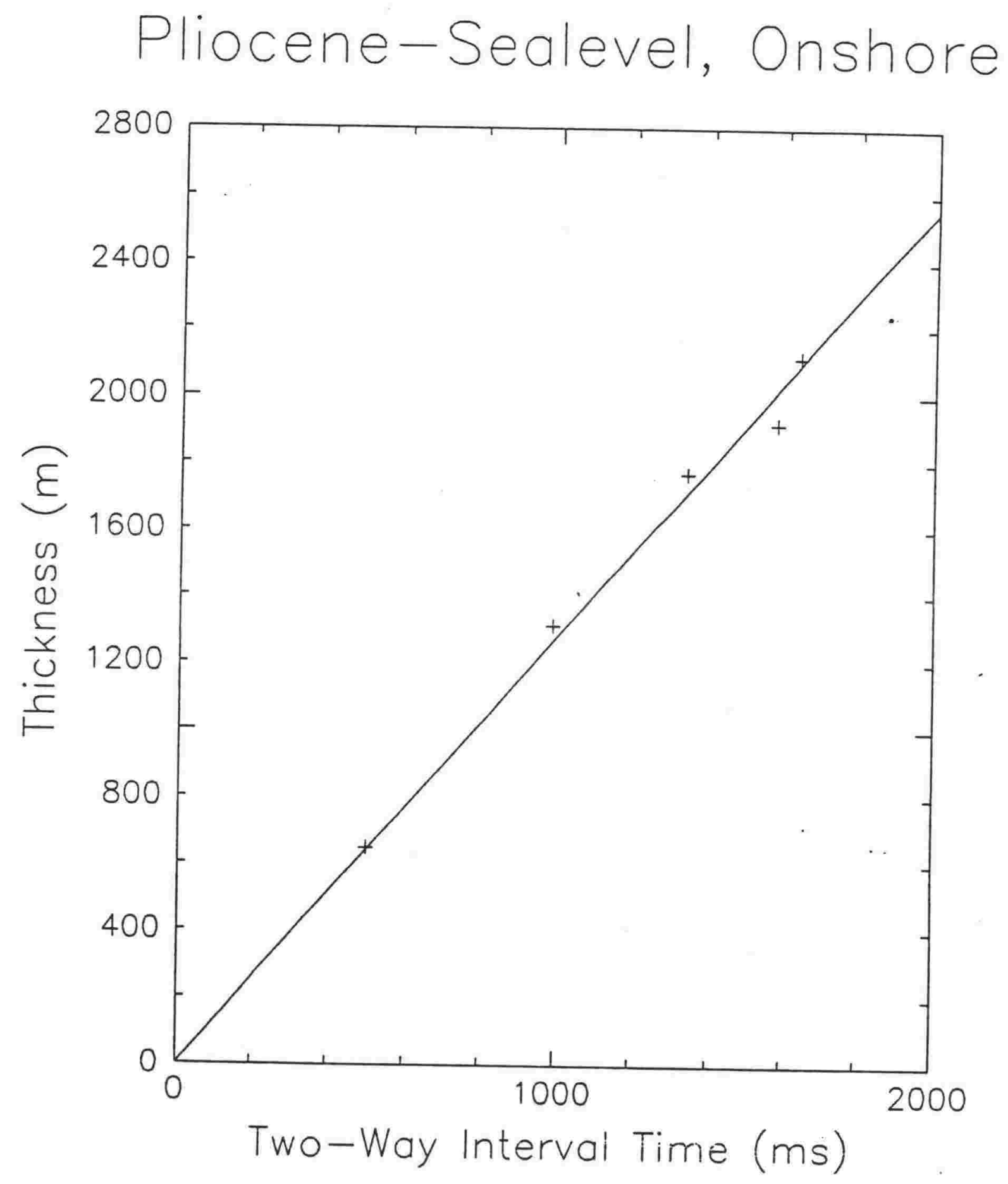

Figure 7. Thickness versus interval-travel-time for the post-Miocene (Wanganui) seismic unit onshore. Number of observations $=5$, "2" $\mathrm{r}^{2}=99.88 \%$, s.e. $=63 \mathrm{~m}$. Thickness $=1.277 " \mathrm{t} "$. Wells used: Tipoka-1, Te
Kiri-1, Kapuni-2, Cape Egmont-1, Waihapa-1. 


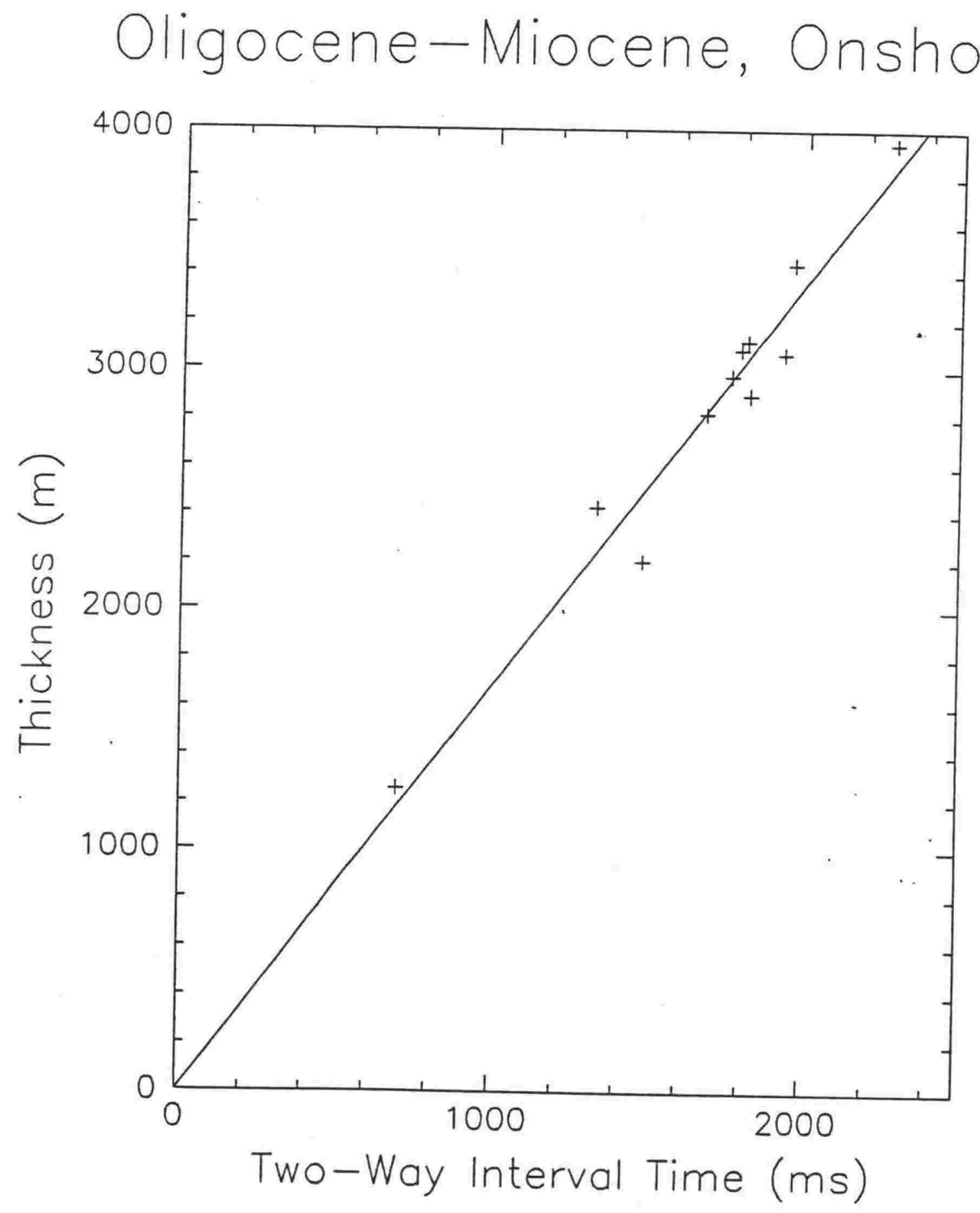

Figure 8. Thickness versus interval-travel-time for the Oligocene-Miocene (Landon, Pareora, Southland and Taranaki) seismic unit onshore. Number of observations $=11, " 2^{2 "}=99.76 \%$, s.e. $=151 \mathrm{~m}$ Thickness $=1.684$ " $t$ ". Wells used: Te Kiri-1, Kapuni-2, Kaimiro-1, Ngatoro-1, Stratford-1, Onaero-1,
McKee-1, Tarik-1, Wharehuia-1, Toko-1, Waihapa-1. 
Calculated isopach and structure values were computer plotted at a scale of 1:200,000 and hand contoured. Because the values for data collected from the Taranaki Peninsula were computed with slightly different velocity models, some smoothing of contours crossing the coastline was required. Generally this was a minor problem, except immediately north of the peninsula, where the Oligocene-Miocene unit is very thick (over $4 \mathrm{~km}$ ). The offshore velocity model tends to underestimate the thickness in this situation and hence the mis-tie between the offshore and onshore computed thicknesses became significant (up to a few hundred metres). In this region the contours for this unit were smoothed and adjusted to increase the offșhore thicknesses north to the Turi Fault Zone.

For the Wanganui Basin portion of the map area a slightly different depth conversion strategy was used. In Anderton's 1981 study of the basin, he presented a generalised time-depth curve for the basin, based on seismic-reflection-derived velocities (Anderton 1981, Figure 16). That curve was used to re-contour Anderton's reflection-time maps as structural depths. Because the water depth over the basin is fairly small (generally less than 100 metres), the isopach map was constructed by subtracting water depth from structural depth. Water depth was determined from the New Zealand Oceanographic Institute 1:200,000 Coastal Chart Series (Brodie 1969; Mitchell and Lewis 1980).

\section{SECTION 6: PROBLEM AREAS}

Interpretative maps are always subject to errors (such as data interpretation errors, depth conversion errors, and contouring errors). While some generalization, simplification, and error, is accepted in a regional project of this magnitude, a few geographic areas of the maps present special problems which need to be mentioned.

Some of these problems have already been discussed, such as the need to smooth contours that crossed the Taranaki Peninsula coastline. This mismatch across the coastline is caused by the different depth conversion models used for the onshore data versus the offshore data. The only area where this causes significant problems is immediately north of the peninsula, where the thickness of the Oligocene-Miocene sequence is probably underestimated by a few 
hundred metres. In this region the thicknesses indicated by the onshore data were extended north up to twenty kilometres to the Turi Fault Zone, using trends from the reflection-time maps.

The difficulties involved in determining the top-Eocene horizon on seismic reflection data were discussed in Section 4. Although of geologic significance, and representing up to 5 million years, the problems associated with determining the difference between top Eocene and the base of the Matapo Sandstone only account for a few tens of metres of stratigraphic thickness, and are not considered a significant source of error on the maps involving the top Eocene horizon.

An area where significant error is suspected is along the eastem edge of the basin under the Taranaki Peninsula. In this area the subsurface geology is complicated by numerous reverse faults, referred to as the Tarata Thrust Zone. These reverse faults control several hydrocarbon-bearing structures, including the McKee and Waihapa fields. Because many of these structures are small in geographic extent, they are difficult to map without a very dense grid of seismic data. Data quality in this region is also very poor, leading to possible interpretation errors. The structural complexity, poor data quality, and small amount of data interpreted over this trend all combine to cast doubt over the accuracy of the maps in this region. If detailed information about the structures along the Tarata Thrist Trend is required, the Petrocorp relinquishment report for licence PPL 38034 (Andrews and others 1987), or reports for the individual structures along this trend, should be referenced.

The post-Miocene faulting along the western side of the peninsula, when combined with the poor data quality, causes complications in interpretation and contouring. Again, this zone may not be imaged very well, and caution is advisable. Nearby, very little data are available within the boundaries of Egmont National Park. The maps have been constructed by contouring across the park, but the subsurface structure portrayed is only an estimate.

Throughout the peninsula there is a problem in tying wells with seismic data at the top-Miocene horizon. The paleontological dating reported in well completion reports at this 
horizon is in poor agreement with the seismic data. The maps illustrate a surface whickutdes with most of the onshore exploration wells used, but is not in agreement with Te Kiri-1 or Stratford-1. Using seismic reflection data it may be possible to improve the stratigraphic interpretations of many of the onshore wells at this level.

The better seismic data offshore leads to greater confidence in the interpretation. The greatest source of error offshore is likely to be mis-interpretation of reflectors due to inaccurate well control. These inaccuracies are commonly caused by paleontological problems in dating the rock sequences, and technical problems with sampling or logging of the wells. The largest known possible error in the maps caused by uncertainty in the dating is in the vicinity of Tane-1. These maps are based on the original well completion report, which indicated "top Pakawau" was at about 3640 metres, at the top of a terrestrial coal measure sequence. A recent reinterpretation of the well column (King 1988) indicates that top Cretaceous may be at the top of a previously undated marine sequence about 150 metres higher. If King's interpretation is correct, then the top Cretaceous reflector may be mapped up to 300 metres below the actual top Cretaceous within a zone up to a few tens of kilometres around the Tane-1 well site.

Another problem in the offshore portions of the study area is the difficulty interpreting the top Cretaceous and seismic basement reflectors in areas where the sediment cover is very thick or data quality is poor. In the northem end of the region, several deep Cretaceous grabens, and the younger North Taranaki Graben, cause basement depths to exceed six kilometres. Within this area identification of both top Cretaceous and basement is difficult. Identification of these horizons is also difficult under the Taranaki Peninsula. While the presented maps are believed to be a close approximation to the configuration of these surfaces, users should be aware of the potential for significant errors.

Within the North Taranaki Graben, top Cretaceous is mapped on a seismic reflector separating a less-reflective, probably marine, sequence from an underlying band of stronger reflectors. If significant thicknesses of marine sediments were deposited in this area before the end of the Cretaceous, then the mapped horizon may be lower than the Cretaceous-Tertiary boundary. 
In many places in the basin, sub-basement reflectors have been imaged on seismic data. Most of these can be accounted for as off-line reflectors, such as fault scarps, or as discontinuities within basement. Some may be indicating that the reflector tied throughout the region as basement may, in places, not be the base of the sedimentary sequence, although this is not considered to be very likely. However, some seismic profiles suggest that the northern portion of the Westem Platform, in the northwest comer of the maps, may contain Cretaceous-aged sedimentary centres not imaged on these maps. If present, the extent and thickness of these sediments cannot be accurately ascertained until more detailed data of better quality is available.

The sparsity of data, and the poor quality of available data, over areas off the continental shelf means that only low confidence can be placed on the interpretation in the northwest corner of the mapped region. The available data is sufficient to portray the connection between Taranaki Basin and the New Caledonia Basin along the northern edge of the maps. Other areas where data sparsity and quality conspire to prevent accurate imaging of the subsurface include the region north, and immediately west, of D'Urville Island. To the west of the island is a small basin, called the Greville Basin by Nathan and others (1986), and presumed by them to contain sediments of undifferentiated Cretaceous to Paleocene age. This basin lies under the top-Eocene reflector, but a more accurate age than pre- Oligocene can not be established with the presently available data. The basin is roughly on trend with the Paleocene-Eocene basin underlying the Kapuni and Kupe structures, and has a similar thickness of sediments. Because of this on-trend relationship, and the inability to infer the presence of Cretaceous sediments within the Greville Basin, either on geologic or seismic evidence, the entire fill of the basin has been included within the Paleocene-Eocene sequence in this interpretation. The presence of Cretaceous sediments within this small basin is quite possible, however, as Cretaceous sediments are present under the Paleocene-Eocene sediments in the Kapuni to Kupe region mentioned above.

Structural complexity and the presence of Miocene volcanics combine to make the North Taranaki Graben a difficult region to understand, and one prone to interpretation errors. In this region, the history of movement along the Turi Fault Zone is difficult to determine. This 
seismic interpretation has indicated that only dip-slip, post-Oligocene motion has occuaret along this trend, and the isopach maps have been contoured accordingly.

Lastly, the velocity models used to depth convert this data must be considered a major source of error. This is especially true of the Paleogene and Cretaceous sequences. The small number of measurements, and their lack of geographic diversity, for the lower portions of the sedimentary sequence means that the depth and thicknesses portrayed on the maps can only be considered a rough approximation of the true geometry of the basin.

The authors would appreciate being notified of any errors or misinterpretations which users of these maps identify, bearing in mind that they are regional maps, and not intended to accurately portray local structure.

\section{SECTION 7: SPECIAL PRODUCTS AVAILABLE}

Numerous special products associated with the compilation of this set of maps are available to map purchasers. Any requests for information, price or availability of these products should be addressed to:

The Chief Petroleum Geologist

New Zealand Geological Survey

P.O. Box 30-368

Lower Hutt

New Zealand Fax: (04) 691479

The following are some of the special products which are available:

1. Digital seismic navigation for the data used, as well as other Taranaki Basin and New Zealand data is available in UKOOA/P1-84 format.

2. Catalogues of seismic reflection data are available for Taranaki Basin, and other N.Z. regions. The catalogues list basic acquisition and processing parameters of the data.

3. Shot-point base maps of any region can be computer generated at a variety of different scales and projections. 
4. All or parts of any of the contour maps included with this map set can be computer plotted at a variety of scales and projections.

5. Maps of the digital values upon which these maps are based can be posted, ready for contouring, at a variety of scales and projections.

6. Additional digital values based on the digitized seismic profiles can be calculated and posted (such as isopach or structure maps based on purchaser-supplied velocity models).

7. Digital versions of the contour maps can be produced as VAX-compatible computer files.

8. The database of digitized seismic sections can be obtained as VAX-compatible computer files.

9. Seismic sections or well completion reports on open-file can be purchased.

10. Seismic field tapes may be obtained for reprocessing.

11. Details on the computer routines used for data manipulation can be supplied. 
Anderton, P.W. 1981: Structure and evolution of the South Wanganui Basin, New Zealand. NZ. Journal of Geology and Geophysics, Vol. 24: 39-63.

Andrews, P.B.; Bulte, G.A.; Plume, R.W. 1987: Petroleum prospecting licence 38034 representative regional maps and interpreted seismic lines. New Zealand Geological Survey open-file petroleum report 1263.

Brodie, J.W. 1969: Patea Bathymetry. New Zealand Oceanographic Institute Chart, Coastal Series, 1:200 000.

Edwards, A.R.; Homibrook, N.deB.; Raine, J.I.; Scott, G.H.; Stevens, G.R.; Strong C.P.; Wilson G.J. 1988: A New Zealand Cretaceous-Cenozoic geological time scale. New Zealand Geological Survey Record 35: 135-149.

King, P.R. 1988: Well summary sheets, offshore Taranaki. New Zealand Geological Survey Report G127.

King, P.R.; Robinson, P.H. 1988: An overview of Taranaki region geology, New Zealand. Energy Exploration and Exploitation, Vol. 6, No. 3: 213-232.

King, P.R.; Thrasher, G.T. (in prep.): Post-Eocene development of the Taranaki Basin, New Zealand: convergent overprint of a passive margin. Submitted to: American association of petroleum geologists, memiors.

Knox, G.J. 1982: Taranaki Basin, structural style and tectonic setting. NZ. Journal of Geology and Geophysics, Vol.25: 125-140.

Mitchell, J.S.; Lewis, K.B. 1980: Cook Strait Bathymetry, 2nd Edition. New Zealand Oceanographic Institute Chart, Coastal Series, 1:200 000. 
Nathan, S.; Anderson, H.J.; Cook, R.A.; Herzer, R.H.; Hoskins, R.H.; Raine, J.I.; Smate, D. 1986: Cretaceous and Cenozoic sedimentary basins of the West Coast region, South Island, New Zealand. New Zealand Geological Survey basin studies 1.

Pilaar, W.F.H.; Wakefield, L.L. 1978: Structural and stratigraphic evolution of the Taranaki Basin, offshore North Island, New Zealand. The APEA journal, Vol. 10: 93-101.

Thrasher, G.P. 1988: The interpretation of seismic reflection data from the Western Platform region of Taranaki Basin. Energy exploration and exploitation, Vol. 6, No. 2: 136-150.

Thrasher, G.P. 1989: Tectonic control of early-rift (Cretaceous) sedimentation, Taranaki Basin, New Zealand. Geological Society of Australia abstracts, Vol. 24: 151-152. 
1: Reflection-time isochron on top Miocene.

2: Reflection-time isochron on top Eocene.

3: Reflection-time isochron on top Cretaceous.

4: Reflection-time isochron on seismic basement.

5: Isopach of post-Miocene sediments.

6: Isopach of Oligocene-Miocene sediments.

7: Isopach of Paleocene-Eocene sediments.

8: Isopach of Cretaceous sediments.

9: Structural contours on top Miocene.

10: Structural contours on top Eocene.

11: Structural contours on top Cretaceous.

12: Structural contours on seismic basement.

13: Well and seismic profile location map.

14: Sample seismic profiles. 
APPENDIX 2. SEISMIC LINE STATISTICS

Offshore Seismic Reflection Profiles used in this study

\begin{tabular}{|c|c|c|c|c|c|c|c|}
\hline LINENAME & MINLAT & MAXLAT & MINLONG & MAXIONG & MNNTT & MAXPT & LEN(KM) \\
\hline $101 \mathrm{~A}$ & S40.46772 & S40.61639 & E174.01917 & E174.10513 & 10 & 110 & 18.1 \\
\hline 17 & S40.35343 & S40.36403 & E171.53613 & E172.03177 & 0 & 849 & 42.1 \\
\hline $19 B$ & S40.09741 & S40.37182 & E171.58702 & E171.60510 & 1 & 601 & 30.7 \\
\hline 21 & S40.09780 & S40.36871 & E171.68362 & E171.69255 & 0 & 601 & 30.1 \\
\hline 24 & S40.09385 & S40.36847 & E171.77966 & E171.79384 & 1 & 599 & 30.5 \\
\hline 27 & $S 40.09602$ & S40.36882 & E171.97086 & E171.98067 & 1 & 600 & 30.4 \\
\hline 28 & S40.18249 & S40.26417 & E170.94853 & E171.25935 & 0 & 550 & 27.9 \\
\hline $72-115$ & S38.57170 & S39.66940 & E170.88651 & E171.10699 & 200 & 1200 & 123.6 \\
\hline $72-164$ & S38.32260 & S38.55400 & E172.89011 & E173.65649 & 0 & 500 & 71.6 \\
\hline $72-165$ & S38.35720 & S38.69020 & E172.93311 & E173.44920 & 530 & 930 & 58.3 \\
\hline $72-168$ & S39.01480 & S39.06190 & E170.83479 & E172.00670 & 1800. & 2600 & 101.4 \\
\hline $72-169$ & S39.08710 & $\$ 39.32890$ & E170.88699 & E171.46201 & $400^{\circ}$ & 800 & 56.4 \\
\hline 80MA-107 & S39.19951 & S39.65844 & E173.28845 & E173.42601 & 9099 & 11198 & 52.4 \\
\hline 80MA-108 & S39.39359 & S39.53481 & E173.19592 & E173.36067 & 6700 & 7548 & 21.0 \\
\hline $80 \mathrm{NM}-100$ & S39.26733 & S39.39894 & E173.02670 & E173.20213 & 8600 & 9447 & 21.1 \\
\hline 80NM-101 & S39.25334 & S39.43664 & E173.12305 & E173.37404 & 7299 & 8487 & 29.6 \\
\hline $80 \mathrm{NM}-102$ & S39.23693 & S39.39697 & E173.15857 & E173.38075 & 6199 & 7249 & 26.1 \\
\hline 80NM-103 & S39.25520 & S39.33335 & E173.29839 & E173.40215 & 5651 & 6151 & 12.7 \\
\hline $80 \mathrm{Z}-1$ & S38.19726 & S38.47847 & E173.23856 & E173.23921 & 99 & 1351 & 31.2 \\
\hline $80 Z-11$ & S38.27028 & S38.48167 & E173.44609 & E173.44804 & 5300 & 6244 & 23.4 \\
\hline $80 \mathrm{Z}-11 \mathrm{C}$ & S38.17955 & S38.28032 & E173.44493 & E173.44609 & 7499 & 7946 & 11.0 \\
\hline $80 Z-12$ & S38.32974 & S38.33022 & E173.18648 & E173.54175 & 2099 & 3346 & 31.0 \\
\hline $80 Z-16$ & S38.39918 & S38.40057 & E173.18794 & E173.54179 & 8599 & 9848 & 30.9 \\
\hline $80 \mathrm{Z}-2$ & S38.19286 & S38.19333 & E173.34953 & E173.54857 & 1449 & 2146 & 17.2 \\
\hline $80 Z-20$ & S38.46385 & S38.46497 & E173.18361 & E173.46155 & 6299 & 7280 & 24.2 \\
\hline $80 Z-4$ & S38.22175 & S 38.22329 & E173.19839 & E173.66891 & 5400 & 7049 & 41.1 \\
\hline $80 Z-7$ & S38.23594 & S38.41489 & E173.35190 & E173.35304 & 3599 & 4394 & 20.0 \\
\hline 80Z-7A & S38.17673 & S38.25353 & E173.35133 & E173.35201 & 4500 & 4844 & 8.6 \\
\hline 80Z-8 & S38.27438 & S38.27531 & E173.18864 & E173.54269 & $4093^{\circ}$ & 5343 & 30.9 \\
\hline $81 \mathrm{~A}-03$ & S38.47958 & S38.66497 & E173.36722 & E173.72742 & 5900 & 7401 & 37.6 \\
\hline $81 A-10$ & S38.66178 & S38.66211 & E173.52107 & E173.76515 & 3549 & 4399 & 21.1 \\
\hline $81 \mathrm{~A}-10 \mathrm{~A}$ & S38.66195 & S38.66231 & E173.77893 & E173.92258 & 3001 & 3501 & 12.3 \\
\hline $81 A-11$ & S38.46409 & S38.72150 & E173.50592 & E174.00899 & 20800 & 22894 & 52.3 \\
\hline $81 \mathrm{~B}-01$ & S38.51641 & S38.51830 & E173.00027 & E173.37257 & 15000 & 16299 & 32.5 \\
\hline $81 B-02$ & S38.58938 & S38.66792 & E173.00699 & E173.00763 & 14399 & 14748 & 8.8 \\
\hline $81 \mathrm{~B}-02 \mathrm{~A}$ & S38.48967 & S38.57815 & E173.00703 & E173.00778 & 14099 & 14496 & 9.9 \\
\hline 81B-03A & S38.58983 & S38.59058 & E173.00179 & E173.33009 & 15000 & 16144 & 28.6 \\
\hline $81 B-04$ & S38.48603 & S38.67629 & E173.08667 & E173.08780 & 13399 & 14242 & 21.1 \\
\hline $81 B-06$ & S38.59268 & S38.66850 & E173.15472 & E173.15558 & 2200 & 2545 & 8.3 \\
\hline $81 B-06 A$ & S38.48625 & S38.57833 & E173.15442 & E173.15533 & 12850 & 13250 & 10.1 \\
\hline
\end{tabular}


28

\begin{tabular}{|c|c|c|c|c|c|c|c|}
\hline 81B-07 & S38.66164 & S38.66287 & E173.13210 & E173.50633 & 4450 & 5753 & 32.5 \\
\hline 81B-07A & S38.66180 & S38.66249 & E172.98882 & E173.11598 & 14500 & 14943 & 11.0 \\
\hline 81B-08 & S38.37350 & S38.66752 & E173.30290 & E173.32103 & 12801 & 14298 & 32.8 \\
\hline $81 \mathrm{NM}-203$ & S38.86750 & S39.25424 & E173.27409 & E173.27510 & 16400 & 18117 & 43.0 \\
\hline $81 N M-210$ & S39.08430 & S39.08670 & E173.17329 & E173.41870 & 27400 & 28249 & 21.3 \\
\hline 81SY-01 & S38.42753 & S38.42833 & E173.68117 & E174.00984 & 14600 & 15748 & 28.6 \\
\hline 81SY-02P1 & S38.45829 & S38.52553 & E173.57480 & E173.57613 & 8200 & 8499 & 7.0 \\
\hline 81SY-02P2 & S38.39761 & S38.45439 & E173.57735 & E173.57822 & 13699 & 13951 & 5.9 \\
\hline 81SY-02P3 & S38.26172 & S38.38670 & E173.57831 & E173.58047 & 18740 & 19295 & 13.8 \\
\hline 81SY-02P4 & S38.04192 & S38.25644 & E173.58029 & E173.58398 & 19699 & 20651 & 23.8 \\
\hline 81SY-03 & S38.38208 & S38.38359 & E173.68208 & E174.00926 & 17100 & 18244 & 28.6 \\
\hline 81SY-05 & S38.33700 & S38.33801 & E173.58322 & E173.92439 & 15800 & 16993 & 29.7 \\
\hline 81SY-11 & S38.28869 & S38.29250 & E173.47450 & E174.00224 & 20500 & 22347 & 46.1 \\
\hline 81SY-12P1 & S38.08644 & S38.22205 & E173.87021 & E173.87515 & 25099 & 25701 & 15.1 \\
\hline $81 S Y-12 P 2$ & S38.22591 & S38.43744 & E173.86249 & E173.87024 & 25999 & 26938 & 23.5 \\
\hline 81SY-13 & S38.24456 & S38.24793 & E173.57585 & E174.00882 & 22399 & 23915 & 37.8 \\
\hline 81SY-14 & S38.04917 & S38.50906 & E173.91898 & E173.92389 & 100 & 2142 & 51.2 \\
\hline 81SY-14B & S38.52304 & S38.66827 & E173.91739 & E173.91881 & $2204^{\circ}$ & 2848 & 16.2 \\
\hline 81SY-15P1 & S38.20071 & S38.20386 & E173.63187 & E174.00211 & 24000 & 25297 & 32.3 \\
\hline $81 S Y-15 P 2$ & S38.19983 & S38.20050 & E173.56187 & E173.61372 & 25600 & 25782 & 4.4 \\
\hline 81SY-16 & S38.07686 & S38.48114 & E173.98241 & E173.98744 & 23200 & 24995 & 45.0 \\
\hline 81SY-17P1 & S38.15548 & S38.15631 & E173.52287 & E173.63600 & 25799 & 26196 & 9.9 \\
\hline 81SY-17P2 & S38.15609 & S38.15739 & E173.65099 & E174.01381 & 26518 & 27790 & 31.8 \\
\hline 81SY-19P1 & S38.10864 & S38.10889 & E173.93646 & E174.00227 & 28300 & 28531 & 5.9 \\
\hline 81SY-19P2 & S38.10905 & S38.11050 & E173.57509 & E173.92288 & 28719 & 29939 & 30.5 \\
\hline 81SY-21 & S38.05170 & S38.05304 & E173.58044 & E174.01353 & 30000 & 31521 & 38.0 \\
\hline $81 \mathrm{Z}-32 \mathrm{P} 1$ & S38.38765 & S38.44237 & E173.61234 & E173.72012 & 199 & 647 & 11.3 \\
\hline $81 \mathrm{Z}-32 \mathrm{P} 2$ & S38.44419 & S38.59566 & E173.30597 & E173.60786 & 800 & 2050 & 31.3 \\
\hline $81 Z-34$ & S38.43193 & S38.67783 & E173.41063 & E173.51244 & 11599 & 12748 & 28.7 \\
\hline AS1 & S41.01725 & S41.07980 & E173.12001 & E173.36804 & 1820 & 1930 & 21.8 \\
\hline AS11 & S40.78812 & S40.81578 & E173.45222 & E173.79616 & 560 & 736 & 29.1 \\
\hline AS12 & S40.67168 & S40.72410 & E173.43770 & E173.90443 & 739 & 939 & 39.8 \\
\hline AS13 & S40.55060 & S40.95156 & E173.40408 & E173.49249 & 0 & 227 & 45.2 \\
\hline AS15 & S40.82058 & S40.93554 & E173.71805 & E173.72787 & 494 & 558 & 12.7 \\
\hline AS2 & S40.95685 & S40.97630 & E173.09392 & E173.33501 & $1711^{\circ}$ & 1814 & 20.3 \\
\hline AS3 & S40.86826 & S40.88911 & E173.08644 & E173.32004 & 1610 & 1709 & 19.8 \\
\hline AS4 & S40.80508 & S40.83057 & E173.07843 & E173.32484 & 1499 & 1604 & 20.9 \\
\hline AS7 & S40.61753 & S40.77640 & E173.02246 & E173.19411 & 1339 & 1454 & 22.7 \\
\hline AS8 & S40.40729 & S41.07443 & E173.11133 & E173.33705 & 1940 & 2323 & 76.6 \\
\hline AS9 & S40.37268 & S40.41772 & E173.10988 & E173.17484 & 230 & 267 & 7.3 \\
\hline B & S39.16346 & S39.17127 & E170.99091 & E172.49899 & 0 & 2854 & 130.1 \\
\hline $\mathrm{C}$ & S39.31377 & S39.31727 & E171.27599 & E172.01672 & 2 & 1400 & 63.8 \\
\hline $\mathrm{C} 4$ & S39.64402 & S39.68788 & E173.12749 & E173.31927 & 864 & 949 & 17.2 \\
\hline C4EXT & S39.67870 & S39.70254 & E173.05247 & E173.16060 & 1130 & 1179 & 9.6 \\
\hline CK81-02 & S40.49580 & S40.69815 & E171.54919 & E171.93941 & 100 & 1698 & 39.9 \\
\hline CK81-08 & S40.75730 & S40.81413 & E171.71519 & E171.82555 & 99 & 550 & 11.3 \\
\hline
\end{tabular}




\begin{tabular}{|c|c|c|c|c|c|c|c|}
\hline CK81-08A & S40.61225 & S40.76370 & E171.43478 & E171.72720 & 500 & 1698 & 29.9 \\
\hline CK81-13A & S40.73505 & S40.93460 & E171.32228 & E171.71539 & 100 & 1698 & 39.9 \\
\hline CK81-19 & S40.99137 & S41.28067 & E171.48785 & E172.05466 & 99 & 2395 & 57.4 \\
\hline CK81-1A & S40.40023 & S40.43660 & E172.09712 & E172.25211 & 99 & 650 & 13.6 \\
\hline CK81-20 & S41.17820 & S41.30175 & E171.73610 & E171.98500 & 100 & 1098 & 24.9 \\
\hline CK81-20A & S41.30830 & S41.32026 & E171.99789 & E172.02260 & 1150 & 1248 & 2.2 \\
\hline CK81-21 & S40.91597 & S40.99937 & E171.16786 & E171.32675 & 99 & 749 & 16.2 \\
\hline CK81-23 & S41.15997 & S41.35972 & E171.46376 & E171.86206 & 99 & 1701 & 40.1 \\
\hline CK81-29A & S40.48260 & S40.99419 & E171.29173 & E171.75310 & 99 & 2850 & 68.9 \\
\hline CK81-2B & S40.69210 & S40.78008 & E171.92760 & E172.09875 & 1650 & 2349 & 17.4 \\
\hline CK81-31A & S40.39049 & S40.97650 & E171.59779 & E172.11974 & 100 & 3249 & 78.7 \\
\hline CK81-35 & S40.76150 & S40.98370 & E171.89211 & E172.08890 & 100 & 1300 & 29.8 \\
\hline CK81-36 & S40.82699 & S41.50160 & E171.46390 & E172.05833 & 100 & 3699 & 90.1 \\
\hline CK81-39 & S40.94350 & S41.02989 & E171.99025 & E172.06090 & 99 & 550 & 11.3 \\
\hline CP1 & S37.96820 & S39.31072 & E171.34290 & E172.60060 & 1300 & 3200 & 185.0 \\
\hline $\mathrm{CP} 4$ & S36.69710 & S37.18300 & E169.21519 & E170.17281 & 1000 & 2000 & 100.9 \\
\hline CP5 & S38.28090 & S38.53030 & E171.11200 & E172.11121 & 100. & 1100 & 91.4 \\
\hline $\mathrm{CP} 6$ & S37.79320 & S38.22760 & E171.06670 & E171.53650 & $1200^{\circ}$ & 1830 & 63.5 \\
\hline $\mathrm{CS} 1$ & S40.92505 & S40.96021 & E173.28299 & E173.72665 & 1 & 189 & 37.5 \\
\hline $\operatorname{CS} 13$ & S40.04971 & S40.11290 & E172.79807 & E173.18961 & 4330 & 4500 & 34.1 \\
\hline CS14 & S40.02333 & S40.10448 & E172.89102 & E173.17661 & 1195 & 1326 & 26.0 \\
\hline CS15 & S40.11837 & S40.21282 & E172.83458 & E173.13719 & 2249 & 2388 & 27.8 \\
\hline CS16 & S40.15474 & S40.24374 & E172.83354 & E173.12509 & 4795 & 4929 & 26.7 \\
\hline CS17 & S40.00674 & S40.41349 & E172.30009 & E172.92081 & 4032 & 4328 & 69.5 \\
\hline CS18 & S40.04667 & S40.41193 & E172.84587 & E173.01204 & 5234 & 5445 & 43.0 \\
\hline CS19 & S40.29496 & S40.96492 & E173.18321 & E173.35040 & 1694 & 2087 & 75.9 \\
\hline CS2 & S40.83496 & S40.86681 & E173.31264 & E173.72455 & 195 & 370 & 34.8 \\
\hline CS21 & S40.19307 & S40.76397 & E173.56308 & E173.57964 & 1370 & 1689 & 63.6 \\
\hline CS3 & S40.73637 & S40.78178 & E173.23079 & E173.80836 & 379 & 624 & 48.9 \\
\hline $\mathrm{CS} 4$ & S40.61650 & S40.67345 & E173.27031 & E173.99660 & 629 & 939 & 61.6 \\
\hline CS5 & S40.35528 & S40.42169 & E173.11322 & E173.66803 & 3090 & 3329 & 47.6 \\
\hline CS6 & S40.26663 & S40.45078 & E172.17352 & E173.79256 & 3334 & 4029 & 138.8 \\
\hline CS9 & S40.18885 & S 40.23863 & E173.08723 & E173.51790 & 2393 & 2579 & 37.1 \\
\hline D & S39.45948 & S39.46227 & E171.26350 & E172.00620 & 0 & 1400 & 63.8 \\
\hline DS282-1 & S40.23340 & S40.34380 & E173.13225 & E173.20682 & $100^{\circ}$ & 652 & 13.8 \\
\hline DS282-11 & S40.46860 & S40.65901 & E173.26367 & E173.39574 & 1119 & 2076 & 24.0 \\
\hline DS282-11A & S40.25890 & $S 40.47340$ & E173.39278 & E173.54036 & 50 & 1130 & 27.1 \\
\hline DS282-12 & S40.53105 & S40.59260 & E173.34949 & E173.50710 & 99 & 699 & 14.8 \\
\hline DS282-13 & S40.36030 & S40.53040 & E173.41040 & E173.52400 & 800 & 1648 & 21.4 \\
\hline DS282-13B & S40.53980 & S40.66985 & E173.31656 & E173.40398 & 1011 & 1660 & 16.4 \\
\hline DS282-17 & $\$ 40.50870$ & S40.70770 & E173.40816 & E173.54517 & 100 & 1098 & 25.0 \\
\hline DS282-2 & S40.64910 & S40.74459 & E173.26826 & E173.50264 & 100 & 999 & 22.5 \\
\hline DS282-20 & S40.33911 & S40.51000 & E173.12537 & E173.54675 & 100 & 1719 & 40.4 \\
\hline DS282-24 & S40.30330 & S40.45593 & E173.15964 & E173.53596 & 99 & 1546 & 36.2 \\
\hline DS282-28 & S40.26345 & S40.39414 & E173.18539 & E173.51076 & 99 & 1348 & 31.2 \\
\hline DS282-3 & S40.20695 & S40.34581 & E173.20911 & E173.30455 & 100 & 797 & 17.4 \\
\hline
\end{tabular}


30

\begin{tabular}{|c|c|c|c|c|c|c|c|}
\hline DS282-32 & S40.23585 & S40.36743 & E173.20367 & E173.52686 & 101 & 1346 & 31. \\
\hline DS282-3A & S40.35610 & S40.37690 & E173.18791 & E173.20232 & 848 & 952 & \\
\hline DS282-4 & S40.61010 & S40.67216 & E173.29565 & E173.45053 & 100 & 692 & \\
\hline DS282-40 & S40.19601 & S40.29921 & E173.26318 & E173.51636 & 99 & 1075 & \\
\hline DS282-9 & S40.23060 & $S 40.44740$ & E173.32396 & E173.47626 & 100 & 1193 & 27. \\
\hline $\mathrm{E}$ & S39.60566 & S39.60981 & E171.27429 & E171.99597 & 48 & 1401 & \\
\hline $\mathrm{E} 1$ & S38.74084 & S38.74584 & E172.57265 & E173.18462 & 7951 & 8217 & 53.1 \\
\hline E2 & S38.89470 & S38.89980 & E172.57629 & E173.17700 & 8220 & 8480 & 52.0 \\
\hline E3 & S39.04208 & S39.04940 & E172.06441 & E173.20425 & 7190 & 7684 & 98.5 \\
\hline E4 & S39.31640 & S39.32276 & E172.04720 & E173.20329 & 6681 & 7180 & 99.5 \\
\hline E6 & S39.82126 & S39.82324 & E172.52969 & E172.66026 & 9163 & 9219 & 11.3 \\
\hline E7PT1 & S39.92840 & S40.02866 & E172.58569 & E172.93814 & 9829 & 9989 & 32.0 \\
\hline E7PT2 & S39.78826 & S39.92160 & E172.10339 & E172.56219 & 0 & 209 & 41.9 \\
\hline E8 & S38.73606 & S38.95290 & E172.57968 & E172.58130 & 8489 & 8610 & 24.0 \\
\hline EB-13 & S38.50310 & S38.50623 & E173.91696 & E174.24899 & 385 & 520 & 28.9 \\
\hline EB-31/1 & S38.42275 & S38.42385 & E173.96875 & E174.21095 & 1 & 102 & 21.1 \\
\hline EB-31/2 & S38.42381 & S 38.42480 & E173.91850 & E173.96193 & 150 & 169 & \\
\hline EB-31/3 & S38.42193 & S38.42384 & E174.21178 & E174.26788 & 178 & 203 & 5.0 \\
\hline EZC-1 & S40.39379 & S41.48324 & E171.20926 & E172.17249 & 1 & 729 & 145. \\
\hline EZC-10 & S41.21609 & S41.50518 & E171.06270 & E171.63138 & 2603 & 2891 & 57.3 \\
\hline EZC-11 & S41.33925 & S41.49671 & E170.96327 & E171.26849 & 2898 & 3053 & 30.9 \\
\hline EZC-4 & S40.53921 & S40.70303 & E171.79929 & E172.11987 & 879 & 1042 & 32.7 \\
\hline EZC-8 & S40.99422 & S41.35474 & E171.31755 & E172.02699 & 2167 & 2528 & 71.7 \\
\hline EZC-9 & S41.08684 & S41.45666 & E171.15297 & E171.88049 & 1783 & 2151 & 73.4 \\
\hline EZF-20 & S40.92333 & S41.50014 & E171.65358 & E172.03729 & 11 & 378 & 71.8 \\
\hline EZF-25 & $\mathrm{S} 40.80502$ & S40.92078 & E171.81152 & E172.03990 & 1537 & 1652 & 23.1 \\
\hline $\mathrm{EZF}-26$ & S40.92745 & S41.11515 & E171.70049 & E172.06496 & 2024 & 2208 & 37.1 \\
\hline $\mathrm{EZF}-32 \mathrm{P} 1$ & S41.35489 & S41.42653 & E171.45139 & E171.59297 & 875 & 946 & 14.3 \\
\hline $\mathrm{EZF}-32 \mathrm{P} 2$ & S41.43294 & S41.56647 & E171.60468 & E171.86852 & 2926 & 3059 & 26.6 \\
\hline $\mathrm{EZF}-40$ & S41.34801 & S41.43484 & E171.38269 & E171.45724 & 815 & 872 & 11.3 \\
\hline EZF-6 & S40.59790 & S40.78188 & E171.23570 & E171.59019 & 1840 & 2020 & 36.3 \\
\hline $\mathrm{F} 1$ & S39.65831 & S39.67253 & E171.93352 & E172.99905 & 0 & 1998 & 91.3 \\
\hline F17P1 & S39.26718 & S39.31314 & E173.30679 & E173.50037 & 4174 & 4259 & 17.5 \\
\hline F17P2 & S39.31700 & S39.35528 & E173.10947 & E173.29251 & 4265 & 4346 & 16.2 \\
\hline F18P1 & S39.40510 & S39.44956 & E173.11620 & E173.32390 & 4347 & 4440 & 18.6 \\
\hline $\mathrm{F} 18 \mathrm{P} 2$ & S39.36110 & S39.40441 & E173.33037 & E173.52931 & 4443 & 4534 & 17.8 \\
\hline F19 & S39.44060 & S39.53214 & E173.18250 & E173.58664 & 1962 & 2142 & 36.1 \\
\hline $\mathrm{F} 2$ & S39.66810 & S39.67281 & E171.00053 & E171.90591 & 2051 & 3749 & 77.5 \\
\hline $\mathrm{F} 20$ & S39.39120 & S39.58935 & E173.33580 & E173.47330 & 5360 & 5485 & 25.1 \\
\hline $\mathrm{F} 22$ & S39.38570 & S39.86822 & E173.20772 & E173.54543 & 1614 & 1938 & 61.0 \\
\hline F23 & S39.59394 & S39.74051 & E173.33873 & E173.44449 & 211 & 304 & 18.7 \\
\hline F26 & S39.69296 & S39.75670 & E173.06480 & E173.06516 & 1184 & 1219 & 7.3 \\
\hline F4P1 & S39.43720 & S39.59570 & E173.32249 & E173.54401 & 3070 & 3200 & 25.8 \\
\hline F4P1A & S39.58481 & S39.64660 & E173.52798 & E173.61530 & 3028 & 3079 & 10.1 \\
\hline $\mathrm{F} 4 \mathrm{P} 2$ & S39.25672 & S39.40226 & E173.07318 & E173.27063 & 3229 & 3347 & 23.5 \\
\hline F6 & S39.51579 & S39.65884 & E173.21953 & E173.41289 & 2151 & 2266 & 23.0 \\
\hline
\end{tabular}


31

\begin{tabular}{|c|c|c|c|c|c|c|c|}
\hline F6B & S39.67660 & S39.75070 & E173.43680 & E173.53729 & 2280 & 2340 & 11.9 \\
\hline F7 & S39.59835 & S39.68886 & E173.25420 & E173.37675 & 2456 & 2529 & 14.5 \\
\hline F7A & S39.70296 & S39.78910 & E173.39409 & E173.51105 & 2341 & 2449 & 13.8 \\
\hline F8 & S39.64921 & S39.73320 & E173.23901 & E173.35300 & 2531 & 2600 & 13.4 \\
\hline F8B & S39.73824 & S39.81220 & E173.36005 & E173.46152 & 2604 & 2664 & 11.9 \\
\hline FS1 & $S 40.00510$ & S40.43935 & E172.65077 & E174.11470 & 1830 & 2502 & 133.4 \\
\hline FS10 & S40.55525 & S 40.63443 & E172.14096 & E172.39311 & 10723 & 10935 & 22.9 \\
\hline FS11 & S40.69318 & S40.93614 & E172.76840 & E173.65919 & 7148 & 7951 & 79.7 \\
\hline FS12 & S40.88245 & S41.02183 & E173.08888 & E173.58820 & 5356 & 5809 & 44.7 \\
\hline FS13 & S41.02262 & S41.09279 & E173.20506 & E173.46461 & 5820 & 6049 & 23.2 \\
\hline FS14 & S41.10653 & S41.16989 & E173.10339 & E173.34644 & 6051 & 6267 & 21.6 \\
\hline FS15 & S40.34923 & S 40.51210 & E172.14412 & E172.32217 & 9270 & 9389 & 23.6 \\
\hline FS17 & S40.36676 & S40.70894 & E172.12071 & E172.51622 & 9682 & 10187 & 50.6 \\
\hline FS18/1 & S40.33627 & S40.71411 & E172.28625 & E172.68459 & 8453 & 8725 & 53.8 \\
\hline FS $18 / 2$ & S40.05824 & S40.33454 & E172.68069 & E172.97684 & 3091 & 3292 & 39.8 \\
\hline FS20 & $S 40.62126$ & S40.71894 & E172.75613 & E172.84940 & 7013 & 7145 & 13.4 \\
\hline FS21_PT1 & S40.51161 & S40.76706 & E172.93193 & E173.20248 & 3558. & 3736 & 36.5 \\
\hline FS21_PT2 & S40.33503 & S40.50949 & E173.20070 & E173.38420 & $4215^{\circ}$ & 4341 & 24.8 \\
\hline FS 22 & S 40.27626 & S40.92007 & E173.08771 & E173.74467 & 4814 & 5355 & 90.6 \\
\hline FS23 & S40.75947 & S41.11687 & E173.13013 & E173.49800 & 6274 & 6715 & 50.4 \\
\hline FS24-PT1 & S40.37558 & S40.84745 & E173.59911 & E174.07838 & 100 & 433 & 66.3 \\
\hline FS24_PT2 & S40.85223 & S41.20144 & E173.23111 & E173.59367 & 7956 & 8449 & 49.3 \\
\hline FS28 & S40.69895 & S40.70465 & E172.13911 & E172.31046 & 10936 & 11107 & 14.5 \\
\hline FS3 & S40.10497 & S40.56798 & E172.49139 & E174.11652 & 438 & 1179 & 147.1 \\
\hline FS4 & S40.29026 & S40.65071 & E172.66641 & E173.93147 & 2508 & 3081 & 114.3 \\
\hline FS4W & S 40.24300 & S40.29920 & E172.50269 & E172.68822 & 9596 & 9680 & 17.1 \\
\hline FS5 & S40.41937 & S40.73775 & E172.65259 & E173.77957 & 1180 & 1692 & 101.6 \\
\hline FS5W & S40.28347 & S 40.42101 & E172.20546 & E172.65868 & 8725 & 8934 & 41.4 \\
\hline FS6 & S40.38137 & S40.46301 & E172.28688 & E172.55933 & 10192 & 10444 & 24.7 \\
\hline FS8 & S40.44416 & S40.55285 & E172.18573 & E172.54564 & 8937 & 9267 & 32.8 \\
\hline FS9 & S40.60963 & S40.70858 & E172.72995 & E173.08627 & 3741 & 3900 & 32.0 \\
\hline G & S39.81195 & S39.81593 & E171.26384 & E172.01245 & 2 & 1402 & 64.0 \\
\hline G4 & S40.03838 & S40.04478 & E173.90134 & E174.35509 & 9573 & 9766 & 38.6 \\
\hline G5 & S40.19548 & S40.19876 & E173.48827 & E174.30315 & 9222 & 9569 & 69.3 \\
\hline G6 & S40.18084 & S40.25908 & E173.47398 & E173.74870 & 5713 & 5838 & 24.9 \\
\hline G6B & S40.25980 & S40.38464 & E173.75040 & E174.19089 & 5839 & 6038 & 39.8 \\
\hline G8 & S39.62606 & S40.35396 & E173.96396 & E174.01910 & 6041 & 6459 & 81.1 \\
\hline $\mathrm{H}$ & S39.95333 & S39.95933 & E171.27327 & E172.02174 & 2 & 1399 & 63.8 \\
\hline HF00X & S37.99400 & S38.10068 & E174.69974 & E174.73250 & 4800 & 5284 & 12.3 \\
\hline HF1/0 & S38.28920 & S38.58335 & E174.56602 & E174.56700 & 7189 & 7841 & 32.8 \\
\hline $\mathrm{HF} 1 / 0$ & S38.58335 & S38.60328 & E174.56667 & E174.56680 & 7841 & 7885 & 2.2 \\
\hline $\mathrm{HF} 1 / 1$ & S38.06990 & S38.30184 & E174.56641 & E174.56688 & 4712 & 5226 & 25.8 \\
\hline $\mathrm{HF} 1 / 2$ & S38.00185 & S38.07990 & E174.56639 & E174.56670 & 5256 & 5429 & 8.6 \\
\hline HF1090P1 & S37.96435 & S38.10020 & E173.88049 & E173.88229 & 7456 & 7758 & 15.1 \\
\hline HF1094P1 & S38.31719 & S38.50255 & E173.83037 & E173.83449 & 930 & 1342 & 20.6 \\
\hline HF1094P2 & S38.07368 & S38.30945 & E173.83459 & E173.83923 & 1430 & 1967 & 26.3 \\
\hline
\end{tabular}


32

\begin{tabular}{|c|c|c|c|c|c|c|c|}
\hline $\mathrm{HF} 11 / 0$ & S38.62460 & S38.62510 & E174.47990 & E174.53200 & 2510 & 2600 & 4.4 \\
\hline HF11/0 & S38.62493 & S38.62531 & E174.51268 & E174.59203 & 2566 & 2704 & 6.6 \\
\hline HF11/1 & S38.62440 & S38.62487 & E174.23190 & E174.47911 & 2730 & 3160 & 21.5 \\
\hline HF1100 & S38.25045 & S38.66780 & E173.76860 & E173.77538 & 1300 & 2225 & 46.5 \\
\hline $\mathrm{HF} 1100 \mathrm{~N}$ & S37.99941 & S38.27113 & E173.77361 & E173.77847 & 2849 & 3449 & 30.3 \\
\hline HF1110N & S37.99984 & S38.24550 & E173.64897 & E173.65511 & 29555 & 30101 & 27.3 \\
\hline HF1110S & S38.24810 & S38.66780 & E173.64211 & E173.64890 & 28620 & 29550 & 46.7 \\
\hline $\mathrm{HF} 1120 \mathrm{~N}$ & S38.13939 & S38.23682 & E173.52827 & E173.52943 & 107 & 325 & 10.6 \\
\hline HF1120S & S38.24818 & S38.67482 & E173.52832 & E173.52995 & 349 & 1292 & 47.4 \\
\hline HF11X & S38.62422 & S38.62490 & E173.61972 & E173.79376 & 19428 & 19732 & 15.0 \\
\hline HF11XB & S38.62422 & S38.62590 & E173.79265 & E174.25386 & 19730 & 20533 & 40.1 \\
\hline HF12 & S38.58007 & S38.58115 & E174.24872 & E174.56403 & 1899 & 2449 & 27.3 \\
\hline HF12 & S38.58080 & S38.58118 & E174.56403 & E174.59090 & 2449 & 2495 & 2.2 \\
\hline $\mathrm{HF} 13 / 0$ & S38.53680 & S38.53715 & E174.48981 & E174.59583 & 1220 & 1405 & 9.1 \\
\hline $\mathrm{HF} 13 / 1$ & S38.53680 & S38.53710 & E174.22966 & E174.49045 & 1430 & 1884 & 22.6 \\
\hline HF14 & S38.49215 & S38.49285 & E174.24153 & E174.58572 & 551 & 1151 & 30.0 \\
\hline $\mathrm{HF} 15 / 0$ & S38.44790 & S38.44833 & E174.47234 & E174.60339 & 9875. & 10103 & 11.3 \\
\hline $\mathrm{HF} 15 / 1$ & S38.44815 & S38.44887 & E174.23015 & E174.49229 & $129^{\circ}$ & 547 & 22.8 \\
\hline HF16 & S38.40280 & S38.40400 & E174.24136 & E174.58760 & 9252 & 9856 & 30.2 \\
\hline $\mathrm{HF} 17 / 0$ & S38.35950 & S38.35970 & E174.48737 & E174.60873 & 8419 & 8631 & 10.6 \\
\hline HF17/1 & S38.35920 & S38.35970 & E174.14597 & E174.48305 & 8659 & 9247 & 29.4 \\
\hline HF18 & S38.31504 & S38.31570 & E174.15709 & E174.62614 & 6307 & 7126 & 40.9 \\
\hline HF18 & S38.31553 & S38.31568 & E174.62614 & E174.66562 & 7126 & 7195 & 2.2 \\
\hline HF19/0 & S38.26940 & S38.26971 & E174.543,84 & E174.60985 & 629 & 746 & 5.9 \\
\hline HF $19 / 0$ & S38.26955 & S38.27010 & E174.61592 & E174.66531 & 755 & 841 & 4.4 \\
\hline HF19/1 & S38.26990 & S38.27061 & E174.14464 & E174.54118 & 867 & 1561 & 34.6 \\
\hline $\mathrm{HF} 2 / 0$ & S38.34990 & S38.66155 & E174.48610 & E174.48660 & 118 & 809 & 34.7 \\
\hline $\mathrm{HF} 2 / 1$ & S37.98875 & S38.36620 & E174.48650 & E174.48779 & 3863 & 4700 & 42.0 \\
\hline $\mathrm{HF} 20$ & S38.22438 & S38.22490 & E174.16330 & E174.62610 & 9700 & 10510 & 40.4 \\
\hline HF20 & S38.22486 & S38.22490 & E174.62726 & E174.66231 & 10512 & 10573 & 2.2 \\
\hline HF21/0 & S38.17942 & S38.17979 & E174.60014 & E174.66924 & 8879 & 8999 & 5.4 \\
\hline $\mathrm{HF} 21 / 0$ & S38.17950 & S38.17980 & E174.53207 & E174.61726 & 8759 & 8909 & 7.7 \\
\hline HF $21 / 1$ & S38.17929 & S38.17988 & E174.14606 & E174.53288 & 9004 & 9682 & 33.8 \\
\hline $\mathrm{HF} 23 / 0$ & S38.09005 & S38.09010 & E174.62140 & E174.63945 & 7431 & 7463 & 2.2 \\
\hline $\mathrm{HF} 23 / 0$ & S38.09005 & S38.09020 & E174.52344 & E174.62845 & $7259^{\circ}$ & 7443 & 9.1 \\
\hline $\mathrm{HF} 23 / 1$ & S38.09006 & S38.09040 & E174.24309 & E174.52170 & 7500 & 7988 & 24.4 \\
\hline HF23EXT & S38.08950 & S38.09050 & E174.63136 & E174.73039 & 4415 & 4761 & 8.6 \\
\hline HF23X & S38.08951 & S38.09140 & E173.97757 & E174.23387 & 7949 & 8398 & 22.5 \\
\hline HF24 & S38.04449 & S38.04520 & E174.24551 & E174.58568 & 6399 & 6995 & 29.9 \\
\hline HF24 & S38.04464 & S38.04540 & E174.57832 & E174.72754 & 6982 & 7242 & 13.1 \\
\hline $\mathrm{HF} 3 / 0$ & $S 38.62360$ & S38.66456 & E174.40781 & E174.40813 & 9668 & 9760 & 3.9 \\
\hline $\mathrm{HF} 3 / 1$ & S38.29806 & S38.41140 & E174.40691 & E174.40799 & 9840 & 10091 & 12.5 \\
\hline $\mathrm{HF} 3 / 2$ & S38.39008 & S38.62397 & E174.40759 & E174.40840 & 7885 & 8404 & 26.0 \\
\hline $\mathrm{HF} 3 / 3$ & S37.99686 & S38.30815 & E174.40680 & E174.40782 & 3167 & 3857 & 34.6 \\
\hline $\mathrm{HF} 4 / 0$ & S38.27073 & S38.67276 & E174.25580 & E174.25684 & 5414 & 6305 & 44.8 \\
\hline HF4/1 & S37.97850 & S38.29204 & E174.25641 & E174.25705 & 1563 & 2258 & 34.8 \\
\hline
\end{tabular}


33

\begin{tabular}{|c|c|c|c|c|c|c|c|}
\hline $\mathrm{HF} 5 / 0$ & S38.16620 & S38.37315 & E174.17010 & E174.17119 & 2260 & 2719 & 23.0 \\
\hline HF510 & S38.57536 & S38.57713 & E173.33783 & E173.80038 & 20771 & 21579 & 40.3 \\
\hline HF510A & S38.57500 & S38.57580 & E173.81245 & E173.92720 & 20550 & 20750 & 10.4 \\
\hline HF520 & S38.49461 & S38.49600 & E173.63248 & E173.95796 & 6733 & 7299 & 28.3 \\
\hline HF530 & S38.41800 & S38.42348 & E173.34460 & E173.70406 & 21800 & 22430 & 31.4 \\
\hline HF600 & S37.99940 & S38.00130 & E173.66226 & E173.98680 & 2169 & 2739 & 28.5 \\
\hline HF600B & S37.99889 & S38.00125 & E173.99266 & E174.24989 & 2749 & 3200 & 22.6 \\
\hline HF61 & S38.20230 & S38.20250 & E174.55249 & E174.62572 & 7671 & 7928 & 6.6 \\
\hline HF61 & S38.20240 & S38.20250 & E174.62572 & E174.67848 & 7928 & 8112 & 4.4 \\
\hline HF71 & S38.07688 & S38.31643 & E174.60730 & E174.61086 & 3984 & 5049 & 26.6 \\
\hline HZ-32 & S40.72646 & S40.73120 & E170.99594 & E171.47623 & 0 & 599 & 40.4 \\
\hline $\mathrm{HZ}-7 \mathrm{~A}$ & S38.36790 & S38.58080 & E174.05515 & E174.11931 & 2 & 369 & 24.3 \\
\hline HZT82C-100 & S40.48912 & S40.49380 & E170.99911 & E172.00053 & 100 & 3496 & 84.7 \\
\hline HZT82C-101 & S40.37130 & S40.49707 & E171.57616 & E171.57803 & 97 & 648 & 14.0 \\
\hline HZT82C-103 & S40.36110 & S40.49553 & E171.68921 & E171.69051 & 99 & 696 & 15.0 \\
\hline HZT82C-106 & S40.39425 & S40.39872 & E171.13947 & E171.99231 & 50 & 2948 & 72.3 \\
\hline HZT82C-107 & $S 40.35260$ & S40.49463 & E171.78520 & E171.78740 & 99 & 730 & 15.8 \\
\hline HZT82C-109 & S40.36937 & S40.49245 & E171.97141 & E171.97565 & 98 & 645 & 13.6 \\
\hline HZTA-100 & S39.98199 & S39.98230 & E173.50050 & E173.99831 & 99 & 1800 & 42.5 \\
\hline HZTA-101 & S39.62448 & $S 40.00050$ & E173.52362 & E173.52382 & 100 & 1770 & 41.8 \\
\hline HZTA-107 & S39.59090 & S40.00050 & E173.59500 & E173.59538 & 100 & 1919 & 45.6 \\
\hline HZTA-110 & S39.89266 & S39.89310 & E173.49565 & E174.00153 & 80 & 1811 & 43.2 \\
\hline HZTA-117 & S39.48757 & $\$ 40.00050$ & E173.71400 & E173.71429 & 100 & 2378 & 57.0 \\
\hline HZTA-118 & S39.82127 & S39.82729 & E173.49911 & E174.11766 & 99 & 2218 & 52.9 \\
\hline HZTA-126 & S39.74914 & S39.75018 & E173.49527 & E173.99524 & 79 & 1793 & 42.8 \\
\hline HZTA-127 & S39.49977 & S40.00380 & E173.83310 & E173.83339 & 79 & 2318 & 56.1 \\
\hline HZTA-132 & S39.69624 & S39.69660 & E173.49911 & E174.01184 & 99 & 1858 & 43.9 \\
\hline HZTA-137 & S39.58932 & $S 40.00072$ & E173.95219 & E173.95244 & 99 & 1926 & 45.8 \\
\hline HZTA-142 & S39.60693 & S39.61068 & E173.48412 & E173.96623 & 379 & 2036 & 41.4 \\
\hline HZTA-152 & S39.51740 & S39.51808 & E173.58231 & E173.86192 & 99 & 1061 & 24.0 \\
\hline HZTA-90 & S39.97605 & S40.03950 & E173.23743 & E173.55354 & 159 & 1275 & 27.8 \\
\hline HZTB-110 & S38.82316 & S38.82345 & E174.39874 & E174.49811 & 330 & 675 & 8.6 \\
\hline HZTB-110 & S38.82340 & S38.82368 & E174.49062 & E174.54726 & 649 & 846 & 5.0 \\
\hline HZTB-114 & S38.78910 & S38.78946 & E174.40469 & E174.49992 & 350 & 681 & 8.3 \\
\hline HZTB-114 & S38.78947 & S38.78968 & E174.50050 & E174.56041 & 683 & 891 & 4.4 \\
\hline HZTB-124 & S38.71703 & S38.71730 & E174.51399 & E174.57547 & 717 & 931 & 5.4 \\
\hline HZTB-124 & S38.71730 & S38.71790 & E174.33670 & E174.50853 & 100 & 698 & 14.8 \\
\hline HZTB-201 & S38.50163 & S38.63650 & E174.01311 & E174.02638 & 100 & 703 & 15.0 \\
\hline HZTB-203 & S38.58195 & S38.75903 & E173.99701 & E174.06630 & 59 & 875 & 20.7 \\
\hline HZTB-205 & S38.50008 & S38.74970 & E174.07671 & E174.19539 & 100 & 1285 & 29.6 \\
\hline HZTB-212 & S38.55975 & S38.62094 & E173.98976 & E174.27814 & 60 & 1094 & 26.1 \\
\hline HZTB-214 & S38.53910 & S38.60043 & E174.00140 & E174.28714 & 100 & 1135 & 25.9 \\
\hline I & S40.09993 & S40.10451 & E171.26158 & E172.01254 & 2 & 1401 & 63.9 \\
\hline $\mathrm{J} 1$ & S40.24415 & S40.24957 & E171.27309 & E172.02205 & 2 & 1400 & 63.6 \\
\hline $\mathrm{J} 2$ & S40.31829 & S40.32327 & E171.26247 & E172.01251 & 2 & 1398 & 63.7 \\
\hline L & S39.16297 & S40.34354 & E171.44986 & E171.45435 & 1 & 2868 & 131.3 \\
\hline
\end{tabular}


34

\begin{tabular}{|c|c|c|c|c|c|c|c|}
\hline M & S39.16836 & S40.33844 & E171.63612 & E171.64391 & 3 & 2850 & 130.2 \\
\hline M21 & S40.11505 & S40.12343 & E173.32416 & E174.00975 & 1460 & 1704 & 58.3 \\
\hline M22/1 & S40.25211 & S41.44946 & E173.04321 & E174.33458 & 722 & 818 & 171.9 \\
\hline $\mathrm{M} 22 / 2$ & S40.25592 & S40.25945 & E173.66742 & E174.05600 & 2795 & 2923 & 33.0 \\
\hline M24 & S39.50000 & S39.81444 & E173.17000 & E173.17326 & 5300 & 5439 & 35.0 \\
\hline M25 & S39.98700 & S40.22068 & E173.53928 & E173.54298 & 2410 & 2510 & 25.9 \\
\hline M26 & S39.96639 & S40.27337 & E173.73225 & E173.73383 & 3850 & 3980 & 34.2 \\
\hline $\mathrm{M} 31 / 1$ & S40.25261 & S40.34215 & E173.91891 & E173.92024 & 1925 & 1964 & 9.9 \\
\hline M31/2 & S39.92958 & S40.25274 & E173.91333 & E173.91483 & 2646 & 2784 & 35.9 \\
\hline M32 & S40.21592 & S40.36385 & E174.10634 & E174.10892 & 1860 & 1923 & 16.4 \\
\hline MA15 & S39.52890 & S39.61255 & E173.35400 & E173.46074 & 7879 & 8140 & 12.9 \\
\hline MA15EX & S39.62979 & S39.66658 & E173.48183 & E173.52924 & 7711 & 7826 & 5.9 \\
\hline MA5 & S39.37651 & S39.55165 & E173.34270 & E173.56876 & 6750 & 7299 & 27.5 \\
\hline MA6 & S39.59014 & S39.70224 & E173.22334 & E173.51900 & 15732 & 16297 & 28.1 \\
\hline MOHO & S40.07303 & S40.42638 & E173.31241 & E174.18033 & 999 & 2039 & 83.5 \\
\hline $\mathrm{N}$ & S38.82989 & S40.33892 & E171.81976 & E171.83170 & 0 & 3682 & 167.9 \\
\hline NM02 & S38.89510 & S38.89559 & E173.15863 & E173.40387 & 4519. & 4944 & 21.3 \\
\hline NM1 & S39.04250 & S39.04350 & E173.19781 & E173.67099 & $2379^{\circ}$ & 3198 & 40.8 \\
\hline NM10 & S39.22688 & S39.22870 & E173.17960 & E173.64786 & 4520 & 5327 & 40.4 \\
\hline $\mathrm{NM} 10 / 1$ & S39.22730 & S39.22900 & E173.64084 & E173.74741 & 2303 & 2490 & 9.1 \\
\hline NM11/1 & S39.18206 & S39.18575 & E173.55832 & E173.66811 & 2499 & 2690 & 9.4 \\
\hline $\mathrm{NM} 11 / 1 \mathrm{~B}$ & S39.18190 & S39.18270 & E173.64432 & E173.75934 & 2649 & 2848 & 10.1 \\
\hline $\mathrm{NM} 11 / 2$ & S39.18150 & S39.18330 & E173.16014 & E173.56419 & 3800 & 4498 & 34.8 \\
\hline NM12/1 & S39.13330 & S39.13412 & E173.57106 & E173.84702 & 2851 & 3329 & 23.7 \\
\hline $\mathrm{NM} 12 / 2$ & S39.13339 & S39.13520 & E173.18622 & E173.58473 & 3079 & 3769 & 34.4 \\
\hline $\mathrm{NM} 13$ & S39.08860 & S39.09020 & E173.42850 & E173.66164 & 2649 & 3050 & 20.2 \\
\hline NM13A & S39.06982 & S39.09010 & E173.66121 & E173.91472 & 2204 & 2650 & 22.0 \\
\hline NM14 & S38.99358 & S38.99570 & E173.18376 & E173.77478 & 378 & 1401 & 51.1 \\
\hline $\mathrm{NM} 14 / 2$ & S38.99236 & S38.99527 & E173.98798 & E174.11310 & 1974 & 2191 & 10.8 \\
\hline NM14B & S38.99457 & S38.99500 & E173.75090 & E173.97989 & 1360 & 1751 & 19.8 \\
\hline NM15/0 & \$38.94219 & S38.94369 & E173.40320 & E173.73790 & 9350 & 9930 & 29.0 \\
\hline NM15/0A & S38.94134 & S38.94210 & E173.76776 & E173.90860 & 9055 & 9299 & 12.3 \\
\hline NM15/1 & S38.94400 & S38.94518 & E173.15862 & E173.36279 & 0 & 354 & 17.8 \\
\hline NM16 & S38.84329 & S38.84520 & E173.17810 & E173.70839 & 579 & 1499 & 46.0 \\
\hline $\mathrm{NM} 16 \mathrm{~B}$ & S38.84450 & S38.84600 & E173.76582 & E174.28560 & 1599 & 2500 & 45.0 \\
\hline NM17 & S38.78977 & S38.79189 & E173.17667 & E173.72861 & 3600 & 4559 & 47.9 \\
\hline NM17A & S38.78710 & S38.79220 & E173.76535 & E174.36191 & 2499 & 3536 & 51.7 \\
\hline NM18 & S38.69222 & S 38.69560 & E173.17320 & E173.70325 & 4600 & 5522 & 46.0 \\
\hline NM18B & S38.69089 & S38.69270 & E173.70551 & E174.33882 & 5526 & 6627 & 55.0 \\
\hline NM19/1 & S39.06876 & S39.12205 & E173.77991 & E173.78073 & 3374 & 3493 & 5.9 \\
\hline NM19/1B & S39.12520 & S39.17950 & E173.78040 & E173.78110 & 3500 & 3620 & 6.3 \\
\hline NM19/2 & S38.63960 & S39.06358 & E173.77953 & E173.78180 & 3628 & 4568 & 47.1 \\
\hline NM1B & S39.04308 & S39.04443 & E173.75909 & E173.99550 & 3350 & 3759 & 20.3 \\
\hline NM2 & S38.89530 & S38.89604 & E173.40535 & E173.71390 & 5600 & 6135 & 26.7 \\
\hline $\mathrm{NM} 2 / 0$ & S38.89602 & S38.89657 & E173.77740 & E173.99486 & 5113 & 5490 & 18.8 \\
\hline NM20 & S39.28120 & S39.46080 & E173.65741 & E173.65919 & 8750 & 9150 & 20.0 \\
\hline
\end{tabular}




\begin{tabular}{|c|c|c|c|c|c|c|c|}
\hline NM20/1 & $S 38.65200$ & S39.27040 & E173.65140 & E173.66110 & 4580 & 5950 & 68.8 \\
\hline $\mathrm{NM} 20 / 2 \mathrm{~B}$ & S39.48360 & S39.60970 & E173.65669 & E173.65781 & 9200 & 9480 & 14.0 \\
\hline NM21/1 & S39.22240 & S39.56612 & E173.53781 & E173.53891 & 687 & 1450 & 38.2 \\
\hline $\mathrm{NM} 21 / 2$ & S38.63820 & S39.21320 & E173.53780 & E173.53960 & 6050 & 7325 & 64.0 \\
\hline NM22 & S38.65610 & S39.29050 & E173.44659 & E173.44804 & 7346 & 8750 & 70.6 \\
\hline NM23 & S38.65010 & S38.89666 & E173.26067 & E173.26268 & 0 & 549 & 27.4 \\
\hline NM26 & $S 39.67090$ & S39.79306 & E173.16019 & E173.33026 & 4172 & 4598 & 20.0 \\
\hline $\mathrm{NM} 26 \mathrm{~A}$ & S39.80650 & S39.86642 & E173.34915 & E173.43199 & 3936 & 4128 & 10.1 \\
\hline NM26X & S39.83726 & S39.90601 & E173.42059 & E173.52892 & 4828 & 5069 & 11.9 \\
\hline NM27 & S39.66434 & S39.84605 & E173.18394 & E173.43497 & 4604 & 5179 & 29.5 \\
\hline NM29 & S39.39622 & S39.44280 & E173.56300 & E173.74438 & 8150 & 8477 & 16.5 \\
\hline NM3 & S38.74198 & S38.74269 & E173.16083 & E173.47800 & 6699 & 7250 & 27.5 \\
\hline NM3/1 & S38.74193 & S38.74260 & E173.41374 & E173.71140 & 750 & 1267 & 25.7 \\
\hline $\mathrm{NM} 3 / 1 \mathrm{~A}$ & S38.74267 & S38.74350 & E173.73267 & E174.07515 & 118 & 713 & 29.8 \\
\hline NM4 & S38.48530 & S38.74692 & E173.35271 & E173.35741 & 1267 & 1848 & 29.1 \\
\hline NM4N & S38.39826 & S38.48856 & E173.35173 & E173.35330 & 21591 & 21789 & 9.9 \\
\hline NM4X & S38.73576 & S39.27614 & E173.35640 & E173.35948 & 8783. & 9979 & 60.1 \\
\hline NM5 & S39.54050 & S39.56308 & E173.47508 & E173.57410 & $500^{\circ}$ & 677 & 8.6 \\
\hline NM5A & S39.48910 & S39.53446 & E173.60072 & E173.79781 & 100 & 452 & 17.6 \\
\hline NM6 & S39.45900 & S39.46000 & E173.49077 & E173.66490 & 9549 & 9849 & 15.0 \\
\hline NM6B & S39.45849 & S39.45921 & E173.69431 & E173.81049 & 9899 & 10098 & 9.9 \\
\hline NM7 & S39.36230 & S39.36602 & E173.49776 & E173.73431 & 1884 & 2298 & 20.3 \\
\hline NM8 & S39.31530 & S39.31830 & E173.48331 & E173.68149 & 1455 & 1797 & 17.1 \\
\hline NM9 & S39.27338 & S39.27835 & E173.16512 & E173.72430 & 7739 & 8704 & 48.2 \\
\hline NR7601 & S38.17070 & S39.01230 & E172.03740 & E172.41341 & 0 & 1000 & 99.2 \\
\hline NU01 & S38.94135 & S38.94238 & E173.89771 & E174.30353 & 3780 & 4483 & 35.2 \\
\hline NU11/1 & S38.68025 & S38.88255 & E174.48576 & E174.48669 & 4950 & 5399 & 22.4 \\
\hline NU12/0 & S38.82410 & S38.93230 & E174.40906 & E174.40976 & 9030 & 9270 & 12.1 \\
\hline NU12/1 & S38.66602 & S38.82255 & E174.40802 & E174.40930 & 9319 & 9667 & 17.4 \\
\hline NU13 & S38.65414 & S38.91817 & E174.33691 & E174.33926 & 9526 & 10111 & 29.4 \\
\hline NU14 & S38.67805 & S38.94425 & E174.25606 & E174.25630 & 8901 & 9491 & 29.6 \\
\hline NU15/0 & S38.87220 & S38.97355 & E174.16631 & E174.16734 & 8150 & 8373 & 11.3 \\
\hline NU15/1 & S38.73624 & S38.86615 & E174.16675 & E174.16730 & 8391 & 8679 & 14.5 \\
\hline NU16 & S 38.72842 & S39.02908 & E174.07124 & E174.07402 & 7436 & 8101 & 33.4 \\
\hline NU17 & S38.87413 & S39.05745 & E173.98483 & E173.98590 & 6434 & 6841 & 20.3 \\
\hline NU17X & S38.73143 & S38.88990 & E173.98560 & E173.98698 & 8699 & 9050 & 17.6 \\
\hline NU18 & S38.93610 & S39.08067 & E173.90218 & E173.90344 & 6846 & 7165 & 16.2 \\
\hline NU18X & S38.78240 & S38.93255 & E173.90140 & E173.90221 & 7885 & 8218 & 16.8 \\
\hline NU2/0 & S38.87784 & S38.87893 & E173.98790 & E174.32620 & 4488 & 5075 & 29.3 \\
\hline NU2/1 & S38.87783 & S38.87790 & E174.46512 & E174.49332 & 8974 & 9023 & 2.2 \\
\hline NU2/1 & S38.87783 & S38.87835 & E174.31311 & E174.49274 & 8710 & 9022 & 15.4 \\
\hline NU4 & S38.74512 & S38.74569 & E174.43253 & E174.50919 & 1215 & 1348 & 6.3 \\
\hline NU4 & S38.74561 & S38.74585 & E174.50394 & E174.56990 & 1339 & 1454 & 5.4 \\
\hline NU4/1 & S38.74360 & $S 38.74530$ & E174.12083 & E174.41966 & 8078 & 8597 & 25.9 \\
\hline NU5 & S38.66853 & S38.66933 & E174.51508 & E174.58862 & 1081 & 1209 & 6.3 \\
\hline NU5 & S38.66880 & S38.66990 & E174.06618 & E174.52428 & 301 & 1097 & 39.8 \\
\hline
\end{tabular}


36

\begin{tabular}{|c|c|c|c|c|c|c|c|}
\hline NU6 & S38.90860 & S38.90949 & E173.97166 & E174.29552 & 7311 & 7872 & 28.0 \\
\hline NZ-110 & S38.93203 & S39.26146 & E170.89909 & E172.20564 & 300 & 1200 & 118.6 \\
\hline NZ-30 & S38.49770 & S38.56280 & E172.90421 & E173.30659 & 2300 & 2600 & 35.8 \\
\hline $\mathrm{O}$ & S39.16119 & S40.33153 & E172.01028 & E172.02061 & 2 & 2850 & 130.2 \\
\hline P107-81-23 & S38.01190 & S38.01210 & E173.99800 & E174.36176 & 100 & 1378 & 31.9 \\
\hline P107-81-24 & S38.04770 & S38.04790 & E173.99568 & E174.29840 & 100 & 1163 & 26.4 \\
\hline P107-81-25 & S38.11960 & S38.12270 & E174.18739 & E174.60870 & 100 & 1578 & 36.9 \\
\hline P107-81-27 & S38.04326 & S38.21576 & E174.03481 & E174.39824 & 98 & 1585 & 37.2 \\
\hline P107-81-28 & S38.06819 & S38.24076 & E173.99799 & E174.36725 & 103 & 1607 & 37.6 \\
\hline P107-81-29 & S38.10408 & S38.27360 & E173.99411 & E174.35240 & 100 & 1564 & 36.7 \\
\hline P107-81-30 & S38.13951 & S38.30200 & E173.98462 & E174.32150 & 100 & 1483 & 34.6 \\
\hline P107-81-31 & S38.18508 & S38.33441 & E173.99806 & E174.31187 & 99 & 1382 & 32.0 \\
\hline P107-81-32 & S38.20738 & S38.36435 & E173.94936 & E174.27545 & 99 & 1436 & 33.5 \\
\hline P107-81-33 & S38.26823 & S38.40000 & E173.98703 & E174.26540 & 100 & 1236 & 28.4 \\
\hline P107-81-34 & S38.31569 & S38.45518 & E173.99806 & E174.29216 & 99 & 1299 & 30.0 \\
\hline P107-81-35 & S38.15828 & S38.33512 & E174.01624 & E174.06938 & 99 & 906 & 20.2 \\
\hline P107-81-35A & S37.99953 & S38.15598 & E174.07016 & E174.11722 & 901 & 1615 & 18.1 \\
\hline P107-81-38 & S37.99873 & S38.16853 & E174.28110 & E174.28110 & 99 & 853 & 18.8 \\
\hline P107-81-40 & S38.10899 & S38.36388 & E174.08459 & E174.28992 & 98 & 1439 & 33.6 \\
\hline P116-81-04 & S39.86950 & S39.87010 & E173.96429 & E174.51483 & 100 & 1984 & 47.0 \\
\hline P116-81-06 & S39.90690 & S39.90740 & E174.00539 & E174.50182 & 101 & 1799 & 42.4 \\
\hline P116-81-08 & S39.94161 & S39.94310 & E174.01151 & E174.50793 & 99 & 1796 & 42.4 \\
\hline P116-81-10 & S39.98670 & S39.98810 & E174.00627 & E174.50211 & 100 & 1794 & 42.3 \\
\hline P116-81-14 & S40.07360 & S40.07500 & E174.00595 & E174.50240 & 99 & 1793 & 42.3 \\
\hline P116-81-15 & S40.09800 & S40.09885 & E174.00664 & E174.36340 & 101 & 1318 & 30.4 \\
\hline P116-81-16 & S40.12070 & S40.12130 & E174.00931 & E174.50430 & 99 & 1787 & 42.2 \\
\hline P116-81-18 & S39.66208 & S40.16853 & E174.27260 & E174.27470 & 99 & 2347 & 56.3 \\
\hline P116-81-20 & S39.64560 & S40.17448 & E174.17780 & E174.17920 & 100 & 2449 & 58.8 \\
\hline P116-81-21 & S39.63988 & S40.16830 & E174.12640 & E174.12790 & 100 & 2447 & 58.8 \\
\hline P116-81-22 & S39.78670 & S40.17718 & E174.05402 & E174.05611 & 100 & 1834 & 43.4 \\
\hline P116-81-23 & S39.69024 & S39.69190 & E174.07899 & E174.33498 & 100 & 978 & 22.0 \\
\hline P116-81-24 & S39.74870 & S39.75008 & E174.07756 & E174.32458 & 99 & 946 & 21.1 \\
\hline P711 & S 37.37340 & S38.86797 & E172.07265 & E172.72943 & 21900 & 23600 & 175.9 \\
\hline P712 & S39.62329 & S39.67113 & E172.75381 & E173.33147 & 20008 & 20508 & 49.8 \\
\hline P713 & S38.60131 & S39.20576 & E171.85065 & E171.88895 & 18000 & 18639 & 67.3 \\
\hline P713_PT1 & S37.63869 & S38.59604 & E171.87012 & E171.90459 & 16897 & 17994 & 106.5 \\
\hline PHM1 & S39.65714 & S39.81511 & E174.26727 & E174.45605 & 160 & 640 & 23.9 \\
\hline PHM2 & S39.68575 & S39.80249 & E174.17903 & E174.47858 & 1 & 579 & 28.6 \\
\hline PS11 & S39.96824 & S40.10171 & E172.06570 & E172.54581 & 1063 & 1272 & 43.5 \\
\hline PS12 & S40.42837 & S40.59679 & E172.19948 & E172.37215 & 1615 & 1728 & 23.8 \\
\hline PS13 & S40.49680 & S40.53929 & E172.13376 & E172.32430 & 1527 & 1614 & 16.8 \\
\hline PS16 & S 40.21612 & S40.57861 & E172.14388 & E172.53848 & 1275 & 1526 & 52.4 \\
\hline PS18 & S40.33427 & S40.49475 & E172.90411 & E173.06032 & 840 & 951 & 22.3 \\
\hline PS26 & S40.42589 & S40.61018 & E173.53291 & E173.71550 & 200 & 328 & 25.6 \\
\hline PS27 & S40.43688 & S40.50820 & E173.41541 & E173.66754 & 329 & 443 & 22.8 \\
\hline S74-1 & S39.80054 & S39.96625 & E172.02660 & E172.20313 & 19 & 981 & 23.8 \\
\hline
\end{tabular}


37

\begin{tabular}{|c|c|c|c|c|c|c|c|}
\hline S74-10 & $S 40.04108$ & S40.23110 & E172.01039 & E172.72820 & 0 & 2620 & 64.6 \\
\hline S74-11 & S40.07034 & S40.36980 & E172.27319 & E172.59171 & 0 & 1737 & 42.9 \\
\hline S74-13 & S40.04697 & S40.31670 & E172.49879 & E172.72984 & 0 & 1449 & 35.8 \\
\hline S74-14 & S40.13789 & S40.28130 & E172.00522 & E172.55930 & 0 & 2019 & 49.7 \\
\hline S74-18 & S 40.22328 & S40.29680 & E172.00682 & E172.25620 & 0 & 919 & 22.7 \\
\hline S74-20 & S 40.30523 & S40.36520 & E172.10384 & E172.31850 & 0 & 783 & 19.4 \\
\hline S74-3 & S39.83123 & S 40.14620 & E172.00830 & E172.33759 & 0 & 1821 & 44.9 \\
\hline S74-4 & S39.84937 & S40.00687 & E171.99554 & E172.54793 & 59 & 2098 & 50.3 \\
\hline S74-5 & S39.87549 & S40.26930 & E172.01289 & E172.42770 & 0 & 2281 & 56.3 \\
\hline S74-7 & S39.89537 & S40.30882 & E172.11330 & E172.54800 & 38 & 2431 & 59.1 \\
\hline S74-9 & S39.99514 & S 40.36660 & E172.17210 & E172.55811 & 0 & 2142 & 52.8 \\
\hline SK10 & S39.82390 & S39.82720 & E174.10440 & E174.44727 & 1250 & 1839 & 29.3 \\
\hline SK12X & S39.73712 & S39.90510 & E174.23914 & E174.24382 & 504 & 885 & 18.6 \\
\hline TNZ-601 & S39.87990 & S39.88079 & E172.98912 & E173.36650 & 100 & 1392 & 32.2 \\
\hline TNZ-607 & S39.96132 & S39.96190 & E172.99780 & E173.37650 & 99 & 1390 & 32.2 \\
\hline TNZ-608 & S39.85119 & S40.24720 & E173.22221 & E173.22290 & 100 & 1858 & 44.0 \\
\hline TNZ-614 & S39.85939 & S40.01530 & E173.27060 & E173.27130 & 108. & 800 & 17.2 \\
\hline TNZ-614A & S40.00380 & S40.25446 & E173.27130 & E173.27240 & $750^{\circ}$ & 1864 & 28.0 \\
\hline TNZ-618 & S39.64350 & S 40.25462 & E173.30980 & E173.31293 & 100 & 2816 & 68.0 \\
\hline TNZ-619 & S40.03920 & S40.03980 & E172.99564 & E173.36710 & 100 & 1366 & 31.7 \\
\hline TNZ-622 & S39.85200 & $S 40.24702$ & E173.34520 & E173.34750 & 99 & 1850 & 43.9 \\
\hline TNZ-624 & S39.74460 & $S 40.25150$ & E173.02890 & E173.03149 & 100 & 2350 & 56.4 \\
\hline TNZ-626 & S39.74738 & S40.25363 & E173.11650 & E173.11769 & 99 & 2347 & 56.3 \\
\hline TNZ-630A & S39.74675 & S39.82370 & E173.19389 & E173.31006 & 99 & 623 & 13.1 \\
\hline TNZ-630AEX & S39.82756 & S39.95195 & E173.31577 & E173.50526 & 649 & 1499 & 21.3 \\
\hline TNZ-631 & $S 40.12020$ & S40.12159 & E172.99831 & E173.34381 & 100 & 1281 & 29.3 \\
\hline TNZ-641 & S40.19966 & S40.20110 & E172.99483 & E173.36780 & 100 & 1370 & 31.7 \\
\hline TNZ-645 & S39.75532 & S39.90700 & E172.99800 & E173.19289 & 100 & 1048 & 23.7 \\
\hline TNZ-645DL & S39.65696 & S39.74707 & E173.20374 & E173.33002 & 121 & 710 & 14.8 \\
\hline TNZ-647A & S39.67510 & S39.79877 & E173.36749 & E173.50270 & 100 & 819 & 18.1 \\
\hline TNZ-649 & S39.75610 & S39.90253 & E173.34389 & E173.50990 & 162 & 1025 & 21.6 \\
\hline TNZ-651 & S39.84550 & S39.99388 & E173.33118 & E173.50290 & 100 & 983 & 22.0 \\
\hline UM10 & S38.92233 & S38.92295 & E174.24651 & E174.44035 & 75 & 239 & 16.7 \\
\hline UM11/9 & S38.66926 & S38.87714 & E174.48602 & E174.58449 & 718 & 954 & 24.6 \\
\hline UM11/9 & S38.87057 & S38.96388 & E174.38463 & E174.49728 & 943 & 1076 & 14.3 \\
\hline UM6 & S38.95755 & S38.96311 & E174.19981 & E174.39944 & 1082 & 1255 & 17.2 \\
\hline W83-1A & S40.47292 & S40.47569 & E172.36867 & E172.94093 & 249 & 2190 & 48.4 \\
\hline W83-1B & S40.38554 & S40.50768 & E173.75662 & E173.76501 & 0 & 547 & 13.4 \\
\hline W83-1C & S40.64494 & S40.84645 & E173.69734 & E173.70227 & 1 & 899 & 22.4 \\
\hline W83-2A & S40.41347 & S 40.41682 & E172.58133 & E173.00748 & 4 & 1449 & 36.1 \\
\hline W83-2B & S40.30536 & S40.50237 & E173.70874 & E173.71637 & 0 & 882 & 21.9 \\
\hline W83-2C & S40.63223 & S40.86588 & E173.63983 & E173.65096 & 0 & 1040 & 26.1 \\
\hline W83-3A & S40.27794 & S40.35704 & E172.89638 & E173.08623 & 0 & 738 & 18.3 \\
\hline W83-3B & S40.33549 & S40.50274 & E173.66402 & E173.66769 & 0 & 748 & 18.6 \\
\hline W83-3C & S40.63076 & S40.85255 & E173.59831 & E173.60234 & 50 & 1037 & 24.7 \\
\hline W83-4A & S40.24604 & S40.48261 & E172.81815 & E173.04147 & 0 & 1299 & 32.5 \\
\hline
\end{tabular}


38

\begin{tabular}{|c|c|c|c|c|c|c|c|}
\hline W83-4B & S40.42418 & S40.42477 & E173.62981 & E173.84558 & 1 & 737 & \\
\hline W83-4C & S40.64969 & S40.78733 & E173.04533 & E173.20000 & 2 & 809 & \\
\hline W83-5A & S40.23212 & S40.47980 & E172.72141 & E172.97223 & -1 & 1394 & \\
\hline W83-5B & S40.45590 & S40.45638 & E173.61858 & E173.83214 & 1 & 728 & \\
\hline W83-5C & S40.65704 & S40.80518 & E173.12720 & E173.28307 & 2 & 845 & \\
\hline W83-6A & S40.31385 & S40.55944 & E172.51918 & E172.77528 & 2 & 1398 & \\
\hline W83-6C & S40.66001 & S40.76841 & E173.02614 & E173.38153 & 0 & 1297 & \\
\hline W83-7C & S40.64818 & S40.80876 & E173.17867 & E173.74803 & 0 & 2049 & \\
\hline W83-8C & S40.70151 & S40.77592 & E173.52718 & E173.77551 & 0 & 901 & \\
\hline W83-9C & $S 40.64162$ & S40.71871 & E173.55658 & E173.81227 & 0 & 930 & \\
\hline WM1 & S40.08953 & S40.09037 & E172.56070 & E172.70976 & 23463 & 23717 & \\
\hline WM100 & S39.31056 & S39.52280 & E172.90204 & E173.06569 & 9408 & 10138 & \\
\hline WM101 & S39.46432 & S39.46503 & E172.87575 & E173.00616 & 8483 & 8708 & \\
\hline WM11 & S39.64270 & S39.64320 & E172.39128 & E172.64841 & 19858 & 20299 & 21.9 \\
\hline WM11X & S39.64243 & S39.64660 & E172.62282 & E172.75710 & 10300 & 10529 & 11.5 \\
\hline WM13/1 & S39.55340 & S39.55400 & E172.39970 & E172.80779 & 18499 & 19200 & 35.0 \\
\hline WM13/2 & S39.55317 & S39.55447 & E172.80928 & E173.22731 & 5876. & 6596 & 35.9 \\
\hline WM14/0 & S39.50850 & S39.50930 & E172.41141 & E172.81860 & $17750^{\circ}$ & 18450 & 34.9 \\
\hline WM14/1 & S39.50790 & S39.50880 & E171.98660 & E172.39438 & 9849 & 10550 & 35.0 \\
\hline WM14/3 & S39.50741 & S39.50977 & E172.81131 & E173.17490 & 5250 & 5873 & 31.2 \\
\hline WM15/0 & S39.41710 & S39.41829 & E172.40070 & E172.80721 & 17000 & 17700 & 34.9 \\
\hline WM15/1 & $S 39.41600$ & S39.41730 & E172.81947 & E173.22549 & 9100 & 9799 & 34.9 \\
\hline WM16 & S39.37160 & S39.37230 & E172.82060 & E173.16814 & 6952 & 7550 & 30.0 \\
\hline WM17 & S39.27231 & S39.27590 & E172.39798 & E172.80368 & 15499 & 16199 & 34.9 \\
\hline WM18/0 & S39.22750 & S39.22785 & E172.42931 & E172.90842 & 14650 & 15477 & 41.3 \\
\hline WM18/1 & S39.22780 & S39.22820 & E172.90210 & E173.17957 & 8600 & 9079 & 23.8 \\
\hline WM19/0 & S39.18240 & S39.18260 & E172.33328 & E172.82471 & 13750 & 14599 & 42.4 \\
\hline WM19/1 & S39.18250 & S39.18288 & E172.80338 & E173.17331 & 7910 & 8549 & 31.9 \\
\hline WM19/2 & S39.18270 & S39.18290 & E171.98650 & E172.33322 & 4051 & 4650 & 29.9 \\
\hline WM2 & S40.04488 & S40.04520 & E172.52222 & E172.71918 & 26423 & 26759 & 16.8 \\
\hline WM20/0 & S39.13570 & S39.13810 & E172.40460 & E172.86740 & 12900 & 13700 & 39.9 \\
\hline WM20/1 & S39.13390 & S39.13560 & E172.86713 & E173.18292 & 7353 & 7899 & 27.2 \\
\hline WM21/0 & S39.09117 & S39.09400 & E172.38908 & E172.82521 & 28895 & 29649 & 37.7 \\
\hline WM21/1 & S39.08878 & S39.09140 & E172.80266 & E173.17819 & 6699 & 7348 & 32.5 \\
\hline WM22 & S38.99490 & S38.99900 & E172.40790 & E173.18750 & $1500^{\circ}$ & 2850 & 67.4 \\
\hline WM23 & S38.94518 & S38.94979 & E172.39708 & E173.17001 & 2860 & 4199 & 66.9 \\
\hline WM24 & S38.90000 & S38.90050 & E172.01248 & E172.59492 & 4701 & 5711 & 50.5 \\
\hline WM25 & S38.84469 & S38.84840 & E172.57518 & E173.18173 & 3451 & 4503 & 52.6 \\
\hline WM26 & S38.79216 & S38.79662 & E172.63284 & E173.18669 & 5722 & 6685 & 48.0 \\
\hline WM27 & S38.69500 & S38.70050 & E172.68138 & E173.16969 & 900 & 1749 & 42.4 \\
\hline WM28 & S39.79900 & S39.80021 & E172.62698 & E172.89578 & 10991 & 11449 & 22.9 \\
\hline WM3 & S39.99926 & S40.00099 & E172.50644 & E172.81909 & 25885 & 26419 & 26.7 \\
\hline WM4 & S39.95450 & S39.95470 & E172.57266 & E172.89059 & 25336 & 25879 & 27.2 \\
\hline WM5 & S39.90849 & S39.91170 & E172.49257 & E172.87750 & 24675 & 25334 & 32.9 \\
\hline WM51/1 & S39.40336 & S39.55891 & E173.16534 & E173.16719 & 6608 & 6949 & 17.2 \\
\hline WM51/2 & S38.65042 & S39.42015 & E173.16560 & E173.16690 & 3683 & 5390 & 85.6 \\
\hline
\end{tabular}


39

\begin{tabular}{|c|c|c|c|c|c|c|c|}
\hline WM53/0 & S38.78479 & S39.01064 & E173.05130 & E173.05180 & 1867 & 2368 & \\
\hline WM53/1 & S39.01120 & S39.23624 & E173.05142 & E173.05190 & 6250 & 6749 & \\
\hline WM53/2 & S38.66440 & S38.77710 & E173.04930 & E173.04950 & 4250 & 4500 & \\
\hline WM55/1 & S38.67520 & S39.23850 & E172.87070 & E172.87180 & 8100 & 9350 & \\
\hline WM55S & S39.77180 & S39.97109 & E172.87012 & E172.87224 & 27304 & 27746 & \\
\hline WM57/0 & S38.99805 & $S 40.00450$ & E172.75430 & E172.75610 & 0 & 2233 & \\
\hline WM57/1 & S38.66190 & S39.00804 & E172.75400 & E172.75439 & 4682 & 5450 & \\
\hline WM58 & S39.76984 & S40.10355 & E172.69826 & E172.70117 & 3528 & 4269 & \\
\hline WM59/0 & S39.00410 & S40.09452 & E172.63470 & E172.64259 & 4279 & 6700 & \\
\hline WM59/1 & S38.78070 & S39.00565 & E172.63879 & E172.63960 & 1850 & 2349 & \\
\hline WM61 & S39.09350 & S40.10780 & E172.52480 & E172.53310 & 6750 & 9000 & \\
\hline WM61/1 & S38.88520 & S39.06500 & E172.52370 & E172.52409 & 2450 & 2850 & \\
\hline WM63/0 & S39.02750 & S39.16280 & E172.41060 & E172.41130 & 9100 & 9400 & \\
\hline WM63/1 & S39.18430 & S39.88290 & E172.41090 & E172.41290 & 11300 & 12850 & \\
\hline WM63/2 & S38.67310 & S39.03360 & E172.40919 & E172.41098 & 3200 & 4000 & \\
\hline WM64 & S38.66085 & S39.82350 & E172.19749 & E172.20245 & 570 & 3151 & 129 \\
\hline WM7E & S39.82050 & S39.82380 & E172.65649 & E173.21062 & 21200 . & 22149 & 47 \\
\hline WM7W & S39.82020 & S39.82190 & E172.19250 & E172.54233 & $22601^{\circ}$ & 23200 & 30 \\
\hline WM8W & S39.77726 & S39.77872 & E172.40511 & E172.54698 & 23218 & 23462 & 12 \\
\hline WM9 & S39.73260 & S39.73309 & E172.40521 & E172.66124 & 20759 & 21198 & 21 . \\
\hline WM9X & S39.73153 & S39.73290 & E172.63829 & E172.76787 & 10764 & 10989 & \\
\hline
\end{tabular}

Onshore Seismic Reflection Profiles used in this study

\begin{tabular}{|c|c|c|c|c|c|c|c|}
\hline LINENAME & MINLAT & MAXIAT & MINLONG & MAXLONG & MINPT & MAXPT & LEN \\
\hline $78-03$ & S39.05382 & S39.13750 & E174.30141 & E174.46339 & 60 & 448 & 16.7 \\
\hline $78-05$ & S38.98877 & S39.04384 & E174.31294 & E174.33553 & 109 & 239 & 6.6 \\
\hline $78-11$ & S39.21260 & S39.22368 & E174.28329 & E174.37181 & 70 & 399 & 7.7 \\
\hline $78-11 X$ & S39.22020 & S39.28130 & E174.18021 & E174.27617 & 60 & 498 & 10.6 \\
\hline $78-15$ & S39.38570 & S39.39230 & E174.39371 & E174.42128 & 399 & 502 & 2.2 \\
\hline $78-15$ & S39.38582 & S39.39784 & E174.30150 & E174.38472 & 60 & 368 & 7.3 \\
\hline $78-16$ & S39.36280 & S39.36710 & E174.26450 & E174.39650 & 60 & 290 & 11.5 \\
\hline $78-17$ & S39.22831 & S39.26818 & E174.42253 & E174.54372 & 269 & 778 & 11.5 \\
\hline $78-17$ & S39.26840 & S39.27497 & E174.36960 & E174.41200 & 70 & 230 & 4.4 \\
\hline $78-18$ & S39.15829 & S39.17044 & E174.25362 & E174.41138 & 59 & 658 & 13.6 \\
\hline $78-18$ & S39.16122 & S39.16279 & E174.43933 & E174.46443 & 759 & 848 & 2.2 \\
\hline $78-20$ & S39.36249 & S39.38722 & E174.14566 & E174.26642 & 59 & 498 & 10.6 \\
\hline $78-21$ & S39.41705 & $\$ 39.46032$ & E173.86975 & E174.35091 & 70 & 919 & 41.6 \\
\hline $78-22$ & S39.35046 & S39.44023 & E174.15631 & E174.18402 & 69 & 489 & 9.9 \\
\hline $78-24$ & S39.31001 & S39.34168 & E174.12653 & E174.40230 & 69 & 1062 & 23.9 \\
\hline $78-30$ & S38.94700 & S38.98596 & E174.42644 & E174.52910 & 146 & 593 & 9.6 \\
\hline $78-30$ & S38.98694 & S38.99135 & E174.40569 & E174.41873 & 69 & 119 & 0.1 \\
\hline $78-34$ & S39.13772 & S39.24695 & E174.11014 & E174.14693 & 100 & 616 & 12.5 \\
\hline $78-35$ & S39.23075 & S39.32355 & E174.24107 & E174.27728 & 789 & 1220 & 10.8 \\
\hline
\end{tabular}




\section{7}

40

\begin{tabular}{|c|c|c|c|c|c|c|c|}
\hline $78-35$ & S39.28378 & S39.38320 & E174.26231 & E174.29860 & 60 & 521 & 11.5 \\
\hline $78-44$ & S39.34351 & S39.38831 & E174.40053 & E174.46761 & 239 & 563 & 7.3 \\
\hline $78-46$ & S39.30929 & S39.39768 & E174.32556 & E174.35030 & 49 & 468 & 9.9 \\
\hline $79-49$ & S39.13781 & S39.20326 & E174.37811 & E174.39378 & 79 & 399 & 7.7 \\
\hline $79-49$ & \$39.20735 & S39.21130 & E174.39995 & E174.42162 & 427 & 509 & 2.2 \\
\hline $79-57$ & S39.14750 & S39.22158 & E174.14684 & E174.25031 & 69 & 560 & 12.1 \\
\hline $79-62$ & S39.12958 & S39.16479 & E174.46526 & E174.57039 & 119 & 551 & 9.6 \\
\hline $79-69$ & S39.25489 & S39.27414 & E174.34180 & E174.39490 & 69 & 310 & 4.4 \\
\hline A & S39.50368 & S39.50497 & E174.13858 & E174.19968 & 1 & 45 & 5.0 \\
\hline AR-84-10 & S39.31557 & S39.41391 & E174.36676 & E174.37152 & 109 & 547 & 10.8 \\
\hline AR-84-11 & S39.30569 & S39.41189 & E174.30141 & E174.30432 & 110 & 583 & 11.9 \\
\hline C & S39.46397 & S39.46445 & E174.16693 & E174.24669 & 1 & 58 & 7.0 \\
\hline D & S39.41084 & S39.54210 & E174.16322 & E174.16849 & 0 & 120 & 14.6 \\
\hline HZT-111 & S39.45760 & S39.48980 & E173.87334 & E173.92688 & 151 & 297 & 5.4 \\
\hline HZT-115 & S39.40643 & S39.44282 & E173.81448 & E173.88304 & 191 & 370 & 7.0 \\
\hline HZT-115A & S39.44903 & S39.47313 & E173.89476 & E173.93744 & 400 & 514 & 4.4 \\
\hline HZT-116 & S39.26364 & S39.31338 & E173.80893 & E173.85057 & 300 . & 465 & 6.3 \\
\hline HZT-119 & S39.36433 & S39.42764 & E173.77625 & E173.89444 & $148^{\circ}$ & 458 & 12.3 \\
\hline HZT-119A & S39.43527 & S39.45747 & E173.90794 & E173.94737 & 494 & 599 & 3.9 \\
\hline HZT-123 & S39.34222 & S39.41122 & E173.77269 & E173.90468 & 148 & 492 & 14.0 \\
\hline HZT-123A & S39.54900 & S39.58520 & E174.17650 & E174.24396 & 130 & 483 & 7.0 \\
\hline HZT-124 & S39.43216 & S39.49170 & E173.95245 & E174.07561 & 131 & 444 & 12.5 \\
\hline HZT-127 & S39.31380 & S39.40567 & E173.76155 & E173.93541 & 146 & 600 & 18.1 \\
\hline HZT-128 & S39.24718 & S39.40089 & E173.82011 & E173.95050 & 170 & 682 & 20.4 \\
\hline HZT-131 & S39.31528 & S39.38276 & E173.80672 & E173.93456 & 184 & 518 & 13.4 \\
\hline HZT-132 & S39.29142 & S39.41476 & E173.83168 & E173.94278 & 153 & 572 & 16.5 \\
\hline HZT-135 & S39.26964 & S39.37120 & E173.76123 & E173.95082 & 199 & 697 & 19.8 \\
\hline HZT-136 & S39.30394 & S39.43325 & E173.84459 & E173.95100 & 184 & 611 & 16.9 \\
\hline HZT-139 & S39.28001 & S39.36211 & E173.81868 & E173.97050 & 279 & 679 & 16.1 \\
\hline HZT-143 & S39.23574 & S39.32774 & E173.77817 & E173.95000 & 155 & 605 & 18.1 \\
\hline HZT-146 & S39.43190 & S39.48109 & E173.87889 & E173.92630 & 175 & 346 & 7.0 \\
\hline HZT-150 & S39.42973 & S39.49853 & E173.89989 & E173.96338 & 360 & 595 & 9.4 \\
\hline HZT-151 & S39.20297 & S39.27984 & E173.79434 & E173.94200 & 159 & 541 & 15.3 \\
\hline HZT-159 & S39.17801 & S39.25302 & E173.84509 & E173.95128 & 189 & 498 & 12.3 \\
\hline HZT-164 & S39.43284 & S39.48853 & E173.99927 & E174.04001 & $179^{\circ}$ & 358 & 6.6 \\
\hline HZT-170 & S39.42665 & S39.50248 & E174.02258 & E174.07431 & 359 & 598 & 9.4 \\
\hline $\mathrm{KM}-1$ & S39.10060 & S39.11924 & E174.13507 & E174.22592 & 90 & 294 & 8.3 \\
\hline $\mathrm{KM}-2$ & S39.14077 & S39.14288 & E174.07687 & E174.20851 & 99 & 384 & 11.3 \\
\hline $\mathrm{KM}-3$ & S39.15184 & S39.18706 & E174.08197 & E174.19475 & 99 & 363 & 10.8 \\
\hline KM-6 & S39.14450 & S39.24838 & E174.11281 & E174.16609 & 79 & 391 & 12.5 \\
\hline $\mathrm{KM}-7$ & S39.13601 & S39.24017 & E174.13756 & E174.18869 & 80 & 392 & 12.1 \\
\hline KM-83-3 & S39.10283 & S39.18277 & E174.10272 & E174.14267 & 80 & 319 & 9.4 \\
\hline KM-9 & S39.09406 & S39.19855 & E174.15645 & E174.20982 & 90 & 403 & 12.7 \\
\hline M & S39.44833 & S39.52350 & E174.19958 & E174.20341 & 2 & 169 & 8.3 \\
\hline MK-07 & S39.04081 & S39.08245 & E174.26564 & E174.34535 & 79 & 287 & 8.6 \\
\hline MK-08 & S39.06424 & S39.12103 & E174.26711 & E174.36009 & 79 & 335 & 9.9 \\
\hline
\end{tabular}


268

41

\begin{tabular}{|c|c|c|c|c|c|c|c|}
\hline MK-13 & S39.13131 & S39.16414 & E174.28050 & E174.34578 & 80 & 249 & 7.0 \\
\hline MK-26 & S39.21456 & S39.21871 & E174.13788 & E174.36035 & 79 & 560 & 19.2 \\
\hline MK-26 & S39.21564 & S39.21618 & E174.36497 & E174.40247 & 570 & 651 & 3.2 \\
\hline MK-30 & S39.24936 & S39.25292 & E174.17943 & E174.36676 & 79 & 485 & 16.2 \\
\hline $\mathrm{MK}-30$ & S39.24941 & S39.25231 & E174.37601 & E174.42719 & 505 & 616 & 4.4 \\
\hline MK-33 & S39.28436 & S39.28612 & E174.38847 & E174.44630 & 90 & 215 & 4.4 \\
\hline MK-33 & S39.28475 & S39.28884 & E174.18964 & E174.36533 & 265 & 646 & 15.1 \\
\hline MK-35 & S39.30194 & S39.30481 & E174.40050 & E174.44698 & 74 & 175 & 3.9 \\
\hline MK-35 & S39.30326 & S39.30797 & E174.28667 & E174.39172 & 194 & 422 & 9.1 \\
\hline MK-36 & S39.24568 & S39.32339 & E174.19151 & E174.22646 & 75 & 304 & 9.1 \\
\hline $\mathrm{MK}-42$ & S39.02519 & S39.07005 & E174.31920 & E174.41167 & 40 & 278 & 9.4 \\
\hline MK-74 & S39.00578 & S39.04247 & E174.31888 & E174.39738 & 100 & 299 & 8.0 \\
\hline MK-76 & S38.99208 & S39.07583 & E174.30905 & E174.37926 & 80 & 358 & 11.3 \\
\hline MK-77 & S38.99965 & S39.14859 & E174.20601 & E174.34416 & 79 & 590 & 20.6 \\
\hline MT-84-10 & S39.09247 & S39.19509 & E174.33217 & E174.33344 & 110 & 566 & 11.3 \\
\hline $\mathrm{N}$ & S39.52095 & S39.52140 & E174.15132 & E174.20703 & 2 & 99 & 5.4 \\
\hline NK-06 & S39.39208 & S39.43404 & E174.15755 & E174.25211 & 81 & 466 & 9.6 \\
\hline OK-83-07 & S39.09911 & S39.16990 & E174.00647 & E174.16333 & 72 & 465 & 15.6 \\
\hline $\mathrm{PH}-02$ & S39.51567 & S39.52418 & E174.29247 & E174.37347 & 9 & 247 & 7.0 \\
\hline PH-03 & S39.42480 & S39.42850 & E174.32680 & E174.38010 & 10 & 160 & 4.4 \\
\hline $\mathrm{PH}-03$ & S39.42930 & S39.43290 & E174.39070 & E174.44389 & 190 & 340 & 4.4 \\
\hline PR83-01 & S39.50356 & S39.51345 & E174.39140 & E174.42772 & 79 & 219 & 3.2 \\
\hline PR83-01 & S39.51540 & S39.60950 & E174.26830 & E174.37440 & 280 & 800 & 13.8 \\
\hline PR83-02 & S39.59244 & S39.62394 & E174.26625 & E174.35965 & 110 & 405 & 8.3 \\
\hline PR83-02 & S39.62980 & S39.71194 & E174.36766 & E174.45332 & 440 & 872 & 11.7 \\
\hline PR83-03 & S39.56071 & S39.58060 & E174.29214 & E174.36095 & 109 & 340 & 6.3 \\
\hline PR83-03 & S39.58155 & S39.59821 & E174.36697 & E174.39557 & 359 & 476 & 2.2 \\
\hline PR83-04 & S39.55637 & S39.56838 & E174.41724 & E174.46124 & 190 & 349 & 3.9 \\
\hline PR83-05A & S39.48452 & S39.52065 & E174.36824 & E174.37392 & 1150 & 1308 & 3.2 \\
\hline PR83-05B & S39.47350 & S39.47748 & E174.41060 & E174.41811 & 1000 & 1030 & 0.1 \\
\hline PR83-05B & S39.47940 & S39.48820 & E174.36978 & E174.40495 & 1050 & 1168 & 2.2 \\
\hline PR83-11 & S39.55547 & S39.64548 & E174.37460 & E174.41211 & 179 & 579 & 10.6 \\
\hline ST-83-1 & S39.29142 & S39.39342 & E174.23155 & E174.29756 & 80 & 400 & 12.7 \\
\hline ST-83-3 & S39.29692 & S39.32286 & E174.20541 & E174.38664 & 139 & 537 & 15.9 \\
\hline ST-83-3 & S39.32403 & S39.32648 & E174.39534 & E174.41409 & 79 & 120 & 2.2 \\
\hline TP-01 & S38.99615 & S39.03160 & E174.36800 & E174.41730 & 9 & 250 & 5.9 \\
\hline TP-09 & \$39.31880 & S39.31921 & E174.40933 & E174.47729 & 709 & 950 & 5.4 \\
\hline TP-09 & S39.31940 & S39.32030 & E174.22043 & E174.38933 & 39 & 638 & 14.6 \\
\hline TV-83-01 & S39.06525 & S39.16500 & E174.03363 & E174.05403 & 170 & 514 & 11.3 \\
\hline TV-83-02 & S39.09974 & S39.16504 & E174.00348 & E174.03619 & 109 & 352 & 8.0 \\
\hline TV-83-03 & S39.11055 & S39.18391 & E173.97298 & E174.02919 & 169 & 450 & 9.6 \\
\hline TV-83-04 & S39.14333 & S39.21539 & E173.88853 & E173.97057 & 150 & 488 & 10.4 \\
\hline TV-83-05 & S39.14589 & S39.22561 & E173.87560 & E173.96423 & 108 & 505 & 11.7 \\
\hline TV-83-06 & S39.16165 & S39.23283 & E173.85565 & E173.93367 & 110 & 418 & 10.4 \\
\hline TV-83-07 & S39.19258 & S39.26183 & E173.80894 & E173.95493 & 109 & 549 & 14.5 \\
\hline TV-83-08 & S39.24841 & S39.27184 & E173.79839 & E173.91925 & 110 & 444 & 10.6 \\
\hline
\end{tabular}


42

$\begin{array}{llllllll}\text { TV-83-09 } & \text { S39.09553 } & \text { S39.26564 } & \text { E173.80962 } & \text { E174.00395 } & 100 & 949 & 25.3 \\ \text { TV-83-10 } & \text { S39.15822 } & \text { S39.28119 } & \text { E173.90419 } & \text { E174.05927 } & 110 & 839 & 19.1 \\ \text { WT-85-114 } & \text { S39.12422 } & \text { S39.33319 } & \text { E173.76909 } & \text { E173.93896 } & 110 & 1210 & 27.4 \\ \text { WT-85-126 } & \text { S39.18922 } & \text { S39.39942 } & \text { E173.78857 } & \text { E173.96933 } & 110 & 1234 & 28.0 \\ \text { WT-85-129 } & \text { S39.30058 } & \text { S39.43795 } & \text { E173.75888 } & \text { E174.01031 } & 110 & 1171 & 26.5 \\ \text { WT-85-139 } & \text { S39.25636 } & \text { S39.28595 } & \text { E173.77342 } & \text { E173.83194 } & 110 & 351 & 5.9\end{array}$


APPENDIX 3: WELLS USED (for time-depth data)

\begin{tabular}{|c|c|}
\hline Offshore & P.R. \\
\hline Ariki-1 & 1038 \\
\hline Awakino-1 & 1140 \\
\hline Cook-1 & 513 \\
\hline Fresne-1 & 674 \\
\hline Kiwa-1 & 880 \\
\hline Kongahu-1 & 1035 \\
\hline Kupe-1 & 662 \\
\hline Mangaa-1 & 554 \\
\hline Maui-1 & 540 \\
\hline Maui-3 & 541 \\
\hline Maui-2 & 541 \\
\hline Maui-4 & 943 \\
\hline Moa-1 & 402 \\
\hline Moki-1 & 987 \\
\hline North Tasman-1 & 736 \\
\hline Surville-1 & 677 \\
\hline Tahi-1 & 1030 \\
\hline Taimana-1 & 1026 \\
\hline Tane-1 & 698 \\
\hline Tangaroa-1 & 1038 \\
\hline Tasman-1 & 512 \\
\hline
\end{tabular}


Te Whatu-2

1345

Toropuihi-1

1288

Turi-1 659

Wainui-1 869

Witiora-1 1037

Onshore

Ahuroa-1

C. Farewell-1

Cape Egmont-1

Kaimiro-1

Kapuni Deep

Kapuni-2

Manganui-1

McKee-1

New Plymouth-2

Ngatoro-1

Onaero-1

Stratford-1

Tariki-1A

Te Kiri-1

Tipoka-1A

Toko-1

Totara-1 1260

P.R.

1234

1293

936

1024

464

911

786

457

1092

864

968

1248

1249

1294

761

1348 
Tuhua-1 979

Urenui-1 505

Waihapa-1,A,B 1187

Wharehuia-1 1181 


\section{APPENDIX 2}

Unpublished paleontological data referenced in the present study.

1. J.I. Raine 1991: Cape Farewell-1, revised palynology. 274

2. J.I. Raine 1991: Pakawau Group palynology. 278

3. G.J. Wilson 1991: Marine palynostratigraphy of the Pakawau Group. 279

4. G.J. Wilson 1991: Marine palynostratigraphy of Cook-1. 281 


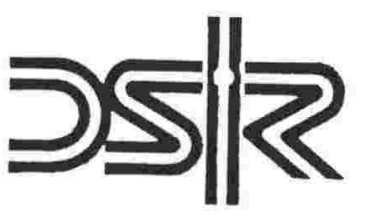

NEW ZEALAND

DEPARTMENT OF

SCIENTIFIC AND

INDUSTRIAI

RES EA R C R

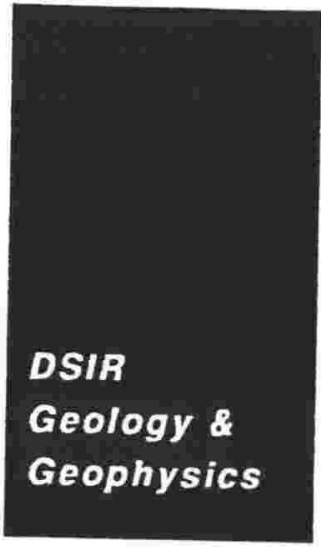

\section{DATE: $\quad 01-J U L-91$ \\ G. THRASHER \\ TO: \\ FROM: \\ J.I. RAINE}

GEO FILE NO: M24/774

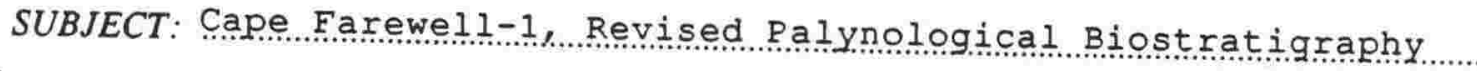

\section{MEMO}

\section{CAPE FAREWELL-1}

The well was spudded in Farewell Formation/Wharariki Formation, with a target of Late Cretaceous sandstone. Drill cuttings were collected every $10 \mathrm{~m}$ to T.D.; no sidewall or conventional cores were cut.

Palynostratigraphic study was carried out at the time of drilling by report. Cartoran Services Ltd. (Appendix $V$ in the well completion report, Carter \& Kintanar 1987). The highest sample for palynological sequence named the "Pillar Foterbedded sandstone-siltstone-mudst one shis unit (incle the "Pillar Formation" in the well completion report. This unit (included in the North Cape Formation of Thrasher 1990) Formation Formation (after Suggate 1956). Palynofloras reported by Haskell were accorded an Haumurian age. Underlying the Pillar Formation is the with reported ages of Rauk Formation" (the Rakopi Formation of Thrasher) Haumurian at top. No paukmara Series at base, through Piripauan, to drilled, the "Riley's Conglofloras were recovered from the lowest unit Thrasher). Palynological slides " (the Otimataura Conglomerate of Services Ltd alynological slides prepared by Haskell Exploration 1990).

$$
\text { New sampling and results }
$$

Sampling was concentrated in the lower part of the sequence, the top of the Rakopi Formation being located at about $1097 \mathrm{~m}$. Coal chips were isolated from cuttings samples containing abundant coal chips, corresponding to electric log indications of the presence of coal seams: this procedure helps to minimise the contribution of downhole (caved)

Results are summarised in Table 1, miospore species identified being listed in Table 2. <Tricolpites lilliei>, index species of the PM2 from the pupong occurs in all but the uppermost two samples, which are miom the Puponga and North Cape formations and contain only sparse miospore assemblages. There is no indication in the present work of <C-PM2 zones: such species as <Tricolpites sabulosus> and of zone PMI, were not recorded.
of 
Table 1. Summary of results, Cape Farewell-1

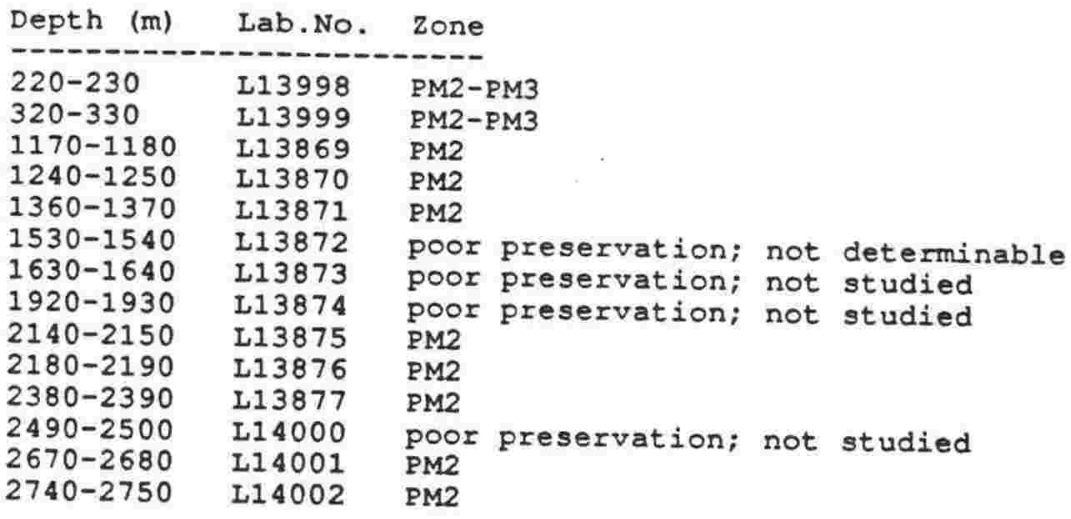

Haskell (in Carter \& Kintanar 1987) dated samples from 830, 900, 1000, $1140,1170,1240$ and $1360 \mathrm{~m}$ as Haumurian, noting that most taxa identified are longer-ranging forms. Samples from 1800 and $1960 \mathrm{~m}$ were dated as Piripauan on the basis of the occurrence of <Proteacidites scaboratus> and <Baculatisporites comaumensis> although Haskell observes that both species occur in the Haumurian Stage; the Piripauan determination appears to be based mainly on interpolation between Haumurian above and claimed Raukumara Series strata below. The basis for these older dates, from samples at $2070,2300 \mathrm{~m}$ must now be examined (lower samples at 2340 and $2800 \mathrm{~m}$ did not contain significant miospore assemblages). The age is based on the occurrence of <Osmundacidites wellmanil>, with a given upper range limit of Raukumara Series; <Cingutriletes clavus>, with a given upper range limit of early Late Cretaceous in Australia; and <Cyclosporites hughesii>, with an Australian range of Aptian-Albian. <0. wellmanii> is a species with poorly defined morphological and stratigraphic limits; I do not regard the Raukumara Series upper limit giveh in Raine (1984) as definitive. have recorded specimens similar to <C. clavus $>$ from zone PM2 in the Paparoa Coal Measures, Greymouth Coalfield. The most significant, and puzzling, species is <C. hughesii>. In New zealand, I have recorded it only from pre-Motuan Torlesse Supergroup (Raine et al. 1981), although Pocknall \& Lindqvist (1988) have illustrated two specimens from the Purseg (<Trichotomosulcites subgranulatus> Assemblage of Motuan-Mangaotanean age). I have examined both specimens: they lack the and and I regard them as representatives of <Lycopodiacidites>, perhaps <L. cristatus> Couper. Removing the New Zealand upper range limit of <C. hughesii> to an earlier epoch does not remove the apparent age discrepancy: rather it aggravates it. Since the specimen recorded by Haskell is compared to, rather than identified with <C. hughesii>, it is possible that a different taxon is involved. Alternatively, the

In conclusion, I regard the evidence for the presence of strata older than Zone PM2 as slight, and negated by more positive indications from the present study, particularly the presence of the index species of zone PM2, <Tricolpites lilliei>, as low as $2740-50 \mathrm{~m}$, only $67 \mathrm{~m}$ (measured along hole) above the base of the hole. 
Table 2. Miospores identified in cuttings samples, Cape Farewell-1

\begin{tabular}{rl} 
Ref. - & Depth (m) \\
\hline 1 & $220-230$ \\
2 & $320-330$ \\
3 & $1170-1180$ \\
4 & $1240-1250$ \\
5 & $1360-1370$ \\
6 & $2140-2150$ \\
7 & $2180-2190$ \\
8 & $2380-2390$ \\
9 & $2670-2680$ \\
10 & $2740-2750$
\end{tabular}

Group: POLLENITES

Araucariacites sp.

Beaupreaidites echinatus eraine: MS.

Microcachryidites antarcticus

Nothofagus cf. senectus

Nothofagus kaitangata

Nothofagus sp.

Phyllocladidites mawsonii

'Phyllocladidites' paleogenicus

Podocarpidites ohikaensis

Podocarpidites spp.

Proteacidites ?granoratus

Proteacidites palisadus

Proteacidites cf. subpalisadus

Proteacidites spp.

Trichotomosulcites subgranulatus

Tricolpites cf. fissilis

Tricolpites gillii

Tricolpites lilliei

Tricolpites pachyexinus

Tricolpites cf. phillipsii

Tricolpites striatus

Tricolpites waiparaensis

Tricolpites spp.

Tricolporites sp.

Triorites minor

Ref: - $\begin{array}{lllllllllll}1 & 2 & 3 & 4 & 5 & 6 & 7 & 8 & 9 & 10\end{array}$

Group: SPORITES

Baculatisporites comaumensis

Camarozonosporites sp.e eRaine: MS.

Camarozonosporites spp.

Cibotildites tuberculiformis

Cibotildites sp.

Clavifera triplex

Cyathidites minor

Cyathidites spp.

Gleicheniidites senonicus

Laevigatosporites major

Laevigatosporites ovatus

Leiotriletes sp.

Lycopodium cf. fastigioides

Lycopodiumsporites austroclavatidites

lycopodiunsporites sp.

Osmundacidites sp.

Peromonolites bowenii

Rubinella sp.

Stereisporites antiquasporites

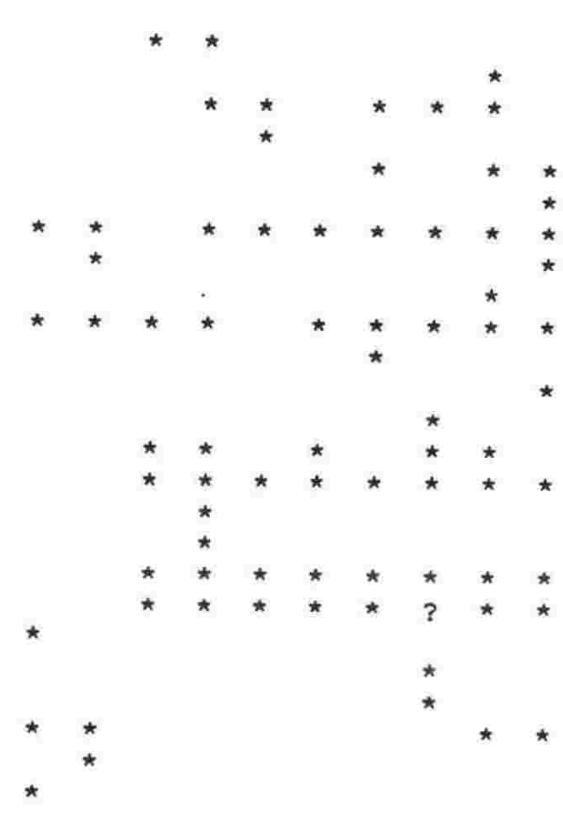


CARTER, M.; KINTANAR, E.R.I. 1987: Cape Farewell-1 well completion report. Petroleum Corporation of New Zealand (Exploration) Ltd. report no. 0362. Unpublished petroleum report PR 1234 held by New Zealand Geological Survey, Lower Hutt.

POCKNALL D,.T.; LINDQVIST, J.K. 1988: Palynology of Puysegur Group (Mid Cretaceous) at Gulches Peninsula, South Fiordland. <New zealand Geological Survey Record 35: 86-93.

RAINE, J.I. 1984: Outline of a palynological zonation of Cretaceous to Paleogene terrestrial sediments in West Coast Region, South Island, New zealand. <Report, New zealand Geological Survey $109 .>82$ p.

RAINE, J.I.; SPEDEN, I.G.; STRONG, C.P. 1981: New Zealand. Pp. 221-267 <In> REYMENT, R.A.; BENGTSON, P. (Eds). <Aspects of Mid-Cretaceous regional geology>. Academic Press, London.

SUGGATE, R.P. 1956: Puponga Coalfield. <New Zealand journal of science and technology $B 37(5):>539-559$.

THRASHER, G. 1990: Late Cretaceous sediments of Taranaki Basin. <Recent developments in New Zealand basin studies. Seminar sponsored by DSIR Geology \& Geophysics, 19 September 1990:> 13-14. 


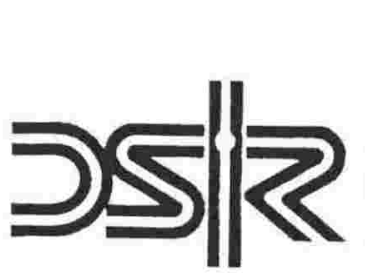

NEW ZEALAND

DEPARTMENT OF

SCIENTIFIC AND

INDUSTRIAL

RESEARCA
DATE:

27-JUN-91

TO:

FROM:

G. Thrasher

GEO FILE NO:
DSIR

Geology \& Geophysics 
YAFINE PALYNOSTFATIGRAFHY OF THE FAKRMAU GFOUP, NORTIREST NELSON

Graeme J. Wilson

Report GJW 218/91

File $N 25$

Taranati CCP

INTRODUCTION

July 1991

This report is additional to Report. IIR $3 / 91$ by J.I. Raire in which 6 outcrop samples collected by $G$. Thrasher and J. Collen from various Pakawa Group localities in the northern part of northwest Nelson were examined. Three of these were found to contain marine dinoflagellate
cysts.

\section{RESULTS}

Sample N25/f66 (II4E97) from Wairoa River mouth, near Rakopi/North Cape Formation contact, yielded a sparse poorly preserved assemblace of dinoflagellate cysts including Manumiella of cruggii, Alterbioinium cf acutulum, Vozzhennikovia spinulosa, Cassiculosphaeridia sp. Canningia sp. The palynomorph assembiage is dominated by terréstrially derived organic matter (not well preserved).

Sample M25/f68 (I14899) from Mangarakau Stream mouth, near base of the North Cape Fornation, yielded a sparse poorly preserved dinoflagellate assemblage with few complete identifiable specinens. Identifiable taxa include Microdinium of veligerum. Cassiculosphaeridia sp. , Cleistosphaeridium sp., Cerodinium sp.. Fibrocysta sp. Specimens of Crassosphaera (Prasinophyceae) were also observed. Terrestrially derivec organic matter is rare and poorly preserved.

Sample N.25/f69 (I14900) from "Dry Road", near base of North Cape Formation, yielced a moderately diverse poorly preserved dinoflagellate assemblage including Palaeocystodinium cf australinum. Manumiella cf drucGii, Vozzhennikovia spinulosa xiphophoridium cf alatum, and The palynomorph assemblage is dominated by terrestrially derived pollen, spores and plant material which is relatively well preserved.

\section{DISCUSSION}

All samples are apparently Late Haumurian and marginal marine, based on the dinoflagellate assemblages. The presence of Vozzhennikovia spinulcsa in $f 69$ suggests a pre-druggil assemblage which is likely

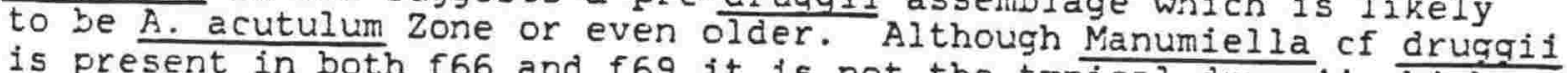
is present in both $f 66$ and $f 69$ it is not the typical drugaii which characterises uppermost $M$ as asemblages, and it may represent a slightly older Mh horizon. The precise age of $f 68$ is somewhat more difficult to determine although the presence of Microdinium of veligerum confirms an Mh age. Marine or marginal marine intervals in the Pakawau Group are known from off shore well data in widely separated areas of the

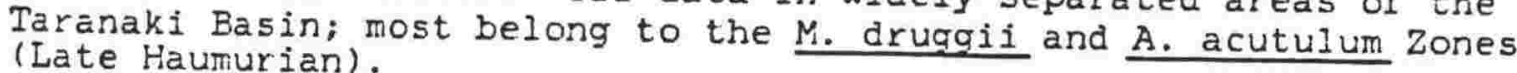



polien and plant material, but no marine pajynomorphs. The sample is much more mature and less well premphs but the organic matter higher energy environment.

The occurrence of dinoflagellates indicates marine conditions between $4860^{\prime}$ and $7270^{\prime}$ although their rarity points to marginal narine or broken fragmented nature suggestse conditions. Furthermore their is medium.

The age of the dinoflagellate cysts is Late Haumurian, with most zones. The first downhole Manumiella druggii and Alterbidinium acutulum and it is likely that the occurrence of $A$. acutulum is at $5920^{\prime}-5940^{\prime}$ above $5920^{\circ}$. The $A$. acutulum Zone is Zore extends from $4860^{\circ}$ to just the last downhole occurrence of the zone index at 7270 . present to it is noteworthy that several taxa typical of at $7270^{\prime}$. However occur also in the $\mathrm{A}$. acutulum Zone arid this of the $\mathrm{M}$. druggii Zone In any case the presence of the Late Haumurian probably due to caving. $2500^{\circ}$ of sediments indicates apparent rapian zones through some 
MARINE PALYNOSTRATITRAFHY OF NEW ZEALAND AOUITAINE PETROIEUM ITD COOK-1 WELL, SOUTHERN TARANAKI BASIN, 4300'-8730.

Graeme I. Wilson

\section{INTRODUCTION}

Report GJN $217 / 91$

File Cook-1

Taranaki CCP

July 1991

This report is additional to Report JIR $2 / 91$ by J.I. Raine in which 8 new samples were examined between $4620^{\circ}$ and $7270^{\circ}$. All are cuttings and these supplement the original sidewall samples examined by $W . F$. Harris. Most of the samples are from the "middle silty sandy sequence" from $4640^{\prime}$ to $7387^{\prime}$ between the upper and lower coaly sandy sequences. This interval was not originally examined for palynomorphs.

\section{RESULTS}

Sample Ll4856 from the base of the "upper coaly sandy sequence" yielded abundant pollen, spores and plant matter, but no dinoflagellate cysts
were observed.

All samples from the "middie silty sandy sequence" between $4860^{\circ}$ and $7270^{\circ}$ contain dinoflagellate cysts, although they are relatively rare and usually broken or poorly preserved.

At $4860^{\circ}-4880^{\circ}$ ( 214857 ) dinof lagellate cysts are extremely rare and incluce Fibrocysta sp. Manumiella sp., and Cribroperidinium cf. wetzeli. Preservation is poor.

The cuttings samples at 5000' (L24858) and 5440' (L14859) are dominated by terrestrially derived palynomorphs but both contain the cinoflagellate species Manumiella druggii and Fibrocysta bipolaris. The dinofiageliates are slightly more abundant in the lower sample.

At 5920'-5940' (L14860) dinoflagellates are more liverse (though still rarel and incluce Alterbidinium acutulum, M. druggii (very worn), Pyxidnopsis sp., Fibrocysta bipolaris, Diconodinium of. glabrum,
Palaevoystodinium golzowense.

At $6570^{\circ}-6580^{\circ}$ (L1486I) dinoflagellates are extremely rare and poorly preserved and represented by a single species, M. druggii.

At $6850^{\circ}-6860^{\circ}$ (Ll4682) dinoflagellates are mocterately diverse and include $F$. cf. bipolaris, M. druggii (very worn), Cordosphaeridium fibrospinosum, and Manunieila cf. seelandica.

The assemblage from $7260^{\circ}-7270^{\circ}$ ( $L 14863$ ) is fairly diverse and incluces M. druggii (broken), P. golzowense. Turbiosphaera cf. filosa, Alisocysta cf. reticulata, A. acutulum.

Samples from 7462' and below yielced poorly structured organic matter, spores and pollen, but no dinoflagellate cysts were recorded.

\section{DISCUSSION}

At $4300^{\circ}$ the organic matter contains abundant well preserved spores, 